

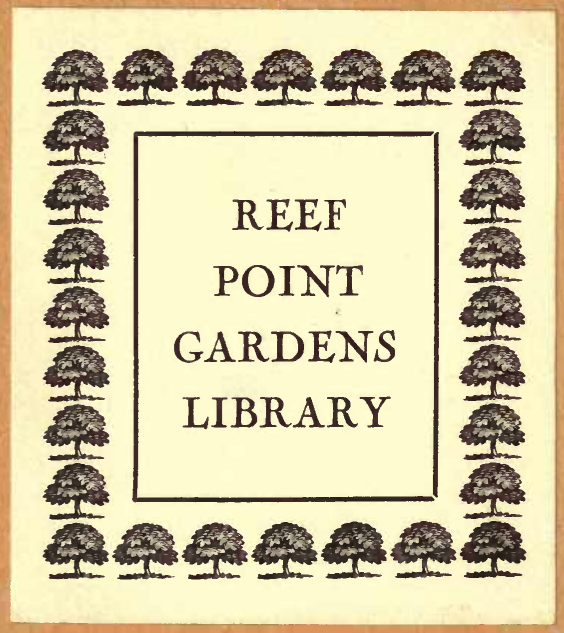

\section{The Gift of Beatrix Farrand} to the General Library University of California,Berkeley 


PUBLICATIONS OF THE ARNOLD ARBORETUM, NO. 4

\section{PLANTAE WILSONIANAE}

AN ENUMERATION OF THE WOODY PLANTS

COLLECTED IN WESTERN CHINA FOR THE

ARNOLD ARBORETUM OF HARVARD

UNIVERSITY DURING THE YEARS

1907, 1908, AND 1910

BY E. H. WILSON

EDITED BY

CHARLES SPRAGUE SARGENT

PART I

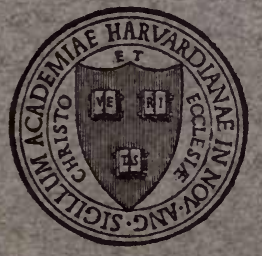

ISSUED, JULY 31,1911

CAMBRIDGE

THE UNIVERSITY PRESS 1911 
PLANTAE WILSONIANAE, PART I. ISSUED JULY 31, 1911

\section{Pinaceae}

Pinus by George R. Shaw ............... 1

SAXITRAGACEAE

Philadelphus by E. Koehne ............. 4

Deutzia by Alfred Rehder . . . . . . . . . . . 6

Cardiandra by Alfred Rehder . . . . . . . . . . 24

Hydrangea by Alfred Rehder . . . . . . . . . . 25

Schizophragma by Alfred Rehder ... . . . . . . 41

Dichroa by Alfred Rehder .............. 43

Itea by Alfred Rehder. . . . . . . . . . . . 44

Ribes by E. Janczewski ... . . . . . . . . . . 44

\section{ROSACEAE}

Sorbaria by Alfred Rehder . . . . . . . . . . 47

Rubus by W. O. Focke . . . . . . . . . . . . 48

Maddenia by E. Koehne . . . . . . . . . . . 56

Prunus Subgen, Padus by E. Koehne. . . . . . . 59

Aquifoliaceae by $\mathrm{Th}$. Loesener

Ilex . . . . . . . . . . . . . . 76

ACERACEAe by Alfred Rehder

Dipteronia . . . . . . . . . ..... 83

Acer ..................... 83

Vitaceae by F. Gagnepain

Tetrastigma . ...................... 99

Cayratia. ...................... 99

Ampelopsis .................... 100

Parthenocissus .................. 101

Vitis .................... 102

Caprifoliaceae by Alfred Rehder

Sambucus. . .................... 106

Viburnum. .................. 106

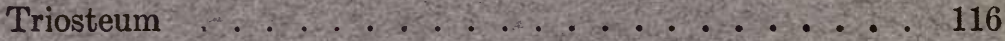

Symphoricarpos .................. 117

Dipelta . . . . . . . . . ....... 118

Abelia ..................... 118

Lonicera ................... . . 129

Diervilla ................. 144

\section{Add to tib.}

LANDSCAPE

ARCHITECTURE

Farrand Gift 


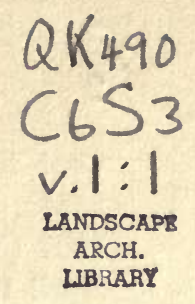

\title{
PINACEAE.
}

\author{
PINOS L. \\ Determined by George Rossell Shaw.
}

Pinus Armandii Franchet in Nouv. Arch. Mus. Paris, sér. 2, VII. 95, 96 t. 12 (Pl. David. I. 285) (1884).

Pinus scipioniformis Masters in Bull. Herb. Boissier, VI. 270 (1898).

Pinus koraiensis Masters in Gard. Chron. ser. 3, XXXIII. 34, f. 18, 19 (not Siebold \& Zuccarini) (1903).

Pinus Mastersiana Hayata in Gard. Chron. ser. 3, XLIII. 194 (1898).

Pinus Armandii, var. Mastersiana Hayata in Jour. Coll. Sci. Tokyo, XXV. art. XIX. 215, f. 8 (Fl. Mont. Formos.) (1908).

Western Hupeh: Sze-kou-tze, east of Hsing-shan Hsien, December 1907 (No. 2505); northwest of Hsing-shan Hsien, alt. 2000 m., September 1907 (No. 2506); Ta-wan, alt. 1500 m., June and July 1907 (No. 2509); Hsing-shan Hsien, July 1907 (No. 25II). Western Szech'uan: Wa-ssu country and mountains west of Wên-chuan Hsien, alt. 1500-2500 m., July and November 1908 (No. II5I); Feiyueh-ling, Ching-chi Hsien, alt. 2500-2800 m., August 1908 (No. 1387); Pan-lan-shan and Tachien-lu, alt. 2500-3300 m., June and November 1908 (No. I470).

Pinus Bungeana Zuccarini in Endlicher, Syn. Conif. 166 (1847).

Western Hupeh: Pa-tung Hsien, November 1907, January 1909 (No. 2512).

It is interesting that this species, originally described from cultivated plants near Pekin, was found by Mr. Wilson growing wild on the mountains of Hupeh.

Pinus Massoniana Lambert, Gen. Pin. I. 17, t. 12 (1803).

Western Hupeh: Hsing-shan Hsien, alt. 1300-1500 m., July 1907 and January 1909 (No. 1469); Ichang and vicinity, alt. 1000-1500 m., December 1907 (No. I480); alt. 1300 m., April and December 1907 (No. I48I); alt. up to 1300 m., May and December 1907 (No. 2503); Chang-yang Hsien, alt. 1500 m., November 1907 (No. I482). W estern Szech'uan: Wa-shan, alt. 1300 m., November 1908 (No. r378); alt. 1100-1500 m., September 1908 (No. 1476); Kia-ting and vicinity, 
west to Mupin, alt. up to 1000 m., May and November 1908 (No. 1468). Kiangsi: foot hills about Kiu-kiang, alt. 300 m., August 1907 (No. I744). Hongkong: Happy Valley, alt. sea-level-600 m., April 1909 (No. I483).

Pinus densiflora Siebold \& Zuccarini, Fl. Jap. II. 22, t. 112 (1842).

Pinus Henryi Masters in Jour. Linn. Soc. XXVI. 550 (1902).

Western Hupeh: Hsing-shan Hsien, July 1907 (No. I484); alt. 1300 m., May 1907 (No. I49o); alt. 1500 m., January 1908 (No. I495); alt. 1300 m., July 1907 (No. I497); alt. 1600 m., May 1907 (No. I498); alt. 1600 m., May 1907 (No. I499); Sheng-ting-chia, May 1907 (No. I496); Sze-kou-tze, east of Hsing-shan Hsien, alt. 1300-2000 m., December 1907, January 1908 (No. I485); Ma-fou-ling, west of Hsingshan Hsien, alt. 1500-2000 m., January 1908 (No. I486); alt. 1600 m., January 1908 (No. I487); Fang Hsien, alt. 1600-2500 m., May 1907 (Nos. I488, I494); Ta-wan, Patung Hsien, alt. 2200 m., May, July and December 1907 (No. I489); northwest of Hsing-shan Hsien, alt. 1600 m., January 1909 (No. r492). Kiangsi: Ku-ling, alt. 1500 m., July 1907 (No. I745); alt. 1400 m., August 1907 (No. I747).

Pinus yunnanensis, Franchet in Jour. de Bot. XIII. 253 (1899).

Western Szech'uan: Mupin and vicinity, alt. 1600-2300 m., November 1908 (No. I097); Wa-ssu country, Wên-chuan Hsien, alt. 1600-2300 m., November 1908 (Nos. 1369, 1370); 12 kilometers from Mupin, Yung-tsen, alt. 1300 m., November 1908 (No. r376); Mupin, alt. 1300-1600 m., November 1908 (Nos. I390, I395); alt. 1300-2000 m. (No. I399); alt. 1600 m. (No. I464); Nitou, Chin-chi Hsien, alt. 1500-1600 m., November 1908 (No. r393); Malie, Wa-shan, alt. 1600 m., November 1908 (No. I394); Tung Valley, alt. 1300-1600 m., November 1908 (No. I396); Wa-shan, alt. 1600 m., September 1908 (No. I47I); Mupin, alt. 1500-2000 m., November 1908 (No. I472); descent from Tachien-lu, alt. 2300 m., August 1908 (No. 250r).

Pinus densata Masters in Jour. Linn. Soc. XXXVII. 416 (1906).

Pinus prominens Masters in Jour. Linn. Soc. XXXVII. 417 (1906).

Western Szech'uan: Chito village, 16 kilometers west of Tachien-lu, alt. 3300 m., July 1908 (No. 905); Wa-ssu country, Wênchuan Hsien, alt. 1600-2300 m., November 1908 (No. I368); 20 kilometers north of Tachien-lu, alt. 2800-3300 m., October 1908 (No. r397); Tung Valley, alt. 1100 m., October 1908 (No. r398); Orang- 
che, Valley of Ya-lung, type locality, alt. 3000-3600 m., October 1908 (Nos. 1465, 1466, 1467, 1478); alt. $4000 \mathrm{~m}$. (No. 1479); forests of Ta-pao-shan, northeast of Tachien-lu, alt. 3500 m., July 1908 (No. I49I); descent of Hsao-chin-ho, Mou-kong-ting, alt. 2300-2600 m., June 1908 (No. I500); north of Tachien-lu, alt. 3300 m., July 1908 (No. 2502); Moshi mien, southeast of Tachien-lu, alt. 1600-2000 m., October 1908 (No. 2504); Sung-pan, alt. 2600-3000 m., 1910 (No. 4055); no locality, 1910 (No. 4073).

\section{Pinus Wilsonii Shaw, n. sp.}

Arbor excelsa foliis geminis rigidis 7-10 $\mathrm{cm}$. longis, canalibus resiniferis numerosis in textura virente externis, strobilis solitariis v. 2-3 verticillatis, junioribus subterminalibus mucronatis, adultis 4-6 $\mathrm{cm}$. longis ovato-conicis obtusis subconformatis pedunculatis patulis $\mathrm{v}$. reflexis persistentibus in aetate matura dehiscentibus, squamarum apophysi subelevato-pyramidata nitido-fusca, umbone prominente saepe mucronato.

Western Szech'uan: Wa-ssu country, alt. 1600-2300 m., May and July 1908 (No. I475); Wa-shan, alt. 2000 m., September 1908 (No. 1477); Mao-chou, alt. 1900 m., May 1908, type specimen (No. I493); Niu-tow-shan, west of Kuan Hsien, alt. 2300 m., June 1908 (No. 2500); Min Valley, 1910 (No. 4056).

In many particulars this Pine resembles the previous species and ultimately may be united with it; the principal difference lies in its subsymmetrical cone and its possibly invariable number of fascicle leaves. The species is established on the representation of $\mathrm{Mr}$. Wilson, who considers it entirely distinct from all the other Pines that he has seen in China. 


\title{
SAXIFRAGACEAE.
}

\author{
PHILADELPHUS L.
}

Determined by E. KоенNe.

Philadelphus subcanus Koehne in Mitt. Deutsch. Dendr. Ges. XIII. 83 (1904). — Schneider, Ill. Handb. Laubholzk. I. 369 (1905).

Western Szech'uan: Mupin, thickets, alt. 1500-2100 m., June 1908 (No. 3039); Wa-shan, thickets, alt. 2100-2400 m., June 1908 (No. 3040); southeast of Tachien-lu, thickets, alt. 1800-2300 m., June 1908 (No. 3042); Wa-ssu country, Wên-chuan Hsien, alt. 18002300 m., July 1908 (No. 3043).

I formerly found the style pilose, but now I find it glabrous in some flowers of Wilson's specimens.

Philadelphus subcanus, var. dubius Koehne, $n$. var.

Ramuli floriferi etiam infra racemum laxe pilosi (in typo ibidem glabri). Folia subtus etiam inter nervos dense pilosa, interdum etiam supra pilosa. Stylus saepe glaber.

Western Szech'uan: Pan-lan-shan, west of Kuan Hsien, alt. 1500-2300 m., June 1908 (No. 3044); Min valley, Kuan Hsien, alt. 900 m., June 2, 1908 (No. 3045).

By its leaves being pilose also on the upper surface this variety seems to approach P. Magdalenae Koehne, but in that species the ovaries and sepals are brownish violet outside which I have never observed in $P$. subcanus. No. 3045 and part of No. 3044 have the leaves on the upper surface and the style glabrous, while one part of No. 3044 has the leaves above and the style at the base pilose.

Philadelphus Wilsonii Koehne, n. sp.

Frutex $2 \mathrm{~m}$. v. 3.3-6 m. altus; cortex ramorum biennium persistens albido-griseus; ramuli juveniles sub anthesi [innovationes desiderantur] fusci glabri; gemmae absconditae. Petioli 8-12 $\mathrm{mm}$. longi crassiusculi, subtus laxe subaccumbenti-pilosi; lamina e basi rotundata $\mathrm{v}$. contracta ovato-oblonga v. ovato-elliptica, 10-16 cm. longa, 4.8-7.6 cm. lata, infimis supremisque binis exceptis multoties minoribus, leviter longiuscule $\mathrm{v}$. breviter acuminata, denticulata denticulis sat remotis ad mucronem reductis, supra pilis brevissimis remotissimis 
conspersa, subtus in costa nervis venisque validioribus sat dense, inter venas laxius molliuscule pilosa, fructificationis tempore subglabra, membranacea, nervorum paribus 2 rarius 3 . Racemi $13-14 \mathrm{~cm}$. longi, laxi, 9-11-flori, axi glabro v. pilis remotissimis paucissimis consperso; florum paria 1-2 infima foliis magnis, sequens foliis parvis, cetera bracteis hypsophylloideis fugacibus suffulta; pedicelli inferiores $10-15 \mathrm{~mm}$. longi, ceteri subdecrescentes, pilis erecto-patentibus subcinerei; ovarium $5 \mathrm{~mm}$. longum, ut sepala ad $7 \mathrm{~mm}$. longa fuscescens pilis mollibus teneris accumbentibus breviusculis subcinerea; sepala intus basi excepta albo-tomentosa; corolla alba, circiter $3.3 \mathrm{~cm}$. lata, petala ovali-orbicularia; stamina circ. 28 , dimidiam petalorum partem paullo superantia ad $9 \mathrm{~mm}$. longa; stylus 9-11 mm. longus stamina aequans v. paullo superans, basi, ut discus sat planus, molliter pilosus (in fructibus vero pilos non vidi), usque ad stigmata indivisus; stigmata secus marginem exteriorem antheras longitudine aequantia. Capsula 9-12 $\mathrm{mm}$. longa, apice convexo glabro sepalorum insertionem triente fere superans.

Western Szech'uan: Wa-ssu country, Wên-chuan Hsien, alt. 1500-2700 m., July 1908 (No. 304r). Western Hupeh: Fang Hsien, alt. 2100 m., November 1907 (No. 58I).

Allied to $P$. subcanus from which it chiefly differs in the unusually large leaves of the flowering branchlets. No. 581, though differing from the type in the subglabrous leaves and the glabrous apex of the fruit, probably belongs to this species.

Philadelphus incanus Koehne in Gartenfl. XLV. 562 (excludenda planta Henry No. 8823 quae ad $P$. subcanum pertinet) (1896). Schneider, Ill. Handb. Laubholzk. I. 370 (1905).

Western Hupeh: Hsing-shan Hsien, thickets, alt. 1200-1800 m., June and October 1907 (No. 574), April 1907 (No. 3048), May 1907 (No. 3054), July 1907 (No. 3055); north of Ichang, thickets, alt. 1200$2100 \mathrm{~m}$., July and November 1907 (No. 583); north and south of Ichang, thickets, alt. 1200-1800 m., June 1907 (No. 3049); Fang Hsien, thickets, alt. 1500-2100 m., July 1907 (No. 3047); Changyang Hsien, alt. 1200-1800 m., June 1907 (No. 3050); Chang-lo Hsien, alt. 600-1200 m., June 1907 (No. 305I), alt. 1200-1800 m., June 1907 (No. 3052); Patung Hsien, thickets, alt. 1200 m., July 1907 (No. 3053).

Besides in other characters it differs from $P$. subcanus in the longer and more rigid hairs which cover the ovary and the sepals.

Philadelphus brachybotrys Koehne, n. sp.

Philadelphus pekinensis, var. brachybotrys Koehne in Mitt. Deutsch. Dendr. Ges. XIII. 84 (1904). - Schneider, Ill. Handb. Laubholzk. I. 373 (1904). 
This is not a variety of $P$. pekinensis Ruprecht (sect. Coronarii), but belongs to the section Satsumani, on account of the two years old branches having a close gray or brownish gray bark often divided by numerous horizontal cracks.

Philadelphus brachybotrys, var. purpurascens Koehne, n. var.

Frutex 1.4-6 m. altus. Petioli in ramulis florentibus 1-2 mm. longi, laxe pilosi v. glabri, in innovationibus ad $4 \mathrm{~mm}$. longi, laxe pilosi; lamina in innovationum foliis $3.5-5 \mathrm{~cm}$. longa, $1.3-2.2 \mathrm{~cm}$. lata, utrinsecus dentes $3-8$ ad $0.6 \mathrm{~mm}$. longos gerens, ciliata, in ramulorum florentium foliis $0.8-3.2 \mathrm{~cm}$. longa, $0.5-1.7 \mathrm{~cm}$. lata, denticulis minutis paucis, supra ut in typo laxe pilosa, subtus vero nonnisi in nervis primariis pilis longiusculis rigidis accumbentibus obsita v. interdum glabra; nervorum paria plerumque 2 . Ramuli florentes $3-8.5 \mathrm{~cm}$. longi adjecto racemo $2-4.5 \mathrm{~cm}$. longo 3-7-floro, axi glabro; pedicelli infimi 6-8 $\mathrm{mm}$. longi, glabri, ut axis ovaria sepalaque saepe purpurascentes; corolla alba $1.8-2.7 \mathrm{~cm}$. diam., petala ovali-rotundata, $10-14 \mathrm{~mm}$. longa, 8-10 mm. lata; stamina 32,33 . Stylus vix ultra medium indivisus. Fructus $8 \mathrm{~mm}$. longus, $6 \mathrm{~mm}$. diam., tertia parte convexa sepalorum insertionem superans.

Western Szech'uan: Ta-p'ao-shan, northeast of Tachien-lu, thickets, alt. 2750-3200 m., July 3, 1908 (No. 3046); west of Tachienlu, thickets, alt. 3000 m., June and October 1908 (No. I346).

\section{DEUTZIA Thunb.}

\section{Determined by ALFRED ReHDer.}

Deutzia scabra Thunberg, $F l$. Jap. 185, t. 24 (1784). - Lindley in Bot. Reg. XX. t. 1713 (1835). - Hooker in Bot. Mag. LXVII. t. 3838 (1841). - Hemsley in Jour. Linn. Soc. XXXIII. 276 (1887). Schneider, Ill. Handb. Laubholzk., I. 379, fig. 242 l-q, 243 a-f (1905).

D. crenata Siebold \& Zuccarini, Fl. Jap., I. 19, t. 6 (1835). - Maximowicz in Mém. Acad. Sci. St. Pétersb. sér. 7, X. No. XVI. 22, t. 2, fig. 27-31 (1867). Deutzia Fortunei, Carrière in Rev. Hort., 1866, p. 338.

Kiangsi: Kuling, abundant, alt. 1200 m., July 29, 1907 (No. I569). Kiangsu: Stronach (ex Hemsley).

The Kiangsi specimen has remarkably large capsules, about $7 \mathrm{~mm}$. in diameter, and large leaves ovate-oblong to lanceolate and broadly cuneate at the base. Hemsley cites also specimens from Hupeh and Formosa; the first quotation probably refers to the following species, the second to D. taiwanensis. 


\section{Deutzia Schneideriana Rehder, n. sp.}

Deutzia staminea Hemsley in Jour. Linn. Soc. XXIII. 277 (not R. Brown) (1888).

Deutzia crenata Hemsley, l.c. (in part as to the Hupeh specimens) (not Siebold \& Zuccarini).

Frutex 1-2 m. altus ramulis fusco-purpureis, initio sparse stellatopilosis, mox glabrescentibus, vetustioribus griseo-brunneis cortice detersili. Gemmae pluri-perulatae, stellato-pilosae. Folia subchartacea, elliptico-ovata, interdum ovata v. elliptico-oblonga, breviter acuminata, basi late cuneata $\mathrm{v}$. interdum rotundata, argute serrulata, $3.5-7 \mathrm{~cm}$. longa et $1.5-3 \mathrm{~cm}$. lata, supra pilis 5-6-radiatis laxe conspersa, subtus canescentia v. albida, dense pilis 12-14-radiatis obtecta, ad venas pilis longis simplicibus instructa, utrinsecus 4-6-costata; petioli parce stellato-pilosi, 3-4 mm. longi. Inflorescentia late paniculata, 3-6 cm. longa; calyx hemisphericus, dense stellato-pilosus dentibus triangularibus tubum subaequantibus; petala oblonga, circa $10 \mathrm{~mm}$. longa, extus stellato-pilosa; stamina longiora petalis quarta parte breviora v. interdum fere aequantia, filamentis dilatatis apice manifeste dentatis dentibus antheram vix attingentibus; styli plerumque 3, graciles, stamina subaequantes. Capsula hemispherica, apice leviter contracta, 5-7 $\mathrm{mm}$. diam., calyce deciduo.

Western Hupeh: Chang-lo Hsien, thickets, alt. 900-1200 m., June 1907 (No. 2889, type); without locality, June 1901 (Veitch Exped. No. 2152, 2152 ${ }^{\text {a }}$; Ichang, A. Henry (No. 3571); without locality, A. Henry (No. 1968).

Most nearly related to $D$. scabra Thunberg, which is easily distinguished by the leaves being only sparingly stellate-pubescent and therefore green on the underside, without simple hairs on the veins, by their crenulate-serrate margin with appressed serratures and by the narrow, nearly cylindric panicles, while the related D. hypoleuca Maximowicz differs in its five styles and narrow panicles. I take pleasure in associating with this species the name of Mr. C. K. Schneider whose "Beitrag zur Kenntnis der Gattung Deutzia" (in Mitt. Deutsch. Dendr.Ges. XIII. 172-188 (1904) is a valuable contribution to the knowledge of this genus.

Deutzia Schneideriana, var. laxiflora Rehder, n. var.

A typo differt praecipue foliis subtus viridibus, sparsius stellatopilosis, paniculis laxioribus latioribusque. Frutex 2-2.5 m. altus. Folia oblongo-lanceolata, acuminata, basi rotundata v. late cuneata, remote et irregulariter denticulata, $5-7 \mathrm{~cm}$. longa et $1.5-2.3 \mathrm{~cm}$. lata, supra pilis 4-5-radiatis sparsius, subtus pilis 10-12-radiatis densius conspersa. Panicula 6-9 cm. longa et 5-8 cm. lata, ramulis infimis floribus inclusis $4-5 \mathrm{~cm}$. longis; petala $12-14 \mathrm{~mm}$. longa, acutiuscula. Capsula $5 \mathrm{~mm}$. diam. Ceterum ut in typo. 
Western Hupeh: north and south of Ichang, alt. 900-1400 m., June and December 1907 (No. 767).

Differs from the type chiefly in the leaves being on their under side only sparingly stellate-pubescent and therefore green, and in the looser and broader panicles.

Deutzia pilosa Rehder, n. sp.

Frutex metralis ramulis fuscis, junioribus pilis longis patentibus ferrugineis instructis, secundo anno tarde glabrescentibus. Folia brevissime petiolata, membranacea, ovata v. ovali-ovata v. oblongoovata, longe acuminata acumine saepe falcato, basi rotundata $\mathrm{v}$. subcordata, argute mucronulato-serrulata, $3-6.5 \mathrm{~cm}$. longa et 1.5-3 $\mathrm{cm}$. lata, concoloria, supra pilis stellatis 3-4-radiatis et insuper radio centrali longiore instructis, subtus pilis 4-6-radiatis radio centrali instructis conspersa et ad venas pilis simplicibus patentibus praedita; petioli dense pilosi, 1-2 mm. longi. Cyma 3-9-flora, rarius uniflora, bracteis lineari-lanceolatis v. ebracteata, pilis ferrugineis patentibus instructa, pedunculo gracili, $1.5-3.5 \mathrm{~cm}$. longo; flores graciliter pedicellati; dentes calycis late ovati subito breviter acuminata, tubo dense pube homomorpha v. interdum heteromorpha obtecto dimidio breviores; petala oblongo-ovata, circa $8 \mathrm{~mm}$. longa, extus dense stellato-pilosa; stamina petalis fere dimidio breviora, filamentis exteriorum manifeste dentatis dentibus lanceolatis falcatis antheram fere sessilem multo superantibus, interiorum lanceolatis antheram faciei interiori circa medium affixam gerentibus; styli $3-4$, staminibus multo breviora, $1.5 \mathrm{~mm}$. longa. Capsula subglobosa, circa $5 \mathrm{~mm}$. diam., calycis dentibus persistentibus incurvis.

Western Szech'uan: west of Kuan Hsien, thickets, alt. 12001500 m., June 19, 1903 (No. 2896, type); Mt. Omei, May 1904 (Veitch Exped. No. 4884).

In its spreading pilose ferrugineous pubescence and its long peduncled fewflowered inflorescence this is very unlike any other species. No. 4884 differs from the type somewhat in the heteromorphous pubescence of the calyx and in the less marked development of the central ray of the hairs on the upper side of the leaves.

Deutzia setchuenensis Franch., var. longidentata Rehder, n. var.

Folia ovata v. oblongo-ovata, rarius oblongo-lanceolata, 4-8 cm. longa, concoloria, supra pilis plerumque 4-radiatis, subtus plerumque 6-radiatis, 5-7-radiatis rarius 8-radiatis interspersis, radio centrali destitutis conspersa. Cyma pauciflora, longe pedunculata, pedicellis gracilibus; filamenta staminum exteriorum dentibus lanceolatis antheram multo superantibus, interiorum lanceolata antheram faciei interiori infra medium affixam gerentia; ceterum ut in typo. 
Western Szech'uan: Chin-ting-shan, thickets, alt. 1200-1500 m., May 25, 1908 (No. 2895).

Differs from the type chiefly in its elongated filaments much exceeding the anthers as well in the interior as in the exterior stamens, in the smaller cymes and in the green only sparingly stellate-pubescent under side of the leaves. This may be a distinct species, if the characters should prove to be constant, but as the material at hand is meagre and does not seem of quite normal development, it may be referred provisionally to $D$. setchuenensis as a variety.

Deutzia setchuenensis var. corymbiflora Rehder, n. var.

Deutzia corymbiflora Lemoine in Gard. Chron., ser. 3, XXIII. 121; XXIV. 265, fig. 76 (1898); in Rev. Hort., 1898, 401, fig. 138; in Rev. Hort. Belg. XXV. 67 (1898). - Schneider in Mitt. Deutsch. Dendr. Ges. XIII. 180 (1904).

Deutzia setchuenensis Hutchinson in Bot. Mag. CXXXV. t. 8255 (1909).

Deutzia corymbiflora erecta Lemoine in Jour. Soc. Hort. France, sér. 4, III. 308 (1902).

Western Hupeh: Fang Hsien, thickets, alt. 900-1500 m., June 1910 (No. 4486). - Originally introduced into cultivation from eastern Szech'uan.

Differs from the type chiefly in the denser more or less heteromorphous pubescence of the leaves and the many-flowered inflorescence with the pedicels as long or shorter than the calyx. Deutzia corymbiflora erecta Lemoine differs slightly in its more ascending branchlets, smaller inflorescence and narrower leaves with sometimes nearly homomorphous pubescence. The Deutzia figured by Burvenich (in Rev. Hort. Belg. XXVII. 157, t.) as D. corymbiflora does not belong here, but is apparently $D$. purpurascens (Franchet) Rehder or one of its hybrids.

Deutzia coriacea Rehder, n. sp.

Frutex metralis ramulis annotinis cinereo-fuscis peridermate tarde decorticante, hornotinis fusco-flavidis glabris. Gemmae parvae perulis 4 exterioribus stellato-pilosis. Folia coriacea partim per secundum annum persistentia, ovata, acuminata, basi rotundata v. late cuneata, spinoso-dentata, $3-5.5 \mathrm{~cm}$. longa et $2-3 \mathrm{~cm}$. lata, supra glaberrima, nitida, flavido-viridia, subtus pallide viridia, pilis minutis, 5-7-radiatis conspersa, utrinsecus 4-6-costata; petioli purpurascentes, glabri, 5-7 mm. longi. Cymae e gemmis lateralibus et terminalibus aphyllis orientes, pedunculo $2-5 \mathrm{~mm}$. longo, rarius longiori insidentes, 5-9florae; flores desiderantur. Capsulae breviter pedicellatae, ovoideohemisphericae leviter costatae, circa $4 \mathrm{~mm}$. longae, pube homomorpha stellato vestitae; calycis dentes capsula dimidio breviores, late triangulares, erecti v. leviter incurvi; styli 3 , circa $2 \mathrm{~mm}$. longi, persistentes.

Eastern Szech'uan: Taning Hsien, limestone cliffs, alt. $600 \mathrm{~m}$., June 26, 1910 (No. 448I).

Deutzia coriacea is a very striking species with its coriaceous lustrous almost spiny foliage; it is most nearly related to $D$. Fargesii Franchet, which is easily dis- 
tinguished by its long-peduncled lax inflorescence and by the narrower, thinner, denticulate, scarcely lustrous leaves.

Deutzia Fargesii Franchet in Jour. de Bot. X. 281 (1890).

Western Hupeh: Fang Hsien, thickets, alt. 900-1200 m., June 1910 (No. 4488). Eastern Szech'uan: Ky-min-se, near Chang-k'on, R. P. Farges (No. 1043).

Franchet describes the leaves "utraque facie glabra" but they are on the under side rather densely covered with closely appressed, minute, 6-7-radiate hairs, hardly visible to the naked eye.

Deutzia glomeruliflora Franchet in Nouv. Arch. Mus. Paris, sér. 2, VIII. 236 (Pl. David. II. 54) (1885).

Western Szech'uan: Mupin, April 1869, A. David (ex Franchet); Mupin, thickets, alt. 1800-2100 m., June and October 1908 (No. Ir88); Tachien-lu, thickets, alt. 1800-2500 m., June 1908 (No. 289r), alt. 1300-2700 m., June 1908 (No. 290I); valley of Hsao-chin Ho, near Monkong Ting, alt. 2100-2400 m., June 1908 (No. 2899); Chetoshan, southwest of Tachien-lu, alt. 3500 m., October 1910 (No. 4383); no locality, May 1904 (Veitch Exped. No. 3568). Yunnan: woods near Fang-yang-chang, alt. 3000 m., June 7, 1888, J. M. Delavay.

Wilson's specimens show a wide range of variation. His No. 2891, with its small and dense inflorescences on short branchlets bearing only a few small leaves and sometimes nearly leafless, seems nearest to the type. All his specimens, however, have the flowers larger than those described by Franchet, particularly No. 2901, which has the petals $14 \mathrm{~mm}$. long and $10 \mathrm{~mm}$. broad. Sometimes, as in No. 2899, the flowers are borne on elongated branchlets with three pairs of well developed leaves. This tends to show that the type specimen does not present the normal development of the species, but a somewhat abnormal precocious state, as may be inferred from the fact that the type specimen was collected in April, while Wilson's flowering specimens were all gathered in June. No. 1188 has the pubescence of the calyx heteromorphous, as described by Franchet, while in the other specimens the pubescence is homomorphous except in Delavay's specimen from Yunnan, which differs besides in its broader leaves.

Deutzia glomeruliflora $\times$ longifolia Rehder, $n$. hybr.

Frutex $2 \mathrm{~m}$. altus ramulis rubro-fuscis, junioribus stellato-pilosis, annotinis peridermate solubili. Folia ovato-oblonga v. ovato-lanceolata, acuminata, basi rotundata v. late cuneata, argute serrata, 2.5-5 $\mathrm{cm}$. longa et 1-1.5 $\mathrm{cm}$. lata, supra laete viridia pilis 4-5-radiatis conspersa, subtus pallidiora v. canescentia pilis 5-8-radiatis partim radio centrali instructis et ad venas etiam simplicibus et fasciculatis interspersis obtecta; petioli stellato-pilosi, circa $2 \mathrm{~m}$. longi. Cyma convexa, in apice ramulorum brevium; pedicelli plerumque tubum calycis aequantibus; calycis dentes lanceolati tubum pube hetero- 
morpha praeditum superantes; petala 10-14 mm. longa, extus plerumque purpurascentia; stamina dimidiis petalis vix longiora, exteriora filamentorum dentibus antheram fere aequantibus v. superantibus, interiora filamentis lanceolatis antheram longe superantibus; styli stamina subaequantes.

Western Szech'uan: Tachien-lu, alt. 1200-1800 m., May 1908 (No. 2893); Wa-ssu country, Wên-chuan Hsien, alt. 1200-1800 m., July 1908 (No. 2890); Nin-tou-shan, west of Kuan Hsien, alt. 1200-1800 m., June 20, 1908 (No. 2900).

Wilson's No. 2993, from which the description given above is drawn, is in its characters clearly intermediate between $D$. glomeruliflora Franchet and $D$. longifolia Franchet, and I have no doubt that it is a hybrid between these two species, both of which have been collected in the neighborhood of Tachien-lu. The other two numbers seem closer to $D$. longifolia and may possibly represent a white-flowered variety of that species, though they differ in the pubescence. The intermediate character of the hybrid is most clearly shown in the hairs of the under side of the leaves, which have 4-6 rays in D. glomeruliflora and 12-14 in D. longifolia, while in No. 2993 they have 5-8 rays and in the other two numbers 8-10 rays. The flowers are white in the first species, purplish outside in the second species, and slightly purplish in No. 2993, while in the two other numbers they are white as in D. glomeruliflora. In habit the hybrid resembles most the last named species.

The species of Deutzia are known to hybridize easily in cultivation, and they seem to do the same in a wild state if they have the opportunity, for besides the hybrid described here, another hybrid, between $D$. discolor and $D$. mollis, described below, has been collected in a wild state.

Deutzia subsessilis Rehder, n. sp.

Frutex $1.5 \mathrm{~m}$. altus ramulis gracilibus, junioribus parcissime stellatopilosis, annotinis cortice detersili fusco praeditis. Gemmae perulis ovatis acutis stellato-pilosis. Folia membranacea, oblongo-ovata, acuminata acumine obtuso mucronulato, basi rotundata, argute serrulata, 3-6 $\mathrm{cm}$. longa et $1.5-2.5 \mathrm{~cm}$. lata, supra obscure viridia $\mathrm{v}$. flavo-viridia, pilis sparsis plerumque 4-radiatis conspersa, subtus pallidiora, pilis 4-5-radiatis laxe conspersa et sub lente minute punctulata, utrinsecus 4-5-costata; petioli in ramulis floriferis subnullis, in innovationibus circa $1 \mathrm{~mm}$. longi, parce stellato-pilosi. Cyma pluriflora, convexa, plerumque sessilis, parce stellato-pilosa; pedicelli graciles; calyx stellato-tomentosus, dentibus triangularibus tubo aequilongis $\mathrm{v}$. paullo longioribus trinerviis; petala oblonga, $10 \mathrm{~mm}$. longa et 6-7 $\mathrm{mm}$. lata, alba, extus stellato-pilosa; stamina petala dimidia aequantia, filamenta exteriorum apice manifeste bidentata dentibus triangularibus antheram breviter stipitatam subaequantibus, interiorum anguste oblonga, antheram faciei interiori circa medium affixam gerentia; styli 3, stamina subaequantes. Capsulae maturae desunt. 


\section{Western Szech'uan: Mupin, alt. 1800 m., June 1908 (No. II $\left.88^{\mathrm{a}}\right)$.}

From all the allied species this is easily distinguished by the nearly sessile leaves of the flowering branches; the other species with nearly sessile leaves, $D$. pilosa Rehder, D. Faberi Rehder, and D. Sieboldiana Maximowicz, are too different to be confounded with $D$. subsessilis.

Deutzia discolor Hemsley in Jour. Linn. Soc. XXIII. 275 (1887).

Hupeh: Patung distr., A. Henry (Nos. 5426, 5718); Hsing-shan Hsien, thickets, alt. 1200-1500 m., June and November 1807 (No. 570, 2886, 2887, 2888); without locality (Veitch Exped. Nos. 190, 710, $\left.1916^{\text {b }}, 2335,2335^{\text {a }}\right)$. Southern Shensi: Mt. Tun-u-sse, June 16-18, 1894, G. Giraldi (No. 771).

Deutzia discolor shows considerable variation in the size of the flowers, density and size of the inflorescence and in the shape of the filaments. A very large-flowered form has been distinguished as $D$. discolor var. major Veitch, Cat. 1905, fig. ex Kew Bull. Misc. Inform., 1906, appx. I. 67; Novelties for 1907, 14. The No. 2887 has the flowers white and pink, but does not differ otherwise from D. discolor.

\section{Deutzia densiflora, Rehder, n. sp.}

Frutex bimetralis ramulis robustis, junioribus floriferis glabris v. fere glabris, foliiferis parce stellato-pilosis, annotinis rubro-fuscis cortice detersili. Gemmae perulis late ovatis abrupte acuminulatis stellato-pilosis. Folia membranacea, ovato-oblonga v. oblonga, acuta v. breviter acuminata, basi rotundata $\mathrm{v}$. interdum late cuneata, argute serrulata, 4-7 cm. longa et $1.5-2.8 \mathrm{~cm}$. lata, supra obscure viridia, pilis 4-5-radiatis sparse conspersa, subtus canescentia, dense pilis 9-12-radiatis obtecta, utrinsecus 5-6-costata; petioli stellato-pilosi, 2-4 mm. longi. Cyma densa, late pyramidalis, ad $7 \mathrm{~cm}$. longa et 6 cm. diam., fere glabra, in apice ramulorum perbrevium plerumque paribus foliorum duobus in axillis cymas partiales gerentibus instructorum; pedicelli stellato-pilosi, tubum calycis stellato-pilosi subaequantes, dentes calycis ovati, abrupte acuminulati, tubo paullo breviores; petala elliptico-oblonga, alba, extus sparse stellato-pilosa, 8-9 $\mathrm{mm}$. longa; stamina petalis tertia parte breviora, filamenta exteriorum apice manifeste dentata, dentibus triangularibus stipitem antherae plerumque subaequantibus $\mathrm{v}$. paullo superantibus, interiorum anguste oblonga, apice obtusa v. obsolete denticulata, antheram circa medium affixam gerentia; styli 3 , staminibus longioribus paullo breviores. Capsulae maturae desiderantur.

Western Hupeh: Hsing-shan Hsien, side of streams, alt. 12001500 m., May 19, 1907 (No. 2885). 
Allied to Deutzia discolor Hemsley, which is easily distinguished by its looser cymes, lanceolate calyx-teeth and by the interior filaments not exceeding the anthers and usually bidentate.

Deutzia longifolia Franchet in Nouv. Arch. Mus. Paris, sér. 2, VIII. 235 (Pl. David. II. 53) (1885).

Szech'uan: Mupin, David (ex Franchet); Mupin, thickets, alt. 1500-2300 m., June and October 1908 (No. II86); southeast of Tachien-lu, thickets, alt. 1800-2700 m., June and October 1908 (No. I321, I322, 2892); Wa-shan, thickets, common, alt. 1500-1800 m., June and November 1908 (No. 1340); Pan-lan-shan, west of Kuan Hsien, thickets, alt. 2400-2700 m., October 1910 (Nos. 4298, 4326); Sungpan, thickets, alt. 2700 m., October 1910 (No. 4300); without locality, July 1903 (Veitch Exped. No. 3567, 3567ª); Tachien-lu, A. E. Pratt (No. 677).

Though Wilson's specimens differ from the description of D. longifolia Franchet, of which I have not seen the type, in the broader leaves and larger flowers, I have no doubt that they must be referred to this species. The leaves of Wilson's specimens are sometimes ovate-oblong and $3 \mathrm{~cm}$. broad and the petals attain $14 \mathrm{~mm}$. in length. From the allied species $D$. longifolia is readily distinguished by the narrower, rather thickish leaves, rugose above and with strongly elevated veins on the whitish under side, by the heteromorphous pubescence of the under side, the purplish flowers in many-flowered paniculiform cymes usually loose and borne on elongated branchlets, but sometimes rather dense and on short branchlets, by the usually four styles and larger capsules measuring about $6 \mathrm{~mm}$. in diameter.

Deutzia mollis Duthie in Gard. Chron. ser. 3, XL. 238 (1906).

Hupeh: without locality (Veitch Exped. Nos. 1959, 2282, type); Hsing-shan Hsien, thickets, alt. 1500-1800 m., June 1907 (No. 2894).

A natural hybrid of this species with $D$. discolor is described below.

Deutzia rubens Rehder, n. sp.

Frutex metralis ramulis gracilibus rubro-fuscis, junioribus sparsissime stellato-pilosis, mox glabrescentibus, annotinis cortice detersili. Gemmae perulis numerosis lanceolatis, acuminatis, exterioribus glabris, obscure castaneis. Folia membranacea, oblonga v. ovatooblonga, acuminata, basi plerumque attenuata, rarius rotundata, argute minuteque serrulata serraturis plerumque purpureis, $4-7 \mathrm{~cm}$. longa et 1.5-3 cm. lata, subconcoloria, utrinque sparse stellato-pilosa, supra plerumque pilis 4-radiatis, subtus 5-6-radiatis insuperque minute punctulata, utrinsecus 5-6-costata; petioli sparse stellatopilosi, 2-4 mm. longi. Cyma pluriflora v. multiflora, convexa, parce stellato-pilosa, plerumque breviter pedunculata; pedicelli graciles, ad $2.5 \mathrm{~cm}$. longi; calycis stellato-pilosi dentes ovati, subito acuminulati, 
tubum subaequilongi v. paullo tantum breviores; petala obovata, $10 \mathrm{~mm}$. v. interdum $5 \mathrm{~mm}$. longa, $7-8 \mathrm{~mm}$. lata, alba, extus rubescentia et sparse stellato-pilosa; stamina petalis tertia parte breviora, filamenta exteriorum apice obtusa v. obsolete 2-3-dentata, antheram breviter stipitatam paullo infra apicem affixam gerentia, interiorum antheram circa medium affixam gerentia; styli tres, stamina subaequantes. Capsula hemispherica, $4-5 \mathrm{~mm}$. diam. lobis diu persistentibus reflexis, demum deciduis.

Western Szech'uan: Pan-lan-shan, west of Kuan Hsien, cliffs, alt. 2100-2700 m., June 1908 (No. 2902, type); Nin-tou-shan, west of Kuan Hsien, thickets, alt. 1500-2100 m. (No. 2898); Chin Ting-shan, thickets, alt. 1800 m., May 23, 1908 (No. 2897); Wa-shan, alt. 3000 m., July 1903 (Veitch Exped. No. 3566). Hupeh; without locality (Veitch Exped. No. 1919).

Related to $D$. corymbosa R. Brown and $D$. parviflora Bunge, from both of which it is easily distinguished by the hairs on the under side of the leaves having only 5-6 rays, by the filaments extending undivided above the insertion of the anthers, and by the color of the flowers. The flowers vary greatly in size; in the type the petals are $10 \mathrm{~mm}$. long, while in No. 2897 they are scarcely $5 \mathrm{~mm}$. long and slightly longer in No. 3566; in No. 1919 they are $7 \mathrm{~mm}$. long. No. 3586 differs besides in its smaller leaves nearly glabrous beneath.

\section{SYNOPSIS OF THE CHINESE DEUTZIAS.}

While determining the Deutzias of the Wilson collection I have found a large amount of undetermined material which led me to a closer study of all the Chinese species. The results of this study are embodied in the following key and enumeration of the Chinese species.

\section{KEY TO THE SPECIES.}

Praefloratio induplicato-valvata . . . . . . . . Sect. I. EUDEUTZIA.

* Inflorescentia manifeste paniculata, sessilis; calycis dentes tubo breviores; filamenta dentata $\nabla$. edentata, antheram non superantia.

Folia pube dimorpha instructa, pilis subtus 10-15-radiatis.

Subsect. 1. SCABRAE.

Folia dense serrulata.

Panicula angusta; folia crenato-serrulata, subtus sparse stellato-pilosa, viridia, pilis simplicibus destituta . . . . . . . 1. D. scabra.

Panicula late pyramidalis; folia argute serrulata, subtus dense stellatopilosa, canescentia (in varietate viridia), pilis simplicibus ad venas instructa . . . . . . . . . 2. D. Schneideriana.

Folia remote denticulata.

Styli plerumque 3; petioli 1-3 mm. longi; folia utrinsecus 5-6-costata. 3. D. ningpoënsis.

Styli plerumque 5; petioli 5-10 mm. longi; folia utrinsecus 8-12-costata.

4. D. pulchra. 
Folia pube homomorpha instructa, pilis subtus 4-7-radiatis.

Filamenta edentata, petalis aequilonga; folia superiora ramulorum floriferorum subsessilia . . . . . . . . . 5. D. Faberi.

Filamenta dentata, petalis breviora; folia omnia petiolata.

6. D. taiwanensis.

** Inflorescentia corymbiformis $\nabla$. cymosa; filamenta staminum saltem interiorum antheram saepe superantia.

$\dagger$ Inflorescentia multiflora $\nabla$. pluriflora, rarius pauciflora.

$\ddagger$ Dentes calycis triangulares $v$. late ovati, dimidium tubum vix superantes; inflorescentia cymosa, laxa, plerumque pedunculata et saepe pauciflora; filamenta staminum interiorum antheram superantia, apice indivisa $\mathrm{v}$. irregulariter dentata.

Subsect. 2. CYMOSAE.

Pubes stellata pilis patentibus simplicibus ferrugineis interspersa; folia brevissime petiolata; cyma pauciflora, longe pedunculata.

7. D. pilosa.

Pubes omnino stellata, heteromorpha $\nabla$. homomorpha, pilis ferrugineis destituta.

Folia membranacea, denticulato-serrulata, utrinque stellato-pilosa pube saepe heteromorpha.

Flores albi; calycis dentes tubum dimidum vix aequantes; folia subtus cinereo-viridia . . . . . . . . 8. D. setchuenensis.

Flores rosei; calycis dentes tubum dimidium superantes; cyma multiflora ramis pedicellisque purpurascentibus; folia subtus albido-glaucescentia . . . . . . . . . 9. D. Silvestrii.

Folia coriacea v. chartacea, supra glabra v. fere glabra, persistentia, subtus pilis stellatis minutis homomorphis vestita.

Cymae densae, breviter pedunculatae; folia coriacea nitida, spinoso-dentata, ovata . . . . . . 10. D. coriacea.

Cymae laxae, longe pedunculatae; folia chartacea, denticulatoserrata, oblongo-lanceolata . . . . . . 11. D. Fargesii.

$\ddagger \ddagger$ Dentes calycis lanceolati v. oblongo-ovati tubum aequantes v. superantes, rarius paullo breviores; inflorescentia late pyramidalis, sessilis, plerumque satis densa, multiflora, rarius pauciflora (in No. 14).

Subsect. 3. STENOSEPALAE.

Pubes homomorpha $v$. fere homomorpha, pili paginae inferioris foliorum 4-6-radiati, interdum 7-radiatis interspersis.

Folia pube heteromorpha vestita, subtus molliter pubescentia; filamenta staminum interiorum lanceolata; flores albi.

12. D. glomeruliflora.

Folia pube homomorpha vestita subtus pilis stellatis adpressis conspersa; filamenta staminum interiorum anguste oblonga, apice truncata et irregulariter denticulata.

Folia subsessilia, basi rotundata, subtus pilis 4-5-radiatis praedita; flores albi .......... 13. D. subsessilis.

Folia petiolata, basi plerumque late cuneata, subtus pilis 5-7radiatis praedita; flores extus purpurascentes; cyma interdum pauciflora. . . . . . . . 14. D. purpurascens.

Pubes manifeste dimorpha, pili paginae inferioris cinerascentis $\nabla$. albidae foliorum 8-12-radiati.

Filamenta staminum interiorum apice bidentata dentibus antheram non superantibus $v$. infra apicem subito contracta. 
Filamenta fere edentata apicem versus attenuata $\nabla$. infra apicem abrupte contracta et tantum angulata angulis haud productis.

Calycis dentes tubo paullo breviores, ovato-oblongi, obtusiusculi; cyma laxa pedicellis gracilibus, $6-10 \mathrm{~mm}$. longis.

15. D. Wilsonii.

Calycis dentes tubum aequantes v. paullo superantes; cyma densa, pedicellis circa $5 \mathrm{~mm}$. longis.

Filamenta apice dentata; calycis dentes lanceolati.

Pedicelli circa $10 \mathrm{~mm}$. longi; cyma laxa; petala patentia; dentes filamentorum stipite antherae multo breviores.

17. D. Vilmorinae.

Pedicelli circa $5 \mathrm{~mm}$. longi; cyma satis densa.

Dentes filamentorum breves, antheram vix attingentes; petala margine reflexa. . . . . . . . 18. D. reflexa.

Dentes filamentorum elongati, antherae basin superantes, rarius paullo breviores; petala plana. 19. D. discolor.

Filamenta staminum interiorum lineari-oblonga, apice obtusa $\nabla$. obsolete dentata, antheram longe superantia, rarissime quam anthera paullo breviora.

Dentes calycis tubo paullo breviores, ovati, apice abrupte acuminulati; corymbus densus, pedicellis $2-3 \mathrm{~mm}$. longis calyce brevioribus. . . . . . . . . 20. D. densiflora.

Dentes calycis tubum aequantes $\nabla$. superantes, lanceolati.

Folia ovata $v$. oblonga, basi rotundata, integra $v$. minute denticulata; pedicelli calyce breviores; petala alba; styli staminibus fere duplo breviores; filamenta omnia antheras superantia . . . . . . . 21. D. albida.

Folia oblonga $\nabla$. lanceolata, basi attenuata, argute serrulata; pedicelli plerumque calyce longiores; petala rosea; styli staminibus aequilongi; antherae filamenta superantes.

22. D. longifolia.

†† Inflorescentia 1-3-flora, breviter pedunculatae (vide etiam No. 14).

$\ddagger$ Flores in apice ramulorum foliosorum; ovarium semisuperum; dentes calycis lanceolatae; filamenta dentibus recurvatis.

Subsect. 4. GRANDIFLORAE.

Dentes calycis in apice marginis calycini erecti brevissimi inserti.

Folia subtus stellato-tomentosa pilis multiradiatis, basi rotundatis v. subcordatis . . . . . . . . 23. D. grandiflora.

Folia subtus glabra pilis simplicibus ad venas exceptis v. interdum pilis rarissimis 5-radiatis instructa, basi late cuneata.

24. D. prunifolia.

Dentes calycis ad marginem annuli calycini horizontalis patellati exteriorem inserti; folia subtus glabra pilis stellatis versus nervorum basin exceptis . . . . . . . 25. D. hamata.

¥† Flores e gemmis aphyllis orientes, plerumque solitarii; folia oblonga v. lanceolata, subtus viridia, pilis 5-6-radiatis conspersa; ovarium totum inferum; dentes calycis triangulares, breves. Subsect. 5. COREANAE.

26. D. coreana.

Praefloratio imbricata ........ Sect. II. MESODEUTZIA.

* Folia subtus molliter pubescentia, pilis plerumque 4-radiatis radio centrali instructis et ad venas simplicibus obtecta; filamenta e basi dilatata sensim angustata ............ 27. D. mollis. 
** Folia subtus pilis multiradiatis adpressis conspersa $\nabla$. glabra.

$\dagger$ Filamenta edentata v. breviter dentata dentibus antheram non superantibus. Calyx stellato-pilosus; folia subtus sparse pilis 6-12-radiatis instructa.

Petala circa $6 \mathrm{~mm}$. longa; filamenta breviter dentata, rarius edentata; corymbus ramulis $1-2 \mathrm{~cm}$. longis.

Folia crenato-serrulata serraturis incurvis, basi rotundata, subtus pilis 8-12-radiatis conspersa; filamenta omnia dentata.

28. D. corymbosa.

Folia argute serrulata serraturis porrectis, basi plerumque late cuneata, subtus pilis 6-9-radiatis conspersa; filamenta saepe saltem exteriora edentata . . . . . . . . 29. D. parviflora. Petala circa $3.5 \mathrm{~cm}$. longa; filamenta subulata; corymbus multiflorus ramulis inferioribus ad $3 \mathrm{~cm}$. longis . . . . 30. D. micrantha.

Calyx et corymbus omnino glabra; folia subtus glabra v. sparsissime pilis 3-radiatis conspersa; filamenta subulata. 31 . D. glabrata.

†† Filamenta staminum exteriorum manifeste dentata dentibus antheram superantibus, interiorum lineari-oblonga antheram longe superantia.

Folia subtus stellato-pilosa, viridia, pilis 5-6-radiatis conspersa; petala extus rubescentes, calycis dentes plerumque purpurei, acuminulata.

32. D. rubens.

Folia subtus glaberrima, glauca; petala alba; calycis dentes pallidi, obtusi. 33. D. hypoglauca.

\section{ENUMERATION OF THE SPECIES.}

Sect. I. EUDEUTZIA Engler, Nat. Pflanzenfam. III. 29, p. 72 (in part) (1900). Schneider in Mitt. Deutsch. Dendr. Ges. XIII. 176 (1904).

Subsect. 1. SCABRAE Rehder, n. subsect.

Latisepalae Schneider in Mitt. Deutsch. Dendr. Ges. XIII. 176 (in part) (1904).

Inflorescence a sessile panicle with an elongated main axis and short, few- or several-flowered lateral branchlets; calyx-teeth ovate or triangular, much shorter than the tube; petals usually more or less upright; filaments not exceeding the anthers, without teeth or with short teeth not reaching the base of the anthers, two-thirds or nearly as long as the petals; styles slender, as long or not more than one-third shorter than the petals. Here belong, besides the species enumerated below, D. hypoleuca Maximowicz, D. Sieboldiana Maximowicz and D. gracilis Siebold \& Zuccarini.

1. Deutzia scabra Thunberg. See p. 6.

2. Deutzia Schneideriana Rehder. See p. 7.

3. Deutzia ningpoensis Rehder, n. sp.

Frutex ramulis gracilibus, junioribus rufobrunneis, sparse stellato-pilosis, vetustioribus pallide griseo-brunneis. Gemmae perulis acutis sparse stellato-pilosae. Folia subchartacea, ovato-oblonga, acuminata, basi rotundata v. late cuneata, remote et obsolete denticulata $\mathrm{v}$. fere integra, $3.5-7 \mathrm{~cm}$. longa et 1.5-3 cm. lata, supra obscure viridia, pilis 4-6-radiatis conspersa, subtus albido-tomentosa, dense pilis 12-14-radiatis obtecta, utrinsecus 5-6-costata; petioli stellato-pilosi, 1-2 mm. longi. Panicula 5-12 cm. longa et $2.5-6 \mathrm{~cm}$. lata, laxe stellato-pilosa, pedicellis 1-3 mm. longis; flores desunt. Capsula subglobosa, 3-4.5 mm. diam., dense stellato-pilosa, calycis dentibus dimidium tubum vix superantibus plerumque deciduis; stylis 3 , gracilibus, circa $8 \mathrm{~mm}$. longis.

Chekiang: Ningpo Mts., E. Faber ((Herb. Arnold Arboretum). 
Allied to $D$. hypoleuca Maximowicz which differs chiefly in its densely serrulate thinner leaves, the slenderer petioles, 2-5 mm. long and the 4-5 styles.

4. Deutzia pulchra Vidal, Revis. Pl. Vasc. Filip. 124 (1886).

For mosa: Bankinsing, A. Henry (Nos. 38, 477).

The occurrence of this Philippine species in Formosa is phytogeographically interesting. Henry's specimens agree exactly with Elmer's No. 8414 from the province of Benguet, except that in the latter the stellate hairs on the upper surface of the leaves have usually 4-6 rays interspersed with comparatively few hairs with 10-12 rays, while in the Formosa plant most of the hairs have 6-8 rays and many 10-14 rays. The inflorescence is not corymbiform as might be inferred from Vidal's description, but a panicle 6-11 $\mathrm{cm}$. long and 5-8 cm. broad.

5. Deutzia Faberi Rehder, n. sp.

Frutex ramulis gracilibus fuscis, junioribus stellato-pilosis, annotinis peridermate detersili. Gemmae multi-perulatae, stellato-tomentosae. Folia membranacea, oblonga v. anguste ovato-oblonga, acuminata, in ramulis floriferis subsessilia, basi rotundata, in sterilibus breviter petiolata, basi cuneata, dense minuteque serrulata serraturis adpressis, 4-8 cm. longa et $1.5-2.5 \mathrm{~cm}$. lata, laete viridia, concoloria, supra pilis 3-4-radiatis sat dense conspersis, subtus pilis plerumque 4-radiatis insuperque saepissime radio centrali elongato instructis pubem subvillosam formantibus praedita, utrinsecus 7-9-costata; petioli stellato-pilosi, 1-2 $\mathrm{mm}$. longi, in ramulis floriferis subnulli. Panicula sessilis, multiflora, laxa, 7-10 cm. longa, laxe stellato-pilosa; pedicelli graciles, pube heteromorpha vestita; calycis dentes minuti vix quartam partem tubi dense pube heteromopha vestiti turbinati longioris quam lati aequantes; petala oblonga, erecta, $10 \mathrm{~mm}$. longa et $4 \mathrm{~mm}$. lata, extus dense stellato-pilosa; stamina exteriora petalis aequilonga filamentis basi dilatatis apicem versus sensim angustatis $v$. paullo supra medium subito contractum angulatum, interiora filamentis paullo supra medium breviter dentatis; styli 3, graciles, stamina aequantes. Capsulae maturae desunt.

Chekiang: Tientai, Kiangsu Hills, E. Faber (No. 210, in Herb. Arnold Arboretum.).

Closely related to $D$. Sieboldiana Maximowicz, which is easily distinguished by its generally ovate leaves, more coarsely serrulate with spreading teeth, by the calyx-teeth being about half as long as the tube which is broader than long, and by its smaller flowers with more spreading petals.

6. Deutzia taiwanensis Schneider in Mitt. Deutsch. Dendr. Ges. XIII. 177 (1904).

D. crenata, var. ? \& taiwanensis Maximowicz in Mém. Acad. Sci. St. Pétersb. sér. 7, X. No. XVI. 23 (1867).

Formosa: near Tamsuy, 1864, R. Oldham (No. 107, in Herb. Kew.).

Subsect. 2. CYMOSAE Rehder, n. subsect.

Latisepalae Schneider in Mitt. Deutsch. Dendr. Ges. XIII. 176 (in part) (1904).

Inflorescence distinctly cymose, much broader than high, sometimes few-flowered; calyx-teeth much shorter than the tube, incurved at maturity; filaments, at least those of the inner stamens, exceeding the anthers, those of the outer row distinctly bidentate, these of the inner row with obtuse or irregularly dentate apex; styles scarcely half as long as the petals. Stellate hairs of the leaves with few rays, those of the under side usually with 5 or 6 , occasionally with 7 rays.

7. Deutzia pilosa Rehder. See p. 8.

8. Deutzia setchuenensis Franchet in Jour. de Bot. X. 282 (1896).

Deutzia scabra, var. ? cymis paucifloris Hemsley in Jour. Linn. Soc. XXIII. 277 (1887). 
Eastern Szech'uan: near Ch'eng-k'ou (ex Franchet). - Western Hupeh: Ichang, A. Henry (No. 3585); without locality, A. Henry (Nos. 3480, 4139); Fokien: April to June 1905, S. T. Dunn (Herb. Hongkong Bot. Gard. No. 2676).

I have not seen the type specimen itself, but a good photograph of it. As this and Franchet's description agrees fairly well with the specimens cited above, I trust that $I$ have made no mistake in referring them to $D$. setchuenensis.

Deutzia setchuenensis, var. longidentata Rehder. See p. 8.

Deutzia setchuenensis, var. corymbiflora Rehder. See p. 9.

9. Deutzia Silvestrii Pampanini in Nuov. Giorn. Bot. Ital. n. ser. XVII. 282 (1910).

Western Hupeh: near Siang-yang, C. Silvestri (Nos. 671, 868, 869, 870, 872).

I have seen no specimen of this species; according to the description by Pampanini it is nearest to $D$. setchuenensis var. corymbiflora, but differs chiefly in the longer calyx-lobes and narrower rose-colored petals.

10. Deutzia coriacea Rehder. See p. 9.

11. Deutzia Fargesii Franchet. See p. 10.

Subsect. 3. STENOSEPALAE Schneider in Mitt. Deutsch. Dendr. Ges. XIII. 184 (1904).

Calyx-teeth lanceolate or sometimes oblong-ovate, as long or longer, rarely slightly shorter, than the tube; the cymes usually rather dense and many-flowered, more or less panicle-like. Besides the following species $D$. staminea $\mathrm{R}$. Brown and probably D. macrantha Hooker f. and Thomson, which I have not seen, belong to this group.

12. Deutzia glomeruliflora Franchet. See p. 10.

13. Deutzia subsessilis Rehder. See p. 11.

14. Deutzia purpurascens Rehder, n. sp.

Deutzia discolor, var. purpurascens Franchet apud Henry in Le Jardin, 1894, 147, fig. 64. - Sargent in Gard. and For. VII. 284, 287, fig. 84 (1894).Gard. Chron. ser. 3, II. 45, fig. 25 (1899).- Hooker f. in Bot. Mag. CXXVI. t. 7708 (1900). - Lemoine in Jour. Soc. Hort. France, sér. 4, III. 301 (1902). - Schneider, Ill. Handb. Laubholzk. I. 381, fig. 244 e-f (1905).

Yunnan, J. M. Delavay (ex Franchet). - In cultivation (Arnold Arboretum, etc.).

Deutzia purpurascens differs in several important characters from $D$. discolor, and I consider it a well marked species much less closely related to $D$. discolor than any of the following species of this group. It is particularly well distinguished by the stellate hairs of the under side of the leaves which have only 5-7 rays, while in all the following species they have 10-14 rays, and besides from $D$. discolor by its smaller generally ovate leaves, greenish beneath, smaller inflorescence, purplish flowers, and shorter stamens with the filaments exceeding the anthers.

Deutzia purpurascens, var. pauciflora Rehder, n. var.

Frutex metralis ramulis gracilibus, junioribus stellato-pilosis, annotinis elevatoasperatis flavido-griseis. Gemmae parvae perulis late ovatis acutiusculis extus dense pubescentibus. Folia ovata v. oblongo-ovata, acuminata, basi rotundata $\mathrm{v}$. late cuneata, argute serrulata, $1.5-3.5 \mathrm{~cm}$. longa et 1-1.4 $\mathrm{cm}$. lata, laete viridia, concoloria, supra pilis 4-5-radiatis, subtus pilis 5-6-radiatis sparse conspersa; petioli sparse stellato-pilosi, 1-2 mm. longi. Cymae breves, 1-3-florae, stellatopilosae, ramulos laterales brevissimos terminantes; pedicelli $2-4 \mathrm{~mm}$. longi; calyx stellato-pilosus, dentibus ovato-oblongis obtusiusculis rubescentibus tubum aequantibus v. paullo longioribus; petala ovato-oblonga, $9 \mathrm{~mm}$. longa, margine erosa, alba; filamenta antheras superantia, exteriora dentibus obtusis, interiora apice obtuso; 
styli 3, stamina subaequantes. Capsula hemispherica, $4 \mathrm{~mm}$. diam., lobis reflexis deciduis.

Yunnan: Mengtze, “N. Mts.”, alt. 1800 m., A. Henry (No. 9475a).

Differs from the type chiefly in its few-flowered inflorescence, white petals, and in the apex of the filaments or of the teeth of the filaments being obtuse. Possibly a distinct species.

15. Deutzia Wilsonii Duthie in Bot. Mag. CXXXII. t. 8083 (1906).

Eastern Szech'uan: South Wushan, cliffs, May 1901, E. H. Wilson (Veitch Exped. No. $1916^{a}$ ). In cultivation; raised from seed collected by E. H. Wilson (Veitchian nurseries, Combe Wood).

This and the following three species are closely related to D. discolor Hemsley, and I am not yet quite convinced that they are really specifically distinct; the characters on which they are based seem to be rather slight and inconstant, but as the material I have seen of each of these species is rather scant, I do not feel justified to make a change, until more and completer material is available.

16. Deutzia globosa Duthie in Gard. Chron. ser. 3, XL. 238 (1906).

Raised from seed collected by E. H. Wilson in Hupeh and cultivated in the Veitchian nurseries, Combe Wood: Ex hort. Veitch. No. 118 $/ 2$, June 6, 1905 (Herb. Kew, type).

17. Deutzia Vilmorinae Lemoine, Cat. No. 158, p. vii, fig. (1904). - C. K. Schneider in Mitt. Deutsch. Dendr. Ges. XIII. 182 (1904); Ill. Handb. Laubholzk. I. 381 (1905).

Western Hupeh: without locality, June 1900, E. H. Wilson (Veitch Exped. No. 940); June 1901 (No. 1998). Raised from seed collected by Farges in Szech'uan and first distributed by Lemoine of Nancy.

18. Deutzia reflexa Duthie in Gard. Chron. ser. 3, XL. 238 (1906).

Raised from seed collected by E. H. Wilson in Hupeh and cultivated in the Veitchian nurseries, Combe Wood; Wilson, No. 1253, June 2, 1910 (W. J. Bean in Herb. Kew.).

19. Deutzia discolor Hemsley. See p. 12.

$19 \times 20$. Deutzia discolor $\times$ mollis Rehder, $\mathrm{n}$. hybr.

Frutex ramulis junioribus parce stellato-pilosis, annotinis peridermate castaneo in lamellas tenues soluto. Folia oblonga, acuminata, basi late cuneata v. rotundata, argute serrulata, $4.5-6 \mathrm{~cm}$. longa et $1.5-2.2 \mathrm{~cm}$. lata, supra pilis 4-5-radiatis conspersa, subtus molliter pubescentia, pilis 7-10-radiatis (plerumque 8-radiatis) radio centrali praesertim ad nervos instructis obtecta; petioli pilis heteromorphis praediti, $3 \mathrm{~mm}$. longi. Cyma convexa multiflora; calycis dentes ovato-oblongi, abrupte acuminati, tubum pube homomorpha obtectum aequantes; petala $5-6 \mathrm{~mm}$. longa, ovato-oblonga, aestivatione plerumque valvata, sed etiam partim imbricata; stamina petalis triente breviora, filamentis staminum exteriorum interdum e basi dilatata sensim attenuata sed saepius subito contractis et angulatis, interiorum plerumque infra apicem in dentes brevissimos productis, antheris sterilibus; styli tres, stamina paullo superantes.

Western Hupeh: June 1901, E. H. Wilson (Veitch Exped. No. 1917) (Herb. Arnold Arboretum.).

Wilson's No. 1917 is quoted by the author of $D$. mollis as belonging to that species and it looks indeed at the first glance only like a slight variation, but a closer examination reveals certain features which indicate at once its hybrid origin, particularly the irregular aestivation and the sterile anthers. All the other characters in which the plant in question differs from $D$. mollis point toward $D$. discolor as the other parent; the stellate hairs of the under side of the leaves have 12-14 
rays in $D$. discolor and generally 4 rays with a central ray in $D$. mollis, while in the hybrid they have generally 8 rays only part of them with a central ray; the calyx-lobes, which are lanceolate and longer than the tube in $D$. discolor and broadly ovate, abruptly acuminate and about half as long as the tube in $D$. mollis, are oblong-ovate, acuminulate and about as long as the tube in the hybrid; the filaments, which are gradually narrowed toward the apex in D. mollis and distinctly toothed in $D$. discolor, are in the hybrid mostly abruptly contracted or have only very short teeth; also the shape of the leaves and some other minor characters are intermediate.

20. Deutzia densiflora Rehder. See p. 12.

21. Deutzia albida Batalin in Act. Hort. Petrop. XIII. 97 (1893).

Deutzia discolor, var. albida Schneider in Mitt. Deutsch. Dendr. Ges. XIII. 183 (1904).

Kansu: banks of the river Pai-shui between Lidshapu and Kwantin, G. Potanin (ex Batalin).

I have not seen the type specimen, but according to the description the species differs from $D$. discolor in so many points that I cannot follow Schneider in referring it to that species as a variety.

22. Deutzia longifolia Franchet. See p. 13.

Subsect. 4. GRANDIFLORAE Rehder, n. subsect.

Chiefly characterized by the 1-3-flowered inflorescence borne at the end of short leafy branchlets, by the partly superior ovary, the lanceolate calyx-teeth and the re-curved teeth of the filaments.

23. Deutzia grandiflora Bunge in Mém. Sav. Etr. Acad. Sci. St. Pétersbourg II. 104 (Enum. Pl. Chin. Bor.) (1832). - Maximowicz in Mém. Acad. Sci. St. Pétersbourg, sér. 7, X. No. XVI. 30 (1867).

D. Baroniana, var. insignis Pampanini in Nuov. Giorn. Bot. Ital. n. ser. XVII, 282 (1910).

Chihli: A. Bunge; Kalgan road near Pekin, October 5, 1905, J. G. Jack; Weichang, 1910, W. Purdom (No. 16). Hupeh: April 1901, E. H. Wilson (Veitch Exped. No. 1870); Ou-tan-shan, C. Silvestri (ex Pampanini).

The Hupeh specimens differ from the type in their narrower leaves and in the elongated and somewhat wavy rays of the hairs of the under side of the leaves, so that the tomentum appears more villose and not as closely appressed as in the type; in this respect it approaches the following variety. I have seen no specimen of Pampanini's var. insignis, but from his description it appears not to be different from typical $D$. grandiflora.

Deutzia grandiflora, var. Baroniana Rehder, n. var.

Deutzia Baroniana Diels in Bot. Jahrb. XXIX. 372 (1901).

Northern Shensi: Tui-kia-shan, G. Giraldi (No. 1656 ex Diels); Shan-geus, Lao-y-san, May 19, 1899, G. Giraldi (No. 4522).

Differs from the type chiefly in the heteromorphous and thinner grayish green pubescence of the under side of the narrower leaves which are usually broadly cuneate at the base; the stellate hairs have only 5-7 rays mostly with a central ray, not 7-9 without central ray as in the type. The flowers of No. 4522 agree with those of the type. I cannot follow Schneider in referring the Shensi plant to D. grandiflora, var. glabrata Maximowicz; the pubescence of the latter is homomorphous, the hairs having 6-9 short rays and are only sparingly distributed over the lower surface, not touching each other.

Deutzia grandiflora, var. $\beta$ minor Maximowicz in Mém. Acad. Sci. St. Pétersbourg, sér. 7, X. No. XVI. 31 (1867). 
Mongolia: Tatarinoff (ex Maximowicz). Chili: near Kalgan, Ladyshinski (ex Maximowicz).

Of this variety I have seen no specimen; it differs according to Maximowicz in its smaller leaves and flowers and shorter styles.

Deutzia grandiflora, var. $\gamma$ glabrata Maximowicz in Mém. Acad. Sci. St.Pétersbourg, sér. 7, X. No. XVI. 31 (1867)

Chili: near Pekin, Tatarinoff.

24. Deutzia prunifolia Rehder, n. sp.

Frutex erectus ramulis junioribus glabris pallide fusco-brunneis, vetustioribus griseo-brunneis. Gemmae perulis circa 10 exterioribus, ovato-lanceolatis acutis, extus sparse stellato-pilosis, castaneis. Folia ovata, v. rhombico- v. ellipticoovata, acuminata, basi late cuneata, inaequaliter $\mathrm{v}$. fere dupliciter fimbriato-denticulata, dentibus minutis acuminatis, $3.5-5 \mathrm{~cm}$. longa et $1.5-3 \mathrm{~cm}$. lata, flavoviridia, concoloria, supra pilis 4-5-radiatis laxe conspersa, subtus glabra pilis simplicibus ad costam mediam et paucis ad basin costarum lateralium exceptis, interdum facie pilis rarissimis 5-radiatis instructa, utrinsecus costis 5-7 supra impressis subtus elevatis; petioli glabri, 3-5 mm. longi. Flores desunt. Capsulae 1-3 in apice ramulorum, solitariae pedicellis glabris gracilibus circa $1 \mathrm{~cm}$. longis, binae v. ternae pedunculo $1-1.5 \mathrm{~cm}$. longo insidentes pedicellis circa $5 \mathrm{~mm}$. longis; capsula (immatura) depresso-globosa, circa $5 \mathrm{~mm}$. diam., extus glabra, semisupera, apice ovarii et basi stylorum 3-4 sparse stellato-pilosa, dentibus calycis lanceolatis reflexis tubum saltem aequilongis partim persistentibus.

Korea: Ping Yang, September 18, 1905, J. G. Jack (Herb. Arnold Arboretum).

Closely related to $D$. grandiflora Bunge, and particularly to its glabescent variety $\gamma$ glabrata which, however, differs in the shorter petioles, the shorter scarcely acuminate teeth of the leaves, and their less prominent venation, in the hairs of the upper surface having usually 5-6 rays and those of the lower surface 6-8 rays and also in the shorter peduncles and pedicels. Deutzia hamata Koehne, which is similar in foliage, differs in the peculiar development of the pubescent calyx.

25. Deutzia hamata Koehne in Bot. Jahrb. XXXIV. No. LXXV. 37 (1905).

Shantung: Laushan Mts., Zimmermann (Nos. 335, 348 ex Koehne).

This species is well marked by the peculiar development of the calyx which has the margin incurved forming a hollow ring open toward the apex of the ovary and partly covering it; the spreading lanceolate calyx-lobes are borne on the outside of the ring.

Subsect. 5. COREANAE Rehder, n. subsect.

Distinguished from all the other Deutzias by the solitary or rarely two flowers appearing from leafless buds and borne on short stalks hidden by the bud-scales; calyx-tube ovoid, truncate at the apex with short triangular lobes; styles slender, 3 ; leaves on both sides sparingly covered with hairs with 4-5 rays.

26. Deutzia coreana Léveillé in Fedde, Rep. Sp. Nov. VIII. 283 (1910).

Korea: Diamant Mts., June 1908, U. Faurie (No. 364); Pouck Han, Seoul, September 25, 1905, J. G. Jack.

The leaves are sparingly furnished on both sides with stellate hairs, those of the upper side having generally 4 , those of the under side generally 5 rays; the capsule is about $4 \mathrm{~mm}$. long, distinctly longer than broad and thinly covered with stellate hairs having 6-7 rays; styles $3.10 \mathrm{~mm}$. long.

Sect. II. MESODEUTZIA Schneider in Mitt. Deutsch. Dendr. Ges. XIII (1905).

27. Deutzia mollis Duthie. See p. 13.

28. Deutzia corymbosa R. Brown apud Royle, Ill. Bot. Himal. 216, t. 46, fig. 2 
(1839). - Maximowicz in Mém. Acad. Sci. St. Pétersbourg, sér. 7, X. No. XVI. 33, fig. 14-17 (1867). - Clarke in Hooker f. Fl. Brit. Ind. II. 406 (1878).u

Deutzia corymbosa R. Brown ex Wallich, Cat. No. 3652 (nom. n dum) (1828).

Deutzia parviflora, var. corymbosa Franchet in Jour. de Bot. X. ${ }^{2} 83$ (1896).

Deutzia corymbosa, var. typica Schneider in Mitt. Deutsch. Dendr. Ges. XIII. 184 (1904); Ill. Handb. Laubholzk. I. 382, fig. 244 g-i (1905).

Sh en si: Ki-fon-shan, near Pao-ki-scen, G. Giraldi 'ex Engler).

I have seen no specimens of this species from China, and it seems doubtful whether the specimen from Shensi really belongs here.

Deutzia corymbosa, var. yunnanensis Franchet in Jour. de Bot. X. 283 (1896), Yunnan (ex Franchet).

This variety, incompletely described by Franchet without citation of specimens, probably does not belong to $D$. corymbosa; it is possibly closely related to $D$. rubens Rehder.

29. Deutzia parviflora Bunge in Mém. Sav. Etr. Acad. Sci. St. Pétersbourg II. 105 (Enum. Pl. Chin. Bor.) (1832). - Maximowicz in Mém. Acad. Sci. St. Pétersbourg, sér. 7, X. No. XVI. 33, t. 3, fig. 18-23 (1867). - Sargent in Gard. and For. I. 363, fig. 57 (1888).

Deutzia parviflora, $\beta$ amurensis Regel in Mem. Acad. Sci. St. Pétersbourg, sér. 7, IV. No. IV. 63, t. 5, fig. 7-14 (1861); in Gartenfl. XI. 278, t. 370, fig. 4-12 (1862).

Deutzia parviflora, a Bungei Franchet in Jour. de Bot. X. 283 (1896).

Deutzia parviflora, $\beta$ mongolica Franchet, 1. c.

Deutzia corymbosa, var. parviflora Schneider in Mitt. Deutsch. Dendr. Ges. XIII. 184 (1904); Ill. Handb. Laubholzk. I. 382, fig. 244 k-m (1905).

Chili: Weichang, 1910, W. Purdom (No. 40). Mandshuria: river Sutár, July. 1895, V. Komarov (No. 836); without locality, 1891, S. Korshinsky; mts. east of Harbin, August 31, 1903, C. S. Sargent. Korea: Fusan, May 1906, U. Faurie (No. 361).

Franchet's variety $\beta$ mongolica does not seem sufficiently distinct to be separated as a variety; of the specimens named above only Purdom's No. 40 with simple hairs along the midrib beneath would belong to this variety; all the others must be referred to his var. a Bungei, though I never saw a specimen with perfectly glabrous leaves; they all have at least a few hairs, sometimes nearly imperceptible, on the lower surface.

Deutzia parviflora, var. musaei Lemoine in Jour. Hort. Soc. France, sér. 4, III. 303 (1902).

This variety, described from specimens cultivated at the Jardin des Plantes at Paris, differs from the type chiefly in the larger more pointed leaves and denser inflorescence with fewer creamy white flowers.

30. Deutzia micrantha Engler in Bot. Jahrb. XXXVI. Beibl. No. LXXXII. 51 (1905).

Shen si: Tsin-ling-shan, July 1900, G. Giraldi (No. 7179); In-kia-p'u, G. Giraldi (No. 2526, ex Engler).

Closely related to $D$. parviflora Bunge, from which it differs in the much smaller flowers, in the shape of the inflorescence, and in the stellate hairs of the under side of the leaves being more numerous and having generally 8-10 rays. 'The inflorescence much resembles in its mode of branching that of $D$. mollis Duthie, the partial inflorescence being rather dense and borne on elongated and remote branchlets. 
31. Deutzia glabrata Komarov in Act. Hort. Petrop. XXII. 433 (1903).

Deutzia glaberrima Koehne in Bot. Jahrb. XXXIV. Beibl. No. LXXV. 38 (1904).

Deutzia Fauriei Léveille in Fedde, Rep. Nov. Sp. VIII. 283 (1910).

Korea: Diamond Mts., June 24, 1906, U. Faurie (No. 360). Pomasa, May 21, 1906, U. Faurie (No. 362). Shantung: Laushan Mts., Zimmermann (No. 349 ex Koehne). Also in Mandshuria (ex Komarov).

32. Deutzia rubens Rehder. See p. 13.

33. Deutzia hypoglauca Rehder, n. sp.

Frutex ramulis gracilibus glabris rubro-fuscis, annotinis peridermate solubili. Gemmae perulis lanceolatis glabris obscure castaneis. Folia membranacea, ovatooblonga v. elliptico-oblonga v. oblonga, acuminata, basi cuneata v. rotundata, argute minuteque serrulata, 4-6 cm. longa et $1.5-2.5 \mathrm{~cm}$. lata, supra flavo-viridia, pilis paucis plerumque 4-radiatis conspersa, subtus glauca, glaberrima, utrinsecus 5-6-costata; petioli glaberrimi, 2-4 $\mathrm{mm}$. longi. Cyma pluriflora, pedunculata, ebracteata, glabra, pedicellis gracilibus, 5-7 mm. longis, apice tantum sparse stellato-pilosis; calycis lobi late ovati, obtusi, dimidium tubum laxe stellato-pilosum vix superantes; petala obovata, alba, $9 \mathrm{~mm}$. longa, extus sparse stellato-pilosa; stamina petalis paullo breviora, exteriora filamentis apice bidentatis dentibus antheram paullo superantibus, interiora filamentis lineari-oblongis apice leviter bidentata antheram paullo supra medium faciei interiori affixam gerentibus; styli 3 , staminibus paullo breviores.

Hu peh: E. H. Wilson (Veitch Exped.. No. 1919, Herb. Arnold Arboretum).

From all the other species of this group this is easily distinguished by the glaucous and quite glabrous under side of the leaves.

CARDIANDRA Sieb. and Zucc.

Determined by ALFrEd REHDER.

Cardiandra sinensis Hemsley in Gard. Chron. ser. 3, XXXIII. 82 (1903).

Kiangsi: Kuling, wet shady places, common, alt. 1200 m., July 30 , 1907 (No. 1545).

Wilson's specimen agrees exactly with Faber's specimen from Ningpo. Hemsley (Jour. Linn. Soc. Bot. XXIII. 278) cites in 1887 a specimen from Kiangsi collected by Forbes under $C$. alternifolia Siebold \& Zuccarini, but in his description of $C$. sinensis in 1903 he only cites Faber's specimen from Ningpo and Wilson's No. 2426 (Veitch Exped.) from Hupeh without mentioning the Kiangsi specimen. There can be, however, little doubt that Faber's Kiangsi specimen and also David's specimen from Kiangsi cited by Franchet as C. alternifolia (Pl. David. I. 126), belong to the same species as Wilson's specimen from Kiangsi, namely to $C$. sinensis, and that C. alternifolia does not occur in China. 


\section{HYDRANGEA L.}

\section{Determined by ALFred ReHDer.}

Hydrangea umbellata Rehder, n. sp.

Frutex metralis v. paullo altior ramulis fusco-purpureis, novellis crispule pubescentibus, annotinis cortice laevi sine lenticellis, demum in lamellas tenues solubili. Folia membranacea, oblongo-lanceolata v. obovata, acuminata, basi cuneata, $5-9 \mathrm{~cm}$. longa et $2-3 \mathrm{~cm}$. lata, denticulato-serrata basi excepta, supra luteo-viridia, glabra costa sparse villosa excepta, subtus glaucescentia, sparse ad venas densius strigillosa et in axillis venarum barbata; petioli crispule pubescentes, 6-13 $\mathrm{mm}$. longi. Inflorescentia umbelliformis multiflora, in apice ramulorum sessilis, crispe pubescens, plerumque 5-radiata, pedicellis circa $5 \mathrm{~mm}$. longis; flores fertiles desunt; flores radiantes steriles graciliter pedicellati, persistentes, 4-sepali sepalis late ellipticis v. subrotundatis, crassiusculis, plus minus dentatis, $2-2.5 \mathrm{~cm}$. longis et interdum ad $2.5 \mathrm{~cm}$. latis. Capsula (immatura) semisupera, cum stylis $6 \mathrm{~mm}$. longa, parte superiore libera paullo longiore quam tubus calycis pilis crispulis sparsis adspersi; styli 3, partem liberam capsulae subaequantes, sat graciles; semina late elliptica, exalata.

Kiangsi: Kuling, thickets, common, alt. 1200 m., July 29, 1907 (No. 1605).

Closely related to $H$. scandens De Candolle ( $H$. virens Siebold), which differs chiefly in its smaller sparingly toothed leaves, in the few-flowered cymes with the sterile flowers with three deciduous entire sepals, in the smaller capsules with longer styles and in its lax habit with very slender often drooping branches.

Hydrangea Davidii Franchet in Nouv. Arch. Mus. Paris, sér. 2, VIII. 227 (Pl. David. II. 44) (1885).

Western Szech'uan: Mupin, thickets, alt. 1800-2250 m., June and October 1908 (No. Ir59), alt. 2400-2700 m., October 1910 (No. 4343); alt. 1500-1800 m., Nov. 1908 (No. I249); Wa-shan, thickets, alt. 1500-2100 m., June and November 1908 (No. II59); without locality, alt. 1500-2400 m., July 1903 (Veitch Exped. No. 3563).

Wilson's specimens differ from Franchet's description slightly in having usually 4 sepals and in the leaves being up to $6 \mathrm{~cm}$. broad. The capsule, which is not described by Franchet, is subglobose, $2-3 \mathrm{~mm}$. in diameter, the free part longer than the tube of the calyx; the seeds are broadly elliptic, wingless, scarcely $1 \mathrm{~mm}$. long and light yellowish brown.

Hydrangea paniculata Siebold in Nov. Act. Acad. Leop. Carol. XIV. pt. ii. 690 (Syn. Hydrang.) (1829). 
Kiangsi: Kuling, abundant, side of streams, July 27, 1907 (No. I6or).

This is as far as I know the first time that $H$. paniculata has been found in China. The specimen differs very little from the Japanese plant; the serratures of the leaves are strongly incurved, the veins are yellow on the upper side and strigosely pubescent below, while in the Japanese specimens the leaves are nearly glabrous and the teeth are slightly spreading.

Hydrangea hypoglauca Rehder, n. sp.

Frutex ad $3 \mathrm{~m}$. altus ramulis junioribus castaneo-purpureis glabris, lenticellis inconspicuis institutis. Folia ovata v. ovato-oblonga, acuminata, basi rotundata $\mathrm{v}$. late cuneata, argute mucronulatoserrulata, supra flavo-viridia, glabra nervis strigosis flavescentibus exceptis, subtus glauca (sub lente dense papillosa), ad nervos dense pubescentia ceterum glabra, 7-10 $\mathrm{cm}$. longa et $2.5-4.5 \mathrm{~cm}$. lata; petioli graciles, parce pilosi, $2-3 \mathrm{~cm}$. longi. Cyma laxa, convexa, radiis 5-7 decussatis distantibus composita, strigosa; flores radiantes 2-3 cm. diam., sepalis 3-4 late ovalibus v. obovatis albis; calycis dentes florum fertilium ovato-triangulares, acuminata; petala alba, ovatooblonga, concava, apice cucullata, $2 \mathrm{~mm}$. longa; stamina inaequalia, breviora petalis subaequilongis, longiora $3 \mathrm{~mm}$. longa; styli 3 , erecti; ovarium semisuperum. Capsulae maturae desiderantur.

Western Hupeh: A. Henry (No. 6056, type); north and south of Ichang, thickets, alt. 900-1800 m., June 1907 (No. 2397); no locality, June 1901 (Veitch Exped. No. 1271).

Allied to Hydrangea xanthoneura Diels which differs chiefly in the more or less elliptic leaves being green on the under side with strigose veins and in the triangular obtusish sepals.

Hydrangea xanthoneura Diels in Bot. Jahrb. XXIX. 373 (1900).

Szech'uan: Nanch'uan, Ching-lung-tsui, August 9, 1891, A. von Rosthorn (No. 354, type); Wa-shan, thickets, alt. 1800-2600 m., July and November 1908 (Nos. 2409, flowers, and 1354, fruits); Tachien-lu, thickets, alt. 2400-2700 m., October 1910 (No. 439I); Pan-lan-shan, west of Kuan Hsien, thickets, alt. 2200 m., August 1910 (No. 4484). Mt. Omei, July 1904 (Veitch Exped. Nos. 4899 and 4900).

This is apparently a very variable species and closely related to $H$. Bretschneideri from which it can be separated only by the glabrous or glabrescent under side of the leaves more or less cuneate at the base. In the type the under side of the leaves is glabrous or nearly glabrous except the strigose veins which are yellowish on the upper side; the branchlets are bright reddish brown with the bark without lenticels and soon separating into thin flakes. Wilson's Nos. 4391 and 4899 seem nearest to the type. No. 4484 is also near the type, except that it has the leaves loosely pubescent beneath, while the other numbers of Wilson differ in their large foliage, 
the leaves attaining a length of 15-20 cm. with the petioles $4 \mathrm{~cm}$. long and the inflorescence measuring $25 \mathrm{~cm}$. in diameter.

Hydrangea xanthoneura, var. Wilsonii Rehder, n. var.

A typo recedit ramulis hornotinis griseo-flavescentibus, annotinis griseis v. avellaneis lenticellis pallidis instructis cortice adhaerente et foliis junioribus subtus sparse adpresse pubescentibus. Arbor ad $5 \mathrm{~m}$. alta.

Western Szech'uan: Ta-p'ao-shan, northeast of Tachien-lu, woodlands, alt. 2400-2800 m., July 3, 1908 (No. 2407, type); Panlan-shan, west of Kuan Hsien, thickets, alt. 2200 m., June 26, 1908 (No. 2410); Wa-ssu country, Wên-chuan Hsien, thickets, alt. 16002400 m., July 1908 (No. 2408).

The color and behavior of the bark would seem to afford good specific differences, if it were not for the following specimens which are intermediate in this respect between the type and the variety, but are apparently closer to the variety.

Hydrangea xanthoneura, var. glabrescens Rehder, n. comb.

Hydrangea serrata Koehne, Deutsch. Dendr. 189 (not De Candolle) (1893).

Hydrangea Bretschneideri, var. glabrescens Rehder in Bailey, Cycl. Am. Hort. II. 784 (1900); in Mitt. Deutsch. Dendr. Ges. XII. 121 (1903).

A typo recedit foliis minoribus, tenuioribus et plerumque angustioribus, saepe grossius serratis, venis supra non flavidis, subtus fere glabris v. sparse pubescentibus nec strigosis.

Seed collected by Dr. E. Bretschneider near Pekin and introduced into cultivation: Hort. Bot. Berol.; E. Koehne, Herb. Dendr. (No. 113); Arnold Arboretum, in Herb. Arnold Arboretum.

It is with some hesitation that I refer this variety to $H$. xanthoneura, but if the pubescence is to be considered the chief distinguishing character between this species and $H$. Bretschneideri, it must be referred to the former.

Western Szech'uan: Mupin, thickets, alt. 1500-2500 m., June and October 1908 (Nos. II83, 1327); thickets around Tachien-lu, alt. 2100-2400 m., October 1908 (No. r347); near Tachien-lu, 2700-3600 m., A. E. Pratt (No. 285). Western Hupeh: Hsing-shan Hsien, thickets, alt. 1500-1800 m., July 1907 (No. 2398); no locality, June 1901 (Veitch Exped. No. 2184). Yunnan: Mengtze, alt. 2700 m., A. Henry (No. 10235).

Hydrangea pubinervis Rehder, n. sp.

Frutex ad $3 \mathrm{~m}$. altus ramulis junioribus glabrescentibus purpureis, vetustioribus castaneis lenticellis sparsis instructis. Folia membranacea, alte elliptica, acuminata, basi late cuneata, grossius ser- 
rato-dentata, supra flavo-viridia, glabra v. fere glabra nervis strigosis exceptis, subtus pallidiora, tota facie crispulo-villosa ad nervos pilis flavidis adpressis dense obtecta, 6-9 cm. longa et $3.5-4.5 \mathrm{~cm}$. lata; petioli graciles, 1.5-2 cm. longi, pubescentes. Cyma fere plana, e radiis 5-7 decussatis distantibus composita, strigosa; flores radiantes circa $2.5 \mathrm{~cm}$. diam. sepalis 4 late ovalibus $\mathrm{v}$. obovatis; calycis dentes florum fertilium triangulares; petala oblongo-ovata, apice cucullata, $2 \mathrm{~mm}$. longa; stamina inaequalia, minora petalis breviora, majora petalis paullo longiora; ovarium semisuperum; stylis 3 erectis. Capsulae maturae desiderantur.

Western Szech'uan: Wa-shan, thickets, alt. 1500-2250 m., July 1908 (No. 24II).

Closely related to $H$. xanthoneura Diels which is easily distinguished by the leaves being serrulate, narrower and larger and on the under side nearly glabrous except the strigose veins.

Hydrangea Bretschneideri Dippel, var. setchuenensis Rehder, $\mathrm{n}$. var.

A typo recedit foliis majoribus ad $20 \mathrm{~cm}$. longis et $11 \mathrm{~cm}$. latis, venis saepe flavescentibus, petiolis densius pubescentibus, ramulis junioribus laxe et sparse pubescentibus, annotinis pallide brunneis lenticellis conspicuis instructis, cymis usque ad $25 \mathrm{~cm}$. diam., laxis, convexis, interdum fere paniculiformibus.

Western Szech'uan: Wa-ssu country, Wên-chuan Hsien, thickets, alt. 2300-2700 m., July and November 1908 (No. I323). Western Hupeh: Fang Hsien, rocky places, alt. 1800 m., August 1907 (No. 2399).

The Szech'uan and the Hupeh plants differ slightly; the former has the leaves generally ovate-oblong and approaches also in the somewhat darker color of the branchlets the type, while the leaves of the Hupeh plant are elliptic-oblong or oblong-obovate.

Hydrangea Bretschneideri, var. lancifolia Rehder, n. var.

A typo recedit ramulis cinereis lenticellis conspicuis instructis, foliis oblongo-lanceolatis, supra sparse strigosis, subtus tota facie dense crispulo-villosis et ad nervos strigosis, 7-12 $\mathrm{cm}$. longis et 2-3 cm. latis.

Western Szech'uan: Tachien-lu, thickets, alt. 2100-2400 m., June 1908 (No. 24I2).

This variety might possibly be considered a pubescent and narrow-leaved form of $H$. xanthoneura, since it has almost the same kind of bark as var. Wilsonii of that species. 


\section{Hydrangea Sargentiana Rehder, n. sp.}

Frutex robustus bimetralis; ramuli juniores dense villosi et excrescentiis crebris e trichomatibus basi confluentibus purpureis formatis praediti. Folia ovato-oblonga, acuminata, basi rotundata v. interdum subcordata $v$. late cuneata, inaequaliter et fere dupliciter ciliatodentata dentibus setaceo-acuminatis, $15-30 \mathrm{~cm}$. longa et $6.5-16 \mathrm{~cm}$. lata, supra obscure viridia, scabro-strigosa, subtus dense villoso-hirta, ad nervos hirto-pilosa excrescentiis purpureis intermixtis; petioli dense pilosi et excrescentiis purpureis instructi, 3-9 cm. longi. Cyma fere plana, 12-16 cm. diam., densa, dense pubescens, e radiis oppositis congestis 7-13 composita; flores radiantes graciliter pedicellati 2.5-3.5 cm. diam. albi, sepalis 4, orbiculato-obovatis integris; sepala florum fertilium late triangularia, tubo dimidio breviora; petala ovata, mox caduca, apice interdum calyptratim coherentia, $2 \mathrm{~mm}$. longa; stamina breviora petalis aequilonga, longiora circa $4 \mathrm{~mm}$. longa; styli plerumque $3 \mathrm{v}$. interdum 2. Capsula hemispherica, leviter 1012-costata, apice truncata, $3 \mathrm{~mm}$. diam.; semina elliptica, utrinque in alam brevem contracta, striata, flavo-brunnea, circa $0.7 \mathrm{~mm}$. longa.

Western Hupeh: Hsing-shan Hsien, thickets, alt. 1500-1800 m., August and December 1907 (No. 772).

Adistinct species with large and handsome foliage similar to $H$. robusta Hooker f. \& Thomson, which is easily distinguished by its strigose pubescence, ovate leaves, by the serrate sepals of the sterile flowers and the larger capsule. The allied $H$. Rosthornii Diels also differs in its strigose pubescence and ovate leaves.

Hydrangea villosa Rehder, $n$. sp.

Frutex 1-3 m. altus ramulis junioribus albido- v. fulvo-villosis angulatis. Folia elliptico- v. oblongo-lanceolata, acuminata, basi cuneata, fimbriato-denticulata dentibus setaceo-acuminatis, 10-20 $\mathrm{cm}$. longa et $3.5-6.5 \mathrm{~cm}$. lata, supra obscure flavo-viridia, scabrostrigosa pilis basi bulbosis, ad costam mediam pilis longioribus albidis instructa, subtus pilis patentibus hirto-villosis incano-tomentosa, ad nervos pilis ad $3 \mathrm{~mm}$. longis et saepe, praesertim ad costam mediam, fulvescentibus v. fulvis praedita; petioli villosi saepe pilis fulvis longis patentibus interspersis, 1-4 cm. longi. Cyma convexa, interdum plana, albido- v. fulvo-villosa, radiis oppositis 7-9 satis remotis composita; flores radiantes graciliter pedicellati, $3-4 \mathrm{~cm}$. diam., coerulescentes, sepalis 4 orbiculato-obovatis plerumque crenulatis; pedicelli florum fertilium strigosi, tubum calycis glabri v. basi tantum strigosi subaequantes, dentibus triangularibus vix dimidium tubum aequantibus; petala oblongo-ovata, acutiuscula, concava, patentia, 
$2 \mathrm{~mm}$. longa; stamina valde inaequalia, minora petalis subaequilonga, majora eis duplo longiora; styli 2, patentes, apice incrassati. Capsula hemispherica, apice truncata, leviter costata, 2.5-3 mm. diam.; semina late elliptica, utrinque in alam constricta, striata, flavido-brunnea, circa $0.6 \mathrm{~mm}$. longa.

Western Szech'uan: Wa-ssu country, Wên-chuan Hsien, thickets, alt. 1800 m., July and November 1908 (No. I227, type), alt. 12002700 m., July and November 1908 (No. I250), October 1910 (No. 4302); Pan-lan-shan, west of Kuan Hsieh, woodlands, alt. 2400 m., August 1910 (No. 4483).

Easily distinguished from allied species by its villous pubescence.

Hydrangea glabripes Rehder, n. sp.

Frutex metralis ramulis glabris v. fere glabris, vetustioribus flavogriseis. Folia lanceolata, acuminata, basi late cuneata v. rotundata, dentato-serrulata serraturis mucronulato-acuminatis, 6-12 cm. longa et 2-3 cm. lata, supra obscure flavo-viridia, satis dense strigulosa, subtus pallida, hirto-villosa costa fere glabra excepta; petioli graciles, 1.5-4 cm. longi, glabri, tantum supra in canaliculo parce pubescentes. Cyma fere plana v. leviter convexa, 8-10 cm. diam., strigosa, radiis brevibus 7-9; flores radiantes pauci, rosei, sepalis 4 , late obovatis, leviter emarginatis integris; flores fertiles rosei; calycis tubus hemisphericus, glaber ima basi excepta, dentibus triangularibus minutis; petala oblongo-ovata, $1.5 \mathrm{~mm}$. longa; stamina inaequalia, longiora $4 \mathrm{~mm}$. longa; styli 2 . Capsulae maturae desunt.

Western Hupeh: Fang Hsien, thickets, alt. 1200-1800 m., August 1907 (No. 239I).

Closely related to $H$. longipes Franchet which is chiefly distinguished by broader strigose or glabrescent leaves, strigose branchlets, longer petioles and white flowers. From all allied species $H$. glabripes differs in the leaves having a densely villous under side and at the same time a glabrous petiole and a glabrous or nearly glabrous midrib.

Hydrangea aspera D. Don, var. velutina Rehder, n. var.

Differt a typo foliis minoribus subtus densius velutino-hirtellis, floribus fertilibus sterilibusque coeruleis v. roseis minoribus, stylis plerumque 2. Folia oblongo-ovata v. ovato-lanceolata, fimbriatodenticulata, $8-12 \mathrm{~cm}$. longa et 3-5 cm. lata; petioli 1-2 cm. longi; petala, stamina, styli coerulea; flores radiantes steriles $3 \mathrm{~cm}$. diam., sepalis crenato-serratis.

Western Szech'uan: Wa-shan, thickets, alt. 1800-2400 m., July 1908 (Nos. 2405, 2403 (floribus omnibus sterilibus)); Mupin, thickets, 
alt. 1200-1500 m., June 1908 (No. 2404); Lungan Fu, thickets, alt. 1800-2700 m., August 1910 (No. 4482).

This form is probably best treated as a variety of $H$. aspera, though it shows a close relation to $H$. villosa; it lacks, however the villous and fulvous hairs of that species. In No. 2404 and 4482 the pubescence is less velutinous and approaches that of $H$. strigosa.

Hydrangea aspera, var. scabra Rehder, $n$. var.

A typo recedit praecipue foliis ovatis $v$. ovato-oblongis, basi rotundata v. subcordata, supra manifeste scabra, subtus dense velutinohirtellis, $12-18 \mathrm{~cm}$. longis et 7.5-10 $\mathrm{cm}$. latis. Capsula circa $3 \mathrm{~mm}$. diam., stylis 2.

Western Szech'uan: southeast of Tachien-lu, thickets, alt. 2400 m., October 1910 (No. 4485).

In the shape of the leaves this variety approaches somewhat $H$. Rosthornii Diels, but is easily distinguished by the nearly velutinous pubescence of the under side of the leaves and by the shorter petioles.

Hydrangea strigosa Rehder, n. sp.

H. aspera Hemsley in Jour. Linn Soc. XXIII. 272 (not D. Don) (1887). Pampanini in Nuov. Giorn. Bot. Ital. n. ser. XVII. 283 (1910).

H. aspera, f. typica Diels in Bot. Jahrb. XXIX. 375 (1900).

Frutex 2-3 m. altus, ramulis junioribus teretibus v. leviter angulatis strigosis, vetustioribus griseo-brunneis lenticellis destitutis. Folia oblonga v. oblongo-lanceolata, acuminata, basi cuneata, denticulato-serrata serraturis porrectis parvis mucronulatis, $8-23 \mathrm{~cm}$. longa et $2-6 \mathrm{~cm}$. lata, supra sparse strigosa, subtus densius strigosa, praecipue ad venas; petioli $1.5-3 \mathrm{~cm}$. longi, dense strigosi. Cyma convexa, radiis $5-7$, dense strigosa; flores radiantes graciliter pedicellati, sepalis late ovalibus plerumque mucronulatis integris v. sparse serrulatis; flores fertiles albi; sepala triangularia, calycis dimidium tubum parce strigosum vix aequantia, glabra $\mathrm{v}$. fere glabra; petala ovato-oblonga, $2 \mathrm{~mm}$. longa; stamina longiora circa $6 \mathrm{~mm}$. longa, breviora dimidio breviora; styli 2. Capsula hemispherica, truncata, $3 \mathrm{~mm}$. alta, costata; semina late elliptica, utrinque subito in alam contracta, striata, $0.6 \mathrm{~mm}$. longa, flavo-brunnea.

Western Hupeh: north and south of Ichang, thickets, alt. 500$1200 \mathrm{~m}$., August and December 1907 (No. 765, type): Hsing-shan Hsien, thickets, alt. 900-1500 m., August and December 1907 (Nos. 773, 2394); Patung Hsien, thickets, alt. 1200-1500 m., August 1907 (Nos. 2392, 2395); Fang Hsien, thickets, alt. 1200-1800 m., August 1907 (No. 2390, with all the flowers sterile); Packang, 1901 (Veitch 
Exped. No. 1473); South Wushan, 1901 (Veitch Exped. No. 2446); without locality, 1901 (Veitch Exped. No. 2527); A. Henry (No. 1083). Western Szech'uan: Mt. Omei, 1904 (Veitch Exped. No. 4902 with all the flowers sterile); Nanch'uan, Shan-tzu-p'ing, A. von Rosthorn (No. 299).

Closely related to $H$. aspera $\mathrm{D}$. Don which chiefly differs in the fimbriate-denticulate leaves being on the under side on the veins and veinlets covered with a villosehirtellous, not appressed strigose pubescence and in the larger capsules with usually three styles. The difference in pubescence and serration, serrulate, with the teeth pointing forward in $H$. strigosa, and denticulate or dentate with spreading teeth in $H$. aspera, seems to distinguish clearly the Chinese from the Himalayan plant of which I have seen Wallich's No. $440 \mathrm{~B}$; the pubescence of that specimen agrees well with Don's original description "foliis . . . subtus dense cano-tomentosis " and Clarke's description "under surface with gray woolly hairs," terms which hardly could be applied to the strigose pubescence of the Chinese plant. In size and shape of foliage the Chinese plant seems exceedingly variable, and the following forms pass gradually into each other.

Hydrangea strigosa, var. macrophylla Rehder, n. comb.

H. aspera, var. macrophylla Hemsley in Jour. Linn. Soc. XXIII. 273 (1887). -

Diels in Bot. Jahrb. XXIX. 375 (1900).

Western Hupeh: A. Henry (Nos. 2083, 6477); Fang Hsien, thickets, alt. 1300 m., August 1907 (No. 57I); Hsing-shan Hsien, thicket, alt. 900-1200 m., August and December 1907 (No. 757). Western Szech'uan: Mt. Omei, July 1904 (Veitch Exped. No. 4902); Nanch'uan, Chang-kou, September 18, 1891, A. von Rosthorn (No. 953).

The leaves of this form are sometimes $28 \mathrm{~cm}$. in length and $11 \mathrm{~cm}$. in width and are generally ovate-lanceolate or sometimes ovate-oblong and nearly rounded at the base. This form passes gradually into the type, and some specimens enumerated under the type, as Wilson's Nos. 2394 and also No. 773 and Henry's No. 1083, with leaves $22 \mathrm{~cm}$. long and $6.5 \mathrm{~cm}$. broad, might perhaps be referred to var. macrophylla, but the leaves are comparatively narrow and cuneate at the base.

Hydrangea strigosa, var. sinica Rehder, n. comb.

H. aspera, var. є sinica Diels in Bot. Jahrb. XXIX. 375 (1900).

Western Hupeh: A. Henry (No. 185); Nan-t'o, A. Henry (No. 2206). Western Szech'uan: Nanch'uan, Ma-fou-lin-p'o, August 26, 1901, A. von Rosthorn (No. 629).

Differs in its oblanceolate or oblong-obovate leaves rarely exceeding $10 \mathrm{~cm}$. in length, the leaves having generally their greatest width above the middle, not below as in the other forms.

Hydrangea strigosa, var. angustifolia Rehder, n. comb.

H. aspera var. $\zeta$ angustifolia Diels l. c. 
Western Szech'uan: Wang-t'ien-ling, August 9, 1891, A. von Rosthorn (No. 1168, type). Hupeh: Changyang Hsien, thickets, alt. 30-60 m., September 1907 (Nos. 2393, 2396).

Wilson's No. 2396 with the leaves $23 \mathrm{~cm}$. long and $3.7 \mathrm{~cm}$. broad approaches var. macrophylla, but on account of the narrowness of the leaves it finds its place perhaps better here.

Hydrangea Rosthornii Diels in Bot. Jahrb. XXIX. 374 (1900).

Western Szech'uan: Nanchuan, Ya-chih-pa, August 1891, A. von Rosthorn (No. 471, type); Wa-shan, thickets, alt. 1500-2400 m., July, September and November 1908 (Nos. II56, I348, I372, 2414); Tachien-lu, thickets, alt. 1800-2500 m., July and October 1908 (No. I365), October 1910 (No. 4337); Mupin, thickets, alt. 2400 m., October 1910 (No. 434I); Mt. Omei, July 1904 (Veitch Exped. No. 4903).

The close relationship of this species with $H$. robusta Hooker f. \& Thomson is still more evident in Wilson's specimens than in the type specimen; the leaves of Wilson's specimens are larger, the largest measuring $25 \mathrm{~cm}$. in length and $17 \mathrm{~cm}$. in width, the longest petiole is $20 \mathrm{~cm}$. long and in some specimens the sterile flowers have strongly toothed sepals. It is also closely related to $H$. longipes Franchet, which is chiefly distinguished by its smaller and thinner, coarsely serrate leaves, less densely strigose or glabrescent beneath.

Hydrangea longipes Franchet in Nouv. Arch. Mus. Paris, sér. 2, VIII. 228 (Pl. David. II. 45) (1885).

Hydrangea ( $\$$ Calyptranthe) longipes Hemsley in Jour. Linn. Soc. XXIII. 273 (1887).

Hydrangea aspera, var. a longipes Diels in Bot. Jahrb. XXIX. 374 (1900).

Hydrangea (Calyptranthe) Hemsleyana Diels l. c. 376 (1900). - Pampanini in Nuov. Giorn. Bot. Ital. n. ser. XVII. 284 (1910).

Western Szech'uan: Mupin, June 1869, P. David; Mupin, thickets, alt. 1800 m., July 1908 (No. 2406); alt. 1500-2100 m., October 1910 (No. 4342); Wa-ssu country, Wên-chuan Hsien, thickets, alt. 1100-2100 m., July 1908 (No. 2400); Hsing-shan Hsien, thickets, alt. 1200-1800 m., July 1808 (No. 2401); Wa-shan, thickets, 1800-2400 m., July 1908 (No. 24I3); northeast of Sungpan, thickets, alt. 18002200 m., October 1910 (No. 4330); Lungan Fu, alt. 1800-2400 m., August 1910 (No. 448I); Nanch'uan, A. von Rosthorn (No. 1931). Western Hupeh: Chang-lo Hsien, cliffs and thickets, alt. 13001500 m., July 1907 (No. 2402); north and south of Ichang, thickets and rocky places, alt. 1200-1800 m., June and November 1907 (No. 580); Patung, May 1901 (Veitch Exped. No. 1213); without locality, August 1901 (Veitch Exped. No. 2514); A. Henry (Nos. 5839 A, $5839 \mathrm{~B})$. 
$H y d r a n g e a$ longipes is closely related to $H$. Giraldii Diels and also to $H$. robusta Hooker f. \& Thomson as Franchet has already stated, and some of the specimens, as Wilson's No. 580, which has rather densely pubescent and large leaves, seem somewhat intermediate. Hydrangea longipes Franchet and $H$. longipes Hemsley are identical; the apparent discrepancies in the descriptions do not exist in reality. First it is to be stated that $H$. longipes Hemsley does not belong in the section Calyptranthe where Hemsley placed it, apparently misled by the fact that the petals occasionally cohere at the apex, but this may happen in almost all species of the subsection Asperae, which does not differ in the structure of its flowers from Calyptranthe. The description of Franchet contains some misleading inaccuracies; the flowers have 10 stamens and 2 styles, not 5 stamens and 3 styles as Franchet describes them, and the leaves of at least part of the specimens collected by David attain a length of four inches, while Franchet says "folia vix ultra-pollicaria." The only difference I can find between Franchet's and Hemsley's specimens is the somewhat slighter pubescence of the latter, the leaves being sometimes nearly glabrous. A form based on No. 846 of C. Silvestri from the mountains of Chiayuen-kou, western Hupeh, with the radiant flowers smaller and greenish has been described by Pampanini as H. Hemsleyana, var. Pavoliniana (Nuov. Giorn. Bot. Ital. n. ser. XVII. 284 [1910]).

\section{Hydrangea anomala D. Don, Prodr. Fl. Nepal. 211 (1825).}

Hydrangea altissima Wallich, Tent. Fl. Nepal. t. 50 (1826).

Hydrangea glabra, Hayata in Jour. Coll. Sci. Tokyo, XXV. 89, t. 6 (Fl. Mont. Formos.) (1908).

Western Hupeh: north and south of Ichang, common, alt. 12001800 m., May and October 1907 (No. 49r, in part); Packang, July 1901 (Veitch Exped. No. 894); A. Henry (No. 6511). Western Szech'uan: Wa-shan, woodlands, alt. 1800-2500 m., June and October 1908 (No. 49r, in part); Mt. Omei, July 1904 (Veitch Exped. No. 4901); Nanch'uan, Yang-yii-ping, A. von Rosthorn (No. 51); South Wushan, A. Henry (Nos. 5557, 5658). Formosa: Mt. Morrison, $T$. Kawakami \& U. Mori (No. 1723 ex Hayata).

I have been unable to detect in Hayata's description and plate any character by which to distinguish his $H$. glabra from $H$. anomala.

\section{SYNOPSIS OF THE CHINESE SPECIES OF HYDRANGEA.}

As the determination of the copious material collected by Wilson of this genus has necessitated a study of all the Hydrangeas of China and the adjacent parts of Asia, it may be useful to place the results of this study permanently on record in the shape of a synopsis of all the Chinese species of Hydrangea.

\section{KEY TO THE SPECIES.}

* Semina exalata $\nabla$. utrinque in alam protracta; petala apice soluta, patentia; frutices erecti raro scandentes ramulis annotinis medulla alba solida ampla.

Sect. I. EUHYDRANGEA.

† Ovarium semisuperum; capsula ovoidea apice in stylos plerumque 3 attenuata; stamina petala vix v. paullo superantia, subaequalia. 
‡ Semina exalata v. alis brevissimis instructa; cyma plana, rarius convexa; petala plerumque tarde decidua, sub anthesi reflexa.

Subsect. 1. PETALANTHAE.

Cyma basi foliis suffulta; pars libera capsulae tubo calycis longior; folia denticulata v. denticulata-serrata.

Cyma umbellam sessilem formans (rarius ramulis oppositis remotis simulque foliis glabris); capsula ovoidea longior quam lata; petala obovata.

Folia glabra, subtus viridia, chartacea $\nabla$. coriacea; flores radiantes pauci v. deficientes . . . . . . . . 1. H. chinensis.

Folia subtus glaucescentia sparse ad venas densius pubescentia; cyma manifeste umbelliformis . . . . . . 2. H. umbellata.

Cyma e ramulis oppositis plus minus remotis composita; folia ad venas saltem pubescentia; flores fertiles coerulei; petala oblongo-obovata v. lanceolata.

Sepala anguste lanceolata; petala lanceolata; styli recti v. leviter apice curvati; capsula subglobosa, absque styli latior quam longa . . . . . . . . . . 3. H. Davidii.

Sepala triangulari-ovata; petala obovato-oblonga; styli apice revoluti; folia plerumque oblanceolato-oblonga; capsula ovoidea, absque stylis paullo longior quam lata . . . . 4. H. yunnanensis.

Cyma pedunculata aphylla; pars libera capsulae tubo calycis brevior, rarius aequilonga; folia argute serrata; flores fertiles coerulei v. rosei.

Folia utrinque et ramuli strigillosa pilis basi bulbosis; flores radiantes disepali pauci . . . . . . . 5. H. Moellendorfii.

Folia utrinque glabra v. supra sparse pilosa et subtus secus venas villosa; ramuli glabri; flores radiantes quadrisepali.

6. H. opuloides.

$\ddagger \ddagger$ Semina utrinque in alam protracta; flores fertiles albi; cyma corymbiformis et convexa v. paniculiformis; petala cito decidua.

Subsect. 2. HETEROMALLAE.

Inflorescentia manifeste paniculata; folia subtus ad venas tantum pubescentia v. glabrescentia ........ 7. H. paniculata. Inflorescentia cymosa plerumque convexa.

Folia subtus glabrescentia, ad venas tantum $v$. interdum ad venulas sparse pubescentia.

Folia subtus glauca, sub lente dense papillosa, ad venas pilis sericeis dense obtecta, basi rotundata . . . . 8. H. hypoglauca.

Folia subtus pallide viridia sine papillis, ad venas strigosa, basi plus minus attenuata . . . . . . 9. H. xanthoneura.

Folia subtus tota facie pubescentia.

Folia subtus pubescentia tantum.

Folia subtus ad costam mediam venasque dense pilis flavidis adpressis obtecta, ceterum laxe villoso-strigosa, elliptica, grossius serrata . . . . . . . . 10. H. pubinervis. Folia subtus cinereo-villosa, plerumque ovato-oblonga, denticulato-serrulata ......... 11. H. Bretschneideri.

Folia subtus dense albo-tomentosa, denticulato-serrulata.

12. H. mandarinorum.

†† Ovarium totum inferum; capsula hemispherica $v$. turbinata stylis plerumque duobus. . . . . . . . . . Subsect. 3. ASPERAE. ‡ Ramuli petiolique et saepe costa subtus pilis longis patentibus instructa $\mathrm{v}$. tomentosa. 
Pubes ramulorum petiolorum costarum subtus trichomatibus carnosis, aculeiformibus apice fissis plerumque purpureis crebris interspersa; folia ad $25 \mathrm{~cm}$. longa, basi plerumque rotundata $\mathrm{v}$. subcordata.

Pubes tantum pilosa v. tomentosa.

13. H. Sargentiana.

Capsula et sepala utrinque tomentosula; folia oblongo-lanceolata, ad $20 \mathrm{~cm}$. longa, supra scabra, subtus ad costas tomentosa.

14. H. longifolia.

Capsula sepalaque glabra.

Frutex scandens; folia oblongo-ovata, utrinque subtus densius scabro-pilosa . . . . . . 15. H. Kawakamii.

Frutices erecti.

Folia basi cuneata, denticulato-serrulata, subtus dense cinereovillosa; petioli foliorum superiorum $1.5-3 \mathrm{~cm}$. longi

16. H. villosa.

Folia basi rotundata $\nabla$. subcordata, serrata, subtus hirto-villosa, petioli pilis fulvis instructi omnes $3-6 \mathrm{~cm}$. longi.

¥t Ramuli petiolique strigosi v. glabri.

17. H. fulvescens.

Folia serrata v. denticulata; frutices erecti.

Folia subtus hirto-villosa.

Ramuli petiolique glabra; folia anguste lanceolata, serrulata, $2-3 \mathrm{~cm}$. lata . . . . . . . . . 18. H. glabripes.

Ramuli petiolique dense strigosa; folia oblongo-lanceolata v. lanceolata, rarius ovato-oblonga v. ovata, fimbriato-denticulata, 4-12 cm. lata. . . . . . . . . . 19. H. aspera.

Folia subtus strigosa v. glabrescentia, denticulato-serrulata $\nabla$. serrata.

Folia basi cuneata; petioli $\mathbf{1 . 5}-\mathbf{3} \mathrm{cm}$. longi, rarius longiores, serraturis porrectis . . . . . . . . 20. H. strigosa.

Folia basi rotundata $\nabla$. subcordata, rarius late cuneata, petioli 4-20 cm. longi.

Folia denticulato-serrulata et saepe duplicato-denticulata serraturis setoso-mucronulatis, ad $25 \mathrm{~cm}$. longa, subtus dense strigosa, subchartacea . . . . . . . . 21. H. Rosthornii.

Folia serrata, serraturis late triangularibus, breviter acuminatis, 6$18 \mathrm{~cm}$. longa, subtus strigosa $\nabla$. glabrescentia, membranacea.

22. H. longipes.

Folia integra; flores steriles sepalis plerumque 2; frutices scandentes.

Folia ovata v. elliptica, basi rotundata . . . 23. H. integrifolia. Folia oblongo-elliptica, basi attenuata . . . . 24. H. integra.

** Semina undique ala angusta cincta, compressa, laevia; petala apice coherentia calyptratim decidua; frutices radicibus scandentes ramulis medulla brunnea angustiore evanescente ideoque subfistulosis.

Sect. II. CALYPTRANTHE.

Stamina 10; folia ovata $\nabla$. elliptica basi cuneata v. rotundata, denticulatoserrata. ............. 25. H. anomala. Stamina 15; folia late ovata, basi truncata v. subcordata, argute serrata.

26. H. petiolaris. . 


\section{ENUMERATION OF THE SPECIES.}

Sect. I. EUHydrangea Maximowicz in Mém. Acad. Sci. St. Pétersbourg, sér. 7, X. No. XVI. 7 (1867).

Subsect. 1. PETALANTHAE Maximowicz, $l$. $c$.

This subsection is taken here in a wider sense than in its original conception and includes all the species with a wingless or nearly wingless seed. The ovary is partly superior with 3-4 styles and the cymes are usually flat; the petals are spreading or reflexed and usually persistent during anthesis. Petioles 1-3, rarely $5 \mathrm{~cm}$. long.

1. Hydrangea chinensis Maximowicz, l. c. (1867) - Hemsley in Jour. Linn. Soc. XXIII. 273 (1887).

Fokien: April-June 1905, S. T. Dinn (No.2664). Formo sa: Tamsuy, 1864, R. Oldham; Bankinsing, A. Henry (Nos. 98, 590, 1716).

2. Hydrangea umbellata Rehder. See p. 25.

3. Hydrangea Davidii Franch. See p. 25.

4. Hydrangea yunnanensis Rehder, n. sp.

Frutex metralis v. ultra ramulis hornotinis dense strigilloso-villosulis, annotinis flavescentibus. Folia membranacea, oblonga v. oblongo-lanceolata, acuminata, basi cuneata, dentata $v$. denticulata basi excepta, 7-12 $\mathrm{cm}$. longa et $2.5-4 \mathrm{~cm}$. lata, supra luteo-viridia, sparse setulosa v. glabrescentia, ad costam dense strigilloso-villosa, subtus pallida, costa venisque setulosis exceptis glabrescentia v. interdum parce setulosa, utrinsecus 10-14-costata; petioli crispulo-villosi, circa $1 \mathrm{~cm}$. longi. Cyma fere plana v. convexa, radiis 5-7 oppositis remotis composita, strigiloso-villosa; flores steriles $3-4 \mathrm{~cm}$. diam., sepalis $3-4$, late ovatis albis plerumque paucidentatis $v$. denticulatis; flores fertiles cyanei pedicellis plerumque receptaculo brevioribus; calycis dentes triangulari-ovati; petala obovato-oblonga, staminibus longioribus subaequilonga, circa $3 \mathrm{~mm}$. longa; styli 3 . Capsula ovoidea stylis persistentibus inclusis 4-5 mm. longa, pars libera fere duplo longior quam tubus calycis; styli apice valde recurvati stigmatibus fere circulum formantes; semina late elliptica, exalata.

Yunnan: Mengtze, mountain forests to the north, alt. 2100 m., A. Henry (Nos. 10236, $10236 \mathrm{~B})$.

Closely related to $H$. Davidii Franch. which is easily distinguished by its linearlanceolate sepals, lanceolate petals, longer and slenderer pedicels, suborbicular capsules and straight styles only slightly curved at the apex.

5. Hydrangea Moellendorfii Hance in Jour. Bot. XII. 177 (1874).

Kiangsi: near Kiukiang (ex Hance).

I have seen no specimen of this species, but as Hance states that it is closely related to $H$. hirta I assume that the inflorescence is peduncled and leafless as in that species.

6. Hydrangea opuloides K. Koch, Dendr. I. 353 (1869).

Hydrangea japonica Siebold in Nov. Act. Acad. Leop.-Carol. XIV. pt. ii. 689 (Syn. Hydrang.) (1829).

Hydrangea opuloides, var. Hortensia Dippel, Handb. Laubholzk. III. 322 (1893). Hortensia opuloides Lamarck, Encycl. III. 136 (1789). - Jacquin, Fragm. Bot. 7 , t. 3 (1800).

Hortensia japonica Gmelin, Syst. II. 722 (1791). - Zorn, A uswahl Schön. Gevo. III. 58, t. 149 (1796).

Hydrangea hortensis Smith, Icon. Pict. t. 12 (1792). - Sims in Bot. Mag. XIII. t. 438 (1799). - Savi, Fl. Ital. III. 65, t. 110 (1824). 
Hortensia mutabilis Schneevoogt, Icon. Pl. Rar. 36 t. (1793).

Hortensia speciosa Targioni-Tozzetti in Ann. Imp. Mus. Firenze, I. Obs. Bot. 36 , t. 2 (1808).

Hydrangea Hortensia Siebold in Nov. Act. Acad. Leop.-Carol. XIV. pt. ii, 688 (Syn. Hydrang.) (1829).

Hydrangea japonica, $\gamma$ Hortensia Regel in Gartenfl. XV. 290 (1866).

Hydrangea Hortensia, \& Hortensia Maximowicz in Mém. Acad. Sci. St. Pétersbourg, sér. 7, X. No. XVI. 14 (1867).

Hydrangea hortensis, var. Hortensia Rehder in Bailey Cycl. Am. Hort. II. 785 (1900).

Hupeh: A. Henry (No. 7385 with all the flowers sterile). Szech'uan: Nanch'uan, August 24, 1891, A. von Rosthorn (No. 602 with all the flowers sterile); Shi-tsu-kou, July 27, 1891, A. von Rosthorn (No. 75, without flowers).

No. 7385 of Henry and No. 602 of Rosthorn represent the form with all the flowers sterile, like the well-known garden forms. As long as the form with fertile flowers has not been collected in a wild state in western China, its spontaneous occurrence must remain doubtful. So far no European collector has ever seen and collected it wild in these regions and the notes of the native collector who gathered the plants for A. von Rosthorn must be taken with some caution.

Subsect. 2. HETEROMALLAE Rehder, n. subsect.

Piptopetalae Maximowicz in Mém. Acad. Sci. St. Pétersbourg, sér. 7, X. No. XVI. 8 (in part) (1867).

This subsection is chiefly characterized by the partly superior ovary with 3-4 styles and by the seeds with a wing on each end. The inflorescence is strongly convex with remote ramifications and sometimes paniculiform; the fertile flowers are white in the Chinese species and the petals drop before the opening of the anthers. The petioles do not exceed $5 \mathrm{~cm}$. in length.

7. Hydrangea paniculata Siebold. See p. 25.

8. Hydrangea hypoglauca Rehder. See p. 26.

9. Hydrangea xanthoneura Diels. See p. 26.

10. Hydrangea pubinervis Rehder. See p. 27.

11. Hydrangea Bretschneideri Dippel, Handb. Laubholzk. III. 320 (1893). Rehder in Mitt. Deutsch. Dendr. Ges. XII. 121 (1903). - Schneider, Ill. Handb. Laubholzk. I. 390, fig. 250 h-l, 251 a-b (1905).

Hydrangea pubescens? Maximowicz in Mém. Acad. Sci. St. Pétersbourg, IX. 472 (Ind. Fl. Pekin.) (nom. nudum, not Decaisne) (1859). - Koehne, Deutsch. Dendr. 189 (1893).

Hydrangea vestita, var. pubescens Maximowicz in Mém. Acad. Sci. St. Pétersbourg, X. No. XVI. 10 (excl. synon. Decaisne) (1867). - Sargent in Gard. and For. III. 17, fig. 3 (1890).

Hydrangea aspera Zabel in Gartenfl. XXXVIII. 461 (not Don) (1889).

Hydrangea pekinensis Hort., synon. ex Dippel, $l$. c.

Hydrangea vestita Hort., synon. ex Dippel, l. c.

Chili: near Pekin (ex Maximowicz). In cultivation; originally raised from seed collected by Dr. Bretschneider near Pekin and sent to the Arnold Arboretum (Koehne, Herb. Dendr. No. 4070).

I do not see any reason to doubt the identity of Bretschneider's plant with the $H$. vestita, var. pubescens Maximowicz; the description of the latter agrees exactly with the form cultivated in the Arnold Arboretum which shows a much denser pubescence than Koehne's No. 4070. The true $H$. heteromalla Don ( $H$. vestita Wallich) is easily distinguished by the dense white tomentum of the under side of the leaves and their fimbriately denticulate margin. 
Hydrangea Bretschneideri, var. lancifolia Rehder. See p. 28.

Hydrangea Bretschneideri, var. Giraldii Rehder, n. var.

Hydrangea Giraldii Diels in Bot. Jahrb. XXIX. 373 (1900).

I am not able to separate $H$. Giraldii specifically from $H$. Bretschneideri; it seems to differ only in narrower leaves gradually narrowed into the petiole and in the paler color of the bark. In the shape of the leaves it resembles $H$. xanthoneura, var. Wilsonii Rehd. which is easily distinguished by the leaves being glabrous or nearly so beneath.

Northern Shensi: T'ai-pa-shan, December 1893, G. Giraldi (No. 1169 ! No. 1172 ex Diels); Huan-tou-shan, Ki-shan, G. Giraldi (No. 1167, 1171 ex Diels); Tue-lian-pin, G. Giraldi (No. 1168).

12. Hydrangea mandarinorum Diels in Bot. Jahrb. XXIX. 372 (1900).

Szech'uan: Nanch'uan, A. von Rosthorn (No: 1932 in Herb. Christiania).

Diels places this species in the section Petalanthae, but it does not differ in the structure of its flowers from $H$. heteromalla Don and its allies.

Subsect. 3. ASPERAE Rehder, n. subsect.

Piptopetalae Maximowicz in Mém. Acad. Sci.St. Pétersbourg, X. No. XVI. 8 (in part) (1867).

This subsection is chiefly characterized by the inferior ovary developing into a hemispheric or turbinate capsule truncate at the apex. The seeds have a wing on each end; the styles are usually 2 ; the petals fall off before the stamens are fully developed, sometimes as a whole by cohering at the apex. The petioles sometimes attain $20 \mathrm{~cm}$. in length.

13. Hydrangea Sargentiana Rehder. See p. 29.

14. Hydrangea longifolia Hayata in Jour. Coll. Sci. Tokyo, XXV. 91 (Fl. Mont. Formos.) (1908).

Formosa:Taitou, Torokusha, T.Kawakami \& G. Nakahara (No.690, ex Hayata).

15. Hydrangea Kawakamii Hayata, l. c. 90, t. 8 (1908).

Formosa: Mt. Morrison, alt. 2300 m., T. Kawakami \& U. Mori (No. 1875, ex Hayata).

16. Hydrangea villosa Rehder. See p. 29.

Hydrangea villosa, var. strigosior Rehder, n. comb.

Hydrangea aspera, var. strigosior Diels in Bot. Jahrb. XXIX. 375 (1900).

Szech'uan: Tsaku-lao, Wei-kuan, August 20, 1891, A. von Rosthorn (No. 2546). Hupeh: A. Henry (No. 2473); August 1901, E. H. Wilson (Veitch Exped. No. $1473^{\mathrm{a}}$, with sterile flowers).

Differs from the type by its less villous tomentum. Branchlets usually only appressed strigose with fulvous hairs at the nodes; petioles hirsute with fulvous hairs interspersed; leaves hirsute-villose beneath, the hairs on the veins scarcely longer and not fulvous.

17. Hydrangea fulvescens Rehder, n. sp.

Frutex circa $1 \mathrm{~m}$. altus ramulis junioribus parce strigosis pilis patentibus rufescentibus intermixtis, vetustioribus griseo-brunneis peridermate solubili. Folia membranacea, ovata $v$. ovato-oblonga, acuminata, basi rotundata v. subcordata, irregulariter serrata serraturis triangularibus acuminatis plerumque curvatis, 9-13 cm. longa et $4.5-8.5 \mathrm{~cm}$. lata, supra flavo-viridia, strigosa, in costa venisque densius strigosa, subtus pallidiora dense hirtello-strigosa in costa media venisque pilis longis hirtis fulvis praedita, utrinsecus 7-9-costata; petioli graciles, pilis hirtis et interdum strigosis obsiti, 3-9 cm. longi. Cyma plerumque 5-radiata, laxa, strigosa pilis patentibus fulvis interspersis; flores radiantes albi sepalis 4 
orbiculato-obovatis integris leviter emarginatis; flores fertiles coerulescentes; calycis dentes triangulares, vix tubum dimidium aequantes; petala oblongo-ovata, circa $2 \mathrm{~mm}$. longa; stamina longiora 6-7 $\mathrm{mm}$. longa, brevioribus duplo longiora; styli 2 ; ovarium inferum. Capsulae maturae desiderantur.

Szech'uan: Wushan, July 1900, E. H. Wilson (Veitch Exped. No. 1393, type). Hupeh: A. Henry (No. 5949).

Closely allied to $H$. longipes Franchet, which differs in its tomentum consisting only of strigose hairs and in its white fertile flowers.

18. Hydrangea glabripes Rehder. See p. 30 .

19. Hydrangea aspera D. Don, Prodr. Fl. Nepal. 211 (1824).-Clarke in Hooker f., Fl. Brit. Ind. II. 404 (1878).

Hydrangea vestita Wallich, Tent. Fl. Nepal. t. 49, fig. 5-8 (in part, excl. fig. 1-4 and flowering branch) (1826).

Hydrangea vestita Wallich, var. fimbriata Wallich, Cat. No. 440 B. (nomen nudum) (1828). - De Candolle, Prodr. IV. 14 (1830).

Yunnan: Mengtze, alt. 1800 m., A. Henry (No. 9208).

This is the only Chinese specimen I have seen which I can refer to the typical $H$. aspera. The capsules, however, are smaller than in the type and have partly 2 and partly 3 styles. The variety described by Pampanini as $H$. aspera, var. cordata (in Nuov. Giorn. Bot. Ital. n. ser. XVII. 283, [1910]), based on Nos. 835, 835 C. Silvestri from Ou-tan-shan, western Hupeh, probably does not belong to $H$. aspera nor to $H$. strigosa, but as I have seen no specimens and the description given is too brief, I am not able to place it.

Hydrangea aspera, var. velutina Rehder. See p. 30.

Hydrangea aspera, var. scabra Rehder. See p. 31.

20. Hydrangea strigosa Rehder. See p. 31.

21. Hydrangea Rosthornii Diels. See p. 33.

22. Hydrangea longipes Franchet. See p. 33.

Hydrangea longipes, var. lanceolata Hemsley in Jour. Linn. Soc. XXIII. 274 (1887).

Hupeh: Ichang, A. Henry (No. 1786, type). Szech'uan: Changyang, June 1900, E. H. Wilson (Veitch Exped. No. 1150).

23. Hydrangea integrifolia Hayata in Jour. Coll. Sci. Tokyo, XXII. 131 (Enum. Pl. Formos.) (1906).

Formosa: on rocks, Taitou, U. Faurie (No. 105 ex Hayata).

24. Hydrangea integra Hayata in Jour. Coll. Sci. Tokyo, XXV. 90, t. 7 (Fl. Mont. Formos.) (1908).

Formos a: Mt. Morrison, T. Kawikami \& U. Mori (No. 1723 ex Hayata).

Sect. II. CALYPTRANTHE Maximowicz in Mém. Acad. Sci. St. Pétersbourg, X. No. XVI. 16 (1867).

This section is well characterized by the compressed seeds having a narrow wing all around, by the climbing habit, the branchlets affixing themselves by means of rootlets, by the brown partly evanescent pith of the one year old branchlets and by the petals being thrown off as a whole by the extending stamens. The falling off as a whole of the petals occurs also occasionally in the section Asperae, which hardly differs from Calyptranthe in the structure of the flowers and also contains a few climbing species.

25. Hydrangea anomala D. Don. See p. 34 . 
26. Hydrangea petiolaris Siebold \& Zuccarini, Fl. Jap. I. 106, t. 54 (1835). Schneider, Ill. Handb. Laubholzk. I. 393, fig. 252 a-i (1905).

Hydrangea cordifolia Siebold \& Zuccarini, l. c. 113, t. 59, fig. 2 (1835).

Hydrangea bracteata Siebold \& Zuccarini, l. c. 176, t. 92 (1835).

Hydrangea scandens Maximowicz in Mém. Acad. Sci. St. Pétersbourg, sér. 7, X. No. XVI. 16 (1867).

Hydrangea tiliaefolia Léveillé in Fedde, Rep. Nov. Sp. VIII. 282 (1910).

Korea: Quelpaert, U. Faurie (Nos. 358, 1654), T. Taquet (Nos. 809, 2884).

Faurie's Nos. 358 and 1654 and Taquet's No. 809 are the type numbers of Léveille's $H$. tiliaefolia, which is undistinguishable from $H$. petiolaris.

The following three Chinese species from Kwei-chau recently described by Léveille I am not able to place, as I have seen no specimens, and the descriptions are too incomplete for recognition.

Hydrangea Maximowiczii Léveillé in Bull. Acad. Intern. Geog. Bot. XII. 114 (1903).

Hydrangea Kamienskii Léveillé, l. c. 115.

Hydrangea Arbostiana Léveillé, l. c. 115.

The first resembles in its short stamens $H$. Lobbii Maximowicz, but differs in its tomentose pubescence, the second is closely related apparently to $H$. heteromalla Don, but has lanceolate petals, while the third may belong either to the Petalanthae or to the Heteromallae, the description of the seeds as "imperfecte oblonga" may mean that they are winged or wingless.

\section{SCHIZOPHRAGMA SiEb. \& ZUCC.}

Determined by AlFred ReHder.

Schizophragma integrifolium Oliver in Hooker's Icon. XX. t. 1934 (1890).

Schizophragma hydrangeoides, var. integrifolium Franchet in Nouv. Arch. Mus.

Paris, sér. 2, VIII. 266 (1885); Pl. David. II. 44 (1888.)

Schizophragma Fauriei Hayata in Jour. Coll. Sci. Tokyo, XXII. 131. (Enum. Pl. Formos.) (1906.)

Western Szech'uan: Mupin (type locality), rocky places, cliffs, alt. 1600-1800 m., July and October 1908 (No. Io68), Nov., 1908 (No. I25I, fruiting specimen), alt. 1800-2300 m., October 1910 (No. 4339); Wa-shan, rocky places, alt. 1200-1800 m., August, 1908 (No. Ir94); Wa-ssu country, Wên-chuan Hsien, rocky places, alt. 12002100 m., Aug., 1908 (No. 2568); without locality, cliffs, alt. 1400 m., June 1903 (Veitch Exped. No. 3562). Formosa: Mt. Taitou, U. Faurie (No. 104, ex Hayata).

A very variable species; the typical form which is represented by the plant of western Szech'uan is characterized by large and broad leaves, generally ovate, and subcordate at the base, of firm, sometimes subcoriaceous texture, entire or only sparingly denticulate near the apex, glabrous and green beneath and more or less reticulate. All the specimens quoted above belong to this form except Faurie's No. 104 from Formosa, which I have not seen; it may represent a form differenc 
from any of the following four varieties. No. 4339 has the petioles and the leaves slightly pubescent beneath, and may be considered a transition to the following variety.

Schizophragma integrifolium, var. molle Rehder, n. var.

Differt a typo foliis subtus dense et molliter pubescentibus petiolis 1.5-6 cm. longis, villosis cyma laxe pubescente. Sepala florum sterilium ovata, basi rotundata, acutiuscula, $5-8 \mathrm{~cm}$. longa, 3-5 cm. lata.

Western Szech'uan: Wa-shan, cliffs, alt. 1600-1800 m., July 1908 (No. I25I, in part, flowering specimen only); Mupin, cliffs, alt. 1800 m., July 1908 (No. I25I, in part, flowering specimen).

Strikingly different from the type in the dense and soft tomentum of the under side of the leaves, which otherwise in texture, size and shape resemble closely those of the typical form.

Schizophragma integrifolium, var. denticulatum Rehder, n. var.

Differt a typo foliis membranaceis vel fere chartaceis, ovato-oblongis vel ovatis, basi rotundatis, acuminatis, minuto-dentatis vel denticulatis basi excepta, $10-15 \mathrm{~cm}$. longis et $5.5-9 \mathrm{~cm}$. latis, concoloribus, subtus ad venas laxe et ad venulas sparse pilosis, petiolis glabrescentibus, 3-7 cm. longis. Sepala florum sterilium ovato-oblonga basi late cuneata, 4-6 $(-8) \mathrm{cm}$. longa et $2-3(-4) \mathrm{cm}$. lata.

Western Hupeh: Chang-lo Hsien, rocky places, alt. $1200 \mathrm{~m}$., June 1907 (No. 2563); Hsing-shan Hsien, cliffs, rocky places, alt. 12001800 m., November, July and August 1907 (Nos. 572, 2566, 2567); Changyang Hsien, rocks, sunny places, alt. 900-1200 m., April and July 1907 (No. 2564); South Wushan, cliffs, alt. 1200 m., July and September 1907 (No. 2565); Fang Hsien, cliffs, alt. 1800-2100 m., October 1910 (No. 4462); without locality, June 1900 (Veitch Exped. No. 1065), July 1900 (Veitch Exped. No. 1320); Patung, July 1901 (Veitch Exped. No. 1158). Kiangsi: Kuling, common among rocks, alt. 900 m., August 1907 (No. I727).

Differs from the type in its thinner, dentate or denticulate leaves, slightly pubescent on the veins beneath or sometimes glabrous. In the No. 2563 which I consider the type of this variety and also in No. 4462 the leaves are sinuately dentate, while in all the others they are merely denticulate.

Schizophragma integrifolium, var. glaucescens Rehder, $\mathrm{n}$. var.

A typo recedit foliis chartaceis, ovatis v. oblongo-ovatis, basi rotundatis v. late cuneatis, integris, $8-12 \mathrm{~cm}$. longis et $3.5-7 \mathrm{~cm}$. latis, supra laete viridibus, subtus glaucescentibus glabris sed in axillis barbatis; sepalis florum sterilium oblongis acutiusculis, basi cuneatis, $3.5-5 \mathrm{~cm}$. longis et $1-2 \mathrm{~cm}$. latis. 
Western Szech'uan: Wa-shan, cliffs, alt. 1200-1800 m., July 1908 (No. 2569).

Differs from the type in its thinner and smaller leaves glaucescent beneath, sometimes nearly oblong in outline and in its smaller sterile flowers.

To complete the enumeration of the Chinese Schizophragmas, the following varieties and species which are not represented in the recent Wilson collection are appended here.

Schizophragma integrifolium, var. minus Rehder, n. var.

A typo recedit foliis membranaceis, ovatis, v. subcordatis, integris $\mathrm{v}$. fere integris, minoribus, tantum 8-10 cm. longis et 5.5-6.5 cm. latis, supra flavo-viridibus, subtus pallidioribus, sepalis florum sterilium oblongo-ovatis, acutiusculis, basi cuneatis, 3-3.5 cm. longis et 1-1.5 latis.

Hupeh: A. Henry (No. 5965, type); South Washan, wet place, June 1900, E. H. Wilson (Veitch Exped. No. 1065).

Differs from the type in its smaller and thinner leaves and much smaller sterile flowers.

Schizophragma hypoglaucum Rehder, n. sp.

Frutex radicibus scandens. Folia chartacea, oblongo-ovata, manifeste acuminata, basi rotundata $v$. late cuneata, integerrima, 8-15 cm. longa et $3.5-6.5$ lata, supra obscure viridia glabra, subtus glauca (sub microscopio dense papillosa), glabra axillis barbatis exceptis. Cyma fere glabra; tubus calycis glaber; sepala florum sterilium oblonga vel anguste oblonga, basi cuneata, apice obtusa, subtus glaucescentia et papillosa, 3-5 cm. longa et 7-17 $\mathrm{mm}$. lata.

Szech'uan: Mt. Omei, July 1904, E. H. Wilson (Veitch Exped. No. 4885).

In the shape and smoothness of the leaves it resembles much S. integrifolium, var. glaucescens Rehder which has the leaves glaucescent beneath, but the species is easily distinguished by the intensely glaucous color of the under side of the leaves and particularly by the papillae which are entirely wanting in that variety, also by the dark green upper side, the glabrous calyx-tube and the obtuse sepals of the sterile flowers. It is so strikingly different from typical $S$. integrifolium that it is hardly advisable, though the variety glaucescens seems to represent a connecting link, to consider it a variety of that species, particularly as the papillosity of the under side of the leaves affords a good morphological character for separation.

Schizophragma hydrangeoides Siebold \& Zuccarini, Fl. Jap., I. 59, t. 26. (1835). - Schneider, Ill. Handb. Laubholzk I. 393, fig. 252 a-i (1905).

Hydrangea Taquetii Léveille, in Fedde, Rep. Nov. Sp. VIII. 282 (1910).

Korea: Quelpaert, T. Taquet (Nos. 807, 808, 2885).

So far as I know S. hydrangeoides has never been reported from Korea before. Taquet's No. 807 and 808 represent the type of Hydrangea Taquetii Léveillé.

\section{'DICHROA Lour.}

\section{Determined by Alfred ReHder.}

Dichroa febrifuga Loureiro, Fl. Cochin. 301 (1790). - Hemsley in Jour. Linn. Soc. XXIII. 275 (1887).

Western Hupeh: Ichang, ravines, alt. 1-500 m., June 1907 (No. 
2956). Western Szech'u an: Chang-yang, June 1901 (Veitch Exped. No. 1174); Mt. Omei, June 1904 (Veitch Exped. No. 4890). Fokien, $\mathrm{K} w a n g t u n g$ and Hong Kong (ex Hemsley).

\section{ITEA L.}

Determined by Alfred ReHder.

Itea ilicifolia Oliver in Hooker's Icon. XVI. t. 1538 (1886).

Western Hupeh: Ichang, abundant, alt. 300-900 m., June, September and November 1907 (No. 325, in part); April 1900 (Veitch Exped. No. 144). Western Szech'uan: near Wa-shan, cliffs, alt. 900 m., July 1908 (No. 325, in part).

\section{RIBES L.}

Determined by ED. JANCZEwskr.

Ribes himalayense Decaisne, a glandulosum Janczewski in Bull. Acad. Cracovie Sci. Nat. 1910, 69.

Western Szech'uan: southeast of Tachien-lu, rocky places, alt. 2100-2550 m., June 1908 (No. 999); Mupin, woodland, 1800-2400 m., July 1908 (Nos. 799, I800).

Ribes himalayense, $\gamma$ urceolatum Janczewski in Bull. Acad. Cracovie Sci. Nat. 1910, 69.

Western Hupeh: Fang Hsien, thickets, alt. 2250 m., September 1907 (No. 3I7).

Ribes Meyeri Maximowicz, a tanguticum Janczewski, Monogr. Groseill. ${ }^{1} 299$ (1907).

Western Szech'uan: Pan-lan-shan, west of Kuan Hsien, thickets, alt. 1200-1800 m., August 1908 (No. 803); Mupin, thickets, alt. 1800-2100 m., August 1908 (No. 896).

Ribes moupinense Franchet, $\beta$ tripartitum (Batalin) Janczewski, Monogr. Groseill. 300 (1907).

Western Hupeh: Hsing-shan Hsien, woods, alt. 1500 m., June 1907 (No. I802), thickets, alt. 1200 m., May 26, 1907 (No. r8o3).

Ribes moupinense, $\gamma$ laxiflorum Janczewski in Bull. Acad. Cracovie Sci. Nat. 1910, 70.

Western Szech'uan: Wa-shan, thickets, alt. 1800 m., July 1908 (No. 822); Ta Hsing-ling, Ching Chi Hsien, among rocks, alt. 1800-

1 Monographie des Groseilliers, originally published in Mém. Sci. Phys. Genève, XXXV. 
2100 m., May 1908 (No. I797); Chin Ting-shan, thickets, alt. 2400 m., May 23, 1908 (No. I8or).

Ribes longeracemosum Franchet, $a$ Davidii Janczewski in Bull.Acad. Cracovie Sci. Nat. 1910, 71.

Western Szech'uan: Ta Hsiang-ling, Ching Chi Hsien, alt. 2100 m., May 1908 (No. 898); Mupin, woodlands, alt. 1800-2400 m., June 1908 (No. 898, in part); Ching Chi Hsien, thickets, alt. 2700-3000 m., September 15, 1908 (No. 929); Wa-shan, thickets, alt. 2100-2400 m., June 1908 (No. I798).

Ribes longeracemosum, $\beta$ Wilsonii Janczewski in Bull. Acad. Cracovie Sci. Nat. 1910, 71.

Western Hupeh : Fang Hsien, woodlands and thickets, alt. 15002400 m., May 27, August and September 1907 (No. 280).

Ribes alpestre Decaisne, a commune Janczewski in Bull. Acad. Cracovie Sci. Nat. 1910, 72.

Western Hupeh: Fang Hsien, thickets, alt. 2100-2550 m., May, July and September 1907 (No. 277).

Ribes alpestre, $\beta$ giganteum Janczewski in Bull. Acad. Cracovie Sci. Nat. 1910, 72.

Western Szech'uan: common hedge-plant around Tachien-lu, alt. 2400-3350 m., July 9 and 26, 1908 (No. 836).

Ribes pulchellum Turczaninow in Bull. Soc. Nat. Moscou, V. 191 (1832).

Western Szech'uan: Wa-ssu country, Wên-chuan Hsien, among rocks, alt. 2400 m., November 1908 (No. 1246); near Mongkong Ting, side of streams, alt. 2700 m., June 27, 1908 (No. 1789).

Ribes Vilmorinii Janczewski in Bull. Acad. Cracovie Sci. Nat., 1906, 290.

Western Szech'uan: Ta-p'ao-shan, Ching-chi Hsien, thickets, alt. 2700 m., September 15, 1908 (No. 913).

Ribes humile Janczewski in Bull. Acad. Cracovie Sci. Nat., 1910, 73.

Western Szech'uan : Pan-lan-shan, west of Kuan Hsien, on rocks, alt. 2100 m., June 1908 (No. I788).

Ribes tenue Janczewski in Bull. Acad. Cracovie Sci. Nat., 1906, p. 290.

Western Szech'uan: Wa-shan, rocky places, alt. 1800 m., July 
1908 (No. 823); Ching Ting-shan, thickets, alt. 1800 m., May 25, 1900 (No. I794); Nin-tou-shan, west of Kuan Hsien, thickets, alt. 1800 m., June 20, 1908 (No. I795). Western Hu peh: Chang-lo Hsien, woodlands, alt. 1200 m., May 1907 (No. 38); Tatung Hsien, rocky places, alt. 1500 m., July 1907 (No. 9o).

Ribes glaciale Wallich in Roxburgh, Fl. Ind. II. 513 (1824).

Western Hupeh: Fang Hsien, woods, alt. 2250 m., May 18 and September 1907 (No. I80, forma sepalis angustis); Patung Hsien, cliffs, alt. 1200 m., April 1907 (No. I790); Hsing-shan Hsien, thickets, common, alt. 1580 m., May 26, 1907 (No. I79I, forma sepalis latioribus).

Ribes glaciale, $\beta$ glandulosum Janczewski in Bull. Acad. Cracovie Sci. Nat., 1910, 74.

Western Hupeh: Fang Hsien, side of streams in thickets, alt. 1800 m., May 15, 1907 (Nos. I792, I793).

Ribes luridum Hooker f. \& Thomson in Jour. Linn. Soc. II. 87 (1858).

Western Hupeh : Chang-lo Hsien, thickets and cliffs, alt. $1200 \mathrm{~m}$., May and July 1907 (No. Ioo).

Ribes acuminatum Wallich in Roxburgh, Fl. Ind. II. 514 (1824).

Western Szech'uan: Chin-ting-shan, alt. 1800-2400 m. (No. I796).

Ribes Maximowiczii Batalin in Act. Hort. Petrop. XI. 487 (1890).

Western Szech'uan: Mupin, thickets, alt. 1800 m., September 1908 (No. 870); Chin-ting-shan, thickets, alt. 1500-2250 m., May 23, 1908 (No. 958); Wa-shan, thickets, 1800-2250 m., August 1908 (No. 958, in part).

Ribes Franchetii Janczewski in Bull. Acad. Cracovie Sci. Nat., 1909, 64 , figs. 3,4 .

Western Hupeh: Fang Hsien, thickets, alt. 1500-2100 m., May 19, 28 and August 1907 (No. 73 in part), September 1907 (No. I9I); Hsing-shan Hsien, cliffs and woods, alt. 2250 m., May 3, 1907 (No. 73, in part).

Ribes laurifolium Janczewski in Bull. Acad. Cracovie Sci. Nat., 1910, 79, fig. 6 .

Western Szech'uan: Wa-shan, rocks, rare, alt. 2300 m., September 1908 (No. 817). 


\title{
ROSACEAE.
}

\author{
SORBARIA A. Br.
}

Determined by AlFred ReHder.

Sorbaria arborea Schneider, Ill. Handb. Laubholzk. I. 490, fig. 297 (1905).

Western Hupeh: Chang-lo Hsien, thickets, alt. 1500-2100 m., July and October 1907 (No. 499 $)$; Chang-yang Hsien, thickets, alt. 1500-1800 m., July 1907 (No. 274r); Fang Hsien, thickets, alt. 15002100 m., July 1907 (No. 2742); Hsing-shan Hsien, woodlands, alt. 1500-1800 m., July 1907 (No. 2743); Patung Hsien, thickets, alt. 1500-2400 m., July 1907 (No. 2743ª). Western Szech'uan: Mupin, woodlands, alt. 1500-2400 m., November 1908 (No. I235, in part); Wa-shan, thickets, alt. 1600-2200 m., July 1908 (No. 2745).

This variable species is most nearly related to $S$. Lindleyana Maximowicz from which it differs in its longer stamens, two or three times as long as the petals, in the shorter calyx-tube and in the leaflets being cuneate at the base and covered beneath with a fasciculate floccose tomentum or glabrous in one variety.

Sorbaria arborea, var. subtomentosa Rehder, n. var.

A typo recedit foliis subtus tomento fasciculato densiore usque ad maturitatem persistente vestitis, argute minuteque biserrulatis, venis magis congestis circa $2 \mathrm{~mm}$. tantum distantibus, inflorescentia dense floccosa, densiore, ramis adscendentibus, floribus majoribus, petalis $3 \mathrm{~mm}$. longis, carpellis pubescentibus vel glabris.

Western Szech'uan: Wa-ssu country, Wên-chuan Hsien, woodlands, alt. 1800-3100 m., November 1908 (No. r235, fruiting specimen, type); Ta Hsing-ling, Ching-chi Hsien, thickets, alt. 1600-2200 m., August 1908 (No. 2744, flowers); Pan-lan-shan, west of Kuan Hsien, woodlands, alt. 2100-2400 m., September 1910 (No. 4474).

Differs from the type in its denser persistent tomentum of the under side of the leaves, their more closely set veins, $2 \mathrm{~mm}$. apart, while in the type they are $3-4$ $\mathrm{mm}$. apart, and in the more densely tomentose inflorescence. In the type specimen the follicles are sparingly pubescent, while in the flowering specimen they are quite glabrous; therefore these two specimens may possibly represent two distinct forms, but in foliage they are exactly alike. 
Sorbaria arborea, var. glabrata Rehder, n. var.

A typo recedit foliis glabris subtus tantum in axillis barbatis $v$. interdum ad costam mediam minute puberulis, panicula glabra $\mathrm{v}$. tantum in parte inferiore tomento floccoso cito deciduo vestita.

Western Hupeh: Hsing-shan Hsien, thickets, alt. 1500-2100 m., July and October 1907 (No. 499). Eastern Szech'uan: South Wushan, A. Henry (No. 6245). Western Szech'uan: West of Kuan Hsien, thickets, alt. 2100-2700 m., August 1910 (No. 4475); Pan-lan-shan, west of Kuan Hsien, woodlands, alt. $2500 \mathrm{~m}$., September 1910 (No. 4476); around Sungpan, thickets, alt. 2400-2700 m., August 1910 (No. 4477); Mupin, woodlands, alt. 2400-2700 m., October 1910 (No. 4340).

Differs from the type chiefly in its glabrous foliage. The Hupeh plant, which I consider as representing the type of this variety, has the leaves generally oblonglanceolate to lanceolate, the inflorescence narrower with ascending branches and the stamens sometimes nearly three times as long as the petals, while the Szech'uan form has the leaflets generally oblong-ovate or oval-ovate, the inflorescence loose with spreading branches and the stamens less than twice as long as the petals. No. 4340 differs again in the more closely set veins of the leaflets, resembling in this respect the var. subtomentosa.

\section{RUBUS L.}

Determined by W. O. Focke.

\section{Subgen. DALIBARDA}

Rubus Fockeanus S. Kurz in Jour. As. Soc. Bengal, XLIV. pt. II. 206 (1875). - Focke in Bibl. Bot. LXXII. 16 (Spec. Rub.) (1910).

Rubus loropetalus Franchet, Pl. Delavay. 203 (1890).

Western Szech'uan: Tachien-lu, alpine regions, alt. 3300-3700 m., September 1908 (No. 1002).

Rubus loropetalus can not be distinguished with certainty in the herbarium from $R$. Fockeanus.

\section{Subgen. CYLACTIS}

Rubus simplex Focke in Hooker's Icon. X. t. 1948 (1854); in Bibl. Bot. LXXII. 28 (Spec. Rub.) (1910).

Western Hupeh: Fang Hsien, thickets, alt. 1800 m., September 1907 (No. 282). 
Rubus xanthocarpus Bureau and Franchet in Jour. de Bot. V. 46 (1891). - Focke in Bibl. Bot. LXXII. 29 (Spec. Rub.) (1910).

Western Szech'uan: Min Valley, Mao-chou, stony places, alt. 1200-2700 m., May and August 1908 (No. 806).

\section{Subgen. DALIBARDASTRUM}

Rubus tricolor Focke in Bibl. Bot. LXXII. 40 (Spec. Rub.) (1910).

Rubus polytrichus Franchet, Pl. Delavay. 203 (not Progel in 1882) (1890).

Western Szech'uan: Wa-shan, thickets, alt. 1800-2100 m., July and September 1908 (No. 828).

\section{Subgen. MALACHOBATUS}

Rubus hupehensis Oliver in Hooker's Icon. XIX. t. 1816 (1889).

Western Szech'uan: Patung Hsien, alt. 900-1200 m., June and July 1908 (No. 99).

I formerly was unable to find clear distinctions in the descriptions of $R$. Swinhoei Hance and $R$. hupehensis; therefore I combined the two species. Now I think, however, that there are constant characters by which the two plants can be distinguished. $R$. Swinhoei is evergreen, whereas $R$. hupehensis seems to have deciduous leaves.

Rubus Henryi Hemsley \& Kuntze in Jour. Linn. Soc. XXIII. 231 (1887). - Focke in Bibl. Bot. LXXII. 43 (Spec. Rub.) (1910).

Rubus bambusarum Focke in Hooker's Icon. XX. text to t. 1952 (1891).

Western Hupeh: north and south of Ichang, thickets, alt. 12001800 m., June and August 1907 (No. 48); Changyang Hsien, woods, alt. 1200-1800 m., June and July 1907 (No. 76).

Ternate and simply trifid leaves occur on the same branches of Mr. Wilson's specimens. This shows that $R$. bambusarum cannot be separated from $R$. Henryi.

Rubus Playfairianus Hemsley (in sched., nom. mutat.), apud Focke in Bibl. Bot. LXXII. 45 (Spec. Rub.) (1910).

Western Hupeh: common around Ichang, alt. 300-900 m., May and June 1907 (No.4). Western Szech'uan: Ta Hsing-ling, Ching Chi Hsien, thickets, alt. 300-900 m., May 1908 (No. 4²).

Rubus chroosepalus Focke in Hooker's Icon. XX. t. 1952 (1891); in Bibl. Bot. LXXII. 51 (Spec. Rub.) (1910). 
Western Hupeh: thickets around Ichang, alt. 300-900 m., July 1907 (No. 79).

Rubus fusco-rubens Focke, n. sp.

Affinis $R$. assamensi Focke sed foliis longius petiolatis cordatis facillime distinguendus. Rami et petioli tomentoso-pubescentes, aculeis falcatis mediocribus et parvis instructi. Petioli fere $4 \mathrm{~cm}$. longi; folia e basi lata cordata ovato-lanceolata, diam. $10.5 \mathrm{~cm}$., acuminata, fundo palmato-quinquenervia, praeterea utrinque fere 4-5-costulata, margine repando-sinuata, serrulata, supra in nervis solum pilosa, subtus cano-tomentosa; stipulae fugaces. Inflorescentia extraaxillaris, sicut in $R$. assamensi et $R$. chroosepalo; bracteae in lacinulas lineares fissae; pedicelli et calyces glanduliferi; sepala interne glabriuscula, cum disco fusco-rubentia; carpophorum fundo pilorum strictorum densissimorum cingulo circumdatum. Fructus nigri.

Western Hupeh: Changyang Hsien, alt. 900-1200 m., May and July 1907 (No. 3025).

Rubus Gentilianus Léveillé \& Vaniot in Bull. Acad. Intern. Geogr. Bot. XI. 99 (1902). - Focke in Bibl. Bot. LXXII. 53 (Spec. Rub.) (1910).

Western Szech'uan: Mupin, alt. 1200-1500 m., June and October 1908 (No. II27).

Rubus ichangensis Hemsley \& Kuntze in Jour. Linn. Soc. XXIII, 231 (1887). - Focke in Bibl. Bot. LXXII. 55 (Spec. Rub.) (1910).

Western Hupeh: Changyang Hsien, ravines, etc., alt. 600-1200 m., June and December 1907 (No. 663); Western Szech'uan: Mupin, thickets, alt. 1500-1800 m., October 1908 (No. ro52).

Rubus Parkeri Hance in Jour. Bot. XX. 260 (1882). - Focke in Bibl. Bot. LXXII. 67 (Spec. Rub.) (1910).

Rubus Parkeri, var. longisetosus Focke, n. var.

Western Hupeh: thickets around Ichang, alt. 300-900 m., April and June 1907 (No. 44).

Rubus Parkeri, var. brevisetosus Focke, n. var.

Western Hupeh: thickets around Ichang, alt. 300-900 m., May 1907 (No. 3023). 
Rubus Lambertianus Seringe in De Candolle, Prodr. II. 567 (1825). Focke in Bibl. Bot. LXXII. 70 (Spec. Rub.). (1910).

Western Hupeh: north and south of Ichang, thickets, alt. 300$1000 \mathrm{~m}$., September and October 1907 (No. 482).

Rubus clemens Focke in Bibl. Bot. LXXII. 105 (Spec. Rub.) (1910).

Western Szech'uan: Mupin, thickets, common, alt. 600-2100 m., July and September 1908 (No. 87I).

Rubus irenaeus Focke in Bot. Jahrb. XXIX. 394 (1901); in Bibl. Bot. LXXII. 144 (Spec. Rub.) (1910).

Western Hupeh: Changyang Hsien, woods, common, alt. 12002300 m., July and September 1907 (No. I4I); Chang-lo Hsien, side of streams alt. 900 m., July 1907 (No. 3022).

Unarmed or with a few minute inconspicuous prickles.

Rubus Buergeri Miquel in Ann. Mus. Lugd.-Bat. III. 36 (1867); Prol. Fl. Jap. 224 (1866-67).

Western Szech'uan: Hung Ya Hsien, woods, alt. 600 m., June 9, 1908 (No. 3014).

\section{Subgen. IDEOBATUS}

\section{Ser. CoRchoRIFoliI}

Rubus corchorifolius Linnaeus f., Suppl. Pl. Syst. Veget. 263 (1781).Focke in Bibl. Bot. LXXII. 131 (Spec. Rub.) (1911).

Western Hupeh: north and south of Ichang, thickets, alt. 3001200 m., June 2, 1907 (No. 15).

Rubus trianthus Focke in Bibl. Bot. LXXII. 140, fig. 59 (Spec. Rub.) (1911).

Western Hupeh: Chang-lo Hsien, alt. 1200-1500 m., July 1907 (No. 78).

\section{Ser. RosaEFolII}

Rubus Thunbergii Siebold \& Zuccarini in Abhand. Akad. Münch. IV. pt. II. 126 (1846). - Focke in Bibl. Bot. LXXII. 159, fig. 68 (Spec. Rub.) (1911). 
Rubus Thunbergii, var. glabellus Focke, n. var.

Differt a planta typica Japoniae statura robustiore et ramis foliisque parcius pilosis.

Western Hupeh: north and south of Ichang, roadsides, etc., alt. 300-900 m., May and July 1907 (No. 2); Hsing-shan Hsien, rocky places, alt. 300-900 m., May and June 1907 (No. 30r9).

Rubus Argyi Léveillé, R. talaikiaensis Léveillé and $R$. eustephanos Focke, which are closely allied to $R$. Thunbergii, are well distinguished from var. glabellus.

\section{Ser. Pungentes}

Rubus amabilis Focke in Bot. Jahrb. XXXVI. 53 (1905); in Bibl. Bot. LXXII. 163, fig. 70 (Spec. Rub.) (1911).

Western Szech'uan: Tachien-lu, alt. 2400-3000 m., June and August 1908 (No. 830).

Rubus pungens Cambessedes in Jacquemont, Voyage, IV. 48, t. 59 (1844). - Focke in Bibl. Bot. LXXII. 165 (Spec. Rub.) (1911).

Western Hupeh: Fang Hsien, thickets, alt. 1200-1800 m., May and August 1907 (No. 72); Hsing-shan Hsien, woodlands, alt. 12001800 m., May 16, 1907 (No. 72 in part); Changyang Hsien, thickets, alt. 600-1200 m., May 14, 1907 (No. 302r). Western Szech'uan: west of Kuan Hsien, alt. 1800-2100 m., May and June 1908 (No. 834).

Rubus pileatus Focke in Hooker's Icon. XX. text to t. 1952, p. 3 (1891); in Bibl. Bot. LXXII. 167 (Spec. Rub.) (1911).

Western Szech'u an: Was-su country, Wên-chuan Hsien, thickets, alt. 1800-2500 m., July and August 1908 (No. 813); Wa-shan, thickets, alt. 2100 m., September 1908 (No. 858 ); west of Kuan Hsien, clearings, alt. 1800-2500 m., June and September 1908 (No. 858 ); Panlan-shan, west of Kuan Hsien, alt. 2100-2700 m., June 1908 (No. 3018).

Rubus pileatus, var. foliolis subtus cano-tomentosis.

Western Szech'uan: Ching-Chi Hsien, uplands, alt. 2400-3000 m., September 15, 1908 (No. 858).

Rubus lasiostylus Focke in Hooker's Icon. XX. t. 1951 (1891); in Bibl. Bot. LXXII. 167 (Spec. Rub.) (1911). 
Western Hupeh: north and south of Ichang, thickets, alt. 12001800 m., September 1907 (No. r88).

Rubus lasiostylus, var. (v. subsp.) dizygos Focke, n. var.

Folia ramorum fertilium multa pinnato-quinata; stipulae bracteaeque angustiores videntur; flores rosei.

Western Hupeh: Fang Hsien, uplands, alt. 1600 m., July and September 1907 (No. 279).

Rubus eucalyptus Focke in Bibl. Bot. LXXII. 169 (Spec. Rub.) (1911).

Western Szech'uan: near Monkong Ting, thickets, alt. $1800 \mathrm{~m}$., June 19, 1908 (No. 3016); Chin Ting-shan, thickets, alt. 1500-2100 m., May 23, 1908 (No. 30I7).

This species belongs with $R$. pileatus, $R$. lasiostylus and $R$. trullissatus in a peculiar group characterized by white woolly fruits.

Rubus trullissatus, Focke in Bibl. Bot. LXXII. 169 (Spec. Rub.) (1911).

Western Hupeh: Hsing-shan Hsien, thickets, alt. 1200 m., June 1907 (No. 57).

Imperfectly known. The plant cannot be placed under another species.

Rubus biflorus Hamilton ex Smith in Rees, Cyclop. XXX. no. 9 (1819). - Focke in Bibl. Bot. LXXII. 166 (Spec. Rub.) (1911).

Rubus biflorus, var. quinqueflorus Focke, n. var.

Ramis fertilibus 3-8-floris.

Western Szech'uan: southeast of Tachien-lu, thickets, alt. 18002100 m., July 1908 (No. 832).

Rubus macilentus Cambessèdes in Jacquemont, Voyage, IV. 49, t. 60 (1844). - Focke in Bibl. Bot. LXXII. 166 (Spec. Rub.) (1911).

Western Szech'uan: Mupin, roadsides, alt. 1200-1800 m., May and August 1908 (No. 850).

Rubus lutescens Franchet, $\mathrm{Pl}$. Delavay. 206 (1889). - Focke in Bibl. Bot. LXXII. 162, fig. 69 (Spec. Rub.) (1911).

Western Szech'uan: Pan-lan-shan, west of Kuan Hsien, stony places, alt. 3300-3700 m. (No. 3026). 


\section{Ser. IDAEI}

Rubus thibetanus Franchet in Nouv. Arch. Mus. Paris, sér. 2, VIII. 221 (Pl. David. II. 39) (1885). - Focke in Bibl. Bot. LXXII. 179, fig. 74 (Spec. Rub.) (1911).

Rubus Veitchii Rolfe in Kew Bull. Misc. Inform. 1909, 258.

Western Szech'uan: Mao-chou, dry regions, alt. 1200-1800 m., May and August 1908. (No. 804).

A very curious plant and perhaps the type of a well marked section. It resembles the South African $R$. Ludwigii Ecklon \& Zeyher.

Rubus inopertus Focke in Bibl. Bot. LXXII. 182 (Spec. Rub.) (1911).

Rubus niveus, subsp. inopertus Focke in Bot. Jahrt. XXIX. 400 (1901).

Western Hupeh: north and south of Ichang, thickets, alt. 6001200 m., June and July 1907 (No. 97). Western Szech'uan: Washan, thickets, alt. 1500-2200 m., July and September 1908 (No. 946).

This Chinese plant seems to be rather constant, and looks very different from the tropical $R$. niveus Thunberg ( $R$. lasiocarpus Smith, $R$. Horsfieldii Miquel). It is therefore reasonable to separate the two plants specifically, although there occur connecting links in the Himalayas.

Rubus coreanus Miquel in Ann. Mus. Lugd.-Bat. III. 34 (1867); Prol. Fl. Jap. 222 (1866-67). - Focke in Bibl. Bot. LXXII. 184 (Spec. Rub.) (1911).

Western Hupeh: north and south of Ichang, alt. 300-1200 m., July 1907 (No. 3I); Chang-lo Hsien, alt. 1200 m., September 1907 (No. I52).

Rubus Kuntzeanus Hemsley in Jour. Linn. Soc. XXIII. 232 (1887). - Focke in Bibl. Bot. LXXII. 195 (Spec. Rub.) (1911).

Western Hupeh: north and south of Ichang, thickets, alt. 3001500 m., June and August 1907 (No. 92).

Rubus flosculosus Focke in Hooker's Icon. XX. text to t. 1952, p. 3 (1891); in Bibl. Bot. LXXII. 193 (Spec. Rub.) (1911).

Western Hupeh: Fang Hsien, thickets, alt. 1200-1500 m., June and September 1907 (No. I45).

Rubus flosculosus, f. parvifolius Focke, n. forma.

Western Hupeh: Chang-lo Hsien, thickets, alt. 900-1200 m., September 1907 (No. I45) 
Rubus flosculosus f. laxiflorus Focke, n. forma.

Western Szech'uan: Tachien-lu, alt. 1800-2400 m., October 1908 (No. 1246).

Rubus Giraldianus Focke in Bot. Jahrb. XXIX. 401 (1901); in Bibl. Bot. LXXII. 194, fig. 78 (Spec. Rub.) (1911).

Western Szech'uan: Wa-ssu country, Wên-chuan Hsien, thickets, alt. 1500-2200 m., July and August 1908 (No. 815).

Rubus adenophorus Rolfe in Kew Bull. Misc. Inform. 1910, p. 382.

Rubus sagatus Focke in Bibl. Bot. LXXII. 198, fig. 80 (Spec. Rub.) (1911).

Western Hupeh: Chang-lo Hsien, thickets, alt. 1200 m., June and July 1907 (No. 8I).

Rubus innominatus S. Moore in Jour. Bot. XIII. 226 (1875). Focke in Bibl. Bot. LXXII. 195 (Spec. Rub.) (1911).

Rubus innominatus, subsp. plebejus Focke, subsp. nov.

Rami petiolique floccoso-tomentelli. Folia rami fertilis omnia ternata; foliolum terminale fere quadratico-suborbiculare, diam. fere 5-6 cm. Calyces nunc rubro-setosi, nunc setoso-echinati, sepalis post anthesin fructum involucrantibus (sicut in typo); petala rosea (ex Wilson); ovaria tomentosa. Fructus rubri.

Western Hupeh: Ichang, roadsides, alt. 300-900 m., June and July 1907 (No. 42).

The pinnate leaves and narrower leaflets distinguish the typical plant. It may be a variable species, but it is at present impossible to decide if there exist clear limits between allied forms.

In general aspect the subsp. plebejus recalls many common European brambles.

Rubus chiliadenus Focke in Hooker's Icon. XX. text to t. 1952, p. 4 (1891); in Bibl. Bot. LXXII. 198 (Spec. Rub.) (1911).

Western Hupeh: Ichang, roadsides, alt. 600 m., August 6, 3907 (No. 3024).

Rubus pinfaensis Léveillé \& Vaniot in Bull. Soc. Agric. Sarthe 1904, 5. - Focke in Bibl. Bot. LXXII. 199, fig. 81 (Spec. Rub.) (1911).

Western Hupeh: Ichang gorge, cliffs, alt. 300 m., March 20, 1908 (No. 3024).

Very near $R$. ellipticus Smith, but perhaps specifically distinct. 
Rubus mesogaeus Focke in Bot. Jahrb. XXIX. 399 (1901); in Bibl. Bot. LXXII. 204, fig. 82 (Spec. Rub.) (1911).

Western Hupeh: north and south of Ichang, thickets, alt. 6001200 m., May and July 1907 (Nos. 52, 7r); Hsing-shan Hsien, thickets, alt. 1200 m., July 1907 (No. $\mathbf{5 2}^{\mathrm{a}}$ ).

Rubus mesogaeus, f. floribus roseis.

Western Szech'uan: Wa-ssu country, Wên-chuan Hsien, woodlands, alt. 1200-2400 m., June and September 1908 (No. I042); southeast of Tachien-lu, thickets, alt. 1800-2100 m., June 1908 (No. 30r3); Pan-lan-shan, west of Kuan Hsien, woodlands, alt. 2100-3300 m., June 1908 (No. 3015).

Rubus aurantiacus Focke in Bibl. Bot. LXXII. 211 (Spec. Rub.) (1911).

Western Szech'uan: Tachien-lu, thickets, alt. 2100-2700 m., September 1908 (No. 992).

Rubus vicarius Focke in Bibl. Bot. LXXII. 211 (Spec. Rub.) (1911).

Western Szech'uan: Wa-shan, thickets, alt. 1500-2100 m., July and September 1908 (No. 948).

It would be instructive to cultivate these two forms of the Idaeus-group.

MADDENIA Hook. f. \& Thoms.

Determined by E. KoEHNE.

Maddenia hypoleuca Koehne, n. sp.

Frutex 2-6-metralis; rami novelli glabri v. pulverulento-puberuli v. pubescentes dein saepe glabri fusci, biennes crassiusculi, nigrescenti-fusci saepe pulverulento-puberuli haud nitiduli; gemmae ovatae, $2 \mathrm{~mm}$. longae, glabrae, squamis interioribus sub anthesi auctis. Stipulae 6-13 mm. longae, lineares v. lanceolatae v. e basi orbiculari linearicaudatae, basi glanduloso-fimbriatae; petioli 2-4 mm. longi, eglandulosi, subtus glabri, supra in canaliculo initio pubescentes; lamina e basi obtusa v. cordata ovato-oblonga v. oblonga, sub anthesi $3-5.5$ cm. longa, $1.3-1.8 \mathrm{~cm}$. lata, demum in ramulis fertilibus $5-6.5 \mathrm{~cm}$. longa, $1.3-3.2 \mathrm{~cm}$. lata, in innovationibus $7.5-16 \mathrm{~cm}$. longa, $4.3-7.5$ cm. lata, sensim v. subito acuminata, duplicato-serrata dentibus 
denticulisque argutissime acuminatis, ima basi vero glandulis nonnullis stipitatis fimbriata, utrinque glaberrima, nervis utrinsecus 14-18, supra laete viridis, subtus albicans sed epapillosa, costa venisque ochraceis venarum reticulo debili leviter cinerascente. Racemi pedunculis $3-4 \mathrm{~cm}$. longis foliatis initio puberulis v. pubescentibus dein glabratis insidentes, $3-5 \mathrm{~cm}$. longi, basi $2 \mathrm{~cm}$. diam., densiflori, axi pubescente dein glabrato; bracteae calyces haud aequantes v. superiores pedicellis breviores, rotundatae, glanduloso-fimbriatae; pedicelli $4 \mathrm{~mm}$. longi pubescenti-hirtelli; cupula $4 \mathrm{~mm}$. longa, basi brevissime hirtella ceterum extus intusque glabra; sepala 10 inaequalia, longiores $3 \mathrm{~mm}$. longa, nulla petaloidea; flores viridescentes v. fusco-purpurascentes; stamina 23-30 quorum longiora 5-6 mm. longa; pistillum $9 \mathrm{~mm}$. longum, glabrum, stylus staminibus vix brevior; flores pistillo obsoleto munitos non vidi. Drupa $8 \mathrm{~mm}$. longa $5 \mathrm{~mm}$. diam. v. paullo major, nigra; putamen $9: 5: 4.5 \mathrm{~mm}$., carina levi costulisque paucis obliquis tenuibus munitum, pariete tenui fragili.

Western Hupeh: Hsing-shan Hsien alt. 1200-1800 m., May 1907 (No. 2850), alt. 1200-1500 m., May 10, 1907 (No. 2849); Fang Hsien, alt. 1500 m., July 1907 (No. 2848). ${ }^{1}$

\section{Maddenia hypoxantha Koehne n. sp.}

Frutex 3-6 metralis; ramuli novelli luteo-fusci minutissime pulverulento-puberuli sparsimque pubescenti-hirtelli, demum intense fusci, hirtelli, biennes sat crassi, nigricantes, glabri; gemmae crasse ovatae, $3-4.5 \mathrm{~mm}$. longae, squamis ciliatis ceterum glabrae, squamis interioribus sub anthesi auctis. Stipulae 10-20 mm. longae, lineares, glabrae, usque ad medium tenere glanduloso-serratae; petioli $3-6 \mathrm{~mm}$. longi, eglandulosi, adpresso-pilosi demum dense hirtelli; lamina e basi cordata v. in foliis supremis obtusa v. acuta oblonga, suprema oblongo-lanceolata v. lanceolata, sub anthesi $4-6.5 \mathrm{~cm}$. longa, 2-3 cm. lata, demum 9-16.5 cm. longa, 3-6 cm. lata, sensim v. subito acuminata, duplicato-serrata dentibus denticulisque argutissime acuminatis saepe flexuosis, ima basi glandulis paucis v. pluribus stipitatis glanduloso-fimbriata, supra glabra, subtus in costa nervisque strigulosa facie glabra, nervis utrinsecus 12-20, supra laete v. lutescenti-viridis, subtus initio pallidior dein lutescens epapillosa venarum reticulo

1 This and the two following species are represented also in Wilson's earlier collections by flowering specimens. Maddenia hypoleuca: Chang-yang, June 1901 (No. 429 in part). Maddenia hypoxantha: Mt. Omei, June 1904 (No. 4857). Maddenia Wilsonii: Chang-yang, June 1901 (No. 429 in part). AlFRED REHDER. 
debili intensius colorato, costa nervisque laete ochraceis. Racemi pedunculis circ. $4 \mathrm{~cm}$. longis foliatis pubescentibus insidentes, 1.5-2 $\mathrm{cm}$. longi, $1.8 \mathrm{~cm}$. diam. densiflori, axi pubescente demum breviter hirtello; bracteae inferiores calycem aequantes, superiores subbreviores, lanceolato-lineares, basi glandulis paucis stipitatis munitae, ochraceae; pedicelli 1-2 mm. longi, pubescentes; cupula $2.7 \mathrm{~mm}$. longa, brevissime hirtello-puberula, intus glabra; sepala circ. 10, inaequalia, 1.5-2.5 $\mathrm{mm}$. longa, extus parce pilosa intus glabra, nulla petaloidea; flores viridescentes; stamina c. 26 , ad $4.5 \mathrm{~mm}$. longa; pistillum $6 \mathrm{~mm}$. longum, glabrum, stylus stamina parum superans. Drupa $9 \mathrm{~mm}$. longa, $9 \mathrm{~mm}$. diam., nigra; putamen $7: 5: 3.7 \mathrm{~mm}$. ovatum acutiusculum, carina costulisque obliquis debilibus munitum, fragile.

Western Szech'uan, southeast of Tachien-lu, alt. 1800-2700 m., May and July 1908 (No. 909, mixed with flowering specimens of M. Wilsonii).

\section{Maddenia Wilsonii Koehne, n. sp.}

Frutex 1.3-3.3 m. altus; ramuli novelli dense ochraceo-hirtellotomentosi, biennes nigricantes v. intense fusci, glabri vix nitiduli; gemmae ovatae, $3 \mathrm{~mm}$. longae, tomentosae, squamis interioribus sub anthesi auctis. Stipulae 9-18 mm. longae, lanceolatae, ochraceae, basi glanduloso-fimbriatae, in innovationibus interdum oblique cordatorotundatae ac caudatae, herbaceae, magna ex parte fimbriatae; petioli 2-7 mm. longi, eglandulosi, dense ochraceo-tomentosi; lamina e basi acuta $\mathrm{v}$. cordata inverse oblonga $\mathrm{v}$. oblongo-oblanceolata, in ramulis florentibus $2-8 \mathrm{~cm}$. longa, $1-3.5 \mathrm{~cm}$. lata, in innovationibus demum 5-14 cm. longa, $2.8-3.5 \mathrm{~cm}$. lata, longe acuminata, inciso-duplicatoserrata dentibus denticulisque argutissime acuminatis angustis, ima basi glandulis stipitatis fimbriata, supra pilis adpressis rigidulis longiusculis conspersa v. rarius glabra, subtus in costa nervisque densissime, in facie laxius v. dense hirto-villosa, nervis utrinsecus 15-20, supra laete viridis, subtus sublutescens v. demum cinereo-subfusca, epapillosa, costa nervisque ochraceis. Racemi pedunculis 2.5-10 $\mathrm{cm}$. longis foliatis insidentes, $2-3 \mathrm{~cm}$. longi, $2 \mathrm{~cm}$. diam., ovati, densiflori, axi villoso-tomentoso; bracteae inferiores calyces paene aequantes, superiores pedicellis breviores, glanduloso-fimbriatae; pedicelli $3.5-5$ $\mathrm{mm}$. longi, rufescenti-hirtello-tomentosi; cupula $3.5-4 \mathrm{~mm}$. longa, breviter hirtella v. superne glabra, intus glabra v. subglabra; sepala 10-12 inaequalia, 1.7-3 mm. longa, extus parce pilosa v. glabra, nulla petaloidea; flores viridescentes; stamina $29-40$, ad $5.5-6 \mathrm{~mm}$. longa; 
pistillum c. 8-9 $\mathrm{mm}$. longum, glabrum, semel vidi pistillum obsoletum stylo subnullo stigmate obsoleto. Drupa ad $9 \mathrm{~mm}$. longa $6 \mathrm{~mm}$. diam., ovata, nigra. Putamen ut in praecedente.

Western Szech'uan: Mupin, alt. 1500-2500 m., May and June 1908 (No. 285I); southeast of Tachien-lu, alt. 1800-2700 m., May 1908 (No. 909, mixed with M. hypoxantha). Western Hupeh: Chang-yang Hsien, alt. 1200-1800 m., April and July 1907 (No. 63).

Of the genus Maddenia Hooker f. \& Thomson (in Hooker Jour. Bot. and Kew Gard. Misc. VI. 381 [1854]), only two species, both from the Himalayas, are enumerated in the Index Kewensis and its supplements. Wilson found in China three new species which have the deciduous and closely serrate leaves of Maddenia, while the closely related Pygeum has persistent entire leaves. These important distinguishing characters are not mentioned by Focke (in Engler and Prantl, Nat. Pflanzenfam. III. 1, 51), who also states there that the pistillate flowers have two carpels developing into two drupes. According to Hooker f. \& Thomson, however, their structure is quite different. The flowers with two pistils are staminate, and their pistils do not bear styles, but a sessile stigma, and contain only abortive ovules. The twin-fruits which these flowers produce attain only half the size of the normal fruits and form no seeds. The normal fruits originate from perfect flowers with a pistil bearing a long style and contain one seed, as only one of the two ovules develops. In the Chinese species I have never found two pistils in one flower. Flowers without exserted styles can be found only in very small numbers, and as far as I have examined these flowers, they contain only one pistil with a minute style and a rudimentary stigma. The presence of two pistils must therefore be considered as of less importance than the character of the foliage. "

A key to all the species is appended here:

\section{Clavis specierum omnium.}

Flores racemosi racemis $1.5-5 \mathrm{~cm}$. longis densifloris, pedicellis 1-5 mm. longis.

Folia subtus haud villosa.

Folia subtus albicantia glaberrima ........ 1. M. hypoleuca.

Folia subtus lutescentia in costa nervisque strigulosa. . 2. M. hypoxantha.

Folia subtus villosa.

Folia inciso-duplicato-serrata dentibus angustissimis. … 3. M. Wilsonii.

Folia ciliato-denticulata. . . . . . . . . 4. M. himalaica. ${ }^{1}$

Flores subcorymbosi pedicellis bipollicaribus. . . . . . 5. M. pedicellata. ${ }^{2}$

\section{PRUNUS L.}

Subgen. PADUS.

Determined by E. Koenne.

Prunus Buergeriana Miquel in Ann. Mus. Lugd.-Bat. II. 92 (1865); Prol. Fl. Jap. 24 (1866).

1 Maddenia himalaica Hooker f. \& Thomson in Hooker Jour. Bot. and Kew Gard. Misc. VI. 381, t. 12 (1854) (descriptio et tabula optimae).

Hima lay as: Sikkim, alt. 2400-3000 m., May and August, J. D. Hooker.

2 Maddenia pedicellata Hooker f., Fl. Brit. Ind. II. 318 (1878).

India: Mishmi Hills, Griffith. 
Laurocerasus Buergeriana C. K. Schneider, Ill. Handb. Laubholzk. I. 646 (1906).

In the Japanese type the axis of the racemes is densely velvety-hirtellous, while it is minutely velvety-puberulous in the following variety which may be described, as the species is new for the Chinese flora.

Prunus Buergeriana var. nudiuscula Koehne, n. var.

Arbor 8-metralis trunco $0.3 \mathrm{~m}$. diam.; ramuli vetustiores cinereonigricantes, novelli fusci, glabri v. ima basi minutim velutini. Foliorum stipulae ignotae; petioli $10-13 \mathrm{~mm}$. longi, eglandulosi, glabri; lamina subtus in dentibus 2 infimis biglandulosa glandulis planis fuscis, e basi cuneata obovato-oblanceolata v. late oblanceolata (5.5-9 cm.: 2.2-3.3 cm.), acuminata, argute minutim incumbenti-serrulata, supra glabra, subtus glabra v. in nervorum axillis barbulata, membranacea reticulo haud prominente, subtus haud papillosa. Racemi erecti absque pedunculo nudo $0.5-1 \mathrm{~cm}$. longo $4-7 \mathrm{~cm}$. longi, circ. 20-30-flori axi minutim puberulo-velutino; bracteae caducae, ignotae; pedicelli 1-2 $\mathrm{mm}$. longi, glabri; cupula patelliformis vix $4 \mathrm{~mm}$. lata, extus glabra, intus infra medium pilosa, cum sepalis sub fructu persistens; sepala cupulae circ. aequilonga triangularia, obtusa, margine vix denticulato-glandulosa; petala $3 \mathrm{~mm}$. longa, rotundata; stamina 10, majora $4 \mathrm{~mm}$. longa; stylus sepala circ. aequans, ut ovarium glaber. Fructus ignotus.

Western Hupeh : Fang Hsien, woodlands, alt. 1200-1800 m., May 20, 1907 (No. 2834).

Prunus venosa Koehne, n. sp.

Arbor 6-12-metralis trunco $0.20-0.45 \mathrm{~m}$. diam. Ramuli vetustiores cinereo-nigricantes glabri, novelli fusci, glabri v. ima basi minutim velutini. Foliorum stipulae ignotae; petioli 8-13 $\mathrm{mm}$. longi, eglandulosi, glabri; lamina subtus in dentibus 2 infimis biglandulosa glandulis planis majusculis fuscis, e basi late cuneata v. fere rotundata sat anguste obovata v. obovato-oblanceolata (6-11 cm.: 2.5$4.5 \mathrm{~cm}$.), acuminata, breviter argute serrata dentibus latiusculis rectis v. vix sursum curvatis, supra glabra, subtus semper fere in nervorum axillis fasciculato-barbata, initio membranacea, dein cartilaginea, jam sub anthesi venarum reticulo utraque pagina manifeste prominulo, subtus haud papillosa (sub microscopio). Racemi erecti, absque pedunculo $0.8-1.5 \mathrm{~cm}$. longo 3-9 $\mathrm{cm}$. Tongi, circ. 10-35 flori, axi dense velutino; bracteae caducae, ignotae; pedicelli 1-2.5 mm. longi, glabri; cupula patelliformis $3.5 \mathrm{~mm}$. lata, extus glabra, intus margine excepto pilosa, sub fructu cum sepalis persistens; sepala cupulae circ. aequilonga, triangularia obtusa, crebre denticulato-glandulosa; pe- 
tala vix $3 \mathrm{~mm}$. longa, rotundata; stamina 10 , majora $5 \mathrm{~mm}$. longa; stylus sepala circ. aequans, ut ovarium glaber. Fructus globosus circ. 6-7 $\mathrm{mm}$. diam.; putamen ovoideo-globosum, paene $5 \mathrm{~mm}$. longum, subapiculatum, haud compressum, obscure carinatum, laeve, pariete tenui fragili.

Western Hupeh : Fang Hsien, woodlands, alt. 1500-1800 m., May 1907 (No. I77, as to flowering branches; the fruiting branches belong to P. stellipila); north and south of Ichang, alt. 900-1500 m., May and July 1907 (No. 9I); Patung Hsien, woods, May (not seen) and July $1907\left(\right.$ No. 9 $\left.^{\mathrm{a}}\right)$; Chang-yang Hsien, woods, alt. 1200 m., September 1907 (No. I 18, only a sterile branch seen); north and south of Ichang, woodlands, alt. 900-1500 m., June 1907 (No. 2839, as to sterile branches; the flowering branches belong to $P$. brachypoda var. pseudossiori.)

\section{Prunus stellipila Koehne, n. sp.}

Arbor 6-7-metralis trunco $0.3 \mathrm{~m}$. diam.; ramuli vetustiores nigrofusci glabri, juniores intense fusci, glabri. Foliorum stipulae ignotae; petioli 9-13 mm. longi, eglandulosi, glabri; lamina subtus in dentibus 2 infimis biglandulosa glandulis parvulis planis fuscis, e basi acuta $\mathrm{v}$. fere rotundata elliptica $v$. anguste oblonga $(4.5-10 \mathrm{~cm} .: 2-3.5 \mathrm{~cm}$.), acuminata $v$. fere caudata, argutissime serrata dentibus longioribus angustioribus quam in $P$. venosa porrectis v. subincurvis, supra glabra, subtus pilis fasciculatis versus costam densioribus conspersa, cartilaginea venarum reticulo jam sub anthesi utraque pagina manifeste prominulo, subtus (sub microscopio) haud papillosa. Racemi erecti, absque pedunculo brevi circ. $4-5 \mathrm{~cm}$. longi, axi glabro v. minutissime puberulo-velutino; bracteae caducae, ignotae; pedicelli 1-2 mm. longi, glabri; cupula parva, patelliformis, extus glabra, intus fundo pilosa, sub fructu cum sepalis persistens; sepala cupulae circ. aequilonga, triangularia, obtusa, glanduloso-denticulata, glabra; petala ignota; stamina 10 filamentis sub fructu $2 \mathrm{~mm}$. longis; stylus ignotus. Fructus globosus circ. $5 \mathrm{~mm}$. diam.; putamen ovoideo-globosum $4 \mathrm{~mm}$. longum, acutiusculum, haud compressum, validiuscule carinatum laeve, pariete tenui fragili.

Western Hupeh: Fang Hsien, woodlands, alt. 1500-1800 m., August 1907 (No. I77, as to fruiting branches; the flowering branches belong to $P$. venosa).

Prunus perulata Koehne, n. sp.

Arbor 10-13-metralis trunco $0.3-0.4 \mathrm{~m}$. diam.; ramuli vetustiores intense fusco-cinerei, plus minus velutini v. glabri, juniores subfusci, 
subglabri v. velutini, ut racemorum pedunculi usque ad autumnum basi squamarum imbricatarum involucro $7-20 \mathrm{~mm}$. longo cincti. Foliorum stipulae ignotae; petioli $7-12 \mathrm{~mm}$. longi, eglandulosi, velutini; lamina subtus in dentibus 2 infimis biglandulosa glandulis majusculis planis fuscis, e basi late cuneata $\mathrm{v}$. fere rotundata oblongoobovata oblanceolata v. elliptica $(6.5-11.5 \mathrm{~cm} .: 2.7-4.2 \mathrm{~cm}$.), breviter v. fere caudato-acuminata, serrulata dentibus brevibus rectis v. subincurvis, supra in nervis velutina ceterum glabra, subtus parce, secus costam dense breviter hirtella, demum subcartilaginea venarum reticulo utraque pagina manifeste prominulo, subtus (sub microscopio) haud papillosa. Racemi erecti, absque pedunculo 1-20 mm. involucrum superante 5-6 cm., fructiferi ad $10 \mathrm{~cm}$. longi, axi velutino; bracteae caducae, ignotae; pedicelli $0.5-1.5 \mathrm{~cm}$. longi, velutini; cupula patelliformis, vix ultra $1 \mathrm{~mm}$. longa, $3.5 \mathrm{~mm}$. lata, extus glabra, intus pilosa, sub fructu cum sepalis persistens; sepala cupulae circ. aequilongae, late triangularia, obtusa, margine glandulosa, glabra; petala circ. $2 \mathrm{~mm}$. longa, obovato-rotundata; stamina 10, majora antheris tantum petala superantia; stylus sepala aequans, ut ovarium glaber. Fructus globosus, circ. $5 \mathrm{~mm}$. diam.; putamen ovatum, paene $5 \mathrm{~mm}$. longum, acutiusculum, vix compressum, obscure carinatum, laeve, pariete tenui fragili.

Western Szech'uan: Ching-chi Hsien, woodlands, alt. $1800 \mathrm{~m}$., May 1908 (No. 2842); Wa-ssu country, Wên-chuan Hsien, woods, alt. 1800-2100 m., August 1908 (No. 8II).

\section{Prunus microbotrys Koehne, n. sp.}

Arbor 10-metralis trunco $0.3 \mathrm{~m}$. diam., glaberrima, sempervirens. Foliorum stipulae ignotae; petioli $5 \mathrm{~mm}$. longi, lutescentes, eglandulosi; lamina e basi eglandulosa rotundata v. subito brevissime contracta ovato-oblonga $\mathrm{v}$. late oblonga $(6.5-9 \mathrm{~cm} .: 3-4 \mathrm{~cm}$.$) , infra$ medium latiora, caudato-acuminata, inde a quarta v. tertia parte dentibus brevibus utrinque circ. 8-12 serrata acumine integro, cartilaginea, laevis, supra laete viridis, haud nitens, subtus pallidior. Racemi axillares erecti, absque pedunculo nudo $1 \mathrm{~cm}$. longo $3.5-4 \mathrm{~cm}$. longi, circ. 8-16-flori; bracteae caducae, ignotae; pedicelli $2-3.5 \mathrm{~mm}$. longi, tenues; anthesis mense octobri; cupula patelliformis, vix 2 $\mathrm{mm}$. longa, $4 \mathrm{~mm}$. lata, extus glabra, intus parce pilosa, sepala interstitiis latiusculis sejuncta, triangularia, cupula dimidio breviora, ciliata atque utrinsecus saepe glandulas 1-2 globosas sessiles gerentia; petala circ. $4 \mathrm{~mm}$. longa, $3 \mathrm{~mm}$. lata, irregulariter erosa; stamina 
10-12, antheris tantum petala superantia; ovarium pilosiusculum; stylus cupulam vel petala aequans, glaber. Fructus ignotus.

Western Szech'uan: Ya-chu Fu, woodlands, alt. 1200 m., October 1908 (No. 2847).

From this species Prunus phaeosticta Maximowicz differs in the leaves being copiously and minutely punctulate beneath and from $P$. spinulosa Siebold \& Zuccarini in its narrower leaves broadest above or at the middle with nearly spinulose teeth curved forward, in the branchlets and racemes slightly pilose and in the stamens exceeding 20 in number; $P$. macrophylla Siebold \& Zuccarini, $P$. acuminata Roemer and $P$. Jenkinsii Hooker $\mathrm{f}$. differ in other characters as well as in the shape of their much larger leaves.

Prunus Wilsonii (Diels ms.) Koehne, n. comb.

Padus Wilsonii C. K. Schneider in Fedde, Rep. Sp. Nov. I. 69 (1905); Ill. Handb. Lautholzk. I. 637 (quoad ramos floriferos; excludendis ramis fructiferis qui ad $P$. sericeam Koehne pertinent) (1906).

The type as described by $\mathrm{C}$. K. Schneider differs in the axis of the racemes, the pedicels, the cupula and the sepals inside and outside being short-hirtellous and becoming glabrous. Besides, the petioles are described as without glands, the leaves as rather remotely serrulate, whitish beneath and the stamens as nearly twice as long as the petals. I have, however, after a comparison with Schneider's specimen, no doubt that the following variety belongs here.

Prunus Wilsonii, var. leiobotrys Koehne, $\mathrm{n}$. var.

Arbor 10 -metralis trunco $0.45 \mathrm{~m}$. diam. Racemorum axis pedicellique glabri; cupula extus glabra, sed sepala ut in typo utrinque hirtella ac ciliata. Glandulae 1-4 rarius petioli apici, saepius laminae ima basi insidentes; lamina densiuscule serrulata, subtus subcana. Stamina petalis dimidio longiora (stamina $6 \mathrm{~mm}$., petala $4 \mathrm{~mm}$.). Ceterum cf. supra clavem specierum.

Western Hupeh: Hsing-shan Hsien, ravines, rare, alt. $900 \mathrm{~m}$., May 7, 1907 (No. 2835); South Wushan, woods, alt. 1200 m., June (not seen) and September 1907 (No. 222); north and south of Ichang, woods, alt. 600-1200 m., September 1907 (No. I27, as to fruiting branches; the flowering branches belong to $P$. sericea, var. brevifolia).

To this variety seems to belong: Padus napaulensis (Ser.) C. K. Schneider forma? in Fedde, Rep. Nov. Sp. I. 68 (1905), collected in Yunnan by A. Henry (No. 10547). This form differs from $P$. Wilsonii, var. leiobotrys only in the fewer and shorter hairs on the under side of the leaves, and might be considered as intermediate between $P$. napaulensis and $P$. Wilsonii (not between $P$. napaulensis and $P$. sericea as Schneider suggests), but in numerous specimens of $P$.napaulensis the leaves are always glabrous beneath.

Prunus sericea Koehne, n. sp.

Prunus napaulensis, var. sericea Batalin in Act. Hort. Petrop. XIV.169 (1895). Padus napaulensis, var. sericea C. K. Schneider, Ill. Handb. Laubholzk. I. 639 (1906). 
Prunus sericea, var. Batalinii Koehne, n. var.

Arbor 5-metralis (Potanin) v. 13-22-metralis (Wilson); ramuli novelli glabri. Folia e basi rotundata v. acuta elliptica v. inverse oblonga (in innovationibus 9.5-13: 3-5.5 cm., in ramulis florentibus paullo minora), longitudine latitudinem saepe triplam aequante, durante 'evolutione subtus insigniter densissime candido-sericea, postea pilis perturbatis densis, sed paginam inferiorem haud abscondentibus cinereo-hirtella. Racemorum axes pedicellique tenere breviter pilosi, cupulae glabrae, sepala tenere ciliata, ceterum glabra; petala $4 \mathrm{~mm}$. longa, $3 \mathrm{~mm}$. lata, vix eroso-denticulata; stamina 27-32, ad $5 \mathrm{~mm}$. longa; stylus sepalis sublongior. Fructus $16 \mathrm{~mm}$. longus, subglobosus, niger; putamen ovatum, $12.9 \mathrm{~mm}$. longum, $8.6 \mathrm{~mm}$. diam. v. $10.8 \mathrm{~mm}$. longum, $8.8 \mathrm{~mm}$. diam. laeve.

Western Szech'uan: Ya-chu, April 7, 1893, G.N. Potanin; Washan, alt. 1200-1800 m., September 1908 (No. 222 ${ }^{\text {b }}$ ). Western Hupeh: Pao-k'ang, 1901 (Veitch Exped. No. 277, fruiting branches; the flowering branches of this No. belong to $P$. Wilsonii).

Prunus sericea, var. brevifolia Koehne, n. var.

Arbor 10-13-metralis trunco $0.45-0.60 \mathrm{~m}$. diam.; ramuli juniores basi interdum pulverulento-puberuli, ceterum glaberrimi. Folia e basi plerumque rotundata oblongo-obovata $\mathrm{v}$. obovata $\mathrm{v}$. late ovalia (5.5-9.5 cm.: $2.7-5 \mathrm{~cm}$.), longitudine latitudinis $2.3-2.6$ aequante, durante evolutione subtus tomento flavo-cinereo densissimo obtecta, venarum reticulo nigrescente conspicuo, postea ut in typo subtus pilis perturbatis densisque neque vero paginam inferiorem abscondentibus cinereo-hirtella. Racemi 9-12 cm. longi, axi pedicellis cupulis sepalis dense fuscescenti-hirtellis; pedicelli $4-5 \mathrm{~mm}$. longi; cupula $4 \mathrm{~mm}$. longa, $5 \mathrm{~mm}$. lata, profunda semiglobosa, intus glabra (ut in omnibus Pachypodii speciebus); sepala late breviter lingulata, apice rotundata, dense ciliata, glandulisque singulis margine obsita; in floribus nondum evolutis petala $4 \mathrm{~mm}$., stamina 32 circ. $5 \mathrm{~mm}$. longa, stylus sepala haud aequans, glaber. Fructus ignotus.

Western Hupeh: north and south of Ichang, woods, alt. 6001200 m., May 1907 (No. I27, as to flowering branches; the fruiting branches belong to $P$. Wilsonii, var. leiobotrys). ${ }^{1}$

${ }^{1}$ Another new variety, but not represented in the Wilson collection is the following :

Prunus sericea, var. septentrionalis Koehne, n. var.

Racemi axis pedicellique glaberrimi.

Northern Shensi: In-kia-po, G. Giraldi (No. 6081.) 
Prunus rufomicans Koehne, n. sp.

Arbor 20-30-metralis trunco $0.5-0.8$ in diam.; ramuli vetustiores intense fusci, glabri, juniores fusci, glabri. Foliorum stipulae ignotae; glandulae rarius petiolo, saepius 1-2 laminae basi insidentes, crassae; petioli in ramis fertilibus $5-10 \mathrm{~mm}$., in sterilibus $12-14 \mathrm{~mm}$. longi, glabri v. parce hirtelli; lamina e basi rotundata v. late cuneata in ramis fertilibus lanceolata $\mathrm{v}$. oblongo-lanceolata $(4.5-6 \mathrm{~cm} .: 1.5-2$ $\mathrm{cm}$.), in sterilibus late ovato-elliptica v. obovata $(9-10 \mathrm{~cm} .: 4.5-5.8$ cm.), subacuminata, argute dense v. subremote serrulata, supra glabra, subtus tomento sericeo paginam inferiorum perfecte abscondente densissimo intense rufo-ferrugineo submicante obtecta, supra venis impressis reticulato-rugosa, subtus nervis primariis valide prominentibus, subtus (sub microscopio) inter stomata vix papillosa, sed stomata papillis arcte confertis circumvallata fere abscondita. Racemi fructiferi circ. $12 \mathrm{~cm}$. longi, glabri; pedicelli $3-4 \mathrm{~mm}$. longi, ut axis insigniter incrassati pallideque lenticellati; cupulae basis persistens, intus glaberrima. Fructus subglobosus, circ. $10 \mathrm{~mm}$. diam.; putamen $9 \mathrm{~mm}$. longum, $7 \mathrm{~mm}$. diam., ovatum, acutum, obscure carinatum, laevissimum, durum.

Western Szech'uan: Mupin, woods, alt. 1500-1600 m., October 1908 (No. I078).

Prunus brachypoda Batalin in Act. Hort. Petrop. XII. 166 (1892); in Gartenfl. XLII. 330 (1893).

Padus brachypoda C. K. Schneider in Fedde, Rep. Nov. Sp. I. 69 (1905); Ill. Handb. Laubholzk. I. 638 (1906.) (excl. var. putigera quae speciem propriam sistit).

The varieties of this species may be described as their characters are partly rather uncertain.

Prunus brachypoda, var. pseudossiori Koehne, n. var.

Arbor 5-20-metralis trunco 20-60 cm. diam.; ramuli juveniles glabri v. raro pulverulento-puberuli. Petioli $11-40 \mathrm{~mm}$. longi, glabri, semper fere biglandulosi; lamina e basi manifeste cordata $\mathrm{v}$. in ramulis floralibus rotundata anguste $\mathrm{v}$. late oblonga, ovato-oblonga, obovatooblonga (3-12 $\mathrm{cm}$. longa, $0.8-5.5 \mathrm{~cm}$. lata), longiuscule argute acuminata, argutissime serrata dentibus angustis tenuiter acuminatis longiusculis (sed minoribus quam in $P$. ssiori), porrectis v. subincurvis, subtus in nervorum axillis barbata ceterum glabra, intermixtis saepe foliis omnino glabris, subtus parum pallidior quam supra reticulo tenerrimo intensius colorato, subtus nunc manifeste nunc haud pa- 
pillosa. Racemi absque pedunculo foliato $11-23 \mathrm{~cm}$. longi, sec. cl. Wilson plus minus penduli, glabri v. (saepe in racemis ex eodem ramo primario ortis) pulverulento-velutini; pedicelli $2-6 \mathrm{~mm}$. longi; cupula 2-3 mm. longa, 3-4.5 $\mathrm{mm}$. lata, intus infra medium villosa; sepala breviter glanduloso-fimbriata; petala $2-4.5 \mathrm{~mm}$. longa, rotundata v. obovato-rotundata, vix eroso-denticulata; stamina 18-33, majora petalis parum v. paullulum longiora; pistillum circ. $4 \mathrm{~mm}$. longum, glabrum, stylus sepala circ. aequans. Fructus ut videtur $5-7 \mathrm{~mm}$. diam.; putamen 4-5.5 mm. longum, 4-5 mm. diam., hinc carinatum, obsoletissime rugosum, durum.

Western Szech'uan: southeast of Tachien-lu, woodlands, alt. 1500-2200 m., June 1908 (No. 2843); Nin-tou-shan, west of Kuan Hsien, woodlands, alt. 1800 m., June 20, 1908 (No. 2846); Mupin, woodlands, alt. 1500-1800 m., August 1908 (No. 899); Nanch'uan, 1901, A. von Rosthorn; without locality, A. Henry (Nos. 5739, 5763). Western Hupeh: Hsing-shan Hsien, woods, alt. 1200-2300 m., July and August 1907 (No. I90); Changyang Hsien, woods, alt. 12001500 m., September 1907 (No. II5); north and south of Ichang, woodlands, alt. 900-1500 m., June 1, 1907 (No. 2839, as to flowering branches; the fruiting branches belong to $P$. venosa); without locality, A. Henry (No. 5988). Northern Shensi: G. Giraldi (Nos. 1141, 5200 ).

This variety is often confounded in collections with $P$. ssiori $\mathrm{F}$. Schmidt

Prunus brachypoda, var. microdonta Koehne, n. var.

Arbor 10-metralis trunco $40 \mathrm{~cm}$. diam. Petioli $12-26 \mathrm{~mm}$. longi, biglandulosi; lamina e basi rotundata $\mathrm{v}$. vix subcordata oblonga $\mathrm{v}$. lanceolata $(3.5-11 \mathrm{~cm}$. longa, 1.3-3.3 cm. lata), longe paullatim v. subcaudato-acuminata, minutim serrulata dentibus saepe quasi ad mucronem reductis porrectis v. incumbentibus, subtus glabra v. in axillis nervorum barbata, sub microscopio subtus scabrido-papillosa. Racemi 14-18 cm. longi, glabri; petala $3 \mathrm{~mm}$. longa, $2.5 \mathrm{~mm}$. lata; stamina c. 29 petalis parum longiora; pistillum $3 \mathrm{~mm}$. longum. Putamen 4-5 mm.: 4.5-5 mm.: $3.5 \mathrm{~mm}$. Cetera ut in var. pseudossiori.

Western Hupeh: Chang-lo Hsien, woods, alt. 1200-1500 m., April and September 1907 (Nos. 2836, 2838); without locality, 1901 (Veitch Exped. No. 2255).

Prunus obtusata Koehne, n. sp.

Arbor 8-13-metralis trunco $30-50 \mathrm{~cm}$. diam., ramuli juveniles 
basi glabri, apice pulverulento-velutini, vetustiores intense fusci haud nitentes, lenticellis pallidis sparsis. Petioli $10-20 \mathrm{~mm}$. longi, glabri, apice plerumque 1-2-glandulosi; lamina e basi rotundata $\mathrm{v}$. vix subcordata oblonga $\mathrm{v}$. inverse oblonga $\mathrm{v}$. ovato-oblonga (sub anthesi 3-7 $\mathrm{cm}$. longa $1.3-3.2 \mathrm{~cm}$. lata), nullo modo acuminata, obtusa v. obtusissima v. subemarginata, minutissime serrulata dentibus saepe ad glandulam reductis, glaberrima, supra laete viridis, subtus parum pallidior reticulo tenerrimo intensius colorato, epapillosa. Racemi erecto-patentes, absque pedunculo foliato 6-20 cm. longi, pulverulentovelutini v. puberuli; pedicelli $1-6 \mathrm{~mm}$. longi; cupula $2 \mathrm{~mm}$. longa, $3 \mathrm{~mm}$. lata, inferne pulverulenta, ceterum glabra, intus infra medium villosa; sepala $1 \mathrm{~mm}$. longa, obtusa, breviter glanduloso-fimbriata; petala 3-5 mm. longa, rotundata, subintegra; stamina 20-29, majora petala parum superantia $\mathrm{v}$. aequantia $\mathrm{v}$. iisdem triente breviora; pistillum 3-4.5 mm. longum, glabrum, stylus sepala circ. aequans. Fructus ignotus.

Western Szech'uan: Tachien-lu, woods, alt. 1800 m., May 1908 (No. 977 as to flowering branches; the fruiting branches belong to P. bicolor); Mupin, woodlands, alt. 1500-1800 m., June 1908 (No. 2845, as to flowering branches; the fruiting branches belong to $P$. pubigera); Wa-shan, woodlands, alt. 1800-2100 m., June 1908 (No. 2844).

This species seems to bear in its habit a rather striking resemblance to certain forms until now referred to $P$. demissa Walpers.

Prunus pubigera Koehne, n. sp.

Padus brachypoda, var. pubigera C. K. Schneider in Fedde, Rep. Nov. Sp. I. 70 (1905); Ill. Handb. Lautholzk. I. 638 (1906).

Arbor 6-20-metralis trunco 20-100 cm. diam.;-ramuli juveniles fuscescentes, puberulo-velutini, vetustiores validi, nigricantes v. purpureo-fusci, plus minus glabrati, lenticellis ovalibus pallidis; gemmae 5-8 mm. longae, conicae, fuscae, glabrae. Petioli 8-27 mm. longi, plerumque puberulo-velutini, saepissime 1-2-glandulosi; lamina e basi cuneata v. rotundata $\mathrm{v}$. cordata late inverse oblonga $\mathrm{v}$. obovatooblonga v. obovata (3-11.5 cm. longa 1.2-6 cm. lata), breviter leviter v. parum acuminata, apice obtusiuscula valide mucronata, minutim v. minutissime serrulata dentibus saepe fere ad glandulam reductis, supra glabra $\mathrm{v}$. in costa pulverulenta, subtus glabra v. in nervorum axillis subbarbata, supra laete viridis, subtus manifeste pallidior $\mathrm{v}$. subalbicans venis validioribus prominulis reticulo pallido v. rarissime intensius colorato, subtus haud v. breviter scabrido-papillosa. Racemi absque pedunculo foliato $7-14 \mathrm{~cm}$. longi, puberuli v. pulveru- 
lenti v. glabri; pedicelli $2-5 \mathrm{~mm}$., raro infimi ad $8 \mathrm{~mm}$. longi; cupula $3 \mathrm{~mm}$. longa, 4-4.5 mm. lata, intus infra medium villosa; sepala vix ultra $1 \mathrm{~mm}$. longa, obtusa, breviter glanduloso-fimbriata, ceterum glabra $\mathrm{v}$. tenerrime ciliata; petala 4-5 $\mathrm{mm}$. longa, $4 \mathrm{~mm}$. lata, subrotundata v. obovato-rotundata, integra v. leviter eroso-denticulata; stamina 21-28, majora petalis triente $\mathrm{v}$. paene dimidio breviora; pistillum 4-5 mm. longum, glabrum, stylus sepala parum superans. Fructus c. 5-8 mm. diam. ut videtur; putamen 4-6 mm. longum, 4-5 mm. diam., obsoletissime rugosum, durum.

\section{Prunus pubigera, var. Potaninii Koehne, n. var.}

Petioli puberuli; folia innovationum pleraque basi subcordata v. cordata, pleraque late inverse oblonga intermixtis paucissimis obovatis, omnia subtus haud v. vix papillosa. Sepala ciliata; petala $5 \mathrm{~mm}$., stamina majora $3 \mathrm{~mm}$. longa. Putamen 4-5 mm. longum, 4-5 mm. diam.

Tibet: G. N. Potanin. Western Szech'uan: southeast of Tachien-lu, woods, alt. 1800-2100 m., June and September 1908 (No. 980).

Prunus pubigera, var. Prattii Koehne, n. var.

Petioli subglabri v. glabri; folia innovationum pleraque basi cuneata v. rotundata, intermixtis vix ullis subcordatis v. obovatis, omnia subtus epapillosa. Racemi puberuli v. glabri; flores ignoti. Putamen 4-6 mm. longum, 4-5 $\mathrm{mm}$. diam.

Western Szech'uan: Tachien-lu, alt. 2700-4100 m., A. E. Pratt (No. 94); Mupin, woodlands, alt. 1500-1800 m., June 1908 (No. 2845, as to fruiting branches; the flowering branches belong to $P$. obtusata.). Western Hupeh: Fang Hsien, woods, alt. 1500-1800 m., August 1907 (No. I8I, remarkable for its glabrous racemes); Hsingshan Hsien, woods, alt. 1200-1500 m., September 1907 (No. 2837).

Prunus pubigera, var. obovata Koehne, $n$. var.

Petioli glabri; folia pleraque e basi vix unquam subcordata obovata, subtus haud v. vix papillosa. Racemi glabri v. puberuli; petala 4-5 $\mathrm{mm}$. longa; stamina majora vix ultra $3 \mathrm{~mm}$. longa. Putamen $5.5 \mathrm{~mm}$. longum, $5 \mathrm{~mm}$. diam.

Western Szech'uan: Wa-ssu country, Wên-chuan Hsien, woods, alt. 1800-2400 m., June 7, 1908 (No. I045). Western Hupeh : Fang Hsien, woods, alt. 1500-2100 m., August 1907 (No. 186, with glabrous racemes).

This variety seems similar in its habit to $P$. virginiana Linnaeus. 
Prunus bicolor Koehne, n. sp.

Ramuli novelli nigricantes, densissime puberulo-velutini, vetustiores vix glabrati lenticellis pallidis; gemmae $3.5-8 \mathrm{~mm}$. longae, pallide fuscae, glabrae. Petioli $15-25 \mathrm{~mm}$. longi, superiore pagina pulverulento-puberuli, eglandulosi; lamina e basi rotundata v. subcordata obovato-oblonga $(5.3-9.8 \mathrm{~cm}$. longa $2.5-4.5 \mathrm{~cm}$. lata), leviter breviter acuminata apice obtusiuscula valide mucronata, minutim serrata dentibus angustissimis porrectis v. subincurvis, supra in costa pulverulenta ceterum glabra, subtus glaberrima, supra intense viridis reticulo subimpresso, subtus manifeste albicans, costa nervisque ochraceis reticulo nigrescente maxime manifesto, sub microscopio circa stomata subpapillosa papillis scabridis. Racemi erecto-patentes, absque pedunculo foliato $13 \mathrm{~cm}$. longi, pulverulento-velutini; pedicelli 2-4.5 mm. longi. Flores ignoti. Cupulae basis sub fructu persistens, intus glaberrima. Fructus ut videtur 5-6 mm. diam.; putamen 4.3 $\mathrm{mm}$. longum, $4 \mathrm{~mm}$. diam., carinatum, obsoletissime rugosum.

Western Szech'uan: Tachien-lu, woods, alt. 1800 m., September 1908 (No. 977, as to fruiting branches; the flowering branches belong to $P$. obtusata.).

Prunus velutina Batalin in Act. Hort. Petrop. XIV. 186 (1895.)

Padus velutina C. K. Schneider in Fedde, Rep. Nov. Sp. I. 69 (1905); Ill. Handb. Laubholzk. I. 638 (1906).

Western Hupeh : north and south of Ichang, woodland, alt. 9001800 m., May and September 1907 (No. 2840); without locality, 1901 (Veitch Exped. No. 1789); A. Henry (No. 5774). Northern Shensi : G. Giraldi (No. 4931).

Prunus Grayana Maximowicz in Bull. Acad. Sci. St. Pétersbourg, XXIX. 107 (1884); in Mél. Biol. XI. 704 (1883).

Prunus Padus, var. japonica Miquel in Ann. Mus. Lugd.-Bat. II. 92 (1865)

Padus Grayana C. K. Schneider, Ill. Handb. Laubholzk. I. 640 (1906).

Padus acrophylla C. K. Schneider in Fedde, Rep. Nov. Sp. I. 70 (1905); Ill. Handl. Laubholzk. I. 640 (1906.) (Forsan ex descriptione huc etiam ducenda, quamvis cupulae basis sub fructu persistens ab autore dicatur pilosa.)

Petioli 5-13 mm. longi, eglandulosi; glandulae 1-3 marginales laminae dentibus infimis subtus insidentes, complanatae; folia e basi rotundata $\mathrm{v}$. vix subcordata late oblonga $\mathrm{v}$. obovato-oblonga $\mathrm{v}$. ovata, caudato-acuminata, argutissime serrata dentibus tenuissime acuminatis, subtus epapillosa. Pedicelli 2-13 mm. longi; cupula intus glaberrima; sepala integra, interdum margine parce glandulifera, ten- 
uiter ciliata; petala 3-5 mm. longa, ima basi lanato-barbata; stamina 23-32, majora petala aequantia v. superantia, 5-8 $\mathrm{mm}$. longa; stylus stamina circ. aequans.

Western Hupeh: Chang-yang Hsien, woodlands, alt. $1400 \mathrm{~m}$., May 1907 (No. 284I); without locality, 1901 (Veitch Exped. No. 604); A. Henry (No. 6327, according to C. K. Schneider in Herb. Reg. Berol., probably to be referred to $P$. ssiori F. Schmidt, but it is P. Grayana). Japan: Maximowicz (Iter Sec. 1861), 1862, Hilgendorf (No. 192), J. J. Rein, K. Shirai, K. Saida, U. Faurie (Nos. 376, 5009, 6054).

This species differs in several characters from the section Leptopodium, though in the herbarium it is often confounded with the very distinct $P$. ssiori. On account of its glands, the cupula glabrous on the inside and the entire or nearly entire sepals it seems to belong to the section Pachypodium rather than to Leptopodium.

\section{Prunus laxiflora Koehne, n. sp.}

Arbor 10-metralis trunco $40 \mathrm{~cm}$. diam.; ramuli juveniles puberuli, vetustiores vix glabrati, fusci v. nigricantes, lenticellis paucis parvis. Stipulae 5-10 mm. longae, anguste lineares, pubescentes; petioli 7-12 mm. longi, dense pubescentes, eglandulosi; glandulae 2 marginales dentium infimarum paginam inferiorem occupantes, complanatae; lamina e basi late cuneata late v. obovato-oblonga (sub anthesi 3.5-6 $\mathrm{cm}$. longa $1.6-2.7 \mathrm{~cm}$. lata), longe acuminata, inciso-subduplicato-serrata, dentibus longis tenuissime acuminatis, supra in costa pubescentivillosa, ceterum glabra, subtus in costa densius, in nervis laxius sericeovillosa, ceterum glabra, supra laete viridis, subtus vix pallidior reticulo intensius colorato, epapillosa. Racemi absque pedunculo efoliato, sed interdum hypophylla 1-2 parva gerente, 7-17 $\mathrm{mm}$. longo $4.5-7 \mathrm{~cm}$. longi, c. 6-12 flori, laxi, axi ac pedunculo adpresso-pubescente; bracteae infimae 10-4 $\mathrm{mm}$. longae, superiores usque ad $1 \mathrm{~mm}$. longitudinis decrescentes, omnes persistentes; pedicelli infimi $18 \mathrm{~mm}$., supremi $2 \mathrm{~mm}$. longi, laxe villosi; cupula circ. $3 \mathrm{~mm}$. longa ac lata, semigloboso-campanulata, extus basi tantum pilosa, intus glaberrima; sepala cupulae aequilonga, triangularia acuta, ut videtur horizontaliter patentia, longiuscule glanduloso-fimbriata; petala fere $7 \mathrm{~mm}$. longa, $4 \mathrm{~mm}$. lata, ovalia, margine leviter eroso-undulata; stamina 22-26, majora circ. $4 \mathrm{~mm}$. longa, petalis triente breviora; stylus stamina aequans v. paullo superans, ut ovarium glaber. Fructus ignotus. 
Western Hupeh: Hsing-shan Hsien, woods, alt. 1700 m., May 1907 (No. 62, as to flowering branches; the fruiting branches belong to $P$. discadenia Koehne, a new species of the section Phyllomahaleb.).

\section{DISPOSITIO PRUNI SUBGEN. PADI ET CLAVIS SPECIERUM CHINENSIUM.}

Calyx fructifer totus persistens; bracteae caducae; stylus brevis.

Sect. I. CALYCOPADUS.

* Pedunculi racemorum foliati (intermixtis interdum nonnullis nudis); folia decidua $\nabla$. sempervirentia. (Species omnes Americanae.)

* Pedunculi semper nudi; folia decidua. ..... Subsect. 2. CALYCINIA. † Ramuli racemorumque pedunculi basi haud involucrati.

Folia subtus glabra v. haud ubique pilosa.

Venarum reticulum supra nunquam, subtus nonnisi post anthesin prominulum. Folia supra medium latiora, incumbenti-serrulata.

P. Buergeriana.

Venarum reticulum jam durante anthesi utraque pagina manifeste prominulum; folia subtus in nervorum axillis multis barbulata ceterum glabra, majora latiora (6-11 cm.: 2.5-4.5 cm.) quam in $P$. stellipila, brevius serrata dentibus latioribus . . . . . . P. venosa.

Folia subtus ubique, versus costam densius, pilis fasciculatis conspersa, minora angustiora (4.5-10 cm.:2-3.5 cm.) quam in $P$. venosa, longius serrata dentibus angustioribus . . . . . . P. stellipila.

†† Ramuli ac pedunculi basi usque ad autumnum squamis involucrati,. involucro 7-20 mm. longa . . . . . . . . P. perulata. Calyx fructifer (ima basi excepta) deciduus . . . . . Sect. 2. GYMNOPADUS.

* Sempervirentes. Pedunculi nudi; bracteae caducae; stylus brevis.

Subsect. 3. LAUROCERASUS.

Petioli eglandulosi. Folia plerumque ovato-oblonga, caudato-acuminata, 6-9 cm. longa. Racemi glabri ... . . . . . P. microbotrys.

Petioli glandulosi. Folia oblonga, acuminata, 10-18 cm. longa. Racemi pubescentes . . . . . . . . P. macrophylla ${ }^{3}$

** Folia decidua.

† Pedunculi foliati (intermixtis interdum nonnullis nudis); bracteae caducae. . . . . . . . . . Subsect. 4. EUPADUS.

‡ Pedicelli fructiferi insigniter incrassati pallide lenticellati. Stylus brevis. (Folia in speciebus chinensibus subtus aequaliter pilosa.)

Ser. 1. PACHYPodrum.

Pagina inferior inter pilos nunquam rufos mox vel ab initio optime conspicua.

Pili transversi paralleli breves adpressi submicantes. . P. Wilsonii.

Pili mox subhirti perturbati (initio tantum tomentum sericeum candidum densissimum sistentes) . . . . . P. sericea.

1 Prunus macrophylla Siebold \& Zuccarini in Abhand. Akad. Münch. IV. pt. ii. 122 (Fam. Nat. Fl. Jap. 14) (1843).

Laurocerasus macrophylla C. K. Schneider, Ill. Handb. Laubholzk. I. 647, fig. 355 l. (1906).

So far only reported from eastern China (prov. Kwangtung). 
Pagina inferior usque ad mensem octobrem pilis perfecte abscondita, pilis tomentum sericeum intense rufo-ferrugineum submicantem sistentibus . . . . . . . . . . P. rufomicans.

$\ddagger \ddagger$ Pedicelli fructiferi nec incrassati nec lenticellati.

Stylus brevis . . . . . . . . . . Ser. 2. LePtopodruM.

Putamen manifeste rugosum. Petala 6-8 $\mathrm{mm}$. longa staminibus duplo longiora . . . . . . . . . . . P. Padus. ${ }^{1}$

Putamen laeve v. obsolete rugosum. Petala 3-4.5, raro ad $5 \mathrm{~mm}$. longa, staminibus aequilonga $v$. breviora, rarissime manifeste longiora.

Folia in acumen argutum plerumque longum producta.

Putamen $7 \mathrm{~mm}$. longum. Folia basi nonnulla rotundata, pleraque vero profunde cordata, argutissime serrata dentibus angustis longis tenuissime acuminatis, subtus nunquam papillosa; petioli 15-42 mm. longi, valide 2- (v. 1-6)-glandulosi. Racemi 10-17 $\mathrm{cm}$. longi, glabri; pedicelli 4-13 $\mathrm{mm}$. longi; petala $4.5 \mathrm{~mm}$. longa, staminibus aequilonga . . . . . . . . P. ssiori. ${ }^{2}$

Putamen 4-5.5 mm. longum. Folia basi rotundata $\nabla$. haud raro manifeste cordata, argute v. minutim serrata dentibus semper minoribus quam in $P$. ssiori, subtus nunc papillosa nunc epapillosa; petioli 11-24 $\mathrm{mm}$. longi, plerique glandulis 1-2 debilibus muniti. Racemi 12-23 cm. longi, nunc glabri nunc puberuli; pedicelli $2-6 \mathrm{~mm}$. longi; petala $2-4.5 \mathrm{~mm}$. longa, staminibus aequilonga v. vix breviora ....... P. brachypoda.

Folia leviter breviter v. haud acuminata, obtusiuscula mucronata v. obtusa v. subemarginata, semper brevissime v. minutim serrulata. Putamen 4-6 mm., raro $7 \mathrm{~mm}$. longum.

Folia subtus glaberrima v. nonnisi in nervorum axillis barbata; petala staminibus aequilonga $\mathrm{v}$. longiora.

Calyx intus pilosus, quare etiam calycis basis sub fructu persistens intus hirta. Petioli glandulosi.

Folia obtusa v. subemarginata, subtus glaberrima ac vix pallidiora quam supra, venarum reticulo tenerrimo haud prominulo intensius colorato . . . . . P. obtusata.

Folia plerumque leviter breviter acuminata apice obtusiuscula mucronata, subtus glaberrima $\mathrm{v}$. in axillis paullulum

1 Prunus Padus Linnaeus, Spec. 473 (1753).

Prunus racemosa Lamarck, Fl. Franc. III. 107 (1778).

Padus vulgaris Borkhausen, Forstbot. II. 1426 (1803).

Cerasus Padus De Candolle, Fl. Frans. IV. 580 (1805).

Padus racemosa C. K. Schneider, Ill. Hand. Laubholzk. I. 639, fig. $351 \mathrm{a}-\mathrm{h}$, 352 a (1906).

So far only reported from northern China, Mongolia, Shensi, and Chili.

2 Prunus ssiori F. Schmidt in Mém. Acad. Sci. St. Pétersbourg, sér. 7, XII. No. II. 124 (Reis. Amurland) (1868).

Padus ssiori C. K. Schneider, Ill. Handb. Laubholzk. I. 647 (1906).

Of this species I have seen specimens from Saghalin and Japan, and it is also reported from southern Mandshuria, but has not yet been collected in other parts of the Chinese Empire. C. K. Schneider has referred several specimens of $P$. Gray$a n a$ in the Berlin herbarium to $P$. ssiori, but these two species, though similar in the serration of the leaves, are otherwise very different and can always be easily distinguished with certainty. It is less easy to distinguish $P$. ssiori from $P$. brachypoda, var. pseudossiori. 
barbata atque plerumque manifeste pallidiora quam supra, nervis venisque primariis subtus prominulis, reticulo plerumque pallido rarissime intensius colorato. $P$. pubigera. Calycis basis sub fructu persistens intus glaberrima. Petioli eglandulosi. Folia subtus glaberrima, pallida albicantia, costa nervis ochraceis, reticulo multo intensius colorato distinctissimo . . . . . . . . . . . P. bicolor.

Folia tota pagina inferiore laxe pilosa pallida, reticulo pallido demum prominulo; petala staminibus triente breviora.

$P$. velutina.

Stylus longus. . . . . . . . . . Ser. 3. Grayopadus.

†† Pedunculi nudi; bracteae persistentes; stylus longus.

P. Grayana.

Ser. 4. MaAckiopadus.

A specie altera ${ }^{1}$ hujus sectionis foliis subtus eglandulosis, racemis 4-7 cm. longis laxifloris, sepalis fimbriatis stylo glabro differt.

$P$. laxiflora.

\section{SPECIERUM DISTRIBUTIO SYSTEMATICA}

Sect. 1. CALYCOPADUS Koehne in Abhand. Bot. Ver. Brandenburg, LII. 107 (1910).

Calyx persistens.

Subsect. 1. CAPOLLINIA Koehne in Abhand. Bot. Ver. Brandenburg, LII. 106 (1910).

Sect. Eupadus Koehne, Deutsche Dendr. 303 (pro parte) (1893).

Species sempervirentes vel foliis deciduis, venarum reticulo saepe indole rhombica. Pedunculi typice foliati; bracteae caducae. Calyx fructifer persistens. Stamina circ. 15-25 (an semper?); stylus brevis.

Species omnes americanae: $P$. salicifolia Kunth (Bolivia, Peru, Ecuador, Columbia, an Mexico?), P. Capollin (De Candolle) Koehne (Mexico), P. serotina Ehrhart cum var. neomontana Small (Amer. bor. ut sequentes), P. eximia Small, $P$. alabamensis Mohr, $P$. Cuthbertii Small, $P$. australis Beadle.

Subsect. 2. CALYCINIA Koehne in Abhand. Bot. Ver. Brandenburg, LII. 107 (1910).

Folia decidua, venarum reticulo isodiametrico, subtus in dentibus infimis biglandulosa. Pedunculi nudi; bracteae caducae. Calyx persistens; stamina 10(-12); stylus brevis.

Species omnes asiaticae: $P$. undulata Roemer (inde a Bengalia or. usque ad Nepal), $P$. venosa Koehne (China), $P$. stellipila Koehne (China), P. perulata Koehne (China), P. Buergeriana Miquel (China, Japonia).

1 Prunus Maackii Ruprecht in Bull. Acad. Sci. St. Pétersbourg, XV. 361 (1857).

Laurocerasus Maackii C. K. Schneider, Ill. Handb. Laubholzk. I. 645, fig. 352 h-i (1906).

Known from Amurland and Mandshuria, but not yet reported from other regions of the Chinese Empire. It differs from $P$. laxiflora in its leaves being glandular punctate beneath, in the dense racemes, $2-3 \mathrm{~cm}$. long, the bracts 1-2 mm. long, the scarcely fimbriate sepals and in the style being loosely villose below the middle. 
Sect. 2. GYMNOPADUS Koehne in Abhand. Bot. Ver. Brandenburg, LII. 107 (1910).

Calyx sub fructu deciduus.

Subsect. 3. LAUROCERASUS (Roem.) Koehne, Deutsche Dendr. 303 (excl. P. . Maackii) (1893).

Sempervirentes, venarum reticulo isodiametrico. Pedunculi nudi; bracteae caducae. Calyx fructifer deciduus. Stylus brevis.

Species americanae: P. brasiliensis Roemer (Brasilia), P. Brittoniana Rusby (Bolivia), P. Pearcei Rusby (Bolivia), P. guanaiensis Rusby (Bolivia), P. integrifolia Presl (Peru, Ecuador), P. occidentalis Roemer (Antillae), P. sphaerocarpa Roemer (Antillae, an Mexico?), $P$. reflexa Roemer (Antillae), P. samydoides Roemer (Mexico), $P$. laurifolia Schlechtendal (Mexico), $P$. ilicifolia Roemer (California), $P$. Lyonii Sargent ${ }^{1}$ (California), P. caroliniana Aiton (Amer. bor.).- Mediterraneae et macaronesicae: P. Laurocerasus Linnaeus, $P$. lusitanica Roemer. - Asiaticae: P. javanica Miquel (Java), P. martabanica S. Kurz (Java), P. acuminata Roemer (inde a Nepal usque ad Assam), P. Jenkinsii Hooker f. (Assam), P. phaeosticta Maximowicz (Khasia, China), P. microbotrys Koehne (China), P. macrophylla Siebold \& Zuccarini (China, Japonia), P. spinulosa Siebold \& Zuccarini (Japonia).

Subsect. 4. EUPADUS Koehne in Abhand. Bot. Ver. Brandenburg, LII. 107 (1910).

Sect. Eupadus Koehne, Deutsche Dendr. 303 (excl. P. serotina) (1893).

Folia decidua, venarum reticulo isodiametrico. Pedunculi typice foliati; bracteae caducae. Calyx fructifer deciduus. Stamina 20-35.

Ser. 1. Pachypodium Koehne in Abhand. Bot. Ver. Brandenburg, LII. 107 (1910).

Racemorum axes stricti pedicellique fructiferi insigniter incrassati, pallide lenticellati. Folia semper subtus valide papillosa, saltem stomata papillis arcte confertis circumvallata abscondita. Cupula semper intus glaberrima; stylus brevis; stamina plerumque ultra 30 .

Species omnes asiaticae: $P$. napaulensis Steudel (Himalaya,) $P$. bracteopadus Koehne (Himalaya), P. Wilsonii (Diels apud C. K. Schneid.) Koehne (China), $P$. sericea (Batalin) Koehne (China), $P$. rufomicans Koehne (China).

Ser. 2. Leptopodiom Koehne in Abhand. Bot. Ver. Brandenburg, LII. 107 (1910).

1 Prunus Lyonii (Eastwood) Sargent, nov. comb.

Prunus occidentalis Lyon in Bot. Gazette, xi. 202, 333 (not Swartz) (1886).Greene in Bull. Cal. Acad. ii. 395.

Prunus ilicifolia, var. occidentalis Brandegee in Proc. Cal. Acad. ser. 2, i. 209 (1888).

Prunus ilicifolia, var. integrifolia Sudworth in Garden and Forest, iv. 51 (1891). - Sargent, Silva N. Am. iv. 54. - Jepson, Silva of California, 253.

Prunus integrifolia (Sudworth) Sargent, Man. 531, f. 441 (not Walpers) (1905). Cerasus Lyonii Eastwood, Trees of California, 54 (1905).

Laurocerasus integrifolia (Sudworth) C. K. Schneider, Ill. Handb. Laubholzk. i. 648 (1906).

Laurocerasus Lyonii (Eastwood) Britton, Trees N. Am. 512 (1908).

C. S. S. 
Racemorum fructiferorum axes pedicellique haud vel vix incrassati nec insigniter pallide lenticellati. Folia subtus plus minus vel haud papillosa. Cupula intus plerumque saltem basi pilosa, rarius glabra. Stamina (14-)20-35. Stylus brevis.

Species americanae: $P$. virginiana Roemer (Amer. bor.), $P$. demissa Nuttall apud Torrey and Gray (Amer. bor.). - Europaeo-asiaticae: P. Padus Linné (inde ab Europa usque ad Sachalin). - Asiaticae: $P$. cornuta Steudel (inde ab Afghanistan usque ad Sikkim), $P$. anadenia Koehne (Afghanistan), $P$. glaucifolia Koehne (Himalaya), $P$. diversifolia Koehne (Korea), $P$. brachypoda Batalin (China, Tibet), $P$. velutina Batalin (China), P. bicolor Koehne (China), P. ssiori F. Schmidt (Mandschuria, Sachalin, Japonia).

An hujus sedis?: species koreanae $P$. seoulensis Léveille, $P$. diamantinus Léveillé, $P$. Fauriei Léveillé.

Ser. 3. Grayopadus Koehne in Abhand. Bot. Ver. Brandenburg, LII. 107 (1910).

Sect. Eupadus Koehne, Deutsche Dendr. 303 (pro parte) (1893).

Axes racemorum pedicellique fructiferi nec incrassati nec lenticellati. Folia subtus haud papillosa in dentibus infimis biglandulosa (ut in subsect. Calycinia). Cupula intus glaberrima; stamina circ. 22-26; stylus longus.

Species asiatica: P. Grayana Maximowicz (China, Japonia) cum Padus acrophylla C. K. Schneider chinensi verisimillime nullo modo diversa.

Subsect. 5. MAACKIOPADUS Koehne in Abhand. Bot. Ver. Brandenburg, LII. 107 (1910).

Folia decidua venarum reticulo isodiametrico. Pedunculi nudi; bracteae persistentes. Calyx magis campanulatus quam in subsect. 1-4, fructifer deciduus; stamina c. 20-30; stylus longus stamina aequans v. paullo superans.

Species omnes asiaticae: $P$. Maackii Ruprecht (Mandschuria, regio amurensis), $P$. laxiflora Koehne (China). 


\title{
AQUIFOLIACEAE.
}

\author{
ILEX L.
}

Determined by Th. Loesener.

Ilex rotunda Thunberg, $\mathrm{Fl}$. Jap. 77 (1784). - Loesener in Nov. Act. Leop.-Carol. LXXVIII. 106 (1901).

Kiangsi: Kiu-kiang, thickets of foot hills, alt. 300 m., August 2, 1907 (No. I6II).

Ilex purpurea Hasskarl, var. a Oldhamii Loesener in Nov. Act. Leop.-Carol. LXXVIII. 112 (1901).

Ilex Oldhamii Miquel in Ann. Mus. Lugd.-Bat. III. 105 (1867).

Western Hupeh: north and south of Ichang, woodlands, alt. 300-1000 m., June and December 1907 (Nos. 689, 3097). Western Szech'uan: Kiu-ting Fu, thickets, alt. 600-900 m., November 1908 (No. 3096).

Ilex pedunculosa Miquel, forma, $\beta$ continentalis Loesener in Nov. Act. Leop.-Carol. LXXVIII. 108 (1901).

Kiangsi: Kuling, side of streams, alt. 1200 m., July 30, 1907 (No. r6o9). Western Hupeh: north and south of Ichang, woodlands, alt. 900-1500 m., June 1907 (No. 477); Patung Hsien, woodlands, alt. 300-900 m., June 1907 (No. 3095).

Ilex yunnanensis Franchet, Pl. Delavay. II. 128 (1899). - Loesener in Nov. Act. Leop.-Carol. LXXVIII. 131 (1901).

Western Szech'uan: Wa-ssu country, Wên-chuan Hsien, thickets, alt. 1500-2000 m., June and September 1908 (Nos. ro24, 3092, 3094); Nin-tou-shan, west of Kuan Hsien, thickets, alt. 1200-1500 m., June 19, 1908 (No. 3093).

Ilex metabaptista Loesener in Nov. Act. Leop.-Carol. LXXVIII. 238 (1901).

Western Hupeh: Chang-yang Hsien, side of streams, alt. 300-600 m., May and December 1907 (No. 756). 
Ilex Fargesii Franchet in Jour. de Bot. XII. 255 (1898). - Loesener in Nov. Act. Leop.-Carol. LXXVIII. 239 (1901).

Western Hupeh: Hsing-shan Hsien, woods, alt. 1200-2100 m., May and September 1907 (No. 23I). Western Szech'uan: Mupin, woodlands, alt. 1500-2000 m., June 1908 (No. 3098).

Ilex Fargesii, var. v. forma, $\beta$ megalophylla Loesener, $n$. forma.

Foliis majoribus praecipue latioribus, usque $15 \mathrm{~cm}$. longis et $4.1 \mathrm{~cm}$. latis, petiolo usque $2.1 \mathrm{~cm}$. longo, a typo recedens.

Western Szech'uan: Wa-ssu country, Wên-chuan Hsien, woodlands, alt. 1500 m., July and September 1908 (No. ro34).

Ilex Franchetiana Loesener, n. sp.

Frutex 2-3 metralis, glaber v. glaberrimus. Ramuli i. s. brunneonigrescentes, vel cinereo-fuscescentes, hornotini i. s. angulati vel striato-subsulcati, laeves, 2-6 mm. crassi. Folia interstitiis, 4-18 mm. longis dissita; stipulis 0 vel valde fugacibus, modice $v$. longiuscule (7-19 mm. longe) petiolata; petiolo quam lamina circ. 5-10-plo breviore, supra medio profunde longitudinali-sulcato; lamina angustissime decurrente marginato, marginibus superne conniventibus v. erectis, 1-2 $\mathrm{mm}$. crasso, obovato-elliptica usque oblanceolata rarius lanceolato-elliptica, margine i. s. anguste v. angustissime recurvato, densius v. remotius et argute serrulato, iuxta basin saepe integro, basi cuneata v. raro cuneato-subobtusa, apice manifeste et acute v. acutiuscule acuminata, acumine usque $19 \mathrm{~mm}$. longo, 7-12.5 cm. longa, 1.7-3.5 cm. lata, chartacea usque coriacea, glabra, i. s. supra nitidula v. vix nitidula, cinereo-olivacea usque subatro-brunnea, subtus paullulo pallidiora, costa media supra i. s. impressa vel insculpta, subtus expressa, nervis lateralibus utrinque circ. $7-10$ sub angulo circ. $30-50^{\circ}$ obviis, rectis et iuxta marginem ad apicem versus curvatis raro leviter et sub- -formiter arcuatis, tenuibus, supra plane obsoletis v. vix prominulis, v. sub lente tenuissime et obsolete insculptis, subtus tenuiter prominentibus v. prominulis iuxta marginem laxius et saepe obsolete reticulatis, reticulo supra inconspicuo. Inflorescentiae in foliorum axillis fasciculatae, of 1-florae vel semel dichotomae, 2-3-florae, \& 1-florae, glabrae, pedunculis in $\sigma^{t}$ brevissimis, sub alabastris vix $1 \mathrm{~mm}$. longis, bracteis deltoideis vel ovato-deltoideis obtusis vel acutis 1-1.5 $\mathrm{mm}$. longis, pedicellis in $\$$ usque $4 \mathrm{~mm}$. longis, prophyllis medio v. sub medio pedicello insertis, bracteis similibus integris; flores 4-meri vel 4-5-meri; calycis lobi late ovato-deltoidei, obtusi v. rotundati, vix $1 \mathrm{~mm}$. longi et circ. $1 \mathrm{~mm}$. lati, sub lente valida tenuissime 
et parce ciliolati; corollae $f$. $\&$ petala albida ovata vel ovalia, sublibera, circ. $3 \mathrm{~mm}$. longa, fl. $\delta$ tantum alabastra visa; stamina fl. $\delta$ tantum in alabastra visa; staminodia fl. $\%$ petalis vix breviora, libera v. sublibera, antheris sterilibus apice intrusis, subcordiformibus, filamento multo brevioribus; ovarium fl. $\%$ subovoideum obsolete longitudinali-4-sulcatum, stigmate crassiusculo et discoidea obsolete 4-lobo coronatum, circ. $2.75 \mathrm{~mm}$. longum, 4-loculare etc. Drupa globosa, stigmate discoideo coronata, circ. $6 \mathrm{~mm}$. diam., in vivo rubra v. scarlatina, i.s. rugosa et plus minusve striato-sulcata, exocarpio tunicato, mesocarpio carnoso, 4-pyrena, pyrenis subtrigonis, dorso striato-sulcatis, $5 \mathrm{~mm}$. longis et circ. $3 \mathrm{~mm}$. latis, ligneis valde duris etc.

Western Hupeh: Changyang Hsien, woodlands, alt. 1200-1800 m., May and September 1907 (No. 148). Western Szech'uan: southeast of Tachien-lu, woods, alt. 2400 m., June and October 1908 (No. 1257).

This species is closely related to $I$. Fargesii Franchet, which differs in the shape of the leaves. These are entire or mostly entire below the middle, with longer bases gradually narrowed into the petioles, and at the apex are narrowed into a shorter and broader point. It forms a transition between the sections Microdontae and Repandae, and might perhaps be better placed in the latter, although I have placed it with the Lemurenses on account of its close relationship with I. Fargesii.

Ilex Aquifolium Linnaeus, var. c chinensis Loesener in Nov. Act. Leop.-Carol. LXXVIII. 263 (1901).

Western Hupeh: Ichang, cliffs in glens, etc., alt. 300-600 m., March 27, 1907 (No. 3I00).

Ilex Pernyi Franchet in Nouv. Arch. Mus. Paris, sér. 2, V. 221 (Pl. David. I. 69) (1883). - Oliver in Hooker's Icon. XVI. t. 1539 (1886). Loesener in Nov. Act. Leop.-Carol. LXXVIII. 278 (1901).

Western Szech'uan: southeast of Tachien-lu, alt. 2100 m., July 18, 1908 (No. II9). Western Hupeh: north and south of Ichang, mountain sides, alt. 1200-1800 m., May 14 and September 1907 (No. II9 in part).

Ilex cornuta Lindley \& Paxton, Flow. Gard. I. 43, fig. 27 (1850). Loesener in Nov. Act. Leop.-Carol. LXXVIII. 280 (1901).

Kiangsi: Kiu-kiang, abundant, alt. 150 m., August 2, 1907 (No. I608). Western Hupeh: Ichang, ravines and hill-sides, alt. 300600 m., May 1907 (No. 3Ior).

Ilex ciliospinosa Loesener, $\mathrm{n}$. sp.

Frutex 1-4-metralis. Ramuli erecti v. patentes, vetustiores teretes, 
cortice sordide griseo dense rimuloso et asperulo obtecti, triennes 4-5 $\mathrm{mm}$. crassi, hornotini dense et breviter subvillosulo-hirtelli, tarde $\mathrm{v}$. non glabrescentes, obsolete longitudinali-striolati. Folia usque quartum in annum in ramulis remanentia, interstitiis usque $11 \mathrm{~mm}$. longis dissita; stipulis e basi crassa subulatis plus minus persistentibus, callosis vix $1 \mathrm{~mm}$. longis, interdum indumento reconditis, brevissime (1-vix $2 \mathrm{~mm}$. longe) petiolata; petiolo quam lamina 15-38-plo breviore, supra medio longitudinali-impresso; lamina anguste decurrente marginato, sub lente valida saepe pulvereo-puberulo v. subglabro, basi usque $1.5 \mathrm{~mm}$. crasso, parvula, ovalia v. ovata usque oblonga, margine anguste recurvato, spinose denticulato-serrato, denticulis porrectis in spinulas singulas ciliiformes 1-2 $\mathrm{mm}$. longas angustatis, basi obtusa v. cuneato-obtusa raro subcuneata, apice acuta v. subacuminata et plerumque in spinulam angustata, $2.5-3.8 \mathrm{~cm}$. longa, 1-1.8 cm. lata, coriacea $\mathrm{v}$. tenaciter et rigidule coriacea, i. s. supra nitidula, brunneov. subflavo-olivacea, subtus vix pallidiora, glabra, costa media supra insculpta, subtus prominente, nervis lateralibus utrinque circ. 4-7 sub angulo $40-60^{\circ}$ patentibus, rectis v. plerumque paullulum ad basin versus arcuatis v. plus minusve sub- -formiter curvatis, iuxta marginem laxe reticulatis, supra tenuissime insculptis v. plane obsoletis, subtus prominentibus vel prominulis, reticulo subtus prominulo. Inflorescentiae in foliorum axillis fasciculatae, $\$$ tantum notae, 1 -florae, pedicellis sub drupa brevissimis, vix $2 \mathrm{~mm}$. longis, sub lente brevissime pulvereopuberulis, prophyllis medio pedicello insertis, crassis v. subscariosis, deltoideis et basi utrinque unidenticulatis, sub lente valida parce et breviter ciliolatis, 1-1.25 $\mathrm{mm}$. longis; flores ovario bimero excepto 4-meri, ipsi ignoti; calyx sub drupa 4-lobus, 2-3 mm. diam., lobis late deltoideis obtusis v. subrotundatis, circ. $1 \mathrm{~mm}$. longis, paene $2 \mathrm{~mm}$. latis. Drupa i. s. ellipsoidea, stigmate discoideo coronata, i. v. rubra, i. s. rugosa, circ. $7 \mathrm{~mm}$. longa, 5-6 mm. lata, exocarpio tunicato, mesocarpio carnoso, 2-pyrena, pyrenis subsemiovoideis (i. e. forma dimidiae ovi medio longitudinaliter persecti parti similibus), circ. $5.5 \mathrm{~mm}$. longis, $3-4 \mathrm{~mm}$. latis, lignescentibus et tenacibus, longitudinaliter a basi ad apicem dorso subpalmatim 5 -striolatis, ventre circ. 2-striolatis, seminibus non visis.

Western Szech'uan: Chien-shi Hsien, woodlands, alt. $1500 \mathrm{~m}$., September 15, 1908 (No. 996); Wa-shan, thickets, alt. 1500 m., October 1908 (No. 996a).

Most nearly related to $I$. dipyrena Wallich, which differs in the leaves being more than twice as large and in its glabrous or at least nearly glabrous branchlets. 
Ilex corallina Franchet in Bull. Soc. Bot. France, XXXIII. 452 (1886); Pl. Delavay. II. 127 (1889). - Loesener in Nov. Act. Leop.Carol. LXXVIII. 327 (1901).

Western Hupeh: Ichang, ravines, alt. 300-600 m., March 20 and June 1907 (No. 6). Western Szech'uan: Mupin, thickets, alt. 1200-1800 m., November 1908 (No I269)

Ilex szechwanensis Loesener in Nov. Act. Leop.-Carol. LXXVIII. 347 (1901).

Western Hupeh: south of Ichang, thickets, alt. 1200 m., October 1907 (No. 46r).

Ilex Wilsonii Loesener in Nov. Act. Leop.-Carol. LXXXIX. No. I. 287 (1908).

Kiangsi: Kuling, thickets, alt. 1200 m., July 31, 1907 (No. I6ro).

Ilex subrugosa Loesener, $\mathrm{n}$. sp.

Frutex 1.5-2 m. altus. Ramuli recti, erecti v. patentes, vetustiores demum subteretes, iuniores i. s. longitudinaliter striato-subangulati, biennes circ. $3.5 \mathrm{~mm}$. crassi, hornotini $2-2.5 \mathrm{~mm}$. crassi, sub lente dense sed brevissime pulvereo-puberuli. Folia usque tertium in annum (etiam diutius?) in ramulis remanentia, interstitiis usque $13 \mathrm{~mm}$. longis dissita, stipulis minutis, triangularibus, callosis, persistentibus sed postea oblitteratis, breviuscule (4-8 $\mathrm{mm}$. longe) petiolatis, petiolo quam lamina circ. 7-9-plo breviore, sub lente valida minute et brevissime pulvereo-puberulo, supra acute sulcato; lamina angustissime decurrente marginato, circ. $1 \mathrm{~mm}$. crasso, lanceolata vel ovato- vel oblongo-lanceolata, raro suboblanceolata, margine i. s. anguste recurvato, dense serrulato, basi cuneata v. acuta, apice sensim et obtusiuscule v. subacute acuminata, acumine usque $13 \mathrm{~mm}$. longo, 4.5-8 cm. longa, $1.2-2.1 \mathrm{~cm}$. lata, coriacea, supra nitida v. nitidissima, brunneo-olivacea, subtus pallidiora, non v. vix nitidula, costa media supra insculpta, subtus prominula v. vix prominente, nervis lateralibus utrinque circ. $5-7$, sub angulo $45-65^{\circ}$ patentibus, subrectis v. obsolete ad basin versus curvatis, supra plane obsoletis v. rarius conspicuis et sub lente tenuissime insculptis, subtus vix prominulis vel obsoletis, iuxta marginem laxe reticulatis, reticulo subtus vix prominulo v. plerumque plane inconspicuo, epidermide subtus saepius plicato-rugulosa. Inflorescentiae $\$$ tantum notae, in foliorum axillis pauci fasciculatae, v., si maris, axi communi evoluto brevi usque circ. $5 \mathrm{~mm}$. longo in pseudoracemum brevissimum dispositae, singulae uni- 
florae, sub lente valida brevissime et minute pulvereo-puberulae, pedicellis 3-4 mm. longis, basi biprophyllatis, prophyllis deltoideis acutis, dorso medio plus minusve carinatis et sub lente brevissime pilosulis, circ. $1 \mathrm{~mm}$. longis; flores ex drupa 4-meri; calyx sub drupa 4-lobus, 2-2.5 mm. diam., lobis late deltoideis obtusis vel rotundatis, integris, $0.5-0.75 \mathrm{~mm}$. longis, circ. $1.5 \mathrm{~mm}$. latis. Drupa late ellipsoidea, stigmate discoideo, obscuro, 4-lobo coronata, in vivo rubra, i. s. griseofusca et obsolete rugosa, circ. $5 \mathrm{~mm}$. longa, 4-4.5 $\mathrm{mm}$. lata, exocarpio tunicato extrinsecus sub lente valida tenuissime subtuberculatoruguloso, mesocarpio tenui carnoso, 4-pyrena, pyrenis circ. $3.5 \mathrm{~mm}$. longis, $1.75 \mathrm{~mm}$. latis, trigonis, longitudinaliter paucistriolatis et impresso-subsulcatis, tenacibus, lignescentibus.

Western Szech'uan: Mt. Wa-wu, Hong-yah Hsien, alt. 1200 m., September 1908 (No. 3099).

This species is perhaps better referred to the section Microdontae, but this must remain undecided, until the $\delta$ inflorescence is known. The lustrous leaves with the midribs impressed on their upper surface, the nearly obsolete veins and the plicate-rugulose epidermis of the lower surface indicate, however, that it may belong with the section Rugosae.

Ilex macrocarpa Oliver, var. a genuina Loesener in Nov. Act. Leop.Carol. LXXVIII. 491 (1901).

Western Hupeh: Chang-yang Hsien, alt. 600-1000 m., November 1907 (No. I5I, in part); north and south of Ichang, alt. 600-1000 m., May 3 and October 1907 (No. I5I, in part); Patung Hsien, roadsides, etc., alt. 300-900 m., May 1907 (No. 3089, in part).

Ilex macrocarpa, var. $\beta$ trichophylla Loesener, l. c. (1901).

Western Hupeh: north and south of Ichang, alt. 600-1000 m., May 3 and October 1907 (No. I5I, in part); Patung Hsien, roadsides, etc., alt. 300-900 m., May 1907 (No. 3089, in parte).

The specimens distributed under Nos. 151 and 3089 represent partly the typical form and partly this variety, which differs in its longer pedicels and in the leaves being pubescent beneath from the typical form with its shorter pedicels and glabrous leaves.

Ilex Henryi Loesener in Nov. Act. Leop.-Carol. LXXVIII. 491 (1901).

Western Szech'uan: near Wa-shan, alt. 600-900 m., June 1908 (No. 3088).

Ilex fragilis Hooker f., à genuina Loesener in Nov. Act. Leop.-Carol. XXVIII. 493 (1901).

Western Szech'uan: Wa-shan, woods, alt. 2400 m., September 15, 1908 (No. 892). 
Ilex fragilis, $\beta$ Kingii Loesener in Nov. Act. Leop.-Carol. XXVIII. 493 (1901).

Western Szech'uan: southeast of Tachien-lu, woods, alt. 18002300 m., June and October 1908 (No. 892 ${ }^{\mathrm{a}}$ ).

Ilex dubia Britton, Sterns \& Poggenburg, var. e pseudomacropoda Loesener, n. var.

Ramulis abbreviatis crassis usque $4.5 \mathrm{~cm}$. longis, foliis subtus glabris a var. macropoda diversa quacum ceterum congruens.

Western Hupeh: Hsing-shan Hsien, woods (only one tree seen), alt. 2100 m., May 31, 1907 (No. 3090).

No. 664 is represented only by a leafless fruiting branch and cannot be positively identified without leaves; it belongs either to Ilex micrococca Maximowicz or to a closely allied species. 


\title{
ACERACEAE.
}

\author{
Determined by Alfred ReHder.
}

\section{DIPTERONIA Oliver.}

Dipteronia sinensis Oliver in Hooker's Icon. XXIX. t. 1898 (1889).

Western Hupeh: north and south of Ichang, woodlands, alt. 900-1800 m., June 1907 (No. 883, in part); Chang-lo Hsien, alt. 9001800 m., September 1907 (No. 883, in part); Hsing-shan Hsien, alt. 900-1600 m., July 1907 (No. 883, in part); Patung Hsien, alt. 1600 m., June 1907 (No. 883, in part). Western Szech'uan: Mupin, woods, alt. 1200-1800 m., September 1907 (No. 883, in part).

The fruits of the specimens from Mupin are somewhat larger and sometimes $3 \mathrm{~cm}$., long.

\section{ACER L.}

\section{Sect. PLATANOIDEA Pax.}

Acer pictum Thunberg, Fl. Jap. 162 (1784).

The typical form does not occur in China.

Acer pictum, var. parviflorum C. K. Schneider, Ill. Handb. Laubholzk. II. 225 (1907).

Acer mono Maximowicz in Bull. Phys. Math. Acad. Sci. St. Pétersbourg, XV. 126 (1857); in Mel. Biol. II. 416 (1857).

Acer laetum, $\gamma$ parviflorum Regel in Bull. Phys. Math. Acad. Sci. St. Pétersbourg, XV. 219 (1857); in Mél. Biol. II. 486 (1857).

Acer pictum, var. mono Pax in Bot.Jahrb. VII. 236 (1886); in Engler, Pflanzenreich, Heft 8 (IV. 163), 47 (1903). - Rehder in Sargent, Trees and Shrubs, I. 177 (1905).

Western Hupeh: Fang Hsien, woods, common, alt. 1200-2300 m., May and September 1907 (Nos. 310, I889?, I905, I915, I9I9, I92 I); Hsing-shan Hsien, woods, alt. 1500-1800 m., May 31, 1907 (No. 642); Wên-tsao-shan, Hsing-shan Hsien, alt. 1800-2400 m., May 1907 (Nos. 1897, I922); Chang-yang Hsien, woodlands, May, July, and September 1907 (Nos. I923, I926, 2049). Western Szech'uan: Ta-p'ao-shan, northeast of Tachien-lu, forests, alt. 2300- 
2800 m., July 3, 1908 (No. r935); southeast of Sungpan, woods, alt. 2400-2700 m., August 1910 (No. 4507).

Acer fulvescens Rehder, n. sp.

Arbor usque ad $20 \mathrm{~m}$. alta trunco ad $65 \mathrm{~cm}$. diam.; cortex trunci modice laevis, longitudinaliter leviter tantum fissus, cinereus v. flavidocinereus, lenticellis brunneis saepe in series horizontales confluentes dispositis instructus. Ramuli juniores glabri, annotini pallide brunnei v. griseo-brunnei v. grisei, lenticellis paucis instructi. Gemmae brunneae, perulis 4-6 exterioribus. Folia membranacea, graciliter petiolata, circuitu suborbicularia, basi rotundata v. subcordata, plerumque trilobata, interdum lobis duobus basalibus minutis additis, sinubus latissimis apertis, lobis brevibus late triangulari-ovatis, subito longe acuminatis, 5-9 $\mathrm{cm}$. longa et 5-10 $\mathrm{cm}$. lata, supra glabra et laete viridia, subtus pallidiora, minute reticulata, tomento villoso initio flavescente, demum fulvescente laxe obtecta; petioli glabri v. tantum apicem versus pubescentes, rarius toti puberuli, $2.5-6 \mathrm{~cm}$. longi. Corymbus pedicello glabro, 2-3 cm. longo insidens, laxus, multiflorus, pedicellis gracilibus glabris v. apicem versus puberulis v. interdum corymbus totus puberulus; flores desiderantur. Samara alis horizontalibus loculo compresso $8 \mathrm{~mm}$. longo incluso $3 \mathrm{~cm}$. longis, supra medium latissimis et circa $1 \mathrm{~cm}$. latis, juniora purpurascentia, demum pallide flavido-brunnea.

Western Szech'uan: Pan-lan-shan, west of Kuan Hsien, woods, alt. 2100-2700 m., September 1908 (No. Ioo4, type); Wa-shan, woods, alt. 1800-2300 m., October 1908 (No. II62); Mupin, woods, alt. 15002000 m., July 1908 (No. I907).

Acer fulvescens seems most nearly related to Acer pictum Thunberg, which has the branches covered with the same kind of bark, but differs in the glabrous generally five-lobed leaves and the shorter wings of the fruits. Acer longipes, which is very similar, is easily distinguished by the smooth greenish or purplish bark of the younger branches without lenticels, the perfectly glabrous corymbs and petioles and by the larger leaves, their pubescence being not yellowish or fulvous. Nos. 1162 and 1907 differ from the type in their puberulous inflorescence. No. 1907 has even the whole petioles and the young branchlets below the nodes puberulous.

Acer cappadocicum Gleditsch, in Schrift. Gesell. Naturf. Freunde Berlin, VI. 116, t. 2 (1785).

Acer monspessulanum, var. $\beta$ Linnaeus, Sp. 1056 (in part as to syn. Tournefort) (1753).

Acer laetum C. A. Meyer, Verz. Kauk. Pflanz. 206 (1831). - Pax in Engler, Pfanzenreich, Heft 8 (IV. 163), 48 (1902). - Rehder in Sargent, Trees and Shrubs, I. 177 (1905). 
Though Gleditsch's species is based only on a single leaf without flowers or fruits, the figure leaves no doubt that it is the same as A. laetum C. A. Meyer, and his name being about 45 years older must supersede that given by Meyer. Acer cappadocicum is based on a leaf collected by Gundelsheimer, who traveled with Tournefort in Asia Minor during the years 1700 to 1702 . The same species is mentioned by Tournefort (Coroll. 43) under the name Acer orientalis Hederae folio, but without any description or remark.

Acer cappadocicum, var. sinicum Rehder, n. var.

Acer laetum var. cultratum Pax in Engler, Pfanzenreich, Heft 8 (IV. 163), 48 (in part) (1902). - Rehder in Sargent, Trees and Shrubs, I. 178 (in part) (1905).

A typo differt foliis minoribus plerumque $6-9 \mathrm{~cm}$. longis quinquelobis basi subcordatis v. truncatis, fructibus minoribus alis loculo incluso $2.5-3 \mathrm{~cm}$. longis, floribus minoribus.

Western Hupeh: Hsing-shan Hsien, woods, alt. 1500-2100 m., May 11, 1907 (No. I884); Chang-lo Hsien, woods, alt. 1500 m., May 1907 (No. I925). Western Szech'uan: Ta-p'ao-shan, northeast of Tachien-lu, woods, alt. 2300 m., July 5, 1908 (No. I903); Wa-ssu country, Wên-chuan Hsien, woods, alt. 2100-2600 m., October (No. 1009).

To this variety I refer all Chinese specimens I have seen from Hupeh, Szech'uan, and Yunnan. It differs from var. indicum in its smaller leaves with narrower and longer lobes, purplish when unfolding and less densely bearded in the axils of the primary veins beneath and in the smaller flowers and fruits. In the shape and size of its leaves it much resembles $A$. pictum, var. parviflorum $\mathrm{C}$. K. Schneider, but is easily distinguished by the smooth greenish bark of the young branches. No. 1903 from Szech'uan differs from the typical form in its somewhat larger leaves, 7 to $11 \mathrm{~cm}$. long, and Henry's No. 10877 from Yunnan in its slightly hairy calyx and ciliate sepals.

Acer cappadocicum and particularly its variety sinicum is often confounded with Acer pictum, as the relative length of wing and nutlet, usually given as the chief distinguishing character, is very variable in both species. The best character by which to distinguish these two species seems to lie in the bark of the younger branches; this character has moreover the advantage that it is always recognizable even in winter. In Acer pictum the epidermis of the young branches ceases growing during the first summer, and the bark of the branches becomes corky and grayish white, ashy gray or light grayish brown and is marked with conspicuous lenticels and in the second year with slight longitudinal fissures, while in $A$. cappadocicum the branches remain covered by the growing epidermis for several years, and are therefore smooth, ranging from green or greenish to purple in color, marked with only few and small lenticels or are without lenticels. Other distinguishing characters are the generally truncate leaves, at least in the Chinese variety, in A. pictum they are subcordate, the more convex and smaller nutlets in A. cappadocicum and the wing contracted at the base, while in $A$. pictum the nutlets are much compressed, almost flat, and the wings are of nearly the same width through their whole length. The terminal winter-buds of $A$. pictum have 2 to 3 pairs of outer scales, those of A. cappadocicum 3 to 4 pairs. 
Acer cappadocicum, f. tricaudatum Rehder, n. comb.

Acer laetum, var. tricaudatum Rehder in Sargent, Trees and Shrubs, I. 178 (1905).

Western Hupeh: Fang Hsien, cliffs, alt. 1700 m., May 14, 1907 (No. 1892). Western Szech'uan: west of Tachien-lu, side of streams, alt. 2700-3000 m., October 1908 (No. I358).

In No. 1358 the wings of the fruit are scarcely twice as long as the nutlets and the fruits much resemble those of $A$. pictum Thunberg, but the bark shows the character of A. cappadocicum. Acer cappadocicum, f. tricaudatum is apparently only a form of the preceding variety and possibly the variation is not even constant. ${ }^{1}$

Acer amplum Rehder, n. sp.

Arbor 5-12 m. alta ramulis junioribus glabris viridibus v. purpureoviridibus laevibus lenticellis parvis paucis institutis epidermate per plures annos persistente. Gemmae subglobosae, pallide olivaceae, perulis circa 6 exterioribus obtusis glabris margine minute ciliato excepto, perulis interioribus accrescentibus extus pilis fulvis appressis vestitis. Folia chartacea, quinque-loba, latiora quam longa, basi

1 The change of the specific name makes necessary, besides those mentioned above, the following new combinations of varietal names:

Acer cappadocicum, f. horticola Rehder, n. comb.

Acer laetum, f. horticola Pax in Bot. Jahrb. VII. 238 (1886).

Acer laetum, f. rubrum Schwerin in Gartenfl. XLII. 459 (1893).

Acer cappadocicum, f. tricolor Rehder, n. comb.

Acer laetum, f. tricolor Schwerin in Gartenfl. XLII. 459 (1893).

Acer cappadocicum, var. indicum Rehder, n. comb.

Acer cultratum Wallich, Pl. As. Rar. II. 4 (1831).

Acer Lobelii, subsp. laetum, var. indicum Pax in Bot. Jahrb. VII. 237 (1886).

Acer laetum, var. indicum Schwerin, Gartenfl. XLII. 459 (1893).

Acer laetum, var. cultratum Pax in Engler, Pflanzenreich, Heft. 8 (IV. 163), 48 (1902).

Of the other published names two, Acer laetum, var. colchicum Pax and Acer laetum, f. viride Hesse represent the type and need therefore no new names, while the two following varieties must be referred to other species.

Acer laetum, var. tomentosulum Rehder is identical with Acer longipes Franchet. It was originally based on a flowering branch with undeveloped, only partly unfolded leaves, apparently quite different from those of $A$. longipes, of which I also had seen at that time only a few specimens. Additional material, however, recently received convinced me that it cannot be separated from $A$. longipes.

Acer laetum, var. Regelii Pax is identical with A. turkestanicum Pax in Engler, Pflanzenreich, Heft 8 (IV. 163), 48 (1902), as is shown by the collection of Turkestanian Maples of the St. Petersburg Herbarium, which was loaned to me through the kindness of Mr. Lipsky. The leaves are always pubescent beneath, though at maturity the pubescence is sometimes much reduced and hardly noticeable without a lens, which probably accounts for the fact that Pax placed the fruiting specimen under the glabrous A. laetum. 
truncata v. subcordata, $10-18 \mathrm{~cm}$. lata et 9-16 $\mathrm{cm}$. longa, lobis late ovatis brevibus, subito longe acuminatis, basalibus interdum minutis v. fere obsoletis, sinubus late apertis, supra glabra, obscure viridia, subtus laete viridia, glabra axillis barbatis exceptis, initio ut supra sparse glandulosa, interdum ad basin puberula, maturitate reticulata; petioli graciles, glabri v. apice tantum puberuli, 7-10 $\mathrm{cm}$. longi. Corymbus fere sessilis v. pedunculo vix $5 \mathrm{~mm}$. longo, amplus et laxus, 12-15 cm. diam., glaber, pedicellis gracilibus perianthio longioribus; flores $12 \mathrm{~mm}$. diam.; sepala oblonga, apice obtusa, glabra, $5 \mathrm{~mm}$. longa, viridi-alba; petala obovata v. oblongo-ovata, basi contracta, $6 \mathrm{~mm}$. longa et 3-4 mm. lata, alba; stamina petalis breviora; ovarium glandulosum; stylus $1.5 \mathrm{~mm}$. longus stigmatibus recurvis stylum aequantibus. Samara alis angulo obtuso v. recto divergentibus loculo leviter venoso $11 \mathrm{~mm}$. longo et $7 \mathrm{~mm}$. lato incluso $3.5-4.5$ $\mathrm{cm}$. longis et 12-15 mm. latis, medio latissimis, pallide brunneis.

Western Hupeh: Patung Hsien, woodlands, alt. 1500-1800 m., June and July 1907 (Nos. I906, r938); without locality, April and May 1900 (Veitch Exped. Nos. 287, 605).

Acer amplum is nearly related to A. cappadocicum Gleditsch, which differs chiefly in its smaller long-peduncled inflorescence and smaller leaves with narrower and longer lobes. It forms with $A$. catalpifolium and $A$. longipes a group of closely related species characterized by the sessile ample inflorescence.

Acer amplum, var. tientaiense Rehder, n. comb.

Acer longipes, var. tientaiense C. K. Schneider, Ill. Handb. Laubholzk. II. 224 (1907).

Folia plerumque trilobis interdum utrinque lobo basali minuto instructa, latiora quam longa, 7-16 $\mathrm{cm}$. lata et 6-14 $\mathrm{cm}$. longa, basi plerumque truncata, utrinque glabra, lobis oblongo-ovatis longe acuminatis, margine undulato. Samara alis loculo incluso $2.5-3.5 \mathrm{~cm}$. longis plerumque vix $1 \mathrm{~cm}$. latis. Ceterum ut in typo.

Chekiang: Tientai Mts., 1889, E. Faber (No. 202). Kiangsi: Kuling, near temple, alt. 1200 m., July 29, 1907 (No. I502).

This variety differs from the type chiefly in its smaller more often 3-lobed leaves with longer and narrower lobes and in the smaller fruits with narrower wings. The specimens from Kuling approach the type in the larger mostly 5-lobed leaves and the somewhat larger fruits.

Acer catalpifolium Rehder, n. sp.

Arbor $10-23 \mathrm{~m}$. alta; truncus ad $1.20 \mathrm{~m}$. diam., cortice pallido cinereo-flavido interdum decorticante et corticem interiorem cinnamomeum detegente obtectus; ramuli juniores glaberrimi sine len- 
ticellis $\mathrm{v}$. lenticellis perpaucis parvis instructi, virides $\mathrm{v}$ purpurascentes, vetustiores epidermate laevi per plures annos persistente instructi. Gemmae ovoideae, circa $8 \mathrm{~mm}$. longae, olivaceae, glaberrimae, perulis 6 v. 8 exterioribus, inferioribus fere semiorbicularibus, superioribus ovatis obtusiusculis. Folia ovata v. ovato-oblonga, longe acuminata, basi rotundata, indivisa et integra $\mathrm{v}$. infra medium utrinque lobo rotundato brevissimo instructa, 9-18 $\mathrm{cm}$. longa et $4.5-12 \mathrm{~cm}$. lata, rarissime foliis $3-5$-lobis fere tam latis quam longis, lobis late ovatis longe acuminatis instructis, basi truncatis v. subcordatis intermixtis, utrinque glabra et laete viridia, subtus reticulata et in axillis barbulata; petioli glabri, virides, $4-14 \mathrm{~cm}$. longi. Corymbus sessilis, multiflorus, laxus, usque ad $20 \mathrm{~cm}$. diam.; flores desiderantur. Fructus pallide flavido-brunnei; alae cum loculis complanatis elevato-striatis 4-5 $\mathrm{cm}$. longae et 10-13 $\mathrm{mm}$. latae, rectae, angulo obtuso divergentes.

Western Szech'uan: near Ya-chou Fu, side of streams, alt. 800900 m., October 1908 (No. I359, in part), alt. 450-600 m., October 1910 (No. 4208); west of Kuan Hsien, alt. 900 m., June 17, 1908 (No. 1359, in part), without locality, May 1904 (Veitch Exped. No. 3350).

Acer catalpifolium is nearly allied to A. amplum and to A. longipes, both of which are easily distinguished by their three- or five-lobed leaves. Acer longipes, which occasionally produces some undivided leaves, differs besides in the pubescent under side of the leaves. According to Wilson this species is a handsome tree of very distinct appearance with the foliage turning yellow in autumn.

Acer longipes Franchet apud Rehder in Sargent, Trees and Shrubs, I. 178 (1905).

Acer laetum, var. tomentosulum Rehder, $l$. c.

Western Hupeh: South Wushan, woods, alt. 1800 m., October 1907 (No. 434, in part); Fang Hsien, alt. 1600 m., May 21, 1907 (No. 434, in part); Chang-yang, alt. 1600 m., October 1907 (No. 434 in part; Hsing-shan Hsien, woods, not common, alt. 1800 m., May 10, 1907 (No. I909).

Additional material has shown that the leaves are sometimes five-lobed, and that apparently my $A$. laetum, var. tomentosulum, which was based on a flowering specimen with only half grown leaves, belongs to this species, so that now the pubescence of the foliage constitutes the chief character by which to distinguish A. longipes from A. cappadocicum and A. amplum.

\section{Sect. PALMATA}

Acer palmatum Thunberg, Fl. Jap. 162 (1784).

Kiangsi: Kuling, thickets, alt. 1200 m., July 28 and 31, 1907 (Nos. I504, I505). 
These specimens agree well with typical $A$. palmatum; the leaves are generally seven-lobed, about $6-8 \mathrm{~cm}$. in diameter with oblong-ovate, acuminate and doubly serrate lobes, quite glabrous beneath except tufts of hairs at the base of the primary veins, and slightly reticulate; the wings of the fruit measure with the nutlet 2-2.2 $\mathrm{cm}$. The Hupeh specimens referred by me previously (in Sargent, Trees and Shrubs, I. 179) to this species belong to the following species.

Acer robustum Pax in Engler, Pflanzenreich, Heft 8 (IV. 163), 79 (1902).

Western Hupeh: Hsing-shan Hsien, woods, alt. 1800 m., May, June and October 1907 (Nos. 339, 1890, 1932); Fang Hsien, side of streams, alt. 1500-1800 m., May 21, 27 and July 1907 (Nos. I899, I900, I9I3, I920); Chang-lo Hsien, woods, alt. 1200-1500 m., September 1907 (No. 2050); without locality (Veitch. Exped. Nos. 538, $540)$.

Acer robustum differs from A. palmatum chiefly in its larger fruits and the larger and broader sepals and petals; the sepals and young fruits are purple. The leaves when unfolding are thinly covered with long hairs, but soon become glabrous except the bearded axils of the veins; the inflorescence is also at first slightly hairy.

Acer ceriferum Rehder, n. sp.

Arbor $10 \mathrm{~m}$. alta trunco circuitu metrali; ramuli hornotini tomento villoso cinereo partim usque secundum annum persistenti vestiti, vetustiores olivacei v. brunnei, laeves, cereo albido-cinereo obtecti. Folia membranacea, quinque- v. septem-lobata, circuitu fere semiorbicularia, latiora quam longa, basi truncata v. subcordata, $5-8 \mathrm{~cm}$. lata et $4.5-6 \mathrm{~cm}$. longa, lobis ovato-oblongis, acuminatis, simpliciter et argute serrulatis, sinubus acutis mediam laminam attingentibus, supra laete viridia, subtus pallidiora et reticulata, utrinque ad venas primarias pubescentia subtus densius, in axillis venarum non barbata; petioli 2.5-4 cm. longi, floccoso-villosi. Flores desiderantur. Fructus (immaturi sed evidenter ad iustam magnitudinem perventi) 3-6 in corymbo parvo; pedunculus gracilis, $4 \mathrm{~cm}$. longus, laxe villosus; sepala diu persistentia, oblonga, intus villosa; loculi horizontaliter patentes, $6 \mathrm{~mm}$. longi et $4 \mathrm{~mm}$. lati, laxe villosi, alae leviter incurvae cum loculis $2 \mathrm{~cm}$. longae, supra medium $8 \mathrm{~mm}$. latae, in loculum attenuatae, non decurrentes.

Western Hupeh: Fang Hsien, ravines (only one tree seen), alt. 1500 m., June and July 1907 (No. 1934).

On account of its pubescence this species seems most nearly related to $A$. Sieboldianum Miquel, which is easily distinguished by its seven- to eleven-lobed leaves, the bearded axils of the under side, the stouter petioles, the decurrent wing of the fruit and the absence of the waxy covering of the branches. 


\section{Sect. SPICATA Pax.}

Acer Oliverianum Pax in Hooker's Icon. XIX. text to t. 1897 (1889). Western Hupeh: Fang Hsien, woods, alt. 1500 m., July 1907 (No: 1936). ${ }^{1}$

Acer Giraldii Pax in Engler, Pflanzenreich, Heft 8 (IV.163), 79 (1902).

Western Szech'uan: southeast of Sungpan, forests, alt. 2400 m., August 1910 (No. 4506). Shensi: G. Giraldi (No. 2115, 2136).

Closely related to $A$. caesium Wallich from which it differs chiefly in the broader, less acuminate lobes, the minute often obsolete basal lobes, the coarser and more remote serration and the strongly reticulate under side of the leaves. The size of the fruits seems to afford no distinguishing character, for I have before me Himalayan specimens with fruits about $4 \mathrm{~cm}$. long and Wilson's No. 4506 has fruits 5.5 cm. long. Wilson's No. 2707 (in Herb. Kew.) from Hupeh referred by me formerly to $A$. caesium, probably belongs here.

Acer sinense Pax in Hooker's Icon. XIX. text to t. 1897 (1889).

Western Hupeh: Hsing-shan Hsien, woods, alt. 1500-2100 m. (No. I885).

Wilson's No. 1885, consisting only of sterile branches, is possibly a juvenile form of $A$. sinense; it differs from the typical form in its deeply divided five-lobed leaves with oblong, rather narrow lobes, the middle one 7-8 $\mathrm{cm}$. long and $3 \mathrm{~cm}$. broad. Apparently the same form is figured by Veitch as A. spec. (in Jour. Roy. Hort. Soc. XXIX. 354, fig. 99, 103). I have not been able to find among Wilson's and Henry's flowering and fruiting material a specimen which matches this form in the shape of the leaves.

Acer Wilsonii Rehder in Sargent, Trees and Shrubs, I. 157, t. 79 (1905).

Western Hupeh: South Wushan, woods, alt. 1200-1800 m., September 1907 (No. 233).

Acer erianthum Schwerin in Mitt. Deutsch. Dendr. Ges. X. 59 (1901).

Western Hupeh: Fang Hsien, thickets, alt. 1800-2400 m., July 1907 (No. I93I), October 1910 (No. 4428); southeast of Sungpan, alt. 2500 m., August 1910 (No. 4508).

1 There may be added a note on a variety from Fokien.

Acer Oliverianum, var. serrulatum Rehder, n. comb.

Acer Wilsonii, var. serrulatum Dunn in Jour. Linn. Soc. XXXVIII. 358 (1908).

Fokien: April to June 1905, S. T.Dunn (Herb. Hongkong Bot. Gard. No. 2545).

Differs from the type in its smaller, three-lobed leaves with short ovate appressed serrulate lobes narrowed into a short obtusish acumen, glabrous on both sides, reticulate beneath, $2.5-4 \mathrm{~cm}$. long and $3.5-5.5 \mathrm{~cm}$. broad; corymb small and few-flowered. To A. Wilsonii Rehder it seems less closely related; that species differs from it widely in its paniculate inflorescence, and in the entire or nearly entire lobes of the thinner leaves. 
Acer flabellatum Rehder in Sargent, Trees and Shrubs, I. 161, t. 81 (1905).

Western Hupeh: Sheng-tung-chin, Fang Hsien, woods, alt. 2100 m., May 19, 1907 (No. 683, flowers); Chang-yang Hsien, alt. 1200-1800 m., June and October 1907 (Nos. I89r, I9I2); Hsing-shan Hsien, woods, alt. 1800 m., May 19 and June 4, 1907 (Nos. I902, I9II); Patung Hsien, woods, alt. 1500 m., July 1907 (No. I9ro). Western Szech'uan: Wa-ssu country, Wên-chuan Hsien, woods, alt. 1800-2100 m., July and September 1908 (No. I006), alt. 2700 m., October 1910 (No. 4IOI); Nin-tou-shan, west of Kuan Hsien, thickets, alt. 2100 m., June 20, 1908 (No. r908).

Acer caudatum Wallich, $P l$. As. Rar. II. 4, 28, t. 132 (1831).

The typical form does not occur in China.

Acer caudatum, var. multiserratum (Maximowicz) Rehder in Sargent, Trees and Shrubs, I. 163 (1905).

Western Hupeh: Fang Hsien, woods and thickets, common, alt. 2300-2700 m., June and September 1907 (Nos. 309, I928). Western Szech'uan: Mupin, woods, alt. 2100-2700 m., June and July 1908 (Nos. IIIo, in part, I930); southeast of Tachien-lu, woods, alt. 21002700 m., June and October 1908 (Nos. IIIo, 4335); Wa-shan, woods, alt. 2100-2700 m., June and October 1908 (No. Ir6r); southeast of Sungpan, woodlands, alt. 2400-2700 m., August 1910 (No. 45ro); Pan-lan-shan, west of Kuan Hsien, woods, alt. 2700-2900 m., October 1910 (No. 4I43).

Most of the Szech'uan specimens approach var. Prattii Rehder in the more or less pubescent petioles and branchlets.

Acer caudatum, var. Prattii Rehder in Sargent, Trees and Shrubs, I. 164 (1905).

Western Szech'uan: Mupin, woods, alt. 2700 m., October 1910 (No. 42II); Wa-ssu country, Wên-chuan Hsien, alt. 2400 m., November 1910 (No. 4103).

Acer tataricum Linnaeus, Spec. II. 1054 (1753).

Western Hupeh: Ichang, roadside thickets, alt. 300 m., May 3, 1907 (No. 1933). Chekiang: Ningpo, I. Macgregor.

Acer trifidum Hooker and Arnott, Bot. Voy. Beechey, 174 (not Thunberg) (1841).

Chekiang: Ningpo, I. Macgregor. 
Acer trifidum, var. ningpoense Hance in Jour. Bot. XI. 168 (1873).

Kiangsi: Kiukiang Plain (at one place only), alt. 100 m., August 2, 1907 (No. 1503).

\section{Sect. INTEGRIFOLIA Pax ${ }^{1}$}

Acer oblongum Wallich apud De Candolle, Prodr. I. 593 (1824).

Western Hupeh: Ichang, around temples, alt. 30-300 m., August and October 1907 (No. 257); Fang Hsien, around houses, alt. 600900 m., July 1907 (No. I929, in part); Chang-yang Hsien, roadsides, alt. 300-900 m. (No. r929, in part).

Acer oblongum, var. latialatum Pax in Engler, Pflanzenreich, Heft 8 (IV. 163), 31 (1903).

Western Hupeh: Hsing-shan Hsien, alt. 300-900 m., May and October 1907 (No. 376, in part); Ichang, alt. 30-900 m., May and September 1907 (No. 376, in part).

Acer laevigatum Wallich, Pl. As. Rar. II. 3, t. 104 (1831).

Western Hupeh: Chang-lo Hsien, alt. 300-900 m., July and September 1907 (No. I924). Western Szech'uan: near Ya-chou, alt. 600-900 m., May, June, and September 1908 (No. 979).

Acer Fargesii Franchet apud Rehder in Sargent, Trees and Shrubs, I. 180 (1905).

Western Hupeh: Chang-lo Hsien, thickets, alt. 900-1200 m., May 1907 (No. I937).

\section{Sect. MACRANTHA Pax, emend. ${ }^{2}$}

Acer Davidii Franchet in Nouv. Arch. Mus. Paris, sér. 2, VIII. 212 (1884).

1 To record an extension of range the following species of this section may be mentioned here:

Acer cordatum Pax in Hooker's Icon. XIX. text to t. 1897 (1889).

Fokien: April to June 1905, S. T. Dunn (Herb. Hongkong Bot. Gard. No. 2541).

2 The fact that certain forms of A. laxiflorum Pax and A. Maximowiczii Pax are so similar that the separation of these species becomes difficult, has made it apparent to me, that there are no characters by which to distinguish in the case of some of the species the section Indivisa from the section Macrantha. I refer therefore all species of the Indivisa Pax to the Macrantha, except $A$. stachyophyllum Hiern, which I have already, in 1905, transferred to the section Arguta, A. distylum Siebold \& Zuccarini, which with its paniculate inflorescence seems to find its best place in 
Kiangsi: Kuling, thickets, alt. 1200 m., July 29, 1907 (No. r5or). Western Hupeh: Hsing-shan Hsien, woods, alt. 1500-1800 m., May and October 1907 (Nos. 34I, 436, 225, in part); Fang Hsien, woods, alt. $1700 \mathrm{~m}$., October 1907 (No. 649); north and south of Ichang, woods, abundant, alt. 1200-2300 m., September and October 1907 (No. 225 in part); Patung Hsien, side of streams, alt. 1200-1800 m., May 1907 (No. 225, in part); Fang Hsien, woods, common, alt. 15002300 m., May 28, 29 and June 1907 (No. 225, in part); South Wushan, woods, alt. 1200-2100 m., June 1907 (No. 225, in part); Chang-yang Hsien, alt. 1800 m., May 1907 (No. 225, in part); Chang-lo Hsien, woods, alt. 1200-1500 m., May 1907 (No. 225, in part). Western Szech'uan: foot of Pan-lan-shan, west of Kuan Hsien, woods, alt. 2100 m., October 1908 (No. 1005); Mupin, woods, alt. 1200-1800 m., July and October 1908 (No. 1005); Wa-ssu country, Wên-chuan Hsien, side of streams, alt. 2100 m., July and October 1908 (Nos. 1008, 1008, I9r8, in part); southeast of Tachien-lu, woods, alt. 2100-2400 m., June, 1908 (No. I9I7, in part); Hung-ya Hsien, alt. 900 m., September 12, 1908 (No. 1917, in part); Chin-ting-shan, northeast of Tachien-lu, woods, common, alt. 2100-2700 m., May 1908 (No. 1918, in part).

Acer laxiflorum Pax in Engler, Pflanzenreich, Heft 8 (IV. 163), 36 (1905).

I Acer Pavolinii Pampanini in Nuov. Giorn. Bot. Ital. n. ser. XVII. 422 (1910).

Western Szech'uan: Wa-ssu country, Wên-chuan Hsien, woods, alt. 1800-2300 m., July 1908 (Nos. ro07, r309, in part); alt. 21002700 m., October 1910 (No. 4099); Mupin, woods, alt. 1500-2300 m., June, October and November 1908 (Nos. 1007 ${ }^{\mathrm{a}}$, 1069, I234); Washan, thickets, alt. 1800-2100 m., June and October 1908 (No. Ir54); southeast of Tachien-lu, woods, alt. 2400-2700 m., June 1908 (No. 1309, in part); Pan-lan-shan, west of Kuan Hsien, woods, alt. 21002400 m., June 1908 (No. 1309 in part); Pan-lan-shan, west of Kuan

the section Integrifolia, and A. carpinifolium Siebold \& Zuccarini which remains as the only species in the section Indivisa. This section is clearly distinguished from the Macrantha by the character of the bark and particularly by the winter-buds which have several pairs of outer imbricate scales, while the Macrantha have only two valvate outer scales; the foliage and the inflorescence of $A$.carpinifolium are also quite different from that of any species of the Macrantha. From the section Macrantha as understood by $\mathrm{Pax}$ in his monograph two species, $A$. parviflorum Franchet and $A$. erosum Pax, must be removed and transferred to the Spicata, the last named as a synonym to $A$. caudatum, var. multiserratum Rehder. In the conception as now here proposed the section Macrantha will form a group of closely related species very uniform in the characters of inflorescence, flower and fruit. 
Hsien, woods, alt. 2100-2400 m., June 1908 (No. I904); alt. 24002700 m., October 1910 (No. 4I42); southeast of Sungpan, woods, alt. 2400-2700 m., August and October 1910 (Nos. 4100, 4513).

I have seen no specimens of Acer Pavolinii Pampanini, but the description agrees well with $A$. laxiflorum; it is based on specimens collected by C. Silvestri near Siang-yang, which would extend the range of A. laxiflorum into northern Hupeh.

Acer laxiflorum, var. longilobum Rehder, n. var.

A typo differt foliis manifeste quinque-lobatis, lobis superioribus caudato-acuminatis acumine argute serrato, interdum brevibus et brevius acuminatis, basalibus parvis acutis, venis subtus et apice petioli tomento floccoso flavido densiore obtectis, floribus purpureis.

Western Szech'uan: Chiu-ting-shan, cliffs, alt. $2300 \mathrm{~m}$., May 23, 1908 (No. I927, type); Wa-ssu country, Wên-chuan Hsien, woods, alt. 2400-2700 m., October 1910 (No. 4Io8); Tu-ti-liang Mts., Lungan Fu, woods, alt. 2400-2700 m., August 1910 (No. 4509).

This variety differs markedly from the type in its five-lobed leaves, but occasionally, particularly near the ends of the shoots, leaves appear which are similar to those of the typical form. The variety presents also some resemblance to A.Maximowiczii Pax, but that species has the middle lobe much more elongated and narrower, the lateral lobes more spreading and also narrower, and the leaves are quite glabrous when unfolding except tufts of hairs in the axils of the veins.

Acer Maximowiczii Pax in Hooker's Icon. XIX, text to t. 1897 (1899).

A. urophyllum Maximowicz in Act. Hort. Petrop. XI. 105 (1890).

Western Hupeh: north and south of Ichang, woods, common, alt. 1200-2300 m., May and September 1907 (Nos. 355, in part, I9I4, in part); Hsing-shan Hsien, woods, alt. 1800-2000 m., May 1907 (Nos. 355, in part, I914, in part); Wên-tsao Mt., Hsing-shan Hsien, woods, alt. 1800-2000 m., May 27 and June 5, 1907 (No. 355, in part); Fang Hsien, woods, alt. 2000-2500 m., May and July 19, 1907 (Nos. 355, in part, I9I4, in part); alt. 1500-2400 m., October 1910 (No. 4427); South Wushan, woods, alt. 1200-1500 m., September 1907 (No. 229).

\section{Sect. ARGUTA Rehder}

Acer tetramerum Pax in Hooker's Icon. XIX. text to t. 1897 (1889).

Western Hupeh: north and south of Ichang, woods, abundant, alt. 1200-2100 m., May and September 1907 (No. 274, in part); Changlo Hsien, alt. 1500-1800 m., May 1907 (No. 274, in part); Fang Hsien, 
woods, abundant, alt. 1800-2100 m., May and September 1907 (No. 274, in part); Hsing-shan Hsien, woods, abundant, alt. 1500-2100 m., May 19 and October 1907 (Nos. 274, in part, 430); Kuan Pao, Changyang Hsien, woods, alt. 1200-1800 m., December 1907 (No. 683, in part, fruits); Patung Hsien, woods, alt. 1500-1800 m., May 1907 (No. 274, in part); South Wushan, woods, common, alt. 1200-1800 m., May 11, 1907 (No. 274, in part).

Part of No. 274 represents A. tetramerum, var. lobulatum Rehder (in Fedde Rep. Nov. Sp. I. 174 [1905]) which passes gradually into the type and is perhaps better considered only a slightly different form. This and the type are restricted to Hupeh. The specimens of Szech'uan differ in their leaves being generally ovate to ovate-oblong in outline, not or only very slightly lobed and usually 3-nerved at the base. In regard to other characters they show marked differences, and the following three varieties can be distinguished.

Acer tetramerum, var. betulifolium Rehder, n. var.

Acer betulifolium Maximowicz in Act. Hort. Petrop. XI. 108 (1890).

Western Szech'uan: Sungpan, woodlands, alt. 2400-2800 m., August 1910 (No. 45II); southeast of Sungpan, alt. 3000-3200 m., August 1910 (4512); Wa-ssu country, Wên-chuan Hsien, alt. 18002400 m., July and September 1908 (No. I90r); alt. 2100-2500 m., October 1910 (No. 4ro2). Kansu: banks of the river Lumbu, south of Mt. Chagolo, July 11, 1885, S. N. Potanin. Northern Shensi: G. Giraldi (Nos. 2118, 2119, 7137, in herb. Florence).

With the recent material collected by Wilson in northwestern Szech'uan at hand I have come to the conclusion, that $A$. betulifolium cannot be separated specifically from A. tetramerum. Sungpan is situated only about 80 miles southwest of the type locality and Wên-chuan Hsien about 100 miles south of Sungpan, so that apparently the variety betulifolium is restricted to the northwestern part of the range of the whole species. It is chiefly distinguished from the type by its ovate or oblong-ovate leaves, not or only very slightly lobulate, glabrous or glabrescent and usually three-nerved at the rounded or sometimes cuneate base and by the broader wings of the fruits.

Acer tetramerum, var. betulifolium f. latialatum Rehder, n. forma.

Recedit a varietate praecedente praecipue racemis elongatis ad 18 $\mathrm{cm}$. longis et alis latioribus leviter introrsum falcatis, ad $14 \mathrm{~mm}$. latis.

Western Szech'uan: southeast of Sungpan, woodlands, alt. 2400-3000 m., August 1910 (No. 4I04, in part).

A very striking plant in fruit with its long pendulous racemes and broad wings.

Acer tetramerum, var. elobulatum Rehder, n. var.

Acer tetrameram Rehder in Sargent, Trees and Shrubs I. 171, t. 85 (in part as to the Szech'uan specimens and fig. 7) (1905). 
A typo recedit foliis ovatis v. ovato-oblongis, $6-8 \mathrm{~cm}$. longis, manifeste caudatis, duplicato-serratis, nec $\mathrm{v}$. vix lobulatis, basi rotundatis v. interdum angustatis, plerumque trinerviis, supra fere glabris, subtus villosulis $\mathrm{v}$. ad venas densius, facie sparsius adpresse pubescentibus.

Western Szech'uan: Wa-shan, woods, alt. 2100 m., June 1908 (No. I895); southeast of Tachien-lu, woods, alt. 1800-2400 m., June 1908 (No. I898); Chiu-ting-shan, thickets, alt. 2000 m., May 23, 1908 (No. 1894); no locality, alt. 2400-2700 m., May 1904 (Veitch Exped. No. 3348); Nanto (Veitch Exped. No. 1233); no locality, A. Henry (No. 8799).

This variety is distributed from Wên-chuan southward, but does not extend into western Hupeh. The typical form differs from this variety chiefly in the smaller triangular-ovate leaves, more or less lobed and sparingly pubescent on both sides or, while young, rarely glabrescent. The variety approaches in its more extreme forms $A$. stachyophyllum Hiern, which differs chiefly in its leaves being densely villous beneath, in its larger fruits and in the often branched racemes.

Acer tetramerum, var. elobulatum, f. longeracemosum Rehder, n. forma.

Recedit a varietate praecedente racemis elongatis ad $18 \mathrm{~cm}$. longis, pedicellis ad $4 \mathrm{~cm}$. longis, alis cum loculo $3.5-4 \mathrm{~cm}$. longis, foliis plerumque majoribus, $7-11 \mathrm{~cm}$. longis, petiolis ad $8 \mathrm{~cm}$. longis.

Western Szech'uan: Nin-tou-shan, west of Kuan Hsien, thickets, alt. 1800-2400 m., June 20, 1908 (No. I896, type); Mupin, woods, alt. 2400 m., September 1910 (No. 4104, in part).

Differs strikingly in its very long and slender racemes from the typical var. elobulatum. From forma latialatum, which has racemes of about the same length, it differs in the pubescent leaves and in the narrower wings generally about $1 \mathrm{~cm}$. broad.

Acer tetramerum, var. tiliifolium Rehder, n. var.

A typo recedit praecipue foliis late ovatis, basi cordatis, 5-nerviis, grossius inaequaliter v. duplicater serratis, nec incisis, nec lobulatis. Folia 4.5-7.5 longa et 3-5.5 lata, supra glabra, subtus molliter pubescentia, petiolis $2-4 \mathrm{~cm}$. longis, glabris. Fructus alis angulo obtuso divergentibus, rectis, cum loculo $3.5-4 \mathrm{~cm}$. longis et 8-10 mm. latis.

Western Szech'uan: Wa-ssu country, Wên-chuan Hsien, woods, alt. 2700 m., October 1910 (No. 4107).

Closely related to the var. elobulatum, but easily distinguished by the broadly ovate leaves cordate and 5-nerved at the base; they resemble those of a smallleaved Linden. 


\section{Sect. LITHOCARPA Pax}

Acer Franchetii Pax in Hooker's Icon. XIX. text to t. 1897 (1889).

Western Hupeh: north and south of Ichang, abundant, alt. 1400-1800 m., October 1907 (No. 337, in part); Patung Hsien, woods, alt. 1200-1800 m., May and October 1907 (No. 337, in part); Changlo Hsien, alt. 1200-1800 m., May 1907 (No. 337, in part); Fang Hsien, woods, common, alt. 1500-1800 m., May, July and November 1907 (Nos. 337, in part, 1888); South Wushan, woods, alt. 1200-1800 m., May 1907 (No. 337, in part); Hsing-shan Hsien, woods, common, alt. 1500-1800 m., May, June and November 1907 (No. 337, in part). Western Szech'uan: Chiu-ting-shan, woods, alt. 1500 m., May 1908 (No. 337, in part).

\section{Sect. TRIFOLIATA Pax}

Acer Henryi Pax in Hooker's Icon. XIX. text to t. 1896 (1889).

Western Hupeh: Fang Hsien, woods, common, alt. 1500-1800 m., May and June 1907 (No. 424, in part); Chang-yang Hsien, alt. 12001800 m., May and June 1907 (No. 424, in part); Patung Hsien, alt. 1200-1800 m., May 1907 (No. 424, in part); north and south of Ichang, woods, abundant, alt. 1000-1800 m., May 1907 (No. 424, in part); Hsing-shan Hsien, woods, alt. 1700-1800 m., May 11 and November 1907 (Nos. 424, in part, 424 ${ }^{\mathrm{a}}$ ).

The form which has the leaflets always coarsely toothed has been distinguished as $A$. Henryi, var. serratum Pampanini in Nuov. Giorn. Bot. Ital. n. ser. XVII. 421 (1910).

Acer sutchuense Franchet in Jour. de Bot. VIII. 294 (1894).

Western Hupeh: Fang Hsien, woods, rare, alt. 1800-2100 m., May and June 1907 (Nos. I886, I887); southeast of Sungpan, woods, alt. 2400-2700 m., August 1910 (No. 1886, in part).

Acer griseum Pax in Engler, Pflanzenreich, Heft 8 (IV. 163), 30 (1902).

Acer nikoense, var. griseum Franchet in Jour. de Bot. VIII. 294 (1894).

Western Hupeh: Hsing-shan Hsien, woods, not common, alt. 1200-1700 m., May 14, October and November 1907 (No. 340).

The bark is dark cinnamon-brown, peeling off in thin flakes like that of Betula nigra, L. 
Acer nikoense Maximowicz in Bull. Acad. Sci. St. Pétersbourg, XII. 227; in Mél. Biol. VI. 370 (1867).

The typical form is known only from central Japan.

Acer nikoense, var. megalocarpum Rehder, $n$. var.

A typo recedit foliis subtus densius villosis, foliolis majoribus, medio saepe $12-16 \mathrm{~cm}$. longo et brevius petiolulato, fructibus majoribus, alis loculo incluso $5-5.5 \mathrm{~cm}$. longis et $15-17 \mathrm{~mm}$. latis, gemmis dense cinereo-pubescentibus.

Western Hupeh: north and south of Ichang, woods, rare, alt. 1200-1800 m., May 1907 (No. 638, in part); Hsing-shan Hsien, alt. 1500-1800 m., May and November 1907 (No. 638, in part); Ching-lo Hsien, alt. 1200-1800 m., May 1907 (No. 638, in part); Patung Hsien, alt. 1200-1800 m., May 1907 (No. 638 in part); no locality, May 1900 (Veitch Exped. No. 368).

The Japanese tree is smaller in every part and less pubescent than the Chinese variety. 


\section{VITACEAE.}

Determined by F. Gagnepain.

TETRASTIGMA Planch.

Tetrastigma serrulatum Planchon in De Candolle, Monogr. Phaner. V. 432 (1887).

Cissus serrulata Roxburgh, Fl. Ind. I. 432 (1820).

Vitis serrulata Wallich apud Miquel in Ann. Mus. Lugd.-Bat. I. 77 (1863).

Western Szech'uan: valley of Tung-nsi, east of Tachien-lu, on rocks, alt. 900-1200 m., August 1908 (No. 2739).

Tetrastigma obtectum Planchon in De Candolle, Monogr. Phaner. V. 434 (1887). - Gagnepain in Lecomte, Not. Syst. I. 323 (1911).

Tetrastigma obtectum, var. pilosum Gagnepain, l. c. 324 (1911).

Western Hupeh: Hsing-shan Hsien, on rocks, common, alt. 300900 m., June 8, 1907 (No. 2738). Western Szech'uan: Hung-yah Hsien, adhering to red sandstone rocks, abundant, alt. 600-900 m., September 6, 1908 (No. 878).

\section{CAYRATIA Juss.}

Cayratia tenuifolia Gagnepain in Lecomte, Not. Syst. I. 348 (1911).

Vitis tenuifolia Wight \& Arnott, Prodr. Fl. Ind. 129 (1834).

Cissus tenuifolia Heyne in Wallich, Cat., ex Planchon in De Candolle, Monogr. Phaner. V. 563 (1887).

Kiangsi: Kuling, thickets, abundant, alt. 1200 m., July 29, 1907 (No. 1705).

Cayratia oligocarpa Gagnepain, l. c. 359 (1911).

Western Hupeh: Fang Hsien, thickets, road sides, etc., alt. 300900 m., August 1907 (No. 2737); Hsing-shan Hsien, cliffs, etc., alt. 300-900 m., June and October 1907 (No. 342), ravines, alt. 300-900 m., June 1907 (No. 35).

The determination of No. 35 is somewhat doubtful on account of the absence of fruits; it is possibly a form of $C$. tenuifolia Gagnepain. 


\section{AMPELOPSIS Planch.}

Ampelopsis aconitifolia Bunge, in Mém. Sav. Etr. Acad. Sci. St. Pétersb., II. 86; (Enum. Pl. Chin. Bor. 12) (1833). - Planchon in De Candolle, Monogr. Phaner. V. 450 (1887).

Vitis aconitifolia Hance in Jour. Linn. Soc. XIII. 77 (1873).

Western Hupeh: Hsing-shan Hsien, thickets, common, alt. 6001200 m., June 6, 1907 (No. 2735).

Ampelopsis heterophylla Siebold \& Zuccarini, var. amurensis Planchon, l. c. 456 (1887).

Western Szech'uan: Was-su country, Wên-chuan Hsien, thickets, alt. 1500 m., June and September 1908 (No. 2719). Western Hupeh: Chang-yang Hsien, thickets, alt. 900-1200 m., June and September 1907 (No. I57), alt. 600-1000 m., May and September 1907 (No. 2718), Hsing-shan Hsien, thickets, alt. 900-1200 m., May and August 1907 (No. 159), alt. 900-1500 m., June 6 and 8, 1907 (Nos. 2722, 2723); Chang-lo Hsien, thickets, alt. 900-1200 m., June and September 1907 (No. I2I), woodlands, June 1907 (No. 272I); Fang Hsien, thickets, alt. 900-1200 m., July 1907 (No. 2724). Kiangsi: Kuling, thickets, abundant, alt. 1200 m., July 28, 1907 (No. I703).

Ampelopsis heterophylla, var. Delavayana Gagnepain, n. comb.

Ampelopsis Delavayana Planchon in De Candolle, Monogr. Phaner. V. 458 (1887).

Western Hupeh: Patung Hsien, alt. 900-1000 m., October 1907 (No. 4I9); Ichang, thickets, alt. 300-900 m., June and November (No. 604); Chang-lo Hsien, thickets, alt. 600-900 m., June and September (No. I24); Changyang Hsien, thickets, 600-900 m., June and September 1907 (No. I30).

Foliage variable; Nos. 130 and 604 represent the form with the leaves trifoliolate, while Nos. 124 and 419 have the leaves simple like the var. amurensis and only occasionally divided into three leaflets.

Ampelopsis heterophylla, var. Gentiliana Gagnepain, n. comb.

Vitis Gentiliana Léveillé \& Vaniot in Bull. Soc. Agric. Sci. Sarthe, LX. 38 (1905).

Western Hupeh: Chang-lo Hsien, cliffs, alt. 600-900 m., June 1907 (No. 2734).

The leaves have either three leaflets with the lateral leaflets lobed or five leaflets with coarse and remote teeth. 
Ampelopsis heterophylla, var. cinerea Gagnepain, n. var.

Folia 3-5 lobata sinubus obtusis v. rotundatis, utrinque dense cinereo-pubescentia.

Western Hupeh: Chang-lo Hsien, side of streams, rocks, etc., alt. 900 m., June 1907 (No. 2720); Ichang, roadsides, alt. 300-900 m., June 1907 (No. 2736).

Ampelopsis megalophylla Diels \& Gilg in Bot. Jahrb. XXIX. 466 (1900).

Western Hupeh: north and south of Ichang, woods, alt. 12001500 m., June and September 1907 (No. I43).

\section{PARTHENOCISSUS Planch.}

Parthenocissus Henryana Diels \& Gilg in Bot. Jahrb. XXIX. 464 (1900).

Vitis Henryana Hemsley in Jour. Linn. Soc. XXIII., 132 (1886).

Psedera Henryana C. K. Schneider, Ill. Handb. Laubholzk. II. 318 (1909).

Western Hupeh: South Wushan, cliffs, alt. 600-900 m., August and December 1907 (No. 440). Ichang, glens, June 6 and October 1907 (No. 454).

Parthenocissus Thomsonii Planchon in De Candolle, Monogr. Phaner. V. 453 (1887).

Vitis Thomsonii Lawson in Hooker f., Fl. Brit. Ind. I. 657 (1875).

Parthenocissus Henryana, var. glaucescens Diels \& Gilg in Bot. Jahrb. XXIX. 464 (1900).

Western Hupeh: north and south of Ichang, cliffs, alt. 600-1200 m., June and September 1907 (No. 235); Chang-yang Hsien, alt. 9001500 m., November 1907 (No. 752).

Parthenocissus himalayana Planchon in De Candolle, Monogr. Phaner. V. 450 (1887).

Ampelopsis himalayana Royle, Ill. Bot. Himal. I. 149 (1839).

Vitis himalayana Lawson in Hooker f., Fl. Brit. Ind. I. 655 (1875).

Psedera himalayana C. K. Schneider, Ill. Handb. Laubholzk. II. 313 (1909)

The typical form has been reported from western China, but is not represented in the Wilson collection.

Parthenocissus himalayana, var. rubrifolia Gagnepain, n. comb.

Vitis rubrifolia Léveillé \& Vaniot in Bull. Soc. Agric. Sci. Sarthe, LX. 44 (1905)

?Parthenocissus sinensis Diels \& Gilg in Bot. Jahrb. XXIX. 463 (1900). 
Western Szech'uan: Wa-shan, clinging to rocks, alt. 1200-1500 m., October 1907 (No. Irog); South Wushan, adhering to rocks, alt. 900 m., September 1907 (No. 205).

Parthenocissus Landuk Gagnepain, n. comb.

Ampelopsis heterophylla Blume, Bijdr. Fl. Ned. Ind. 194 (not Siebold \& Zuccarini) (1825).

Cissus Landuk Hasskarl in Flora, XXV. Beibl. II. 39 (1842).

Vitis Landuk Miquel in Ann. Mus. Lugd.-Bat. I. 90 (1863).

Landukia Landuk Planchon in De Candolle, Monogr. Phaner. V. 446 (1887).

Western Hupeh: north and south of Ichang, cliffs, common, alt. 300-900 m., June 1907 (No. 273r). Kiangsi: Kuling, adnate to rocks, common, alt. 1200 m., July 31, 1907 (No. r696 bis). Western Szech'uan: Ta-p'ao-shan, northeast of Tachien-lu, climbing over rocks, alt. 2100-2400 m., July 1908 (No. 2730).

The determination of No. 2730 is only provisional. There is but little difference between this species which has the leaves on the flowering branchlets always 3 -foliolate and the following with the leaves on the flowering branchlets 3-lobed. Without fruits I had to distinguish these two species by this character alone.

Parthenocissus tricuspidata Planchon in De Candolle, Monogr. Phaner. V. 452 (1887).

Ampelopsis tricuspidata Siebold \& Zuccarini in Abhand. Alkad. Münch. IV. pt. II. 196 (1845).

Vitis inconstans Miquel in Ann. Mus. Lugd.-Bat. I. 31 (1863).

Quinaria tricuspidata Koehne, Deutsche Dendr. 398 (1893).

Psedera tricuspidata Rehder in Rhodora, X. 29 (1908).

Kiangsi: Kuling, common, adhering to rocks, alt. $1200 \mathrm{~m}$., July 1907 (No. I696); Kuling, near temple, rare, climbing on rocks and trees, alt. 1200 m., July 1907 (No. r706). Western Hupeh: south of Ichang, ravines, alt. 900-1200 m., October 1907 (No. 464).

\section{VITIS L., Planch. emend.}

Vitis flexuosa Thunberg in Trans. Linn. Soc. XI. 103 (1793). Planchon in De Candolle, Monogr. Phaner. V. 347 (1887).

Vitis truncata Blume, Bijdr. Fl. Ned. Ind. 195 (1825).

Western Hupeh: Hsing-shan Hsien, thickets, alt. 600-1200 m., June and August 1907 (No. I70), alt. 900-2100 m., July 1907 (No. 2714); north and south of Ichang, common, cliffs, alt. 600-1200 m., June 1907 (No. 2725). 
Vitis flexuosa, var. parvifolia Gagnepain, n. var.

Vitis parvifolia Roxburgh, Fl. Ind. I. 662 (1832).

Vitis flexuosa, var. Wilsonii Veitch, Novelties for 1908-9, 26 (without sufficient description) (1908).

Western Hupeh: Patung Hsien, rocky places, alt. 600-900 m., May 1907 (No. 2727); Chang-lo Hsien, rocky places, alt. 600-1200 m., May 1907 (No. 2726).

Vitis pentagona Diels \& Gilg in Bot. Jahrb. XXIX. 460 (1900).

Kiangsi: Kuling, thickets, common, alt. 300-600 m., August 1, 1907 (No. I699). Western Hupeh: north and south of Ichang, thickets, common, alt. 300-1200 m., May and September 1907 (No. 134); Chang-lo Hsien, over rocks, alt. 600-900 m., July 1907 (No. 77). Western Szech'uan: Tachien-lu, alt. 1200-1800 m., December 1908 (No. 1046).

No. 77 represents a small dwarfed form, resembling $V$. flexuosa, var. parvifolia, but the lower surface of the leaves is tomentose.

Vitis reticulata Gagnepain in Lecomte, Not. Syst. No. 12 (1911).

Western Hupeh: Hsing-shan Hsien, alt. 900-1800 m., June and September 1907 (No. 250); cliffs, alt. 900-1500 m., June and October 1907 (No. 378).

Vitis Piasezkii Maximowicz in Bull. Acad. Sci. St. Pétersb. XXVII. 461 (1882); in Mél. Biol. XI. 207.

Vitis Pagnuccii Romanet du Caillaud in Congr. Geog. Toulouse, 1884; in Jour. de la Vigne 1887, p. 283. - Planchon in De Candolle, Monogr. Phaner. V. 364 (1887).

Western Hupeh: north and south of Ichang, thickets, alt. 600-1500 m., May and September 1907 (Nos. 215, 126ª 248, 2717).

No. 2717 is remarkable for its polymorphic foliage showing on the same branch the trifoliolate leaves of $V$. Piasezkii and the undivided leaves of $V$. betulifolia..

Vitis betulifolia Diels \& Gilg in Bot. Jahrb. XXIX. 461 (1900).

Western Szech'uan: Wa-ssu country, Wên-chuan Hsien, alt. 1200-1800 m., July and September 1908 (No. I046); near Ta-chien-lu, alt. 1200-1800 m., October 1908 (No. I307); Wa-shan, thickets, alt. 1500-2100 m., June 1908 (No. 27I3). Western Hupeh: Fang Hsien, thickets, alt. 1200-1800 m., September 1907 (No. 283); Chang-lo Hsien, alt. 900-1500 m., September 1907 (No. I5o); Hsing-shan Hsien, thickets, alt. 900-2100 m., June and September 1907 (Nos. 242, 246, 2715, 2716); Patung Hsien, alt. 900-1500 m., September 1907 (No. 126); Fang Hsien sit. 1600 m., September 1907 (No. 286). 
The specimens agree well with the description given by Diels and Gilg, but I have not seen the type of the species. It seems to be only a form of V. Piasezkii Maximowicz with undivided or simply lobulate leaves.

Vitis armata Diels \& Gilg in Bot. Jahrb. XXIX. 462 (1900). ${ }^{1}$

Spinovitis Davidii Romanet du Caillaud in Compt. Rend. Acad. Paris, XCII. 1096 (nom. nudum) (1881) - Carrière in Rev. Hort. 1881, 239; 1885, 55, 10; 1891, 102, 24-26. - Planchon in De Candolle, Monogr. Phaner. V. 365 (quasi synon.) (1887).

Vitis Davidii Foëx, Cour. Vit. 44 (1886). - Mouillefert, Traitê Art. Arbriss. II. 803 (1895). - Viala, Ampelogr. I. 437, t. 35 (1910).

Kiangsi: Kuling, thickets, abundant, alt. 1200 m., June 1907 (No. I695); cultivated in plain, Kinkiang, alt. 100 m., June 1907 (No. 1695).

Vitis armata, var. cyanocarpa Gagnepain, n. var.

A typo recedit aculeis rarioribus, interdum fere nullis in ramis hornotinis. An planta hybrida inter $V$. armatam et $V$. betulifoliam?

Western Hupeh: north and south of Ichang, thickets, alt. 6001500 m., June and October 1907 (No. 409); Fang Hsien, thickets, alt. 1500 m., September 1907 (No. 29r), alt. 900-1500 m., July 1907 (No. 2732); Hsing-shan Hsien, alt. 1200-1500 m., June and September 1907 (No. 603).

What is possibly the same form has been distributed by Veitch under the name Vitis armata, var. Veitchii, mentioned without sufficient description in his Novelties for $1908-9,26 \mathrm{f}$.

Vitis Thunbergii Siebold \& Zuccarini in Abhand. Akad. Münch. IV. pt. ii. 198; (Fl. Jap. Fam. Nat. 90) (1845). - Planchon in De Candolle, Monogr. Phaner. V. 333 (1887).

Vitis bryoniaefolia Hance in Jour. Bot. XX., 3 (not Bunge) (1882)

Vitis ficifolia Bunge in Mém. Sav. Etr. Acad. Sci. St. Pétersb. II. 86 (Enum. Pl. Chin. Bor. 12) (1833).

1 Les descriptions de Romanet du Caillaud et Carrière concernant le Spinovitis Davidii ou Vitis Davidii sont très insuffisantes au point de vue des caractères. De plus ces auteurs ont hésité entre deux genres Spinovitis et Vitis, ce dernier cité indecidemment. Au contraire Diels et Gilg ont donné une description qui n'admet aucune equivoque. C'est la raison pour laquelle j'ai préféré aux autres plus anciennes, la combinaison plus recente Vitis armata Diels \& Gilg.

F. Gagnepain.

The descriptions of this plant by Foëx and by Mouillefert leave no possible doubt of its identity and we cannot therefore accept the name proposed by Diels $\&$ Gilg and now by Monsieur Gagnepain.

The name therefore of his variety becomes Vitis Davidii, var. cyanocarpa, n. comb.

C. S. S. 
Vitis Thunbergii, var. cinerea Gagnepain, n. var.

A typo recedit statura minore, foliis parvis subtus cinereo-puberulis. Western Hupeh: Hsing-shan Hsien, common, climbing or prostrate over rocks, alt. 600-1200 m., June 1907 (No. 2728).

Allied to the following variety.

Vitis Thunbergii, var. adstricta, Gagnepain, n. var.

Vitis adstricta Hance in Jour. Bot. XX. 258 (1882).

Western Hupeh: Ichang, glens, etc., climbing or prostrate over rocks, alt. 300-600 m., May 1907 (No. 2729).

Vitis Romanetii Romanet du Caillaud in Compt. Rend. Acad. Paris, XCII. 1096 (nom. nudum) (1881). - Planchon in De Candolle, Monogr. Phaner. V. 365 (1887).

Vitis rutilans Carrière in Rev. Hort. 1890, 444, t.

Western Hupeh: north and south of Ichang, thickets, alt. 9001200 m., May 1907 (No. 2733). 


\section{CAPRIFOLIACEAE.}

Determined by ALFRED REHDER.

\section{SAMBUCUS L.}

Sambucus javanica Reinwardt ex Blume, Bijdr. Fl. Ned. Ind. 657 (1825). - Schwerin in Mitt. Deutsch. Dendr. Ges. XVIII. 50 (1909).

Western Hupeh: Patung Hsien, thickets, alt. 900-1200 m., August 1907 (No. 2520).

Sambucus Sieboldiana Blume apud Graebner in Bot. Jahrb. XXIX. 584 (1901). - Schwerin in Mitt. Deutsch. Dendr. Ges. XVIII. 50 (1909).

Sambucus racemosa, var. Sieboldiana Miquel in Ann. Mus. Lugd.-Bat.II. 265 (1866).

Sambucus Sieboldiana Blume ex Miquel, l. c. (quasi synon. praeced.)

Western Hupeh: north and south of Ichang, thickets, alt. 300900 m. (No. 2528); Fang Hsien, abundant, alt. 1500-2400 m., June 16, 1910 (No. 4490). Szech'uan: Sungpan, alt. 2100-2400 m., August 1910 (Nos. 4020, 4043). South Wushan, A. Henry (Nos. 5532, 5533).

Sambucus Williamsii Hance, quoted as a synonym of this species by Count von Schwerin, belongs to $S$. racemosa, as Hance's original specimens show; otherwise Hance's name would have precedence, because the mentioning by Miquel of the name S. Sieboldiana Blume as a synonym does not constitute publication.

\section{VIBURNUM L.}

Sect. THYRSOSMA Rehd.

Viburnum Henryi Hemsley in Jour. Linn. Soc. XXIII. 353 (1888). Rehder in Sargent, Trees and Shrubs, II. 35, t. 116 (1907).

Western Hupeh: Fang Hsien, upland thickets, alt. 1500-2100 m., June and September 1907 (No. 270); Hsing-shan Hsien, woodlands, alt. 1800 m., July 1907 (No. I829). Western Szech'uan: northeast of Sungpan, thickets, alt. 2400-2700 m., August 1910 (No. 4499).

Viburnum Henryi $\times$ erubescens.

Western Hupeh: Fang Hsien, uplands, rare, alt. 2400 m., May 106 
27 and August 1907 (No. I815); Fang Hsien, uplands, June 1907 (No. I8I4, as to the flowers).

Wilson's Nos. 1814 and 1815 appear to be intermediate between $V$. Henryi and $V$. erubescens, and this together with the fact that these two species grow in the same locality where the specimens in question were collected seems to point toward a hybrid origin of these plants. The corolla is infundibuliform, but short, the tube being but little longer than the limb, while in $V$. Henryi it is shorter, and in $V$. erubescens about twice as long as the limb. The inflorescence is more like that of the typical $V$. erubescens. The leaves are membranaceous like those of $V$. erubescens, but are remotely serrulate or denticulate as in $V$. Henryi, which differs in its subcoriaceous generally narrower leaves, while the first named species is distinguished by its crenately serrate generally broader leaves.

Viburnum erubescens Wallich, Plant. As. Rar. II. 29, t. 134 (1830).

The Chinese specimens of $V$. erubescens differ in several respects from the Nepal forms as described by Wallich, and may be here treated as varieties as follows:

Viburnum erubescens, var. Prattii, n. var.

Viburnum Prattii Graebner in Bot. Jahrb. XXIX. 584 (1901).

Western Szech'uan: Tachien-lu, upland, alt. 2700 m., July and September 1908 (No. I827); Wa-ssu country, Wên-chuan Hsien, thickets, alt. 1800-2100 m., June and September 1908 (No. 805); Nin-tou-shan, west of Kuan Hsien, alt. 2250 m., June 20, 1908 (No. 1824); Wa-shan, thickets, rare, alt. 2400 m., July 1908 (No. r825); Mupin, thickets, common, alt. 2100-2500 m., June 1908 (No. I826); northeast of Sungpan, woodlands, alt. 2100-2700 m., August 1910 (No. 403i).

This variety differs from the type chiefly in its broader and larger, broadly obovate or elliptic or rarely oblong-obovate leaves pubescent beneath, with the pubescence persistent at least on the veins, and in its violet-purple anthers which are yellow in the type. I have not seen the type specimen of Graebner's V. Prattii from Tachien-lu, but his description agrees perfectly with Wilson's No. 1827 from the same locality, and with the other specimen quoted here, as well as with Giraldi's specimens cited by Graebner which I have seen.

Viburnum erubescens, var. gracilipes Rehder, n. var.

A typo recedit praecipue foliis latioribus plerumque ovalibus basi rotundatis, inflorescentiis glabris laxioribus, elongatis, 7-12 $\mathrm{cm}$. longis, floribus partim graciliter pedicellatis, tubo corollae sensim ampliato, calyce cupuliformi, fructibus angustioribus.

Western Hupeh: Fang Hsien, thickets, common, alt. 1700-2400 m., June and September 1907 (No. 305, type); Fang Hsien, uplands, September 1907 (No. I814, in part, fruit); Hsing-shan Hsien, woodlands, alt. 1800-2700 m., June and October 1907 (No. I828); no lo- 
cality (Veitch Exped. No. 1382); no locality, A. Henry (No. 6543). Eastern Szech'uan: South Wushan, A. Henry (No. 5691).

From the Szech'uan form this variety differs chiefly in its glabrescent leaves, the slender and loose inflorescence with part of the flowers on slender pedicels, the saucer-shaped calyx with very broad, often obsolete, teeth, the yellow anthers and the narrower fruits. Some specimens, however, as Nos. 1814 and 1824, approach in their narrower and more pubescent leaves the Szech'uan form, but they have yellow anthers, while some Szech'uan plants have a saucer-shaped calyx like var. gracilipes. ${ }^{1}$

Viburnum brachybotryum Hemsley in Jour. Linn. Soc. XXIII. 349 (1888).

Western Hupeh: ravines around Ichang, alt. 30-300 m., March 20 and July 1907 (No. I840).

Wilson's flowering specimen bears on its label the note "flowers white functionally dioecious" and consists of two branches apparently from different plants and showing two kinds of flowers. One of the branches bears a terminal many-flowered panicle with the peduncle $6.5 \mathrm{~cm}$. long; the corolla does not seem to be fully developed, the lobes are upright and slightly incurved, not spreading, the rudimentary stamens are about $1 \mathrm{~mm}$. long with deformed dark colored and empty anthers, and the short thick style bears a large capitate three-lobed stigma. The other branch bears two small panicles, 1.5 and $2.5 \mathrm{~cm}$. long, in the axils of the leaves of the preceding year; the corolla is rotate, about $6 \mathrm{~mm}$. in diameter, with spreading lobes; the stamens are $4 \mathrm{~mm}$. long and exceed somewhat the corolla-lobes, with yellow oval pollen-bearing anthers; the style is reduced to its conical base with three minute blunt points at the apex; the ovary is smaller and apparently sterile. As I have seen no other flowering specimen of the species I do not know whether dioecious flowers are the rule or whether this is only an abnormal case. No other species in the genus Viburnum is known to have diclinous or incompletely diclinous flowers.

Viburnum oliganthum Batalin in Act. Hort. Petrop. XIII. 372 (1894).

Western Szech'uan: Wa-ssu country, Wên-chuan Hsien, thickets, alt. 1500-1800 m., July and October 1908 (No. I03I); Mupin, thickets, alt. 1200-2250 m., May and August 1908 (No. 805).

1 In connection with these varieties another very distinct variety of $V$. erubescens from Upper Burma may be described here:

Viburnum erubescens, var. burmanicum Rehder, n. var.

Folia chartacea, glabra, oblonga, basi rotundata, apice subito in acumen longum falcatum producta, remote denticulata, $10-12 \mathrm{~cm}$. longa et $4.5-5.5 \mathrm{~cm}$. lata, supra obscure viridia, subtus pallidiora, utrinsecus 6-costata costis curvatis anastomosantibus trabiculis parallelis conspicuis conjunctis. Panicula glabra, longe pedunculata, late pyramidalis, 6-8 $\mathrm{cm}$. diam. et 4-6 cm. longa; corolla infundibuliformis limbo patulo, antheris flavis semiexsertis.

Upper Burma: Kachin Hills, 1898. Shaik Mokim (Ex. Herb. Hort. Calcutt. in Herb. Arnold Arboretum).

This very distinct form is easily recognized by its chartaceous perfectly oblong and quite glabrous remotely denticulate leaves and by the very broad and short inflorescence. 
The panicles in Wilson's specimens have usually from 10 to 20 flowers, while Batalin describes them as 7-flowered, but there seems to be no other difference between the Kansu and Szech'uan specimens.

\section{Sect. PSEUDOTINUS Clarke}

Viburnum cordifolium Wallich ex De Candolle, Prodr. IV. 327 (1830). - Rehder in Sargent, Trees and Shrubs, II. 81, t. 138 (1908).

Western Szech'uan: Wa-shan, forests and thickets, common; Mupin, forests, and Nin-tou-shan, west of Kuan Hsien, woods, alt. 2250-2700 m., June and September 1908 (No. 9I8); Wên-chuan Hsien, forests, alt. 2400-2700 m., October 1910 (No. 4I2I); Tachienlu, woodlands, alt. 2100-2500 m., October 1910 (No. 4I2I).

Viburnum sympodiale Graebner in Bot. Jahrb. XXIX. 587 (1901). Rehder in Sargent, Trees and Shrubs, II. 83, t. 139 (1908).

Kiangsi: Kuling, thickets, rare, alt. 1300 m., July 31, 1907 (No. I708); Western Hupeh: Chang-yang Hsien, woods north and south of Ichang, alt. 1800 m., May and August 1907 (No. 294); Hsing-shan Hsien, woods, alt. 1800 m., August 1907 (No. 294ª).

\section{Sect. LANTANA De Candolle}

Viburnum Veitchii C. H. Wright in Gard. Chron. ser. 3, XXXIII. 257 (1903).

Western Hupeh: Fang Hsien, thickets, alt. 1800-2400 m., May 28, 1907 (No. I288'); alt. 2100-2700 m., October 6, 1910 (No. 4498). Western Szech'uan: Pan-lan-shan, west of Kuan Hsien, thickets, alt. 2100-2700 m., June 1908 (Nos. I288, in part, 4030); around Tachien-lu, thickets, alt. 2700 m., October 1908 (No. I288, in part); around Tachien-lu, upland thickets, alt. 2700-3000 m., October 1910 (No. 409I); Sungpan, thickets, alt. 1800-2400 m., August 1910 (No. 4030).

The specimens from Fang Hsien and from Pan-lan-shan differ from the type in the thinner yellowish pubescence of the under side of the leaves.

Viburnum buddleifolium C.H Wright in Gard. Chron. ser. 3, XXXIII. 257 (1903).

Western Hupeh: Hsing-shan Hsien, thickets, not common, alt. 900 m., May and July 1907 (No. 1838).

Viburnum shensianum Maximowicz in Bull. Acad. Sci. St. Pétersbourg, XXVI. 480 (1880). - Rehder in Sargent, Trees and Shrubs, II. 85 , t. 140 (1908). 
Western Hupeh: Hsing-shan Hsien, side of streams, rare, alt. 900 m., May 25, 1907 (No. 1839).

Viburnum macrocephalum Fortune in Jour. Hort. Soc. Lond. II. 244 (sensu Maximowicz in Bull. Soc. Nat. Mosc., liv. 24 [1879]) (1847).

Western Hupeh: Chang-lo Hsien, thickets, not common, alt. 1350 m., May 1907 (No. I834); Chang-yang Hsien, alt. 1200-1500 m., May 1907 (No. 1835).

Viburnum hypoleucum Rehder in Sargent, Trees and Shrubs, II. 111 (1908); in Fedde, Rep. Sp. Nov. IX. 179 (1911).

Western Szech'uan: Yangtze banks, Wan Hsien, thickets, common, alt. 100-300 m., April 1908 (No. I836).

Viburnum utile Hemsley in Jour. Linn. Soc. XXIII. 356 (1888). Rehder in Sargent, Trees and Shrubs, II. 89, t. 142 (1908).

Western Hupeh: rocky places around Ichang, alt. 100-900 m., April 1907 and June 1908 (No. 1837).

Viburnum Rosthornii Graebner in Bot. Jahrb. XXIX. 586 (1901).

Northwestern Szech'uan: Wa-ssu country, Wên-chuan Hsien, thickets, rare, alt. 2100 m., July $1908\left(\right.$ No. 220 $^{\text {b }}$; An Hsien, thickets, alt. 600 m., August 1910 (No. 4500). Eastern Szech'u an: Taning Hsien, thickets, alt. 600-900 m., June 1910 (No. 4497).

The specimens from eastern Szech'uan differ from those of western Szech'uan in the fulvous tomentum of the young branchlets and of the under side of the veins of the young leaves.

Viburnum rhytidophyllum Hemsley in Jour. Linn. Soc. XXIII. 355 (1888). - Rehder in Sargent, Trees and Shrubs, II. 39, t. 118 (1907).

Western Hupeh: north and south of Ichang, woods, alt. 13502250 m., May and September 1907 (No. 220, 220).

\section{Sect. MEGALOTINUS Maximowicz ${ }^{1}$}

Viburnum cylindricum Hamilton ex Don, Prodr. Fl. Nepal. 142 (1825). - Rehder in Sargent, Trees and Shrubs, II. 91, t. 143 (1908).

Viburnum coriaceum Blume, Bijdr. Fl. Ned. Ind. 656 (1825).

1 In my Conspectus of the Viburnums of eastern Asia (in Sargent, Trees and Shrubs, II. 108) I placed V. tomentosum and V. Hanceanum in the section Pseudotinus, but after a new study of the genus I have come to the conclusion that these two species are closer to the species of the section Megalotinus and particularly to $V$. Colebrookianum; this leaves Pseudotinus a very uniform and well defined group. 
Western Hupeh: north and south of Ichang, alt. 300-1200 m., June and December 1907 (No. 697). Western Szech'uan: Mupin, thickets, alt. 1500-1800 m., June and November 1908 (No. 697).

Viburnum tomentosum Thunberg, Fl. Jap. 123 (1784).

Western Hupeh: Chang-lo Hsien, open woods, alt. 1200-1800 m., June and September 1907 (No. 135); north and south of Ichang, woods, common, alt. 1500-2100 m., June and September 1907 (Nos. 234, 234 ${ }^{\mathrm{a}}$; Patung Hsien, woodlands, alt. $1500 \mathrm{~m}$., June and September 1907 (No. II7). Western Szech'uan: Wa-ssu country, Wênchuan Hsien, woodlands, alt. 1800 m., May 29, 1908 (No. I832).

No. 117 approaches $V$. tomentosum, var. lanceatum Rehder from Japan, but the leaves, although narrow and rather small, are abruptly acuminate as in the type, not gradually narrowed at the apex; they also have the close set veins of the type.

\section{Sect. TINUS Maximowicz}

Viburnum Davidii Franchet in Nouv. Arch. Mus. Paris, sér. 2, VIII. 251 (Pl. David. II. 69) (1885).

Western Szech'uan: southeast of Tachien-lu, alt. 1800-2400 m., June and October 1908 (No. 963, in part); Wa-shan, woodlands, alt. 1800-2100 m., October 1908 (No. 963); Mupin, woodlands, alt. 18002400 m., June 1908 and September 1910 (No. 963, in part).

Viburnum cinnamomifolium Rehder in Sargent, Trees and Shrubs, II. 31, t. 114 (1907); in Fedde, Rep. Sp. Nov. IX. 183 (1911).

Western Szech'uan: Mupin, thickets, alt. 1200-1500 m., October 1908 (No. I 108); Ya-chou Fu, thickets, alt. 1000 m., September 1910 (No. 4228).

Viburnum propinquum Hemsley in Jour. Linn. Soc. XXIII. 355 (1888). - Rehder in Sargent, Trees and Shrubs, II. 33, t. 115 (1907).

Western Hupeh: north and south of Ichang, cliffs, alt. 900-1200 m., May, June and October 1907 (No. 498); Patung Hsien, among rocks, alt. 900 m., June 1907 (No. I830); Hsing-shan Hsien, cliffs, alt. 1000 m., May 25 and August 1907 (No. 183r).

\section{Sect. ODONTOTINUS Rehd.}

Viburnum foetidum Wallich, Pl. As. Rar. I. 49, t. 61 (1830).

Western Szech'uan: southeast of Tachien-lu, thickets, alt. 1800 m., October 1908 (No. 1360). 
Viburnum foetidum, var. rectangulum (Graebner) Rehder in Sargent, Trees and Shrubs, II. 114 (1908).

Western Szech'uan: Mupin, thickets, alt. 900-1200 m., June and October 1908 (No. II3I). Western Hupeh: Patung Hsien, thickets, alt. 1200 m., July 1907 (No. 1833).

Wilson's specimens differ from the type of this variety in the broader generally elliptic leaves, but agree with it in the peculiar mode of growth, the thin texture and the nearly glabrous veins of the leaves.

Viburnum theiferum Rehder in Sargent, Trees and Shrubs, II. 43, t. 120 (1907); in Fedde, Rep. Sp. Nov. IX. 183 (1911).

Ki angsi: Kuling, thickets, abundant, alt. 1200 m., July 31, 1907 (No. I7II). Western Hupeh: north and south of Ichang, thickets, abundant, alt. 1200-2100 m., May and September 1907 (No. 218); Chang-lo-Hsien, thickets, alt. 1500-2100 m., September 1907 (No. 236).

Viburnum corylifolium Hooker f. \& Thomson in Jour. Linn. Soc. II. 174 (1858).

Western Hupeh: Chang-yang Hsien, thickets, alt. 1500 m., May 1907 (No. 447, as to the flowers).

Wilson's No. 447 agrees well with Henry's No. 11362 from Yunnan which I have referred to this species. $V$. corylifolium is closely related to $V$. dilatatum Thunberg and may perhaps be considered a variety of it; it is chiefly distinguished by the long hispid pubescence of the petioles, inflorescence and young branchlets. It seems doubtful whether $V$. dilatatum occurs in western China, and the only Chinese specimen I have seen is from the province of Chekiang, collected near Ningpo by D. Macgregor (Herb. Arnold Arboretum); Wilson's No. 944 which I referred formerly (Sargent Trees and Shrubs, II. 114) to that species probably belongs to $V$. brevipes Rehder.

Viburnum hirtulum Rehder in Sargent, Trees and Shrubs, II. 115 (1908); in Fedde, Rep. Sp. Nov. IX. 184 (1911).

Kiangsi: Kuling, thickets, 900-1200 m., July 28 and August 1, 1907 (Nos. I709, I712, immature fruit).

I refer Wilson's Nos. 1709 and 1712 with some hesitation to this species, the leaves are less pubescent, nearly glabrous above and less coriaceous than in the type, but the material is too incomplete to place the specimens definitively.

Viburnum Wilsonii Rehder in Sargent, Trees and Shrubs, II. 115 (1908); in Fedde, Rep. Sp. Nov. IX. 184 (1911).

Western Szech'uan: Mupin, thickets, alt. 1500-1800 m., June and October 1908 (Nos. 1025 ${ }^{\mathrm{a}}$, Ir20); Wa-ssu country, Wên-chuan Hsien, thickets, alt. 1800-2500 m., June 1908 and October 1910 (Nos. 1813, 4I96). 
These specimens differ somewhat from the type in the leaves being sparingly furnished with fasciculate hairs on the whole under surface and sometimes glabrous above, in the generally oblong-ovate shape of the leaves and in the stamens being slightly longer than the corolla lobes. The fruit is bright red, ovoid, about $8 \mathrm{~mm}$. high and furnished with scattered stellate hairs; the stone is broadly ovate, much compressed, pointed, one-ribbed on the dorsal and two-ribbed on the ventral side, about $6 \mathrm{~mm}$. high and $5 \mathrm{~mm}$. broad. $V$. hupehense Rehder, which much resembles this species in the velutinous tomentum of the inflorescence, differs chiefly in the stipulate petioles and the denser fasciculate pubescence, while the leaves of $V$. Wilsonii have mostly fasciculate hairs on the upper surface while young, becoming glabrous at maturity and are but slightly pubescent beneath.

Viburnum brevipes Rehder, n. sp.

Frutex erectus, $2-3 \mathrm{~m}$. altus ramulis junioribus dense stellatopilosis et hispidis tertio anno glabrescentibus, griseo-brunneis. Gemmae perulis 4 exterioribus fulvo-flavescentibus sparse adpresse setulosis. Folia breviter petiolata, membranacea oblongo-obovata, rarius obovata, subito acuminata, basi late cuneata, subito in petiolum contracta, dentata ima basi excepta, 5-7 cm. longa et 2-3.5 cm. lata, supra pilis fasciculatis tuberculis minutis insidentibus conspersa, subtus fasciculato-pilosa praesertim ad venas et glandulis numerosis interspersa, utrinsecus venis $6-8$ in dentes exeuntibus; petioli estipulati, $2-3 \mathrm{~mm}$. longi, dense hispidi. Corymbus $5-7 \mathrm{~cm}$. diam., radiis plerumque 5, fasciculato-pilosus; flores ignoti. Drupae plerumque in radiis tertii ordinis, ovoideae, rubrae; putamen ovoideum, acutum, valde compressum, circa $6 \mathrm{~mm}$. altum et $4.5 \mathrm{~mm}$. latum, dorso leviter bi-, ventre trisulcatum, testa minute punctulata, pallide purpureobrunnea.

Western Hupeh: Chang-yang Hsien, thickets, alt. 1300-1800, October 1907 (No. 447, as to the fruiting specimens, type), November 1907 (No. 676).

Viburnum brevipes bears in the shape of the leaves and in the very short petioles a great resemblance to $V$. erosum Thunberg, which, however, is easily distinguished by the stipulate petioles, by the different, not hispid, and often very slight pubescence of the inflorescence, petioles and branchlets, the absence of the glands on the under side of the leaves and by the smaller and less compressed stone. Its nearest relationship seems to be with $V$. dilatatum Thunberg, but that species is readily distinguished by its much longer petioles and broader leaves and by the generally forked hairs of the under side of the leaves. I am inclined to refer one of Wilson's Hupeh specimens collected in 1900 (Veitch Exped. No. 944), which is in flower, provisorily to this species on account of the short petioles, but the leaves have the shape of those of $V$. dilatatum. Viburnum brevipes is in cultivation and may be expected to flower soon.

Viburnum ovatifolium Rehder in Sargent, Trees and Shrubs, II. 115 (1908); in Fedde, Rep. Sp. Nov. 184 (1911). 
Western Hupeh: South Wushan, thickets, alt. 1500-1800 m., September 1907 (Nos. 224, 230); Hsing-shan Hsien, thickets, alt. 1200-1800 m., June, August and September 1907 (Nos. 240, 394, I817, I822); Fang Hsien, thickets, alt. 1800-2100 m., June 1907 (No. I8I9).

The Hupeh specimens differ from the type chiefly in the longer stamens, exceeding slightly the corolla-lobes, and in the occasionally broader leaves. The fruits, not yet described, are ovoid and bright red; stone ovoid, pointed, 3-6 mm. high and $4.5 \mathrm{~mm}$. broad, with one dorsal and two ventral ribs; testa light purplish brown.

Viburnum betulifolium Batalin in Act. Hort. Petrop. XIII. 371 (1894). - Rehder in Sargent, Trees and Shrubs, II. 99, t. 147 (1908).

Western Hupeh: Hsing-shan Hsien, thickets, alt. 1500-2000 m., June, July and November 1907 (Nos. 590, I816); north and south of Ichang, thickets, alt. 1500-1800 m., July and November 1907 (Nos. 238a, 249); Patung Hsien, thickets, alt. 1500 m., July and October 1907 (No. 400); Chang-yang Hsien, thickets, alt. 1350 m., December 1907 (No. 669). Western Szech'uan: Wa-ssu country, Wên-chuan Hsien, alt. 2100 m., July and September 1908 (No. I043); Tachien-lu, thickets and open woodlands, 2100-2400 m., June, July and October 1908 and October 1910 (Nos. I262, I263, I263 ${ }^{\mathrm{a}}$, I809, 4I28).

Wilson's No. 1043 differs rather strikingly from the type in its very small leaves with few veins and with few coarse or occasionally lanceolate and entire teeth, more pubescent corymb, smaller flowers with the stamens scarcely exceeding the corollalobes and in the smaller fruits.

Viburnum lobophyllum Graebner in Bot. Jahrb. XXIX, 589 (1901).Rehder in Sargent, Trees and Shrubs, II. 101, t. 148 (1908).

Western Hupeh: Hsing-shan Hsien, thickets, alt. 1800 m., July and September 1907 (Nos. 238, 393); north and south of Ichang, thickets, alt. 1500-1800 m., June and October 1907 (No. 4Ir). Western Szech'uan: Wa-ssu country, Wên-chuan Hsien, thickets, alt. 1800-2700, October 1908 (No. I025); October 1910 (Nos. 4I47, 4I94); Tachien-lu, thickets, alt. 2400-2700 m., June 1908 (No. I807).

No. 393 seems nearest to the type. No. 238 differs in its smaller leaves, smaller flowers and smaller fruits with the stones scarcely $5 \mathrm{~mm}$. high and ovoid. The seeds distributed under the same number are different and agree exactly with those of the type.

Viburnum lobophyllum, var. flocculosum Rehder, n. var.

Folia elliptico-ovata v. oblongo-ovata, acuminata acumine falcato, basi late cuneata, sinuato-dentata, supra glabra, subtus pilis fasciculatis albidis conspersa, costis media et secundariis fere glabris exceptis, 
5-12 cm. longa et 3-6 cm. lata; petioli glabri, stipulis minutis plerumque caducis instructi v. interdum estipulati. Corymbus laxe pubescens, ovariis glandulosis, calyce et corolla extus glabris. Drupae immaturae putamine ellipsoideo complanato, utrinque acuto. Ceterum ut in typo.

Western Szech'uan: Wa-ssu country, Wên-chuan Hsien, thickets, alt. 2100 m., July 1908 (No. I8I I, type); Ta-p'ao-shan, north-east of Tachien-lu, thickets, alt. 2100-2700 m., July 3, 1908 (No. I8I2); thickets around Tachien-lu, alt. 1500-1800 m., June 1908 (No. I808); upland thickets, alt. 2400-3000 m., October 1910 (No. 4I25); Panlan-shan, west of Kuan Hsien, alt. 2400 m., October 1910 (Nos. 4310, 4315).

Differs from typical $V$. lobophyllum chiefly in the slight floccose pubescence of the under side of the leaves which are usually cuneate at the base. In the shape of the leaves it bears some resemblance to $V$. Wilsonii Rehder, but is distinguished by its quite glabrous branchlets and petioles, the only slightly pubescent inflorescence, the glabrous winter-buds and the only slightly pubescent under side of the leaves. No. 1812 agrees in the shape and size of the leaflets exactly with No. 1811, the type of this variety, while No. 1808 has smaller leaves only from 5-7 mm. long.

Viburnum dasyanthum Rehder in Sargent, Trees and Shrubs, II. 103 t. 149 (1908); in Fedde, Rep. Sp. Nov. IX. 185 (1911).

Western Hupeh: Chang-yang Hsien, thickets, alt. 1200-1500 m., October 1907 (No. 463, 467); Fang Hsien, thickets, alt. 2100 m., July 1907 (No. I8I8); Patung Hsien, thickets, common, alt. 12001800 m., June and September 1907 (Nos. I820, I82I). Western Szech'uan: Wa-shan, thickets, alt. 1800-2250 m., June 1908 (No. r805); Wa-ssu country, Wên-chuan Hsien, thickets, alt. $2250 \mathrm{~m}$., July 1908 (No. I8ro).

Viburnum hupehense Rehder in Sargent, Trees and Shrubs, II. 116 (1908); in Fedde, Rep. Sp. Nov. IX. 185 (1911).

Western Hupeh: Hsing-shan Hsien, thickets, alt. 1500-1800 m., August and October 1907 (Nos. 237, 1823); Fang Hsien, thickets, common, alt. 1500-1800 m., June and November 1907 (No. 6or).

Viburnum ichangense (Hemsley) Rehder in Sargent, Trees and Shrubs, II. 105, t. 150 (1908); in Fedde, Rep. Sp. Nov. IX. 186 (1911).

Kiangsi: Kuling, abundant, alt. 1200 m., July 30, 1907 (No. I710). Western Hupeh: north and south of Ichang, woods, alt. 1500-2100 m., May and September 1907 (Nos. 228, 239); Hsing-shan Hsien, woodland thickets, alt. 1250-1800 m., June, September and October 1907 (Nos. 329, 392, I804); Fang Hsien, thickets, alt. 1800 m., Octo- 
ber 1907 (No. 392 a); Wushan Hsien, thin oak woods, alt. $1800 \mathrm{~m}$., September 1907 (No. 22I). Western Szech'uan: Wa-ssu country, Wên-chuan Hsien, thickets, alt. 2100 m., July 1908 (No. I8o6); October 1910 (No. 4I50). Chekiang: Ningpo, D. Macgregor (Herb. Arnold Arboretum). ${ }^{1}$

\section{Sect. OPULUS De Candolle}

Viburnum Sargentii Koehne in Gartenfl. XLVIII. 341 (1899).Rehder in Sargent, Trees and Shrubs, I. 83, t. 42 (1908).

Western Hupeh: Fang Hsien, thickets, alt. 1800-2400 m., July and October 1907 (No. 28I, in part); Hsing-shan Hsien, thickets, June 1907 (No. 28I, in part).

The specimen from Hsing-shan Hsien (in bud) represents the typical form, while those from Fang Hsien (flower and fruits) represent the var. calvescens Rehder.

Viburnum kansuense Batalin in Act. Hort. Petrop. XIII. 372 (1894).

Western Szech'uan: around Tachien-lu, thickets, rare, alt. 1500-2250 m., June and October 1908 (No. 859, in part); Sungpan, thickets, alt. 2400-2800 m., September 1910 (No. 859, in part).

The mature fruits, which have not yet been described, present a peculiar variation; they are bright red and on part of the specimens subglobose and $1 \mathrm{~cm}$. long, on the other specimens oblong and $1.5 \mathrm{~cm}$. long; the stone is much flattened, marked with five longitudinal lines and with scarcely noticeable ribs, ovoid and $8 \mathrm{~mm}$. long and $5 \mathrm{~mm}$. broad, or oblong and $12 \mathrm{~mm}$. long and $6 \mathrm{~mm}$. broad in the large-fruited specimens.

\section{TRIOSTEUM L. ${ }^{2}$}

Triosteum Fargesii Franchet in Jour. de Bot. X. 319 (1896).

Western Hupeh: Hsing-shan Hsien, woodlands, alt. 1800-2300 m., May 29 and August 1907 (No. I99); Fang Hsien, uplands, alt. 2100-2700 m., June and October 1910 (Nos. 4489, 4456).

The fruits are white according to Wilson.

1 An interesting addition to the Viburnums of China proper is the following species hitherto only known from Formosa.

Viburnum luzonicum Rolfe, var. formosanum (Hance) Rehder in Sargent, Trees and Shrubs, II. 97 (1908).

Fokien: without locality, S. T. Dunn, 1905 (Herb. Hongkong Bot. Gard., No. 2763 in Herb. Arnold Arboretum).

The specimen from Fokien differs slightly from the Formosa plant in the stamens being as long as the corolla lobes.

${ }^{2}$ Though Triosteum contains no woody species, it may find a place here to make the enumeration of the Chinese Caprifoliaceae collected by Wilson complete. 
Triosteum himalayanum Wallich, var. chinense Diels \& Graebner in Bot. Jahrb. XXIX. 590 (1901).

Western Szech'u an: Mupin, uplands, alt. 2400-2700 m., August 1908 (No. 876); Tachien-lu, uplands, alt. 3000-3600 m., September 1910 (No. 4I6I).

Wilson gives the color of the fruits of No. 876 as red and of No. 4161 as white, but I cannot detect the slightest difference in the dried specimens.

Triosteum Rosthornii Diels \& Graebner in Bot. Jahrb. XXIX. 591, f. 5, c-e (1901).

Western Hupeh: Fang Hsien, uplands, alt. 2400-2700 m., October 1908 (No. 2339). Western Szech'uan: Wa-ssu country, Wênchuan Hsien, uplands, alt. 2400-2800 m., July 1908 (No. 2340).

\section{SYMPHORICARPOS JusS.}

\section{Symphoricarpos sinensis Rehder, n. sp.}

Frutex erectus 1-1.75 m. altus, glaberrimus, ramulis gracilibus, hornotinis initio viridibus v. purpurascentibus, demum rubrobrunneis, annotinis peridermate lamellis tenuibus decorticante et corticem fibrosum detegente. Gemmae parvae, brunneae, perulis pluribus exterioribus acutis. Folia ovalia v. rhombico-ovata, acuta v. obtusiuscula, basi late cuneata et sensim in petiolum gracilem attenuata integerrima, $1.5-2.5 \mathrm{~cm}$. longa et $1.2-1.8 \mathrm{~cm}$. lata, supra laete viridia, subtus glaucescentia, utrinsecus 4-6-costata; petioli teretes, 1-2 $\mathrm{mm}$. longi. Flores sessiles, solitarii in axillis bractearum subulatarum ovariis breviorum, bracteis inferioribus interdum foliaceis et longioribus, spicas terminales 6-12-floras pedunculo $0.5-2 \mathrm{~cm}$. longo insidentes formantes; ovaria lageniformia, basi bracteolis ovatis quartam partem ovarii aequantibus suffulta, quadri-locularia loculis duobus sterilibus; calycis dentes ovato-lanceolati, acuti, circa $1 \mathrm{~mm}$. longi; corolla late campanulata, alba, $7 \mathrm{~mm}$. longa, intus extusque glabra, lobis ovatis tubum leviter ventricosum subaequantibus; stamina filamentis paullo infra faucem affixa, corollam subaequantia, antheris oblongis albidis; stylus glaber, stamina aequans, stigmate capitato. Bacca ovoidea, $7 \mathrm{~mm}$. longa, atrocoerulea, pruinosa, apice in rostrum brevem quinquedentatum subito contracta, disperma, pulpo viridi, seminibus ovoideis, $5 \mathrm{~mm}$. longis, dense pilosis, albidis.

Western Hupeh: Fang Hsien, Ta-pa-shan, thickets, rare, alt. 2300 m., July 1907 (No. 718). - In cultivation at the Arnold Arboretum. 
The discovery of a Chinese Symphoricarpos is highly interesting, as it adds one more genus to the number of those formerly considered peculiar to the flora of North America, but in recent years found also in western and central China, as Nyssa, Sassafras, Liriodendron, Decumaria and others. In the shape of the corolla $S$. sinensis resembles most $S$. orbiculatus Michaux, but the color of the fruit and the terminal peduncled inflorescence distinguishes it from all American species.

\section{DIPELTA Maxim.}

Dipelta floribunda Maximowicz in Bull. Acad. Sci. St. Pétersbourg, XXIV. 51 (1877); in Mél. Biol. X. 78. - Spooner in Gard. Chron. ser. 3, XLII. 2, fig. 1 (1907). - Hemsley in Bot. Mag. CXXXVI. t. 8310 (1910).

Western Hupeh: Patung Hsien, woodlands, alt. 1200-1500 m., August 1907 (No. 2952); Hsing-shan Hsien, thickets, common, alt. 1200-1500 m., May 7, 25, and July 1907 (Nos. 2953, 2954, 2955); Fang Hsien, sunny places, alt. 1200-1800 m., October 1910 (No. 4424).

Dipelta ventricosa Hemsley in Gard. Chron. ser. 3, XLIV. 101, fig. 37 (1908). - Hutchison in Bot. Mag. CXXXVI. t. 8294 (1910).

Western Szech'uan: southeast of Tachien-lu, thickets, alt. 2250 m., June 1908 (No. 2950); Wa-shan, woodlands, alt. 24002700 m., June 1908 (No. 295I); Ching-ting-shan, thickets, alt. 1200-1500 m., May 22, 1908 (No. I036); Mupin, woods, alt. 1800$2500 \mathrm{~m}$., June and October 1908 and October 1910 (Nos. 1036a , 4209); Wa-ssu country, Wên-chuan Hsien, woodlands, alt. 1800-2500, July and September 1908 (No. I036); northeast of Sungpan, thickets, alt. 1800-2300 m., August 1910 (No. 4032).

Nos. $1036^{\mathrm{a}}$ and 2950 differ from the plant described by Hemsley and from the other specimens in the quite glabrous peduncles, pedicels and branchlets and in the less pubescent leaves. Nos. 1036 and 2950 have apparently much paler flowers ("pale purple" according to Wilson), than the type.

\section{ABELIA R. Br.}

Abelia Graebneriana Rehder, n. sp.

Abelia uniflora Hemsley in Jour. Linn. Soc. XXIII. 359 (in part as to the Hupeh and Szech'uan specimens, not R. Brown) (1888).

Abelia serrata Hance in Jour. Bot. XX. 6 (not Siebold \& Zuccarini) (1882).

Linnaea uniflora Graebner in Bot. Jahrb. XXIX. 131 (in part as to the Hupeh and Szech'uan specimens, not A. Braun \& Vatke) (1900).

Linnaea serrata Graebner in Bot. Jahrb. XXIX. 133 (in part as to the Chinese specimens) (1900). 
Frutex gracilis ramulis fusco-purpureis, junioribus glabris v. interdum minute puberulis. Folia membranacea, ovata v. elliptico-ovata, rarius oblongo-ovata, acuminata, basi cuneata, $3-5.5 \mathrm{~cm}$. longa et 1.5-3 cm. lata, basi apiceque exceptis serrulata serraturis parvis mucronulatis, supra laete viridia, plerumque praecipue ad marginem ciliatam versus sparse adpressa pilosa, subtus pallidiora, secus costam mediam et venas basin versus villosa, interdum ad costam venasque sparse pilosa, rarius fere glabra; petioli glabri, $2-4 \mathrm{~mm}$. longi. Pedunculi uniflori, breves in apice ramulorum brevium plures, rarius solitarii; bracteolae ciliatae; ovaria subteretia, sparse pilosa; sepala oblongo-lanceolata v. oblongo-ovata, obtusa v. acutiuscula, glabra v. sparsissime ciliata; corolla albida v. pallide rosea, $2.5 \mathrm{~cm}$. longa, campanulato-infundibuliformis e basi tubulosa fere tertiam partem corollae formante sensim ampliata, limbo subpatulo circa $2 \mathrm{~cm}$. diam., extus sparse pilosula glandulosaque, fauce villosa; stylus limbum medium attingens, stamina longiora paullo superans. Achaenia subteretia, costata, 7-8 $\mathrm{mm}$. longa, sparse pilosa.

Western Hupeh: Chang-lo Hsien, thickets, alt. 900-1200 m., June 1907 (No. 2017, type); Fang Hsien, woodlands, alt. 1500-2300 m., June 11 and October 1910 (No. 4422); without locality, May 1900 (Veitch Exped. Nos. 267, 267a); Ichang, A. Henry (No. 3436); without locality, A. Henry (No. 1768). Western Szech'uan: Chin-tingshan, thickets, alt. 1200 m., May 25, 1908 (No. 2018); Mupin, thickets, alt. 1200-1800, June 1908 and October 1910 (Nos. 2020, 4380); Mt. Omei, May 1904 (Veitch Exped. No. 5031); without locality, July 1904 (Veitch Exped. No. 3720).

Closely allied to $A$. uniflora $\mathrm{R}$. Brown, which is easily distinguished by its subcoriaceous glabrous leaves, the 1-3-flowered inflorescence at the end of elongated branchlets and the more campanulate corolla with a shorter and wider tube. Abelia Graebneriana is somewhat variable in foliage and also in the flowers; the most distinct forms are represented by the following three numbers: No. 267 differs in its narrower glabrescent leaves usually only with one to three teeth on each side, the narrower ones being about $4 \mathrm{~cm}$. long and $1 \mathrm{~cm}$. broad, in the longer sepals, the larger corolla, nearly $3 \mathrm{~cm}$. long with longer and slenderer tube, and in the lateral flowering branchlets being usually reduced to fascicles of leaves; No. 2020 has ovate, indistinctly crenulate-serrulate leaves, obtusely acuminate, and smaller flowers, scarcely exceeding $2 \mathrm{~cm}$. in length; No. 4380 has much smaller leaves not exceeding $2.5 \mathrm{~cm}$. and oval sepals, the flowers are wanting.

To this species is probably related Linnaea serrata, var. Hegii (Graebner [p. sp.] in sched.) Pampanini in Nuov. Giorn. Bot. Ital. n. ser. XVII. 722 (1910) from Shensi, G. Giraldi, and from Hupeh, Mts. of Fan-sien, C. Silvestri (No. 1825), chiefly characterized by ciliate sepals puberulous on the outside; it is possibly a distinct species. 
Abelia Engleriana Rehder, n. comb.

Linnaea Engleriana Graebner in Bot. Jahrb. XXIX. 132 (1900).

Western Hupeh: Fang Hsien and Hsing-shan Hsien, thickets, alt. 1200-1600 m., June and September 1907 (No. 289); Ichang, $A$. Henry (No. 1737). Szech'uan: Taning Hsien, cliffs, alt. 600-900 m., July 1910 (No. 449I); no locality, A. Henry (Nos. 5563, type!, 5573); Chan-chia-shan, Nanch'uan, A. v. Rosthorn (No. 34).

Rosthorn's No. 34 differs from the type specimen and from Wilson's specimens, which have quite glabrous branchlets in its puberulous and sparingly pilose branchlets; and the inflorescence does not seem typical. Henry's No. 1737 resembles in foliage somewhat $A$. macrotera (Graebn.) Rehder, but the flowers are those of A. Engleriana, though borne at the end of short elongated branchlets.

Abelia myrtilloides, Rehder, n. sp.

Frutex metralis ramulis gracilibus, junioribus puberulis rubrobrunneis, annotinis fuscis peridermate decorticante. Folia ovata v. ovatooblonga v. ovato-lanceolata, acuta v. obtusiuscula et plerumque mucronulata, basi late cuneata, margine revoluta et integra, 1-1.5 $\mathrm{cm}$. longa et 4-7 mm. lata, supra obscure viridia, glabra pilis paucis setosis ad marginem versus exceptis, subtus pallida v. cinereo-viridia, venis inconspicuis, glabra pilis villosis ad partem inferiorem costae mediae exceptis; petioli glabri, $1 \mathrm{~mm}$. longi. Flores axillares in apice ramulorum elongatorum, graciliter pedunculati pedunculis puberulis $3 \mathrm{~mm}$. longis medio bracteis minutis linearibus institutis; ovarium teres, adpresse pilosum, circa $5 \mathrm{~mm}$. longum; sepala 2, elliptica, ciliata, 7-9 mm. longa et 4-5 mm. lata; corolla campanulato-infundibuliformis, infra medium anguste tubulosa supra sensim ampliata, intus hirsuta, extus glabra, circa $3 \mathrm{~cm}$. longa, roseo-purpurea, lobis late ovatis $4 \mathrm{~mm}$. longis; stamina glabra, longiora medium limbum attingentia; stylus glaber, staminibus paullo brevior. Fructus maturi desiderantur.

Western Szech'uan: cliffs, alt. 600-700 m., June 1903, (Veitch Exped. No. 3722, type); valley of Min River near Sungpan, dry places, alt. 2100-2400 m., August 1910 (No. 4495).

Abelia myrtilloides is closely related to $A$. parvifolia Hemsley, which is easily distinguished by its densely pubescent and glandular leaves generally broader and rounded at the base, the short-peduncled flowers and by its longer and narrower sepals. It is also allied to $A$. Schumannii Rehder, which differs in its broader and larger usually sparingly serrate and thinner leaves pilose on the upper surface, and in its smaller flowers with the tube much shorter and borne on very short peduncles. 
Abelia Schumannii Rehder, n. comb.

Linnaea Schumannii Graebner in Bot. Jahrb. XXIX. 130 (1900).

Western Szech'uan: Wa-ssu country, Wên-chuan Hsien, thickets, alt. 1200-1800 m., July and November 1908 (No. I230); Min Valley, near Mao-chou, dry region, alt. 1200-1800 m., May 25, 1908 (No. 20I9); Lungan Fu, sunny places, alt. 1200-1800 m., August 1910 (No. 4494); Tachien-lu, alt. 2700-3600 m., A. E. Pratt (No. 271, type!); Chinlin, Nanch'uan, river banks, August 15, 1891, A. von Rosthorn (No. 459).

Abelia parvifolia Hemsley in Jour. Linn. Soc. XXIII. 358 (1888).

Linnaea parvifolia Graebner in Bot. Jahrb. XXIX. 129 (1900).

Western Hupeh: hills around Ichang, common, alt. 30-300 m., July 1907 (No. 747); Ichang, A. Henry (No. 4225). Western Szech'uan: Lungan Fu, rocky places, alt. 1200-1500 m., August 1910 (No. 4493).

Abelia chinensis R. Brown in Abel, Narrat. Jour. China, 376, tab. (1818).

Linnaea chinensis A. Braun \& Vatke in Oesterr. Bot. Zeitschr. XXII. 291 (1872).

Abelia Hanceana Martens apud Hance in Ann. Sci. Nat. sér. 5, V. 216 (1866).

Western Hupeh: around Ichang, common, alt. 600 m., July 1907 (No. 2024); no locality, July 1900 (Veitch Exped. No. 1420); no locality, A. Henry (No. 35); Nant'o, A. Henry (No. 2688). Kwangtung: no locality, C. Ford (No. 94); Lienchow River, August 19, 1887, C. Ford (No. 1795).

Abelia Zanderi Rehder, n. comb.

Linnaea Zanderi Graebner in Bot. Jahrb. XXIX. 142 (1900).

Western Szech'uan: dry regions near Mong-kong-ting, thickets, alt. 1800-2400 m., June 1908 (No. 202I); Pan-lan-shan, west of Kuan Hsien, thickets, alt. 2100-2400, June 1908 (No. 2022); no locality, June 1904 (Veitch Exped. No. 3721). Shensi: Han-cheng-sien, 1909, Wm. Purdom (No. 320). Western Hupeh: Fang Hsien, thickets, alt. 1500-2000 m., June 16, 1910 (No. 4492).

I have not seen the type of this species, but at least one part of the specimens quoted here of this apparently very variable species agrees well with Graebner's description. The length and shape of the sepals varies considerably; in No. 3721 they are as long or slightly longer than the corolla-tube, linear-oblong and acutish, while in Nos. 2021 and 2022, they are about two thirds as long, oblanceolate and 
obtuse. The peduncles in No. 3721 are 6-8 mm. long, in No. 2022 the pedicels are more or less separate so that the flowers are pedicelled and the common peduncle is sometimes very short, similar to the inflorescence of $A$. biflora Turczaninow. The leaves are also very variable; in No. 2021 they are narrowly lanceolate and quite entire, and in No. 4210 lanceolate-oblong and nearly entire, while in No. 2022 and in Purdom's No. 320 at least part of the leaves are elliptic and coarsely toothed and in No. 4492 the leaves are oblong-lanceolate and almost all serrate. The flowers are fragrant, the tube nearly tubular and the limb spreading.

\section{Abelia umbellata, n. comb.}

Linnaea umbellata Graebner \& Buchwald in Bot. Jahrb. XXIX. 143 (1900).

Western Hupeh: Hsing-shan Hsien, woodlands, alt. 1200-1800 m., June, Nov. 1907 (No. 607); without locality, June 1900 (Veitch Exped. No. 922). Szech'uan: A. Henry (No. 7083, type).

The corolla, not described by Graebner, is narrowly funnel-form or nearly tubular, white, 15-18 mm. long, with spreading limb, $3 \mathrm{~mm}$. long; the style slightly exceeds the tube and the stamens just reach the mouth; the sepals are nearly as long as the tube or somewhat shorter.

The determination of Wilson's collection and other unnamed material in the herbarium of the Arnold Arboretum led me to study all the Asiatic species, and in consequence to a rearrangement of the species, differing in several points from the grouping as proposed by Maximowicz (in Mél. Biol. XII. 473-480), Zabel (in Mitt. Deutsch. Dendr. Ges. II. 32-34) and Graebner (in Bot. Jahrb. XXIX. 120-145). To show clearly the arrangement I have adopted, a synopsis of the whole genus is appended here.

\section{SYNOPSIS OF THE GENUS ABELIA.}

Abelia has been by several writers united with Linnaea and treated as a subgenus of the latter, but there does not seem to be a very convincing reason for the union of these two genera; there are no intermediate forms, and sufficient characters in the ovary and the fruit, as well as in the calyx and in the corolla and in the habit of the plants to keep Abelia as a distinct genus. At present 27 species of Abelia may be distinguished which can be divided into two sections well marked by differences in the vegetative and reproductive parts and easily recognized even without flowers or fruits. The first section Euabelia, with $A$. chinensis as the type, is characterized by the petioles not being dilated at the base and not enclosing the winter-buds, by the absence of recurved hispid hairs on the young branchlets, the lighter or darker brown color of the bark separating in flakes, the more or less funnel form or nearly campanulate shape of the corolla and the terete or nearly terete akenes. The second section, Zabelia, which I take pleasure in associating with the name of $\mathrm{H}$. Zabel, who first proposed a good division of the genus into sections, is characterized by the petioles being dilated at the base with the opposite ones connate and covering the winter-buds and persistent on the branchlets of the previous year, by the young branchlets being furnished with reflexed hispid hairs or rarely glabrous, by the tubular corolla with spreading limb, by the stamens not exceeding the tube and the scarcely exserted style, and by flattened akenes usually more or less curved. The several subsections or series as here limited have well defined geographical ranges; the first, Serratae, is Japanese, the second and third, Uniflorae and Rupestres, range 
from eastern to western China, the fourth, Vesaleae, is Mexican, the fifth, Corymbosae, is Central Asiatic, while the last, Biflorae, extends from Mongolia to western China.

\section{KEY OF THE SPECIES.}

* Ramuli pilis villosis $\nabla$. patentibus instructi v. puberúlis v. glabri, nodis non incrassatis; petioli basi non dilatati nec connati; corolla campanulatoinfundibuliformis staminibus styloque faucem superantibus; achaenia teretia v. subteretia.

Sect. I. EUABELIA.

† Pedunculi semper biflori, solitarii in apice ramulorum lateralium brevium; ramuli solidi medulla angusta. . . . . . Subsect. 1. SERRATAE. Sepala 5. . . . . . . . . . . . . 1. A. spathulata. Sepala 2.

Folia parva ad $3 \mathrm{~cm}$. longa; sepala apice 2-3-dentata; corolla $1.5 \mathrm{~cm}$. longa, apicem versus sensim ampliata, limbo suberecto, rosea.

2. A. serrata.

Folia majora, ad $6 \mathrm{~cm}$. longa; sepala apice plerumque obtusa v. obtusiuscula, rarius leviter excisa.

Achaenia pilosa; sepala ovata; folia serrata; corolla $2 \mathrm{~cm}$. longa, infundibuliformis, limbo patente, lactea. . . . . . 3. A. Buchwaldii. Achaenia glabra; sepala lanceolata; folia parcius serrata v. fere integra.

4. A. gymnocarpa.

$\dagger \dagger$ Pedunculi uniflori, rarius pluriflori, axillares, saepe apice ramulorum inflorescentias pluri- $\nabla$. multiflores formantes.

‡ Sepala 2; stamina quam corolla breviora; pedunculi uniflori; ramuli anguste fistulosi. . . . . . . . . Subsect. 2. UNIFLORAE.

Folia acuminata.

Ramuli glabri (in A. uniflora interdum puberuli).

Corolla 2.5-3 cm. longa, sepalis triplo longior, plerumque e tubo angusto paullo infra medium $v$. medio ampliata.

Folia integra v. minute obsoleteque denticulata, 4-7 cm. longa, longe acuminata; pedunculi axillares pluriflori.

Folia serrulata v. dentata.

5. A. macrotera.

Corolla e medio ampliata, infra medium anguste tubularis; pedunculi uniflori, axillares in apice ramulorum elongatorum; folia parva, $1.5-2.5 \mathrm{~cm}$. longa, serrulata.

6. A. longituba.

Corollae pars tubularis vix tertiam partem corollae formans; folia $3-6 \mathrm{~cm}$. longa.

Folia subcoriacea, glabra. Pedunculi 1-3-flori in apice ramulorum elongatorum inflorescentias plurifloras formantes; corolla fere campanulata, basi breviter tubulosa.

7. A. uniflora.

Folia membranacea plerumque pilosa. Pedunculi uniflora in apice ramulorum brevium, corollae pars tubularis fere tertiam partem corollae formans.

8. A. Graebneriana.

Corolla 1.5-2 $\mathrm{cm}$. longa, e tubo brevi campanulata, sepalis duplo longior; flores in apice ramulorum brevium.

9. A. Engleriana. 
Ramuli juniores puberuli, virides; folia oblongo-lanceolata, integra v. interdum paucidentata, $1.5-3 \mathrm{~cm}$. longa et 5-12 $\mathrm{mm}$. lata; corolla $2 \mathrm{~cm}$. longa. . . . . . . . 10. A. Koehneana.

Folia acuta v. obtusa, parva, 1-2.5 cm. longa, discoloria, chartacea v. subcoriacea; pedunculi uniflori, plerumque in apice ramulorum elongatorum inflorescentias pluriflores formantes; ramuli puberuli et sparse pilosi.

Folia eglandulosa, subtus ad costam villosa. Corolla parva, 1-1.5 cm. longa, anguste infundibuliformis. . . . . 11. A. tereticalyx. Corolla campanulato-infundibuliformis, $2.5 \mathrm{~cm}$. longa, infra medium subito ampliata, limbo $1.5-2 \mathrm{~cm}$. diam.; folia margine plana.

12. A. Schumannii.

Corolla infundibuliformis, $2.5 \mathrm{~cm}$. longa, supra medium sensim ampliata, limbo $8 \mathrm{~mm}$. diam., folia margine revoluta.

13. A. myrtilloides.

Folia utrinque puberula et glandulosa; corolla $2.5 \mathrm{~cm}$. longa, campanulato-infundibuliformis ......... 14. A parvifolia.

¥ Sepala 5; stamina stylusque plus minus exserta.

Inflorescentiae axillares, bi- v. pluriflorae in apice ramulorum paniculas plerumque multiflores formantes; stamina limbum superantia; medulla ramulorum angusta, solida v. partim evanescens.

Folia parva, 5-10 mm. longa, late ovata, acutiuscula.

Subsect. 3. RUPESTRES.

15. A. Aschersoniana.

Folia majora, ovata v. oblongo-ovata, acuta v. acuminata.

Folia concoloria, acuta, basi cuneata; sepala 8-10 mm. longa, tubo corollae parum breviora. . . . . . . . 16. A. rupestris.

Folia discoloria, acuminata, basi plerumque rotundata; sepala 4-5 $\mathrm{mm}$. longa, tubo corollae dimidio breviora.

17. A. chinensis.

Inflorescentiae axillares, uniflorae, racemos breves terminales formantes; stamina limbo breviora; medulla ramulorum angusta, solida.

Subsect. 4. VESALEAE.

Corolla 4-5 cm. longa; folia crenata, ciliata, membranacea.

18. A. floribunda.

Corolla 1.5-2 cm. longa; folia saepissime integra, glaberrima, coriacea.

19. A. coriacea.

** Ramuli pilis setosis reflexis instructi, rarius glabri, nodis incrassatis, medulla ampla solida; petioli basi dilatati et connati gemmas axillares obtegentes et in ramulis annotinis speciem stipularum intrapetioliarium formantes; pedunculi bi- v. tri-, rarius pluriflori; corolla tubuloso-infundibuliformis, tubo cylindrico, limbo patente, staminibus inclusis, stylo vix exsertis; achaenia compressa, saepius curvata. . . . . Sect. II. ZABELIA.

Pedunculi axillares plerumque triflori in apice ramulorum paniculam subcapitatam formantes ...... Subsect. 5. CORYMBOSAE. Sepala 5, filiformia, pinnato-pilosa . . . . 20. A. triflora. Sepala 4, lineari-lanceolata v. elliptica.

Sepala lineari-lanceolata, corollae tubo duplo vel quadruplo breviora.

Sepala lanceolata v. elliptica, corollae tubo vix breviora.

21. A. angustifolia.

22. A. corymbosa.

Pedunculi biflori v. rarius pluriflori in apice ramulorum plerumque brevium solitarii; sepala 4 ....... Subsect 6. BIFLORAE. 
Pedunculi biflori.

Pedunculi nulli; pedicellis usque ad basin libera; folia plerumque serrata.

Pedunculi 0.5-1.2 cm. longi.

Folia acuminata.

Folia lanceolata discoloria, integra, subtus glaberrima.

24. A. Dielsii.

Folia ovato-oblonga, rarius lanceolata integra v. paucidentata concoloria subtus pubescentia . . . . . 25. A. Zanderi.

Folia obtusa, apice crenato-serrata, glabra, subdiscoloria.

26. A. onkocarpa.

Pedunculi 5- ad 7-flori; folia ovato-oblonga v. ovata, acuta v. obtusiuscula.

27. A. umbellata.

\section{ENUMERATION OF THE SPECIES.}

Sect. I. EUABELIA Rehder, n. sect. (see p. 123).

Ser. 1. SERRATAE, Graebner in Bot. Jahrb. XXIX, 126, 131 (1900).

Biflorae Zabel in Mitt. Deutsch. Dendr. Ges. II. 33 (in part) (1893).

1. Abelia spathulata Siebold \& Zuccarini, Fl. Jap: I. 77, t. 34, fig. 2 (1835). Hooker f. in Bot. Mag. CVIII. t. 6611 (1882).

Abelia serrata A. Gray in Perry, Narr. Exped. China Jap. II. 313 (secundum specimen authent.) (1856).

Linnaea spathulata Graebner in Bot. Jahrb. XXIX. 142 (1901).

Japan: Hondo (Maximowicz, C. Wright, C. S. Sargent, K. Watanabe, J. G. Jack, Faurie (No. 6837, 6838); Kiusiu (Rein ex Graebner).

2. Abelia serrata Siebold \& Zuccarini, Fl. Jap. I. 77, t. 34 (1835).

Linnaea serrata Graebner in Bot. Jahrb. XXIX. 133 (1900).

Japan: Hondo, Siebold, K. Miyabe; Shikoku, Nanokawa, Tosa, June 11, 1888, $K$. Watanabe; Kiusiu (Siebold ex Graebner).

Abelia serrata has sometimes been confounded with $A$. uniflora $\mathrm{R}$. Brown, but that species is easily distinguished by its axillary, one-flowered or sometimes threeflowered peduncles. The Chinese specimens identified by some botanists with $A$. serrata belong to A. Graebneriana Rehder, a species closely related to A. uniflora, but in foliage rather similar to $A$. serrata.

3. Abelia Buchwaldii Rehder, n. comb.

Linnaea Buchwaldii Graebner in Bot. Jahrb. XXIX. 133 (1900).

Japan: Hondo, Nagasaki, Maximowicz, 1863!, Ushiroyama, Mimasaki, S. Arimoto, 1903.

Graebner describes the sepals as ciliate, but I find them glabrous in Maximowicz's specimen, while in Watanabe's specimen of $A$. serrata the sepals are sparingly ciliate; Arimoto's specimen which has the sepals ciliate, is without flowers and I am not sure whether it really belongs here or to the following species; the akenes are glabrous, but also in Maximowicz's specimen they are only very sparingly pilose even in a young state.

4. Abelia gymnocarpa Rehder, n. comb.

Linnaea gymnocarpa Graebner in Bot. Jahrb. XXIX. 134 (1900).

Japan: Hondo, between Kioto and Maizura, Tomba, Doederlein (ex Graebner); Adera, Shinano, J. G. Jack, September 5, 1905.

I have not seen the type specimen, but Jack's specimen from Adera, which is without flowers, seems to agree well with Graebner's description except that the sepals are not strictly lanceolate. 
Ser. 2. UNIFLORAE Graebner in Bot. Jahrb. XXIX. 126, 129 (emend.) (1900).

5. A. macrotera Rehder, n. comb.

Linnaea macrotera Graebner \& Buchwald in Bot. Jahrb. XXIX. 131 (1900).

Hupeh: A. Henry (Nos. 6398, type, 1893).

I refer to this species also Henry's No. 1893, though it differs slightly in the thinner, less prominently veined leaves always cuneate at the base, while in No. 6398 they are rounded on part of the branches.

6. Abelia longituba Rehder, n. sp.

Frutex gracilis ramulis purpureo-fuscis glabris. Folia decidua brevi-petiolata, elliptico-ovata v. oblongo-lanceolata, basi cuneata, plerumque acuminata, apice obtusiuscula mucronulataque, pauci-serrulata, supra laete viridia, glabra pilis sparsis ad marginem exceptis, subtus pallida, sparse glandulosa ad costam tantum villosula v. glabra, $1.5-2.5 \mathrm{~cm}$. longa, $5-8 \mathrm{~mm}$. lata. Pedunculi uniflori, axillares in apice ramulorum brevium, medio bracteis duobus subulatis ciliolatis, apice bracteolis quattuor ovatis ciliolatis instituti; sepala oblonga, obtusa 8-10 mm. longa, glabra; corolla infundibuliformis, calyce triplo longior, $3 \mathrm{~cm}$. longa, infra medium anguste tubularis, e medio apicem versus ampliata, limbo patulo, 1.5-2 cm. diam., extus minute puberula, fauce intus subvillosa, staminibus longioribus styloque tubum subaequantibus. Achaenia sub anthesi $6 \mathrm{~mm}$. longa, subteretia, leviter costata, glabra.

Hupeh: A. Henry (No. 1356).

Abelia longituba is closely related to $A$. uniflora, but from this and the other allied species easily distinguished by the long and slender tube of the corolla and the small leaves.

7. Abelia uniflora R. Brown in Wallich, Pl. As. Rar. I. 15 (1830). - Lindley in Bot. Reg. XXXII. text to t. 8 (1846). - Lindley \& Paxton, Flow. Gard. II. 145, fig. 208 (1852). - Fl. Serres, VII. 227, fig. (1852). - Hooker in Bot. Mag. LXXIX. t. 4694 (1853). - Planchon in Fl. Serres, VIII. t. 824 (1853). - Morren in Belg. Hort. III. 338, t. (1853). - Jour. Hort. Prat. Guide Jard. XI. 129, t. (1853). - Lemaire in Jard. Fleur. IV. t. 380 (1854). - Maximowicz in Bull. Acad. Sci. St. Pétersbourg XXXI. 56 (1886); in Mél. Biol. XII. 476.

Linnaea uniflora, A. Braun \& Vatke in Oesterr. Bot. Zeitschr. XXII. 291 (1872). - Graebner in Bot. Jahrb. XXIX. 131 (in part) (1900).

Chin a: Fokien, Reeves (ex R. Brown), R. Fortune (ex Lindley).

Of this species $I$ have seen only specimens from cultivated plants which agree perfectly with the figure published by Hooker. According to Maximowicz the type specimen has smaller flowers and Lindley's figure shows the leaves slightly hairy, but I do not think that the type and Lindley's plant are different from the plant now in cultivation. Abelia uniflora has been made to include the plant of western China now described as A. Graebneriana, and even the Japanese A. serrata Siebold \& Zuccarini, but the latter differs markedly in its two-flowered terminal peduncles, and belongs to another group, and the former, though closely related, is certainly sufficiently distinct to form a separate species.

8. Abelia Graebneriana Rehder. See p. 118.

9. Abelia Engleriana (Graebn.) Rehder. See p. 120.

10. Abelia Koehneana Rehder, n. comb.

Linnaea Koehneana Graebner in Bot. Jahrb. XXIX. 132 (1900).

Szech'uan: A. von Rosthorn (No. 1843).

Easily distinguished from the allied species by the puberulous and green young branchlets and the very narrow leaves. 
11. Abelia tereticalyx Rehder, n. comb.

Linnaea tereticalyx Graebner in Bot. Jahrb. XXIX. 130 (1900).

China: Szech'u an: Tibet frontier, alt. $3000-4500$ m., A. E. Pratt (No. 136).

Of this species I have seen only a specimen of Pratt's No. 136 without fully developed flowers. It seems closely related to $A$. Schumannii, but differs in the smaller flowers and in the narrower leaves.

12. Abelia Schumannii (Graebn.) Rehder. See p. 121.

13. Abelia myrtilloides Rehder. See p. 120.

Ser. 3. RUPESTRES Zabel in Mitt. Deutsch. Dendr. Ges. II. 33 (emend.) (1893).

15. A. Aschersoniana Rehder, $\mathrm{n}$, comb.

Linnaea Aschersoniana Graebner in Bot. Jahrb. XXIX. 139 (1900).

Chin a: Kwang-tung, Lantao Island, C. Ford.

16. Abelia rupestris Lindley in Bot. Reg. XXXII. t. 8 (1846). - Lindley \& Paxton, Flow. Gard. II. 130, fig. 201 (1852).

Linnaea rupestris A. Braun \& Vatke in Oesterr. Bot. Zeitschr. XXII. 291 (1872).

Chin a: Fokien, Chamoo Hills (ex Lindley).

I have seen no specimen of this species. According to the descriptions the differences between this and the following seem very slight and both may belong to the same species.

17. Abelia chinensis R. Br. See p. 121.

Ser. 4. VESALEAE Zabel in Mitt. Deutsch. Dendr. Ges. II. 33 (1893).

18. Abelia floribunda Decaisne apud Lemaire in $F l$. Serres, II. t. 5 (4) (1846).Decaisne in Rev. Hort. 1847, 301, t. 16. - Hooker in Bot. Mag. LXXIII. t. 4316 (1847).- - Lindley in Bot. Reg. XXXIII. t. 55 (1847).-Florist, II. 229, t. (1847).Garden, XIII. 468, t. 128 (1878). - Visschere in Rev. Hort. Belg. XXII. 157, t. (1897).

Vesalea floribunda Martens \& Galeotti in Bull. Acad. Brux. XI. 242 (1844).

Vesalea hirsuta Martens \& Galeotti, l. c. 242 (1844).

Abelia speciosa Decaisne apud Lemaire in Fl. Serres, II. text to t. 5 (1846).

Abelia hirsuta Walpers, Rep. VI. 3 (1848).

Linnaea floribunda A. Braun \& Vatke in Oesterr. Bot. Zeitschr. XXII. 291 (1872).

Mexi co: Sierra de San Felipe, C. G. Pringle (No. 4649), Cerro San Felipe, $E . W$. Nelson (No. 1053).

19. Abelia coriacea Hemsley, Diagn. Pl. Nov. Mex. 53 (1878-80); Bot. Biol. Am. Centr. II. 4, t. 36, fig. 1-5 (1881).

Linnaea coriacea Fritsch in Engler \& Prantl, Nat. Pfanzenfam. IV. 4, p. 166, fig. 55 (1891).

Mexico: San Louis Potosi, C. C. Parry \& E. Palmer (No. 299); Sierra de la Silla, C. G. Pringle (No. 2546).

Sect. II. ZABELIA, n. sect. (See p. 124).

Ser. 5. CORYMBOSAE Zabel in Mitt. Deutsch. Dendr. Ges. II. 33 (1893).

20. Abelia triflora R. Brown apud Wallich, Pl. As. Rar. I. 14, t. 15 (1830). Wight, Ill. II. 72, t. 121, C. (1850). - Lindley \& Paxton, Flow. Gard. III. 93, t. 91 (1853). - Lemaire in Jard. Fleur. III. tab. 319 (1853). - Briot in Rev. Hort. 1871, 510, t. - Hemsley in Garden, X. 58, t. 29 (1876). - Lauche, Deutsch. Dendr. 199, fig. 71 (1880).-Gard. Chron. ser. 2, XVI. 169, fig. 34 (1881).-Pucci in Bull. Soc. Tosc. Ort. XIX. 152, t. 5 (1894). 
Himalayas: Kumaon, Hooker \& Thomson, R. Strachey \& Winterbottom. In cultivation.

A. triflora, var, parvifolia Clarke in Hooker, Fl. Brit. Ind. III. 9 (1882).

Linnaea triflora, var. $\beta$ parvifolia Graebner \& Buchwald in Bot. Jahrb. XXIX. 135 (1900).

Western Himalayas: Jhelum Valley and Wuzaristan (Stewart ex Clarke).

21. Abelia angustifolia Bureau \& Franchet in Jour. de Bot. V. 47 (1891).

Linnaea angustifolia Graebner in Bot. Jahrb. XXIX. 135 (1900).

Szetch'uan (ex Bureau \& Franchet).

22. Abelia corymbosa Regel \& Schmalhausen in Act. Hort. Petrop. V. 608 (1878).

Linnaea corymbosa Graebner in Bot. Jahrb. XXIX. 136 (1900).

Turkestan (ex Maximowicz). Afghanistan: Kurrum Valley, Aitchison (No. 341),

The specimens from Afghanistan approach the preceding species; the sepals are lanceolate, one-nerved and only about half as long as the tube of the corolla, and the leaves are oblong to lanceolate.

Ser. 5. BIFLORAE Zabel in Mitt. Deutsch. Dendr. Ges. II. 33 (emend.) (1893)

23. Abelia biflora Turczaninow in Bull. Soc. Nat. Mosc. X. No. VII. 152 (Enum. Pl. Chin. Bor.) (1837). - Franchet in Nouv. Arch. Mus. Paris, sér. 2, VI. 29, t. 11 (Pl. David. I. 149) (1883). - Komarov in Act. Hort. Petrop. XXV. 515 (1907).

Abelia Davidii Hance in Jour. Bot. VI. 329 (1868), XIII. 132 (1875).

Abelia shikokiana Makino in Tokyo Bot. Mag. VI. 55 (nom. nudum) (1892); VII. 286 (quasi synon. of $A$. biflora) (1893).

Linnaea biflora Koehne, Deutsch. Dendr. 559 (1893).

Shansi: Wutai-shan, W. Purdom, 1909 (No. 297). Chili (ex Franchet and Maximowicz). Mandshuria, Maximowicz (Iter sec. 1860.) Japan: Shikoku, (ex Makino).

The occurrence of $A$. biflora in Shikoku, as reported by Makino, seems rather unlikely, and as long as I have seen no specimens of $A$. biflora from Japan, this determination seems doubtful to me.

24. Abelia Dielsii Rehder, n. comb.

Linnaea Dielsii Graebner in Bot. Jahrb. XXIX. 140 (1910).

Ch in a: Shensi, Tai-pai-shan, G. Giraldi (No. 1815 ex Diels).

25. Abelia Zanderi (Graebn.) Rehder. See p. 121.

26. Abelia onkocarpa, $\mathrm{n}$. comb.

Linnaea onkocarpa Graebner in Bot. Jahrb. XXIX. 140 (1901).

China: Shensi, Si-ku-tzui-shan, G. Giraldi (No. 1766 ex Diels).

27. Abelia umbellata (Graebn.) Rehder. See p. 122.

\section{HYBRIDS.}

Abelia chinensis $\times$ uniflora $=$ A. grandiflora Rehder in Bailey, Cycl. Am. Hort.

I. 1 (1900).

Abelia rupestris, var. grandiflora Rovelli apud André in Rev. Hort. 1886, 488.

Abelia rupestris hybrida Rovelli ex Schaedtler in Möller's Deutsch. GärtnerZeit. II. 223 (1887).

Abelia rupestris Hort. (rupestris $\times$ uniflora) Späth in Gartenfl. XLI. 113 t. 1366 (1892).

Abelia floribunda hybrida, A. multiflora hybrida, A. rupestris alba Hort. ex Zabel in Mitt. Deutsch. Dendr. Ges. II. 33 (as synon.) (1893). 
Linnaea (Abelia) Spaethiana (biflora $\times$ rupestris) Graebner in Bot. Jahrb. XXIX. 144 (1900).

Linnaea (Abelia) Perringiana (uniflora $\times$ chinensis) Graebner, l.c. 145 (1900).

This hybrid is not uncommon in cultivation under the name of $A$. rupestris; five of the specimens before me from different gardens are named thus, while one is named $A$. uniflora and one $A$. chinensis. They differ only slightly from each other and are all clearly intermediate between $A$. chinensis and $A$. uniflora, and exhibit not the slightest trace of an influence of $A$. biflora which, moreover, so far as I know, has never been in cultivation. The hybrid is hardier than either of its parents, which accounts for its wider distribution in our gardens. When and where it originated I have been unable to find out. The oldest specimen I have seen was collected at Kew in 1880 by G. Nicholson under the name of $A$. rupestris; it may be the form sent out by Veitch as $A$. rupestris grandiflora alba according to André. The form described by André as A. rupestris grandiflora originated in the nurseries of Rovelli Brothers at Pallanza, Italy. I have before me a specimen collected in Lavalle's Arboretum at Segrez in 1887 where it was, according to the label, received from Rovelli under that name.

\section{SPECIES TO BE EXCLUDED}

Abelia splendens Hort. ex K. Koch, Dendr. II. 1, p. 20 (as synon.) (1872) = Lonicera fragrantissima Lindley \& Paxton.

Abelia adenotricha Hance in Jour. Bot. IX. 132, 1871 (Linnaea adenotricha Graebner in Bot. Jahrb. XXIX. 144 [1900]) = Lonicera Elisae Franchet.

Though I have not seen Hance's specimen, I accept, after comparing his description with Lonicera Elisae, as correct Franchet's suggestion (Plant. David. I. 152) that Abelia adenotricha is probably the same as Lonicera Elisae. All the characters even including measurements agree with those of $L$. Elisae, and the peculiar inflorescence which seemed so strange to Maximowicz (Mél. Biol. XII. 479) may be explained, if one imagines that Hance had a specimen like the upper part of Franchet's figure of $L$. Elisae; Hance may have easily taken the solitary peduncle as originating between the two branchlets. Place and time of collection of the two species also agree. As there is no other plant among the undoubtedly complete set of David's plants sent to Paris and determined by Franchet, which corresponds to $A$. adenotricha, hardly any doubt seems to be left that Hance's name must be referred as a synonym to $L$. Elisae.

LONICERA L.

Subgen. I. CHAMAECERASUS L.

Sect. I. ISOXYLOSTEUM Rehd.

Subsect. Microstruat Rehd.

Lonicera tubuliflora Rehder, n. sp.

Frutex erectus 1-4 m. altus ramulis gracilibus, hornotinis plerumque purpurascentibus breviter et dense villosis interdum glandulis paucis interspersis, annotinis pallide flavido-brunneis, vetustioribus griseis cortice fibroso. Gemmae parvae, griseo-flavescentes, 4 perulis exteriori- 
bus. Folia decidua, oblonga v. oblongo-obovata, obtusa, basi rotundata v. late cuneata, 6-10 $\mathrm{mm}$. longa et 2-3 mm. lata, glabra, supra coeruleo-viridia, subtus glaucescentia, utrinsecus costis 3 v. 4 supra impressis, subtus conspicuis; petioli glabri, $0.5 \mathrm{~mm}$. longi. Flores bini in pedunculis glabris petiolos aequantibus v. paullo superantibus erectis v. suberectis axillaribus in parte media v. superiore ramulorum, fragrantissimi; bracteae anguste oblongae, glabrae, 2.5-4 $\mathrm{mm}$. longae, calycem duplo superantes; bracteolae in cupulam vix lobatam ovariis dimidio breviorem connatae; ovaria ovoidea, libera, $1.5 \mathrm{~mm}$. longa, bilocularia; dentes calycis ovati v. oblongo-ovati, obtusi, inaequales, dimidia ovaria aequantes, sparse glanduloso-ciliati; corolla tubulosa, alba, extus glabra, tubo cylindrico fauce leviter constricto, $8-10 \mathrm{~mm}$. longo, $2 \mathrm{~mm}$. diam., intus supra insertionem staminum pilis longis infra pilis brevibus sparsis instructo, lobis patentibus suborbicularibus, $1.5 \mathrm{~mm}$. longis; filamenta brevissima, tubo paullo supra medium affixa, antherae oblongae, connectivo loculos paullo superante; stylus glaber tubo dimidio brevior. Fructus desiderantur.

Western Szech'uan: thickets in sunny places near Mou-kongting, alt. 2700 m., June 1908 (No. I883).

Lonicera tubuliflora seems most nearly related to $L$. syringantha Maximowicz, which is easily distinguished by its much wider lilac corolla with the tube only three times as long as the limb and not constricted at the mouth, by the 3-celled ovaries, the longer lanceolate calyx-teeth, the higher cupula and the larger often acute leaves.

Lonicera thibetica Bureau \& Franchet in Jour. de Bot. V. 48 (1891).

Western Szech'uan: uplands around Tachien-lu, alt. $2500 \mathrm{~m}$., July 28, 1908 (No. 827, in part); around Sungpan, abundant, alt. 2400-3000 m., August 1910 (No. 827, in part).

Lonicera syringantha Maximowicz in Bull. Acad. Sci. St. Pétersbourg, XXIV. 49; in Mél. Biol. X. 77 (1877).

Western Szech'uan: upland thickets, Ta p'ao shan, northeast of Tachien-lu, alt. 3600 m., July 6, 1908 (No. 1872); Pan-lan-shan, west of Kuan-Hsien, alt. 3600 m., June 24, 1908 (No. 1873).

Wilson's specimens differ slightly from the type in their shorter corolla tube, 4-5 $\mathrm{mm}$. long, and in their narrower and smaller leaves broadly cuneate at the base and usually in threes. One of the branches shows the young leaves beneath and the flower buds furnished with a very slight floccose pubescence which soon disappears. 
Sect. 2. ISIKA DC.

Subsect. PURPURASCENTES Rehd.

Lonicera shensiensis Rehder in Fedde, Rep. Sp. Nov. VI. 269 (1909).

Lonicera trichopoda, var. shensiensis Rehder in Rep. Missouri Bot. Gard. XIV. 57 (1903).

Western Hupeh: woodlands, Hsing-shan Hsien, alt. 1600-1800 m., May and July 1907 (No. I867).

Lonicera trichogyne Rehder, n. sp.

Frutex erectus circiter metralis ramulis junioribus sparse villosis, vetustioribus pallide griseis v. brunneo-griseis cortice fibroso. Gemmae parvae, perulis 8-10 exterioribus persistentibus. Folia decidua, oblonga v. obovata-oblonga, v. inferiora minoraque ovalia v. obovata, obtusa v. obtusiuscula, basi sensim in petiolum pubescentem, 2-4 $\mathrm{mm}$. longum attenuata, 2-6 $\mathrm{cm}$. longa et 13-23 mm. lata, supra laete viridia et glabra pilis paucis marginem ciliatam versus exceptis, subtus cinerascenti-viridia et villosa praesertim in venis, utrinsecus 5-6costata. Flores bini in pedunculis gracilibus sparse villosis, $6-10 \mathrm{~mm}$. longis axillaribus in parte inferiore ramulorum; bracteae lineari-lanceolatae, acuminatae, ciliatae et extus pubescentes, calycis dentes paullo superantes; bracteolae nullae; ovaria fere tota connata, $2 \mathrm{~mm}$. longa, villosa uti margo calycis brevis obsolete dentata; corolla gracilis, tubulosa, supra basin leviter ventricosa, $14 \mathrm{~mm}$. longa, lobis suborbicularibus suberectis; antherae lobos paullo superantes; stylus exsertus. Fructus desiderantur.

Western Szech'uan: Wa-ssu country, Wên-chuan Hsien, among rocks, alt. $2300 \mathrm{~m}$., July 1908 (No. 1866, young fruits only); e a stern Szech'u an, Tchen-keou, R. P. Farges (flowers).

Lonicera trichogyne is closely allied to $L$. stenosiphon Franchet from Yunnan, which differs in its smaller narrow, oblong, acute leaves, pubescent on both sides, longer glabrous peduncles, larger distinctly toothed calyx and shorter stamens with the anthers reaching only to the base of the limb. The description of the flowers given above is taken from Farges' specimens, which differ from Wilson's No. 1866 in the leaves being only 12-18 mm. long.

Lonicera serpyllifolia Rehder in Rep. Missouri Bot. Gard. XIV. 58, t. 1, f. 1-5 (1903).

Western Szech'uan: Tachien-lu, woodlands, alt. 2400-3000 m., September 1910 (No. 4I40). 
Wilson's specimen differs from the type in the nearly subulate bracts and the larger leaves and possibly does not belong here, but without flowers it is difficult to place.

\section{Lonicera flavipes Rehder, n. sp.}

Frutex erectus 1-2 m. altus ramulis gracilibus, junioribus glabris et plerumque purpurascentibus, annotinis pallide brunneis et nitidulis, vetustioribus griseis cortice fibroso. Gemmae perulis exterioribus circa 8 ovatis obtusis ciliatis et pubescentibus. Folia decidua, obovata v. obovato-oblonga v. inferiora ovalia, obtusa, basi in petiolum brevem fere glabrum flavum 2-3 $\mathrm{mm}$. longum attenuata, supra flavoviridia et sparse et adpresse pubescentia, subtus pallide flavo-viridia, pilis laxe adpressis obtecta, 2-4.5 $\mathrm{cm}$. longa et 10-18 $\mathrm{mm}$. lata, utrinsecus 5-6 costis conspicuis uti costa media flavidis. Flores bini in pedunculis gracilibus glabris $2-2.5 \mathrm{~cm}$. longis axillaribus in parte inferiore ramulorum; bracteae lanceolatae, foliaceae, sparse ciliatae, calycis dentes superantes; bracteolae nullae; ovaria supra medium connata, margine calycis obsolete dentata trientem ovariorum aequante; corolla tubulosa, gracilis, supra basin leviter gibbosa, $11 \mathrm{~mm}$. longa, albida, extus supra medium sparse patentim pilosa, intus pilis paucis longis infra insertionem staminum, lobis orbiculari-ovatis 2 $\mathrm{mm}$. longis suberectis; filamenta paullo supra medium tubum affixa, glabra, $3 \mathrm{~mm}$. longa, antherae $2 \mathrm{~mm}$. longae, lobos medios attingentes; stylus exsertus, $15 \mathrm{~mm}$. longus, pilis longis patentibus insuructus basi et apice exceptis. Fructus desiderantur.

Western Hupeh: Wên-tsao Mts., Hsing-shan Hsien, woodlands, alt. 2300 m., June 5, 1908 (No. r868).

Most nearly related to $L$. tangutica Maxim., which differs chiefly in the smaller and narrower acute leaves nearly glabrous on the under surface or only sparingly pubescent on the veins, in petioles and veins not being yellow, in the subulate bracts not exceeding the ovaries, in the corolla glabrous on the outside, and in the style being glabrous or only furnished with a few hairs near the base.

Lonicera tangutica Maximowicz in Bull. Acad. Sci. St. Pétersbourg, XXIV. 48 (1877). - Wolf in Gartenfl. XL. 580, fig. 104-105 (1891).

Western Szech'uan: Wa-ssu country, Wên-chuan Hsien, common, alt. 1800-2400 m., August 1908 (No. 83r); Chin-ting-shan, alt. 18002400 m., May and September 1908 (No. 83 $\mathrm{r}^{\mathrm{b}}$, in part); Wa-shan, woods, alt. 2400-3300 m., August 1908 (No. 950).

Lonicera szechuanica Batalin in Act. Hort. Petrop. XIV. 172 (1895).

L. tangutica, var. glabra Batalin, $l$. c. 
Western Szech'uan: woodlands, southeast of Tachien-lu, alt. 1800-2400 m., June and September 1908 (No. 83 ${ }^{\circ}$ ).

\section{Lonicera Schneideriana Rehder, n. sp.}

Frutex erectus metralis ramulis gracilibus, junioribus glabris, annotinis pallide flavido-griseis cortice fibroso. Gemmae perulis 6-8 exterioribus glabris pallide griseis. Folia decidua, obovata v. oblongoobovata, apice rotundata v. obtusiuscula, basi sensim in petiolum gracilem glabrum $2 \mathrm{~mm}$. longum attenuata, $1-2.5 \mathrm{~cm}$. longa et 4-7 $\mathrm{mm}$. lata, utrinque glabra, supra flavo-viridia, subtus glaucescentia. Flores bini in pedunculis gracilibus pendulis glabris circa $2.5 \mathrm{~cm}$. longis axillaribus in parte inferiore ramulorum; bracteae subulatae, acutae, vix ovaria tota $\mathrm{v}$. fere tota connata dimidia aequantes; bracteolae nullae; calyx campanulatus, dentibus inaequalibus saepe obsoletis, dimidia ovaria aequans, circa $1 \mathrm{~mm}$. longus; corolla tubulosa, basi leviter gibbosa, $9 \mathrm{~mm}$. longa, flava, extus glabra, intus pubescens, lobis suborbicularibus erectis, $2 \mathrm{~mm}$. longis; filamenta glabra, paullo infra partem trientem superiorem tubi affixa, $2.5 \mathrm{~mm}$. longa, antherae oblongae, $2 \mathrm{~mm}$. longae, paullo limbum superantes; stylus exsertus, pubescens, $12 \mathrm{~mm}$. longus. Bacca subglobosa, rubra, circa $7 \mathrm{~mm}$. diam., calyce persistente coronata; semina pluria, ovoidea, leviter compressa, flavescenti-alba, $2 \mathrm{~mm}$. longa, testa laevi.

Western Szech'uan: Mupin, woodlands, alt. 1600-2400 m., June and August 1908 (No. 83 Iª, type); alt. 2300 m., June 1908 (Nos. I859, I860); alt. 2400-2700 m., September 1910 (No. 42I4); around Sungpan, upland, rocky places, alt. 3000-3500 m., August 1910 (No. 4023).

Lonicera Schneideriana resembles in foliage $L$. szechuanica Batalin, which differs in the stamens being shorter than the corolla-lobes, in the longer bracts and in the glabrous style. Lonicera shensiensis Rehder is distinguished chiefly by the shorter stamens and the presence of bractlets, while $L$. serpyllifolia Rehder differs in the smaller somewhat hairy leaves, the ovate bracts and shorter peduncles. No. 1859 differs from the type in the generally oblanceolate leaves, $2-3 \mathrm{~cm}$. long. No. 1860 is still more different but hardly sufficiently different to be made the type of another species; it has a shorter distinctly gibbous corolla, shorter calyx and glabrous style, but otherwise, particularly in the foliage, the short bracts and in the slightly exserted anthers, it agrees with the type.

I take pleasure in associating with this species the name of Mr. C. K. Schneider, whose Illustriertes Handbuch der Laubholzkunde contains many valuable contributions to the knowledge of Chinese trees and shrubs.

Lonicera saccata Rehder in Sargent, Trees and Shrubs, I. 39, pl. 20 (1902). 
Western Hupeh: Chang-lo Hsien, woodlands, alt. 1600-1800 m., May and July 1907 (No. 32); Hsing-shan Hsien, woods, abundant, alt. 1800-2700 m., May 1907 (No. I863); rocks in woods, not common, alt. 2300 m., May 10, 1907 (No. I864); Fang Hsien, woodlands, alt. 1500-2100 m., June 1910 (No. 4007). Western Szech'uan: Chinting-shan, thickets, alt. 1800-2400 m., May and July 1908 (No. 83 $\mathrm{I}^{\mathrm{b}}$, in part); Ta-hsing-ling, Ching-chi Hsien, thickets, alt. 2200-2700 m. (No. I86I); thickets, summit of Nin-tou-shan, west of Kuan Hsien, alt. $2700 \mathrm{~m}$. (No. 1862); Pan-lan-shan, west of Kuan Hsien, thickets, alt. 2100-2700 m., August 1910 (No. 4038).

Wilson's No. 1861 and 1862 from Western Szech'uan differ from the type in their shorter less saccate corolla and also in the less pubescent and generally broader leaves, those of 1861 resembling f. Wilsonii.

Lonicera saccata, f. Wilsonii Rehder in Rep. Missouri Bot. Gard. XIV. 60 (1903).

Western Hupeh: summit of Wên-tsao Mt., Hsing-shan Hsien, thickets, not common, alt. 2700 m., May 1907 (No. I865).

The specimen differs from the typical f. Wilsonii in its smaller leaves, generally only $1.5 \mathrm{~cm}$. long.

Lonicera longa Rehder in Rep. Missouri Bot. Gard. XIV. 61, pl. 1, fig. 6 (1903).

Western Hupeh: Fang Hsien, woodlands, alt. 13001800 m., August 1907 (No. I83); alt. 2400-2700 m., September 1910 (No. 44I5).

One of Wilson's specimens with unripe fruits fortunately had a single pair of apparently belated flowers, which gives me the opportunity to add here the description of the flowers, hitherto unknown. Flowers on slender upright peduncles sparingly pilose or glabrous; bracts linear-lanceolate exceeding the minute and indistinctly toothed calyx; bractlets wanting; corolla tubular, 10-12 mm. long, slightly gibbous above the base, glabrous outside, sparingly hairy inside below the stamens; lobes orbicular-ovate, about $1.5 \mathrm{~mm}$. long, upright; stamens inserted somewhat above the middle, filaments very short, anthers oblong, $3 \mathrm{~mm}$. long, not reaching the base of the limb; style exserted, very sparingly pilose below the middle.

Subsect. Pileatae Rehd.

Lonicera gynochlamydea Hemsley in Jour. Linn. Soc. XXIII. 362 (1888).

Western Hupeh: north and south of Ichang, common, side of streams, alt. 600-1400 m., May and August 1907 (No. 266).

Lonicera ligustrina Wallich in Roxburgh, Fl. Ind. ed. 2, II. 179 (1824). - Wight, Icon. Pl. Ind. Or. III. 14, pl. 1025; Ill. Ind. Bot. II. 
72, pl. 121, B. 3 (1850). - Fritsch in Engler \& Prantl, Nat. Pflanzenfam. IV. 4, 167, f. 57, F-I (1891).

Western Szech'uan: Mupin, watercourses, alt. $1200 \mathrm{~m}$., October 1908 (No. Ir35, in part). Western Hupeh: no locality, May 1900 (Veitch Exped. No. 471).

Lonicera pileata Oliver in Hooker's Icon. XVI. pt. 1585 (1887). Gard. Chron. ser. 3, XXXV. 243, pl. 101 (1904).

Western Hupeh: Ichang, water-courses, alt. 30-900 m., April and May 1907 (No. 1858). Western Szech'uan: Tachien-lu, watercourses, alt. 1200-1800 m., June and August 1908 (No. 833, in part); Washan, watercourses, alt. 1600 m., June 1908 (No. 833, in part); Mupin, side of streams, alt. 1800 m., June and August 1908 (No. 877); Kuan-Hsien, roadside, alt. 900 m., June 1908 (No. Ir35, in part).

Subsect. Chlamydocarpi Jaub. \& Spach.

Lonicera Ferdinandii Franchet, var. leycesterioides Zabel in Mitt. Deutsch. Dendr. Ges. XVII. 189 (1908).

Lonicera leycesterioides Graebner in Bot. Jahrb. XXXVI. Beibl. LXXXII. 100 (1905).

Western Szech'uan: thickets, Nin-tou-shan, west of Kuan Hsien, alt. 3000 m., June 1908 (No. r874); Mong-kong-ting, June 1908 (No. 1876); northeast of Sungpan, thickets, alt. 2400 m., August 1910 (No. 4479).

The chief difference between this variety and the type lies in the generally larger, more oblong-ovate leaves, their softer pubescence, the narrower bracts and the less setose corolla.

As I have stated before (Rhodora, XI. 210), the section Vesicariae proposed by Komarov and adopted by me in my Synopsis of the genus must be united with the Chlamydocarpi; the cupula is not adnate to the base of the calyx, only firmly adhering by matted hairs, and splits at maturity disclosing the bright red berries.

\section{Subsect. Fragrantissimae Rehd.}

Lonicera Standishii Carrière, var. lancifolia Rehder in Rep. Missouri Bot. Gard. XIV. 82 (1903).

Lonicera pseudoproterantha Pampanini in Nuov. Giorn. Bot. Ital. n. ser. XVII. 723, fig. 18 (1910).

Western Hupeh: Ichang, common up to $1200 \mathrm{~m}$., April and June 1907 (No. I4). 
Lonicera mucronata Rehder in Rep. Missouri Bot. Gard. XIV. 83, t. 2, fig. 8-9 (1903); in Sargent, Trees and Shrubs, II. 47, t. 122 (1907).

Western Hupeh: Hsing-shan Hsien, cliffs, alt. 300-600 m., March 26 and May 24, 1907 (No. 8or).

\section{Subsect. BRACTEATAe Hook. f. \& Thoms.}

Lonicera mitis Rehder in Sargent, Trees and Shrubs, II. 50 (1907); in Fedde, Rep. Sp. Nov. VI. 271 (1909).

Western Szech'uan: southeast of Tachien-lu, uplands, alt. 3600 $3900 \mathrm{~m}$. (No. 4I39).

As the mature leaves and fruits of this species have not been described, their description may be given here: Leaves oblong or obovate-oblong, acutish or obtuse and mucronulate, broadly cuneate at the base, 2-3 $\mathrm{cm}$. long and 8-15 $\mathrm{mm}$. broad, minutely velvety on both sides, margin revolute, dark green above, netted with paler veins, paler green beneath and reticulate; petioles 1-2 cm. long, puberulous. Fruits on very short peduncles 1-3 mm. long, ovoid, longer than the bracts deciduous at maturity, bluish black, usually with 3-8 seeds; seeds irregularly triangular-oblong, lustrous, dark brown, $4.5 \mathrm{~mm}$. long.

This and $L$. cyanocarpa Franchet are so far the only species known of the Bracteatae which have blue or bluish black fruits. Lonicera cyanocarpa, of which the flowers are unknown, is apparently closely related, but easily distinguished by the narrower and somewhat larger coriaceous leaves, setulose-ciliate on the margin and by the ovate-lanceolate acuminate and ciliate bracts. When ir fruit $L$. mitis looks in general appearance so much like $L$. coerulea that it might be taken for that species if it were not for the distinct berries.

Lonicera setifera Franchet, var. trullifera Rehder, n. var.

Folia quam in typo majora, 6-12 $\mathrm{cm}$. longa petiolis basi valde dilatatis oppositis connatis et cupulam oblongam subtus manifeste trinervem interdum plus quam $1 \mathrm{~cm}$. latam et $2.5 \mathrm{~cm}$. longam formantibus.

Western Szech'uan: near summit of Nin-tou-shan, west of Kuan Hsien, alt. 2700 m., June 20, 1908 (No. 902 ${ }^{\mathrm{a}}$ ).

The leaves of this variety have the same coarse dentation, a very unusual feature in the genus, as those of the type from Yunnan, but are nearly twice as large. As long as the type and this variety are known from a single collection each, it cannot be decided whether the peculiar dilated petioles are an essential feature of the variety or may also occur on vigorous branches of the type.

\section{Lonicera subdentata Rehder, n. sp.}

Frutex erectus 1-3 m. altus ramulis glabris, annotinis pallide brunneis v. griseo-brunneis cortice laevi. Gemmae perulis exterioribus 2 acutis circa $5 \mathrm{~mm}$. longis. Folia decidua, oblongo-ovata v. ellipticooblonga, acuminata, basi late cuneata v. rotundata, integra v. utrinque 1-3 dentibus latis obtusisque, 5-9 $\mathrm{cm}$. longa et $2.5-4 \mathrm{~cm}$. lata, 
papyracea, supra obscure viridia pilis setosis adpressis paucis conspersa, subtus glaucescentia et hirsuta, utrinsecus 5-6-costata; petioli sparse setosi, $4 \mathrm{~mm}$. longi. Flores desiderantur. Baccae ovoideae, rubrae, sparse setosae in pedunculis $5 \mathrm{~mm}$. longis setosis et sparse glandulosis e basi innovationum orientibus; bracteae oblongo-ovatae, acutae, $1 \mathrm{~cm}$. longae, setoso-ciliatae, ceterum glabrae; calycis dentes ovati, inaequales, plerumque obtusi, $2-3 \mathrm{~mm}$. longi, setoso-ciliati; semina late oblonga, 5-6 mm. longa, compressa, flavescentia, testa laevi.

Western Szech'uan: southeast of Tachien-lu, woods, alt. 24002700 m, July 1908 (No. 902).

Lonicera subdentata seems most nearly related to the preceding species and to L. scabrida Franchet, but both these species have the branchlets furnished with reflexed setose hairs. Lonicera praecox Rehder, which is somewhat similar in foliage and in its glabrous branchlets, is easily distinguished by the winter-buds having several outer roundish scales and by the glabrous ovaries.

Lonicera hispida Pallas apud Roemer \& Schultes, Syst. V. 258 (1819).

Western Szech'uan: Pan-lan-shan, west of Kuan Hsien, alt. 2700-3000 m., June 24, 1908 (No. 1855); Ta-p'ao-shan, northeast of Tachien-lu, thickets, alt. 2700-3000 m., June 8, 1908 (No. 1853); Sungpan, grass land, alt. 2700-3000 m., August 1910 (No. 40ro).

None of these specimens represent the type of the species; No. 1855 resembles in the shape of the leaves, bracts and corolla $L$. chaetocarpa, but the leaves are nearly and the ovaries quite glabrous, while No. 1853 consists of two slightly differing specimens resembling in foliage and shape of corolla somewhat $L$. vaccinioides Rehder, but the leaves, particularly on the upper surface, are sparingly hairy, the corolla is larger and the ovaries densely glandular in one specimen and glandular and setose in the other.

Lonicera chaetocarpa Rehder, n. sp.

Lonicera hispida var. chaetocarpa Batalin apud Rehder in Rep. Missouri Bot. Gard. XIV. 94 (1903).

Western Szech'uan: Wa-shan, thickets, alt. 2400 m., July and October 1908 (No. 942); upland thicket around Tachien-lu, alt. 24003400 m., October 1908 (Nos. I077, 1854); Mupin, upland thickets, alt. 3000 m., October 1908 (No. Io77²), thickets, alt. 2100-2500 m., June and October 1908 (No. 1857); upland thickets, alt. $2700 \mathrm{~m}$., October 1910 (No. 4230); Wa-shan, cliffs, alt. 3000 m., July 1903 (Veitch Exped. No. 3754).

In habit and in its general appearance this species differs markedly from typical $\boldsymbol{L}$. hispida Pallas, of which it has been considered a variety. It is easily distinguished by the setose and glandular ovary, the larger and wider corolla prominently saccate 
at the base, the larger bracts, the larger leaves, hirsute on both sides and grayish green beneath, and by the hirsute pubescence of the whole plant.

Lonicera praecox Rehder, n. comb.

Caprifolium praecox Kuntze, Rev. Gen. Plant. I. 274 (1891).

Lonicera infundibulum Franchet in Jour. de Bot. X. 315 (1896).

Western Hupeh: Chang-yang Hsien, roadsides, alt.,1000-1500 m., April 1907 (No. 1856); Fang Hsien, rare, alt. 1600-1700 m., June 15, 1910 (No. 4006).

\section{Subsect. ALPigenae Rehd.}

Lonicera mupinensis Rehder, n. sp.

Frutex erectus, 1.5-6 m. altus ramulis junioribus sparse stipitatoglandulosis mox glabrescentibus v. fere glabris, ramis vetustioribus cinereis fibrosis. Gemmae circa $1 \mathrm{~cm}$. longae, perulis 8-10 exterioribus scariosis lanceolatis acuminatis, interioribus accrescentibus foliaceis omnibus sub anthesi erectis longe persistentibus instructae. Folia elliptico-oblonga $\mathrm{v}$. oblonga v. obovato-oblonga, acuminata, basi late cuneata, inferiora interdum rotundata, 6-12 cm. longa et 2.5-5.5 lata, dense molliter ciliata, supra laete viridia, initio sparse pilosa, demum fere glabra, subtus pallide viridia, ad venas venulasque pilosa, interdum glabrescentia, basin versus plerumque sparse glandulosa, utrinsecus 6-7-costata; petioli 5-8 mm. longi, sparse v. interdum densius glandulosi et sparse breviter pilosi, demum glabrescentia. Flores bini pedunculis stipitato-glandulosis v. fere glabris apice incrassatis 3.5$5 \mathrm{~cm}$. longis insidentes; bracteae subulatae, glanduloso-ciliatae, ovaria disjuncta duplo v. fere duplo superantes; bracteolae liberae v. anteriora basi tantum connata, glanduloso-ciliatae, ovatae, obtusae, ovariis dimidio breviores v. et oblongae ovariis triplo breviores; corolla bilabiata, $1.5 \mathrm{~cm}$. longa, extus glabra, atropurpurea, tubus manifeste gibbosus, intus dense pilosus, limbo paullo brevior, labium superius 4-lobum lobis ovatis rotundatis brevibus; stamina limbo paullo breviora filamentis basi pilosa excepta glabris quam antherae anguste oblongae longioribus; stylus stamina subaequans, infra medium pilosus. Baccae rubrae, subglobosae, 8-10 $\mathrm{mm}$. diam., seminibus plerumque 2-3, ovoideis leviter compressis flavido-albidis laevibus nitidulis.

Western Szech'uan: Mupin, thickets, alt. 1800-2400 m., June and October 1908 (No. 86r, in part); alt. 2700-3000 m., October 1910 (No. 4225); near Wa-shan, woodlands and thickets, alt. 2100-2700 m., June and September 15, 1908 (No. 86r, in part), alt. 2700-3000 m., July 1903 (Veitch Exped. No. 3741). 
This species forms with $L$. Webbiana Wallich, $L$. heterophylla Decaisne, $L$. heteroloba Batalin, $L$. tatsienensis Franchet, and $L$. perulata Rehder a group of very closely related species. The first differs chiefly in the glandular pubescence, pale flowers and broader not acuminate partly reflexed bud-scales; $L$. heterophylla in the quite glabrous foliage; $L$. heteroloba and $L$. tatsienensis differ in the smaller reflexed bud-scales, in the smaller leaves being pilose on the whole under surface and usually rounded at the base and in the shorter bracts; $L$. perulata is easily distinguished by its numerous obtuse bud-scales. From all these species $L$. mupinensis differs in its upright lanceolate acuminate bud-scales; in the shape of the leaves and in the amount of pubescence it seems rather variable.

Lonicera tatsienensis Franchet in Jour. de Bot. X. 313 (1896).

Western Szech'uan: Pan-lan-shan, west of Kuan Hsien, alt. 2100-3000 m., June 1908 (No. I870), August 1910 (No. 4037), October 1910 (No. 43I9).

One of Wilson's specimens under No. 1870 has part of the leaves deeply and irregularly lobed, but agrees otherwise with the type; another specimen under the same number and No. 4319 differ in their nearly glabrous and broader leaves.

Lonicera Hemsleyana Rehder in Rep. Missouri Bot. Gard. XIV. 112 (1903).

Western Hupeh: Hsing-shan Hsien, cliffs, rare, alt. 1800 m., May 1907 (No. I87I).

No. 1871 differs from the type in the leaves being loosely pubescent beneath and sometimes rounded at the base, in the shorter cupule and in the style being glabrous near the apex.

Subsect. RHODANTHAE Maxim.

Lonicera modesta Rehder in Sargent, Trees and Shrubs, II. 49 (1907).

Kiangsi: Kuling, alt. 1200 m., July 2, 1907 (Nos. I658, I658²).

Lonicera modesta, var. lushanensis Rehder, n. var.

A typo recedit foliis ovalibus v. oblongis, glabris v. fere glabris.

Kiangsi: Kuling, Lushan Mountains, side of streams, common, alt. $1200 \mathrm{~m}$. (Nos. I657, type, I655, I656).

This variety seems rather variable in pubescence and shape of the leaves; No. 1657 has the young branchlets villous and the midrib on both surfaces of the leaves and also the peduncles and bractlets pubescent; the leaves are oval to elliptic. No. 1655 is nearly glabrous except a few hairs on the petioles, the peduncles and on the branchlets just below the nodes; the leaves are elliptic to ovate-lanceolate and often acute. No. 1656 has the pubescence of the preceding specimen, but the leaves are narrowly elliptic or oblong and obtuse or acutish.

Lonicera retusa Franchet in Jour. de Bot. X. 313 (1896). - Rehder in Sargent, Trees and Shrubs, II. 49, t. 123 (1907). 
West ern Szech'u a n: near Mong-kong Ting, thickets, side of river, alt. 2400-3000 m., June 1908 (No. 1877).

No. 1877 differs from the type in its generally narrowly elliptic, obtuse or acutish, not retuse, leaves.

Lonicera nervosa Maximowicz in Bull. Acad. Sci. St. Pétersbourg, XXIV. 39 (1877).

Western Szech'uan: Ta-p'ao-shan, northeast of Tachien-lu, woods, alt. 2700-3600 m., July 1908 (No. r88o); northeast of Sungpan, woodlands, alt. 2700-3000 m., August 1910 (No. 40Ir).

Lonicera lanceolata Wallich in Roxburgh,Fl.Ind.ed.2, II.177 (1824).

Western Szech'uan: Wa-shan, woods, common, alt. 2100-2700 m., June and September 1908 (No. 927); Mupin, woods, alt. 2300 m., September 1908 (No. 927 ); Wa-ssu country, Wên-chuan Hsien, woods, alt. 2200-2300 m., June and September 1908 (No. I88I). Western Hupeh: Fang Hsien, woodlands, alt. 2200 m., September 1907 (No. 304).

No. 304 from Hupeh differs from the type in its glabrous leaves.

\section{Sect. 3. COELOXYLOSTEUM}

\section{Subsect. ochranthaE Rehd.}

Lonicera Koehneana Rehder in Sargent, Trees and Shrubs, I. 41, t. 21 (1902).

Western Hupeh: north and south of Ichang, thickets, common, alt. 1200-1800 m., May and July 1907 (No. 93): Chang-lo Hsien, thickets, alt. 1500-2100 m., May and July 1907 (No. 93 ${ }^{\mathrm{a}}$ ); Hsing-shan Hsien, woodlands, alt. 1500-2300 m., June and July 1907 (No. 98), June 12, 1910 (No. 4478); Fang Hsien, thickets, alt. 1800-2300 m., August 1907 (No. I98).

Lonicera Maackii Maximowicz, var. podocarpa Franchet apud Rehder in Rep. Missouri Bot. Gard. XIV. 141 (1903).

Western Hupeh: north and south of Ichang, thickets, common, alt. 900-1500 m., May 5 and August 1907 (No. 194); Hsing-shan Hsien, thickets, alt. 900 m., October 1907 (No. 4I2); South Wushan, thickets, alt. 1200 m., October 1907 (No. 457). Chekiang: Ningpo, D. Macgregor.

Lonicera deflexicalyx Batalin in Act. Hort. Petrop. XII. 173 (1892). Western Szech'uan: Wa-ssu country, Wên-chuan Hsien, alt. 
2400-2700 m., July and August 1908 (No. 808): near Wa-shan, thickets, alt. 2700 m., September 14, 1908 (No. 808); Mupin, thickets, alt. 2400-3000 m., June and September 1908 (No. 856, in part), October 1910 (No. 4293); Nin-tou-shan, west of Kuan Hsien, thickets, alt. 2500 m., June 1907 (No. 1852); Tachien-lu, thickets, alt. 2400-3000 m., October 1910 (No. 4I79).

Lonicera trichosantha Bureau \& Franchet in Jour. de Bot. V. 48 (1891).

Lonicera ovalis Batalin in Act. Hort. Petrop. XIV. 170 (1895).

Western Szech'uan: around Tachien-lu, alt. 2400-3000 m., June and September 1908 (Nos. 856 ${ }^{\mathrm{a}}$, 856 $^{\mathrm{b}}$ ), October 1910 (No. 856, in part).

No. $856^{\mathrm{b}}$ differs in the leaves being slightly pubescent on both surfaces and more densely on the midrib beneath.

Lonicera prostrata Rehder in Sargent, Trees and Shrubs, II. 50 (1907); in Fedde, Rep. Sp. Nov. VI. 275 (1909).

Western Szech'uan: near Sungpan Ting (type locality), alt. 3000-3500 m., August and October 1910 (No. 4044); Mupin, prostrate over loamy bank, alt. 2700-3000 m., October 1910 (No. 4227).

\section{Sect. 4. NINTOOA DC.}

\section{Subsect. BREVIFLORAE Rehd.}

Lonicera crassifolia Batalin in Act. Hort. Petrop. XII. 172 (1892).

Western Szech'uan: near Wa-shan, thickets, alt. $1200 \mathrm{~m}$., June 1908 (No. 1878).

Lonicera alseuosmoides Graebner in Bot. Jahrb. XXIX. 594 (1901).

Western Szech'uan: near Wa-shan, thickets, alt. 1500-1800 m., September 18, 1908 (No. 938); Chito near Tachien-lu, thickets, very rare, alt. 3000 m., July 26, 1908 (No. I882).

Lonicera Henryi Hemsley in Jour. Linn. Soc. XXIII. 363 (1888).

Western Hupeh: north and south of Ichang, thickets, abundant, alt. 1200-1800 m., July and September 1907 (No. 254, in part); Changlo Hsien, common, alt. 1200-1800 m., July 1907 (No. 254, in part); Fang Hsien, common, alt. 1200-1400 m., July 1907 (No. 254, in part); South Wushan, alt. 1200-1800 m., July 1907 (No. 254, in part); Patung Hsien, thickets, abundant, alt. 1200-1400 m., June 1907 (No. 254, in part); Hsing-shan Hsien, common, alt. 1200-1800 m., July 
1907 (No. 254, in part). Western Szech'uan: near Tachien-lu, thickets, alt. 2300 m., June 1908 (No. 1879, in part).

Lonicera Henryi, var. subcoriacea Rehder, n. var.

A typo recedit foliis subcoriaceis nitidulis majoribus ovato-oblongis 6-10 $\mathrm{cm}$. longis et $2.5-4 \mathrm{~cm}$. latis omnino glabris costa media supra strigillosa excepta. Ramuli in parte superiore dense strigillosi, in inferiore plerumque glabri; petioli dense strigillosi, pedunculi hirti, bracteae bracteolaeque ciliatae; flores $2 \mathrm{~cm}$. longi, tubo quam limbus longiore.

Western Szech'uan: Yung-ching Hsien, thickets, alt. 1800-2100 m., September 1910 (No. 4097); Wa-ssu country, Wên-chuan Hsien, alt. 1200-1800 m., July 1908 (No. 1879, in part); near Mong-kong Ting, thickets, alt. 1500-1800 m., June 18, 1908 (No. I879, in part).

In the shape of the foliage this variety resembles very much $L$. fuchsioides Hemsley, but that species is easily distinguished by the perfectly glabrous branchlets and inflorescence, by the larger flowers and by the looser and more elongated terminal inflorescence. No. 1879 forms a transition to the type, as the leaves of the lateral flowering branchlets are narrower, often slightly ciliate, and pubescent on the midrib beneath.

\section{Subsect. LONGIFLORAE Rehd.}

Lonicera similis Hemsley, var. Delavayi Rehder n. var.

Lonicera Delavayi Franchet in Jour. de Bot. X. 301 (1896).

Western Hupeh: Fang Hsien, thickets, alt. 1800 m., October 1907 (No. 589); July 1907 (No. 1869). W estern Szech'u an: Hungya Hsien, sandstone boulders," alt. 300-1200 m., June and September 1908 (No. 936).

Lonicera Delavayi differs from $L$. similis only in the absence of the pubescence, and as many specimens are intermediate between the two in the amount of pubescence, it seems more natural to treat $L$. Delavayi only as a glabrous or glabrescent variety of $L$. similis.

Lonicera japonica Thunberg, Fl. Jap. 89 (1784).

Western Hupeh: around Ichang, common, alt. 300-600 m., May and July 1907 (No. 1875). Chekiang: Ningpo, D. Macgregor.

\section{Subgen. 2. PERICLYMENUM L.}

Subsect. PHEnIanthi Rehd.

Lonicera subaequalis Rehder in Rep. Missouri Bot. Gard. XIV. 172 (1903). 
Western Szech'uan: Wa-shan, thickets, alt. 1500-1800 m., June 1908 (No. 940).

The fruits, which have not yet been described, are subglobose, about $7 \mathrm{~mm}$. in diameter and red; the seeds ellipsoid, about $2 \mathrm{~mm}$. long, whitish, with finely reticulate testa.

\section{Subsect. EUCAPRIFOLIA Spach.}

Lonicera tragophylla Hemsley in Jour. Linn. Soc. XXIII. 367 (1888). - Rehder in Sargent, Trees and Shrubs, I. 91, t. 40 (1903).

Western Hupeh: north and south of Ichang, thickets, common, alt. 1200-1800 m., August 1907 (No. 346, in part); Patung Hsien, woodlands, alt. 1100-1800 m., June 1908 (No. 346, in part); Hsingshan Hsien, woodlands, alt. 900-1800 m., June 1908 (No. 346, in part).

Here may be added some further notes on Chinese Loniceras, based on other than Wilson's recently collected material.

Lonicera pileata Oliver, var. linearis Rehder, n. var.

Folia linearia v. lineari-oblonga, obtusa, membranacea, pallide viridia, 1-2.5 cm. longa et 2-4 mm. lata; corolla extus fere glabra, modice gibbosa; stamina paullo exserta.

Yunnan: Szemeo, alt. 1600 m., A. Henry (No. 11800).

A very distinct variety, chiefly differing from the type in the very narrow, membranaceous, light green leaves.

Lonicera fragrantissima Lindley \& Paxton, Flow. Gard. III. 75, fig. 268 (1852).

Kwangtung: Ningpo, D. Macgregor.

If this specimen has been really collected from a wild plant, as it appears to have been, it would settle the question of its habitat, as $L$. fragrantissima has been known only as a cultivated plant.

Lonicera montigena Rehder, n. sp.

Frutex erectus, circa 5 decim. altus, ramulis junioribus breviter pubescentibus glandulis et pilis setosis reflexis interspersis. Gemmae acutae, 5-6 mm. longae, pallide brunneae, perulis 2 exterioribus. Folia oblonga, acuta, basi late cuneata, supra pilis laxe adpressis obtecta, subtus densius pilosa, utrinque insuper minute pubescentia glandulosaque, $1.5 \mathrm{~cm}$. longa et $0.5 \mathrm{~cm}$. lata (nondum perfecte evoluta); petioli minute pubescentes, glandulosi, sparse hirsuti. Flores bini in pedunculis brevibus nutantibus minute pubescentibus glandulosisque e basi innovationum orientibus; bracteae orbiculari-ovatae, obtusae, $12 \mathrm{~mm}$. longae, minute pubescentes glandulosaeque marginem versus pilis longioribus instructae; bracteolae nullae; ovaria ovoidea, libera, $3 \mathrm{~mm}$. alta, calyce cupuliformi dimidia ovaria vix aequante ut apex ovariorum glandulis stipitatis et pilis paucis setosis instructo; corolla infundibuliformis, $23 \mathrm{~mm}$. longa, tubo gracili basi saccato supra medium ampliato, lobis patentibus, late ovatis, $6 \mathrm{~mm}$. longis, extus dense pubescens et glandulosa, intus infra medium pilis sparsis brevibus praedita; stamina paullo infra medium affixa, filamentis $3 \mathrm{~mm}$. longis, glabris, antheris quam filamenta paullo longioribus, oblongis, limbo paullo brevioribus; stylus glaber, corollam subaequans. Fructus desiderantur.

Szech'uan: alt. 4000 m., June 1904 (Veitch Exped. No. 375, in part). 
Allied to L. hispida Pallas, which differs chiefly in the larger winter-buds, in the absence of the glandular pubescence on the leaves, bracts and branchlets, in the larger corolla only sparingly hairy outside, in the filaments being longer than the anthers and in the pilose style. Lonicera nubigena Rehder, distributed under the same number, is easily distinguished by its much shorter corolla, the tube being only $1 \mathrm{~cm}$. long, the anthers not exceeding the mouth and the style only half as long as the tube: it is a lower and more densely branched shrub and more alpine in its general aspect than $L$. montigena.

Lonicera Tatarinovii Maximowicz in Mém. Acad. Sci. St. Pétersbourg, IX. 138 (Prim. Fl. Amur.) (1859).

Lonicera leptantha Rehder in Fedde, Rep. Sp. Nov. VI. 274 (1909).

Chili: Weichang, 1910, W. Purdom (No. 82). Shenking: no locality, June 27, 1906, F. N. Meyer (No. 42). Cor ea: Quelpaert, Hallaisan, alt. 1800-2000 m., June and July 1907, U. Faurie (Nos. 1843, 1844).

The form from Corea which I recently described as $L$. leptantha cannot be specifically separated from $L$. Tatarinovii, as a comparison with good flowering material recently received from Chili shows; it is hardly different enough to be separated as a variety. The ovaries of the species are usually two-thirds connate, occasionally only at the base, and the bractlets are connate into a cupula, not distinct, as stated in my Synopsis of the genus.

Lonicera affinis Hooker \& Arnott, Bot. Voy. Beechey, 264 (1841).

Fokien: without locality, April to June 1905, S. T. Dunn (Herb. Hongkong Bot. Gard. No. 2777).

Lonicera affinis, var. pubescens Maximowicz in Bull. Acad. Sci. St. Pétersbourg XXIV. 37; in Mél. Biol. X. 58 (1877).

Fokien: without locality, April to June 1905, S. T. Dunn (Herb. Hongkong Bot. Gard. No. 2778).

\section{DIERVILLA L.}

Diervilla japonica De Candolle, Prodr. IV. 330 (1830).

D. floribunda Forbes \& Hemsley in Jour. Linn. Soc. XXIII. 369 (not Siebold \& Zuccarini) (1888).

Western Hupeh: north and south of Ichang, thickets, alt. 9002300 m., May, June and December 1907 (No. 762); Hsing-shan Hsien, thickets, alt. 900-1800 m., May and June 1907 (Nos. 2916, 2917, 2018). 



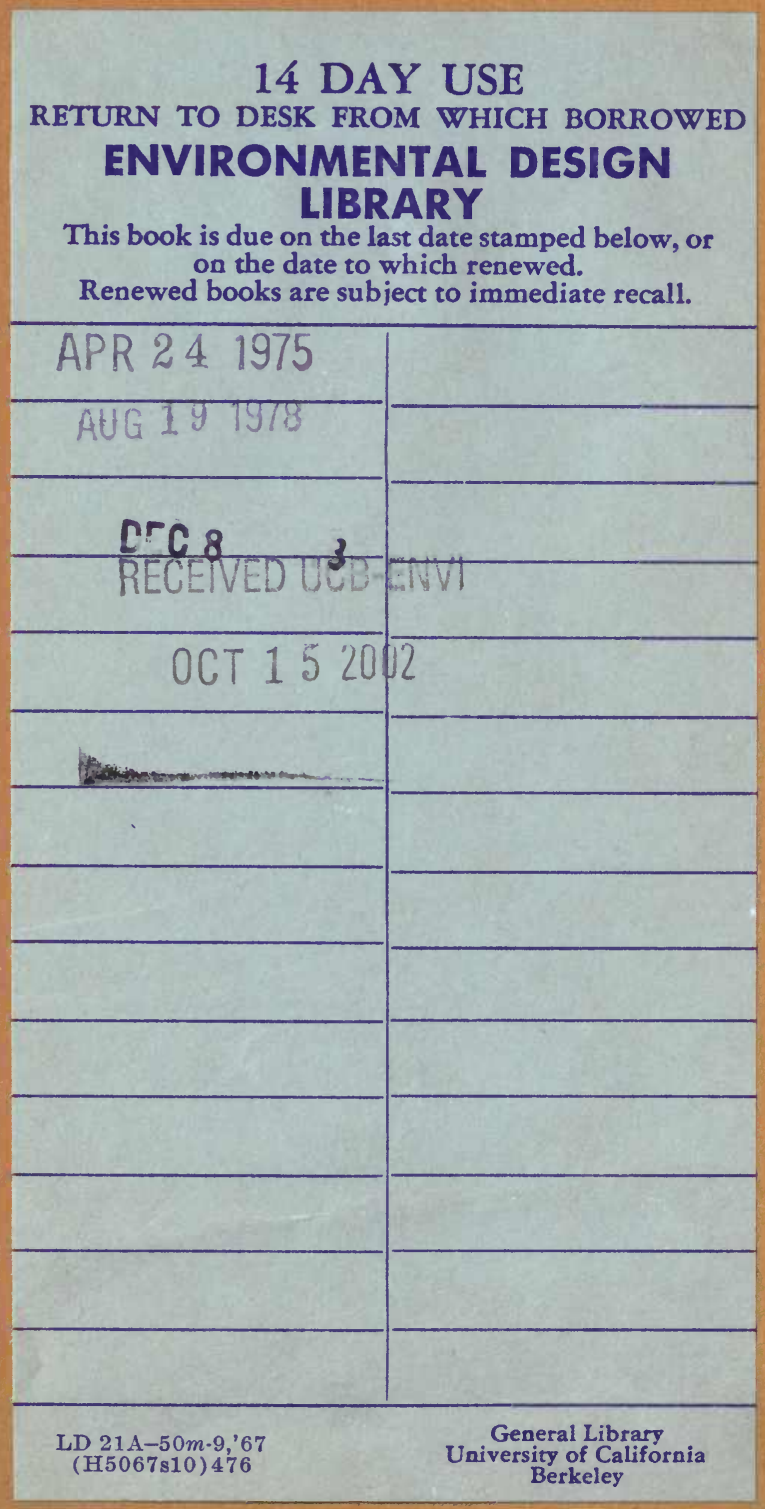


mini

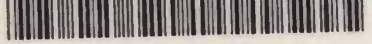
C037568978
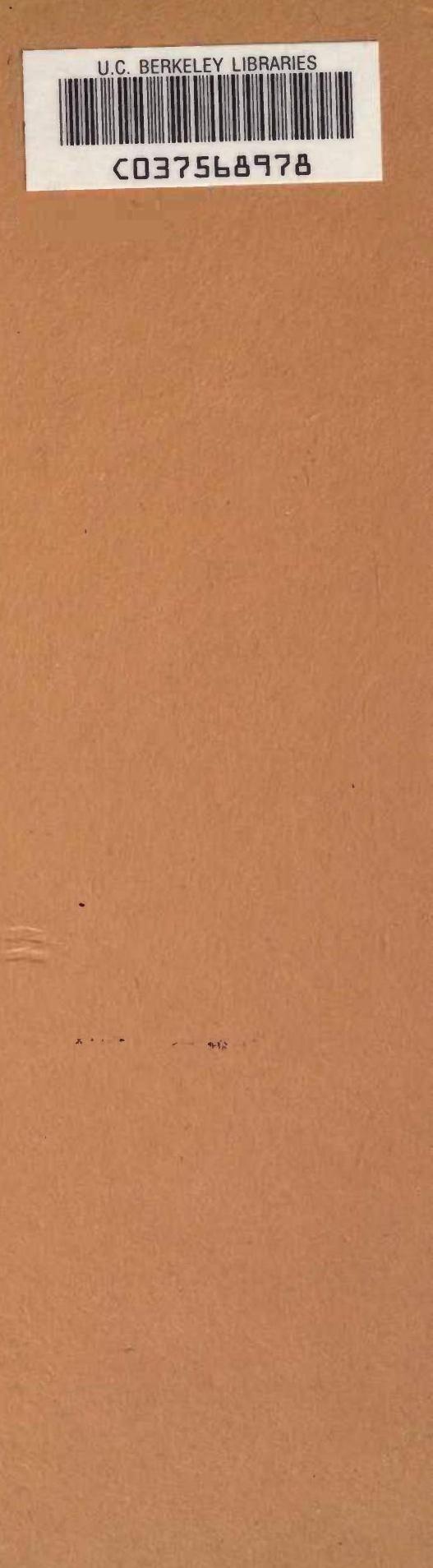

... $+x_{i} \rightarrow$

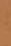


